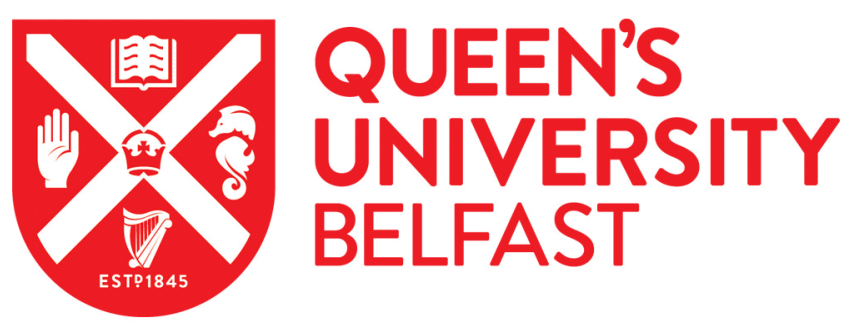

\title{
The Nineteenth Century Law of the Sea and the British Abolition of the Slave Trade
}

Allain, J. (2008). The Nineteenth Century Law of the Sea and the British Abolition of the Slave Trade. British Yearbook of International Law, 78(1), 342-388. https://doi.org/10.1093/bybil/78.1.342

Published in:

British Yearbook of International Law

Document Version:

Early version, also known as pre-print

Queen's University Belfast - Research Portal:

Link to publication record in Queen's University Belfast Research Portal

\section{General rights}

Copyright for the publications made accessible via the Queen's University Belfast Research Portal is retained by the author(s) and / or other copyright owners and it is a condition of accessing these publications that users recognise and abide by the legal requirements associated with these rights.

Take down policy

The Research Portal is Queen's institutional repository that provides access to Queen's research output. Every effort has been made to ensure that content in the Research Portal does not infringe any person's rights, or applicable UK laws. If you discover content in the Research Portal that you believe breaches copyright or violates any law, please contact openaccess@qub.ac.uk. 

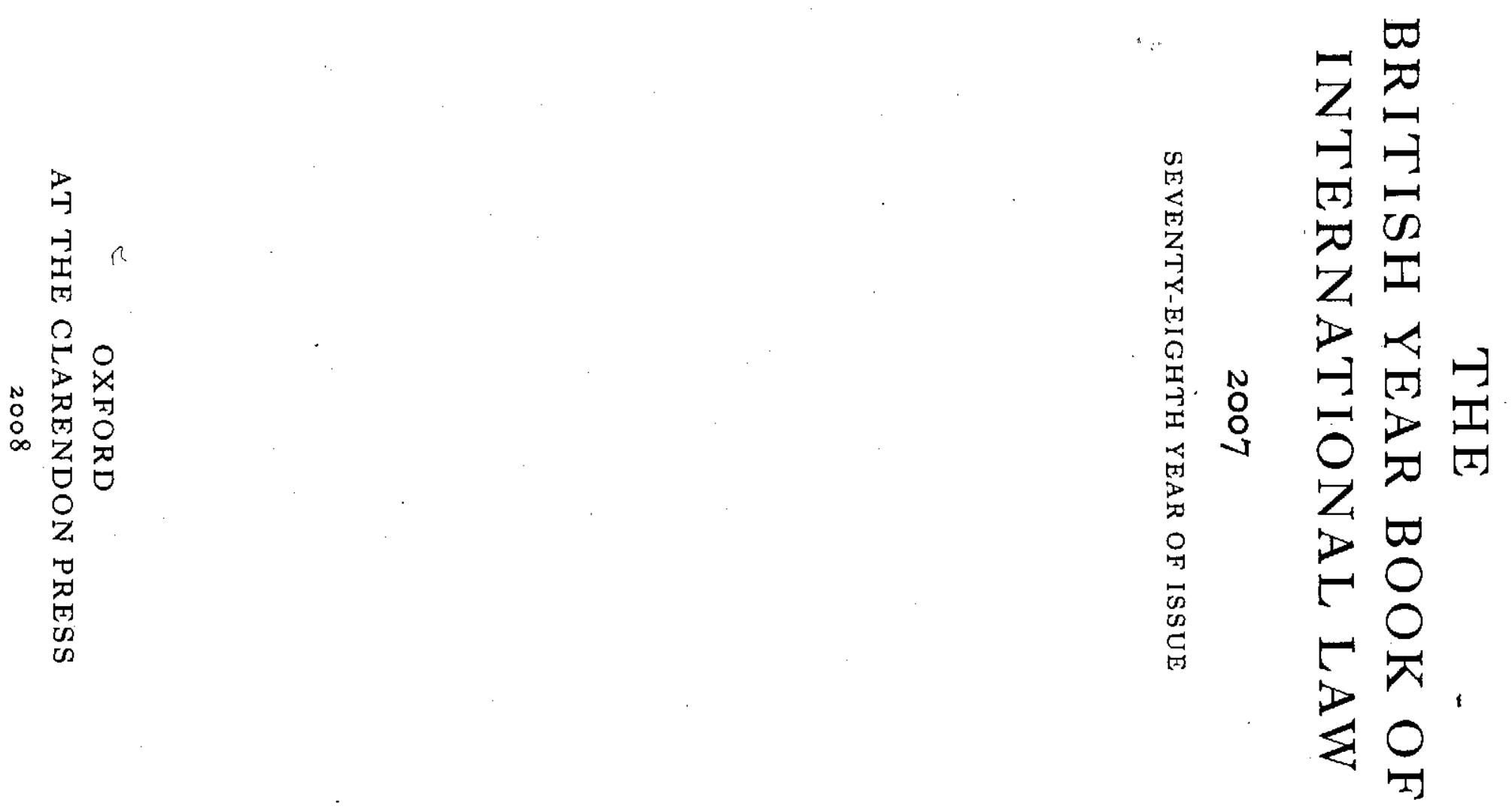


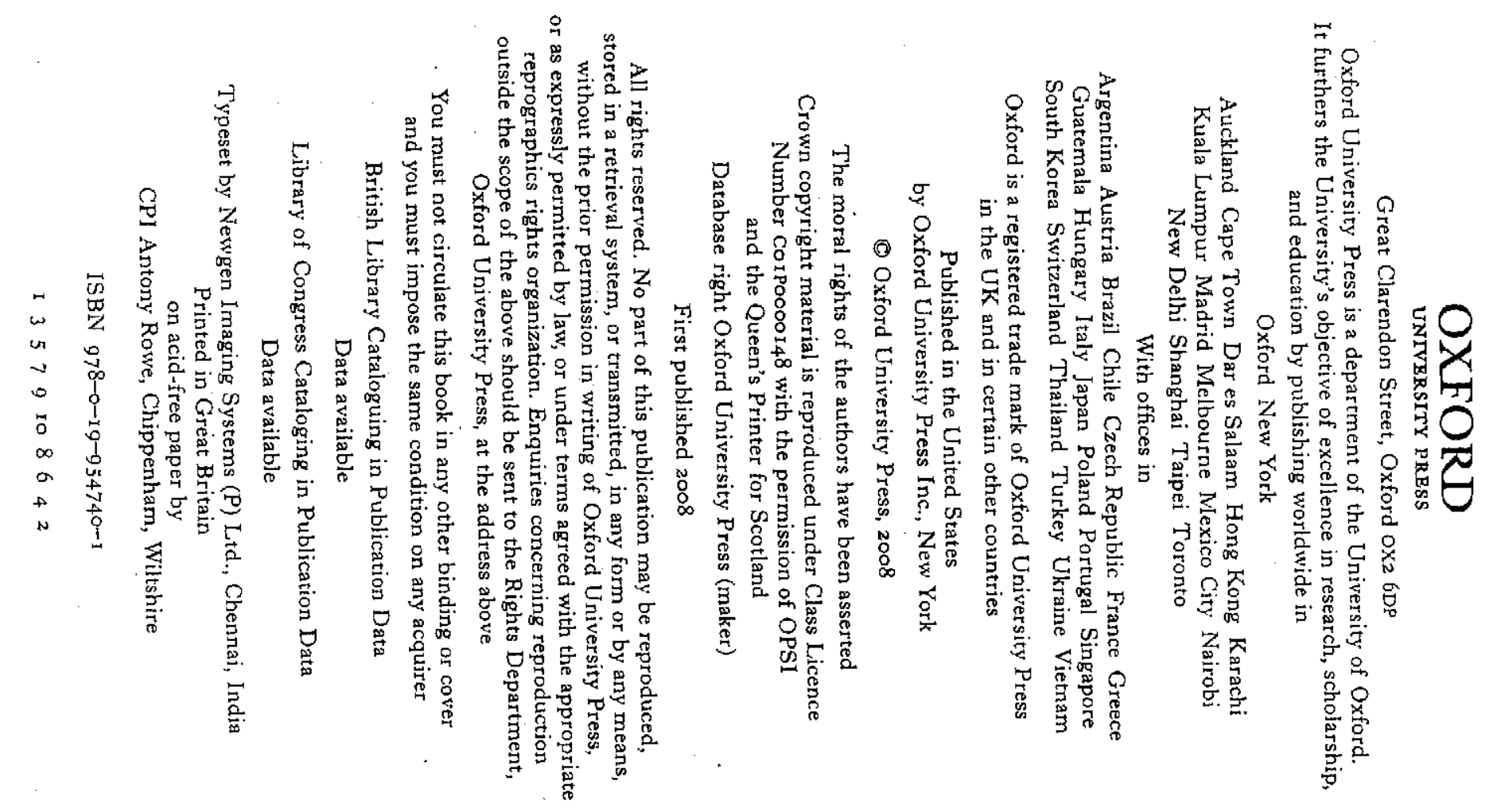




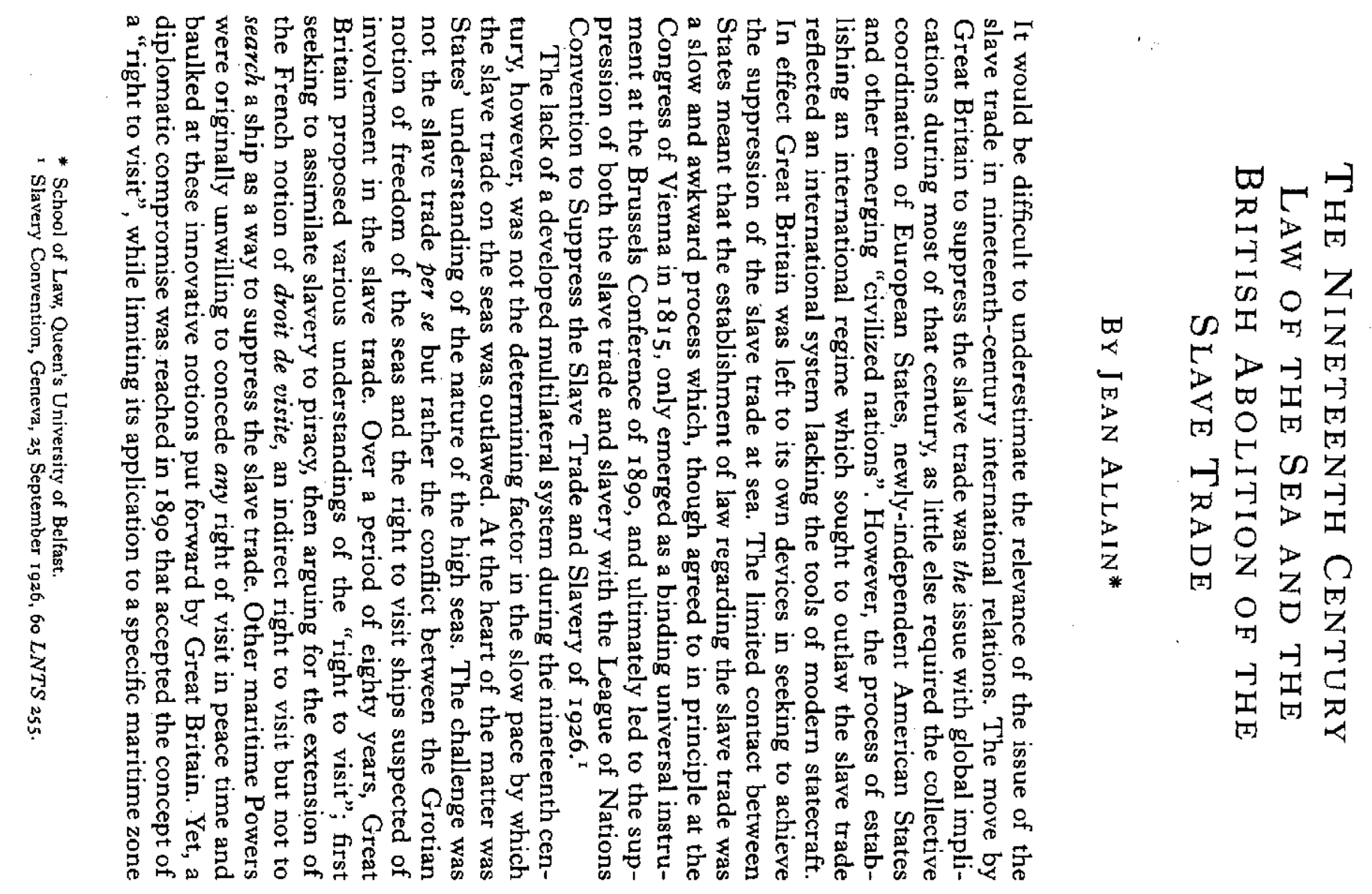




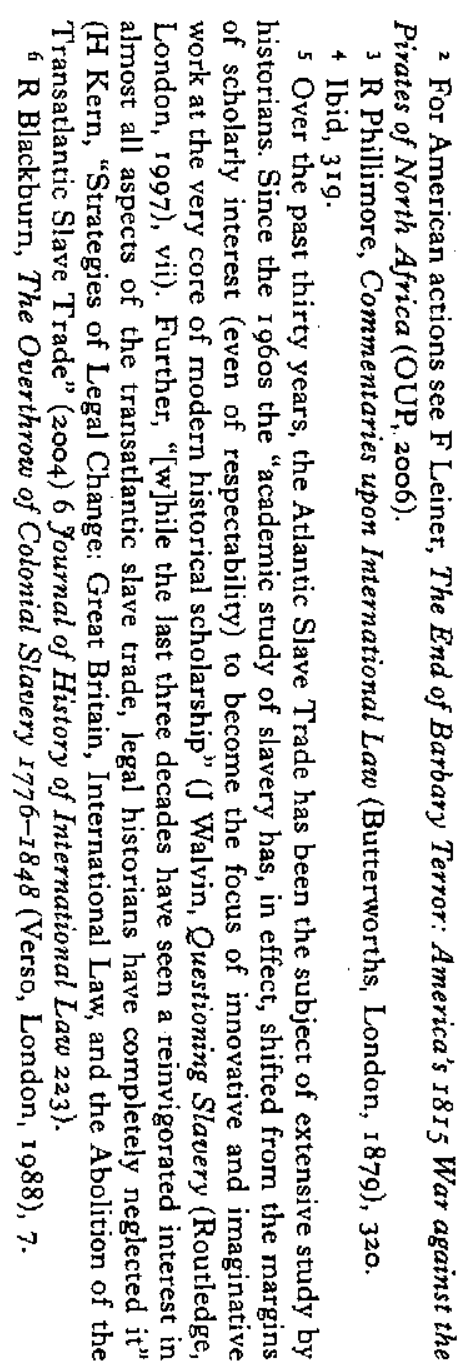

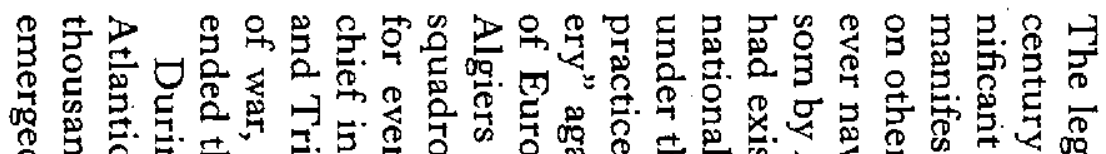

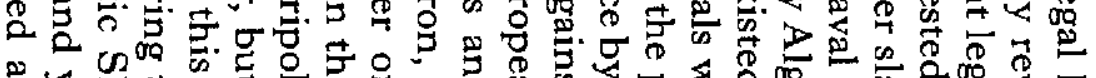

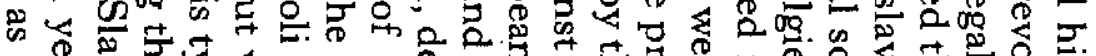
w 品 \&

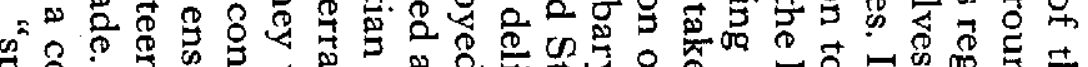

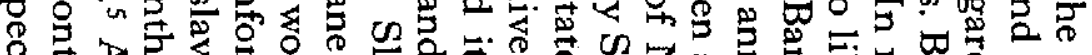
.

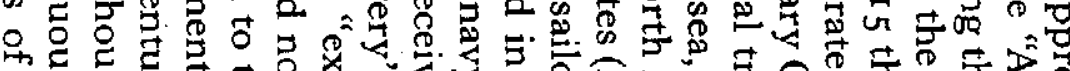

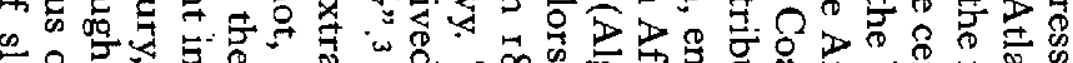

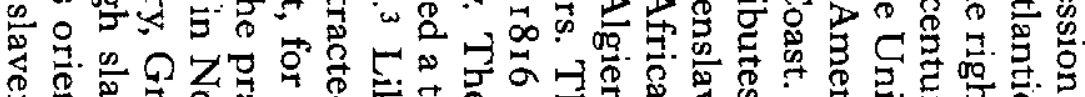

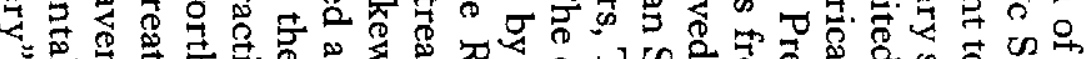

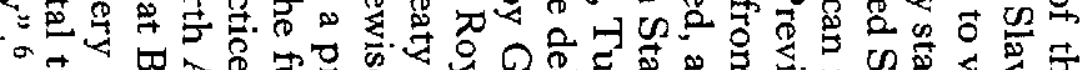

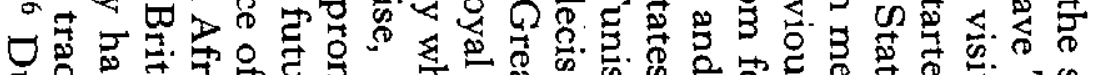

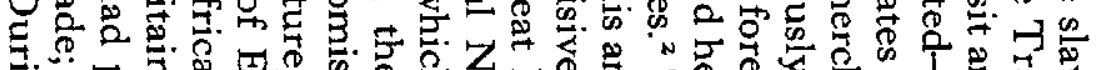
宊 F告记

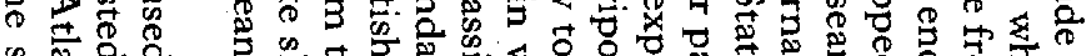
舟:

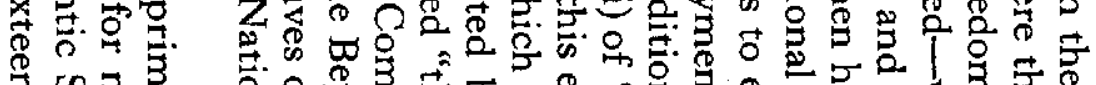

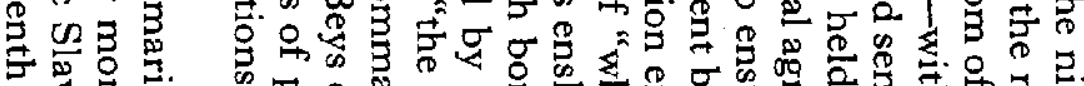

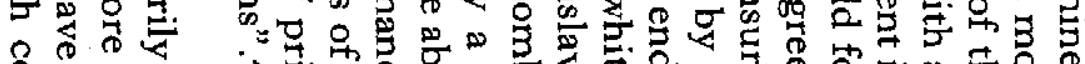

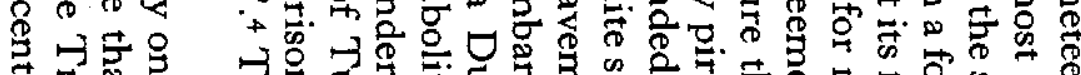

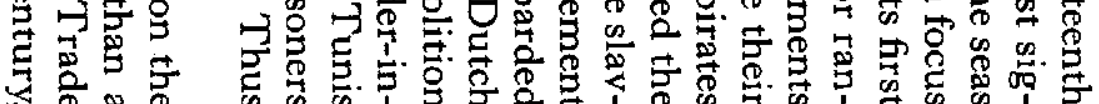

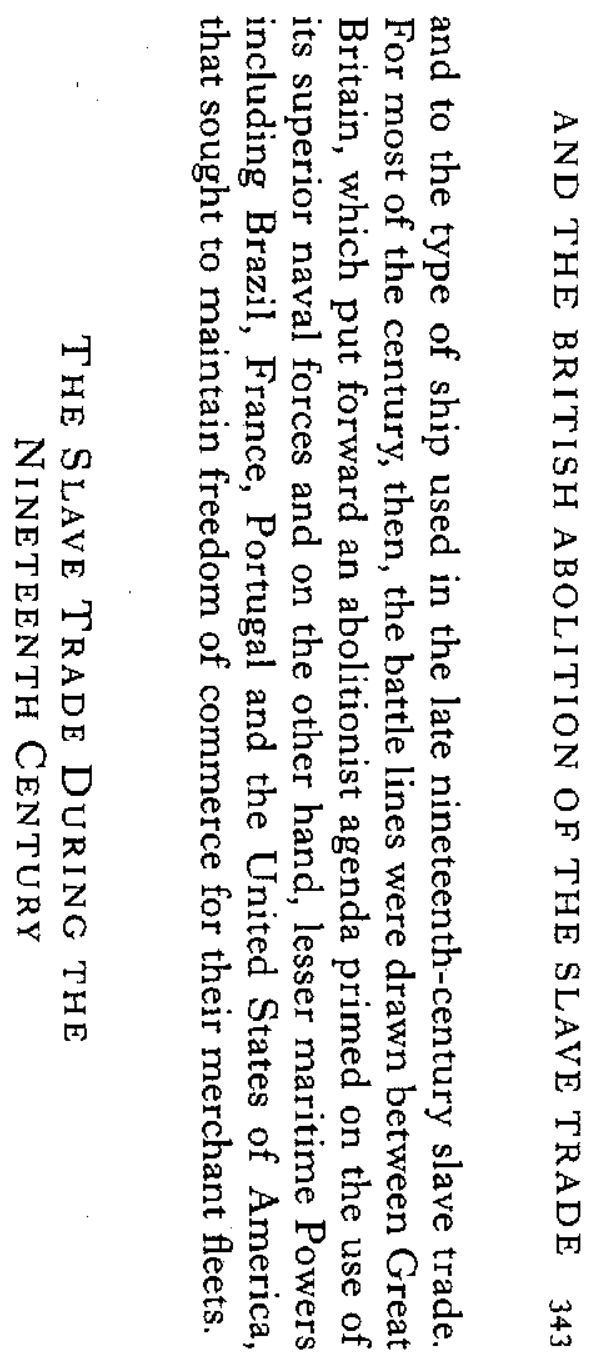




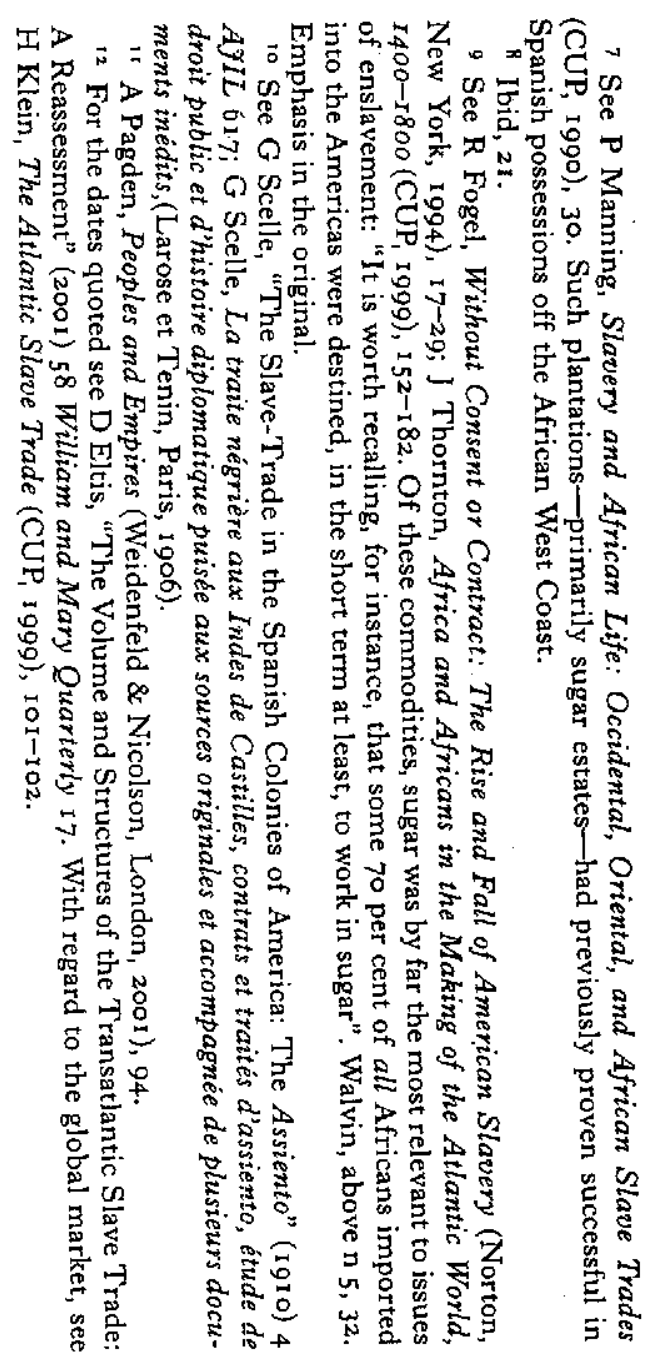

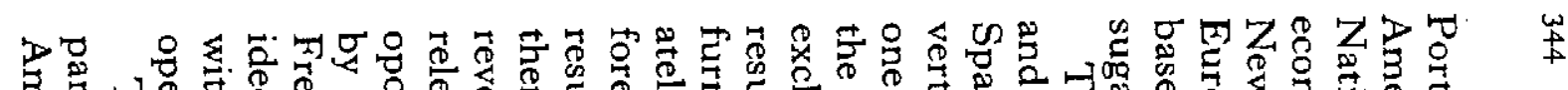

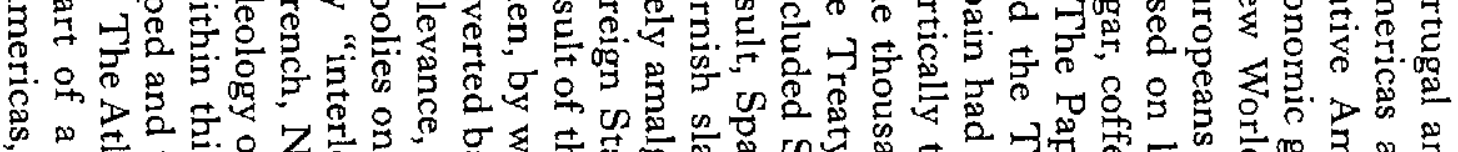

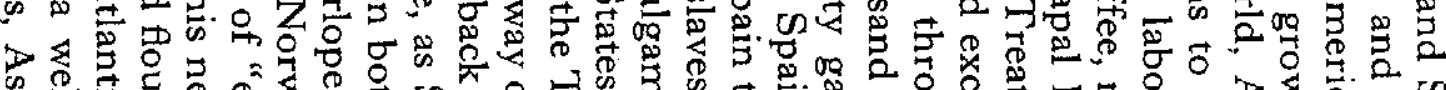

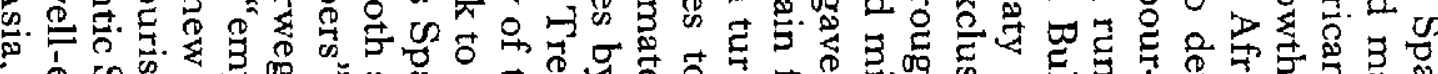

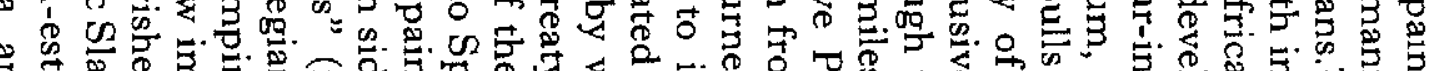

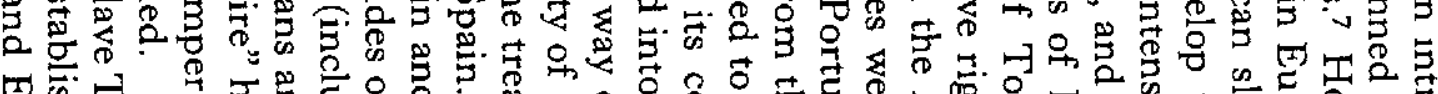
(大)

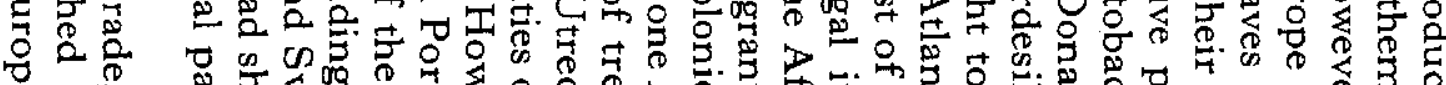

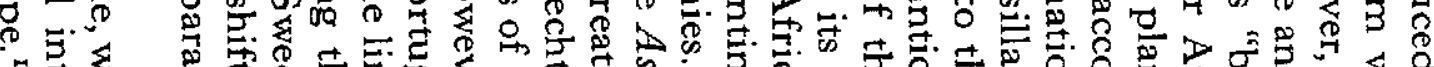

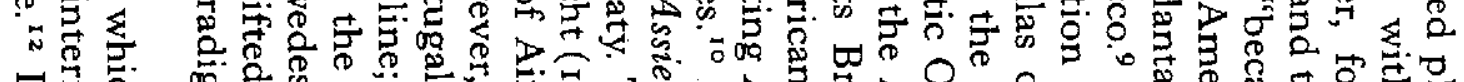

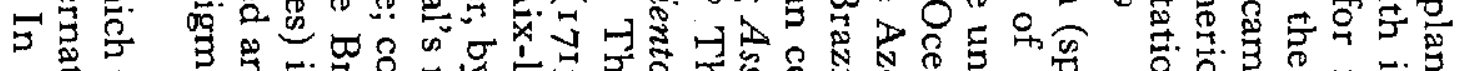

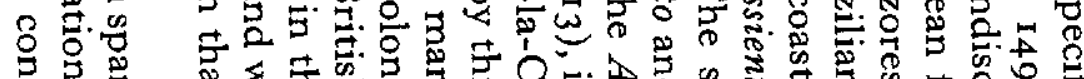

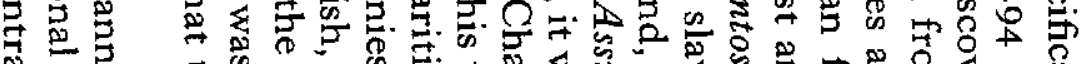

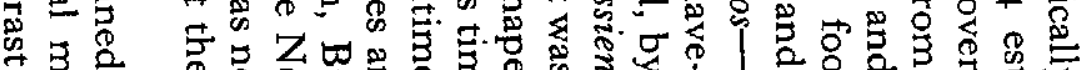

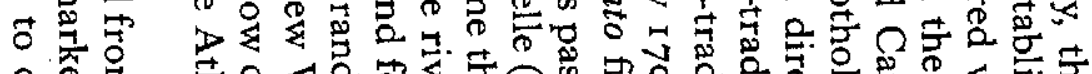

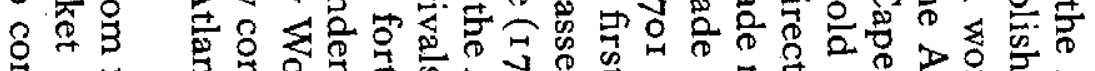

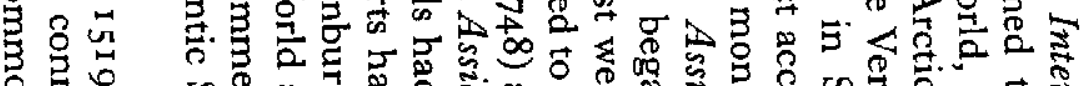

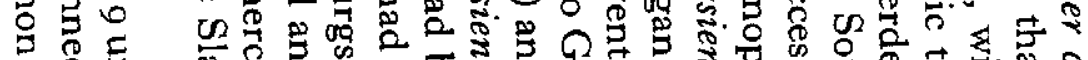

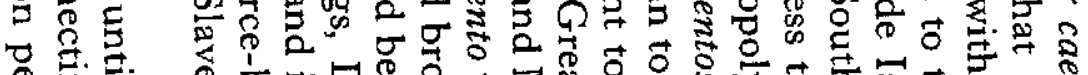

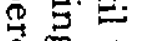
$0^{\infty} \infty$ 蚶学 要通

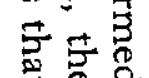

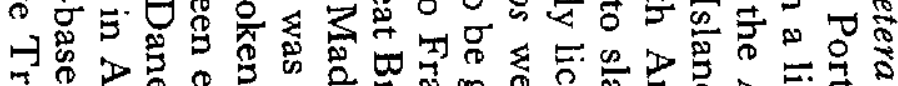

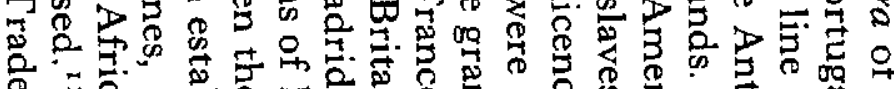
二

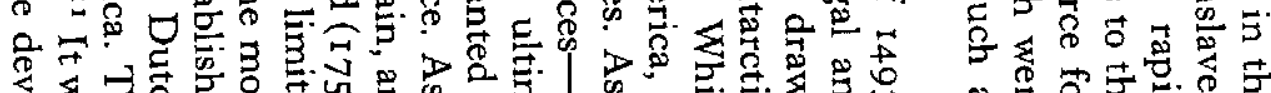

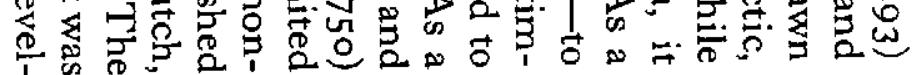

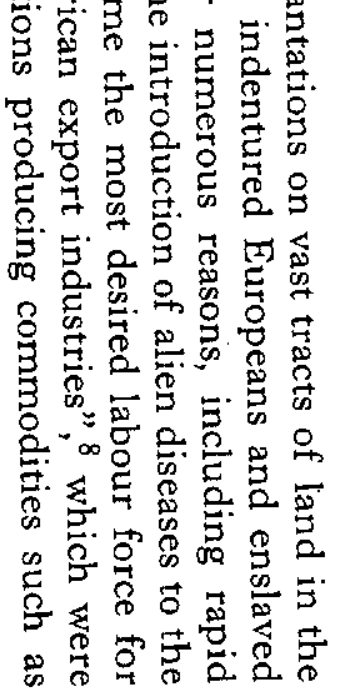




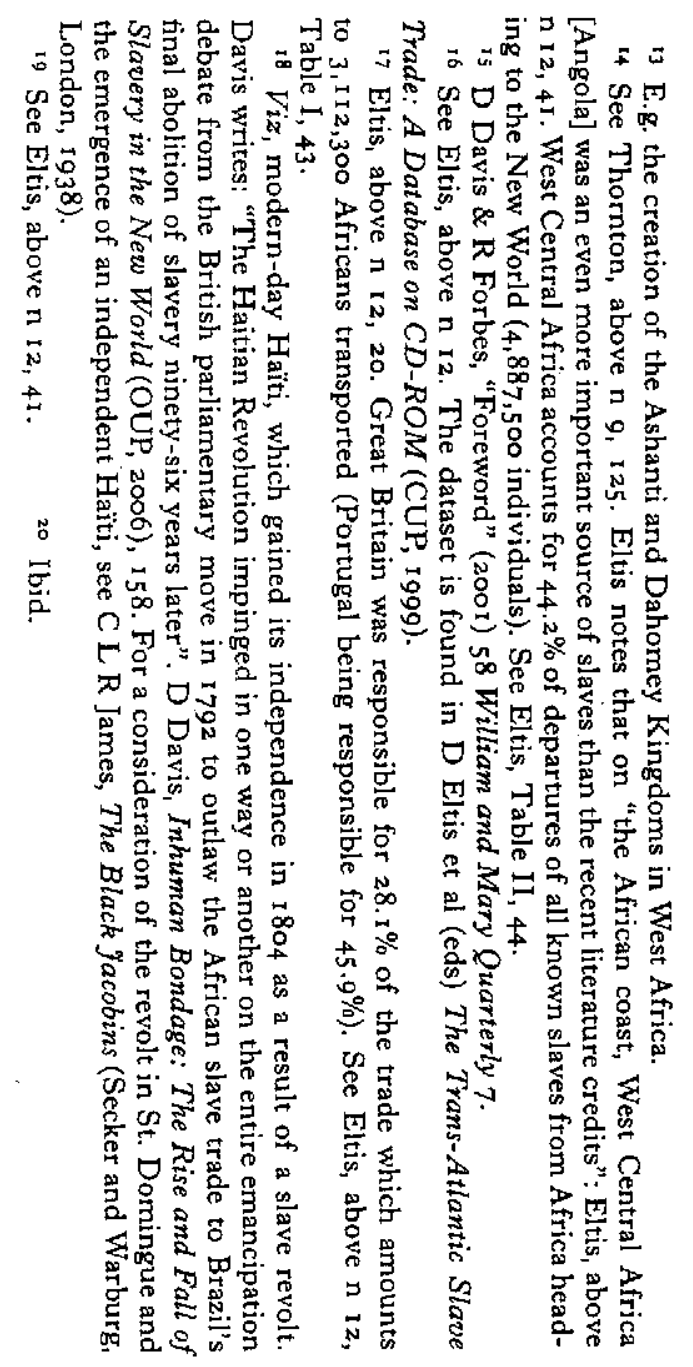

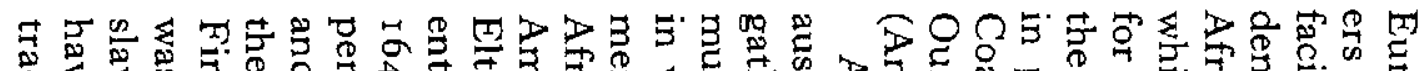
م.

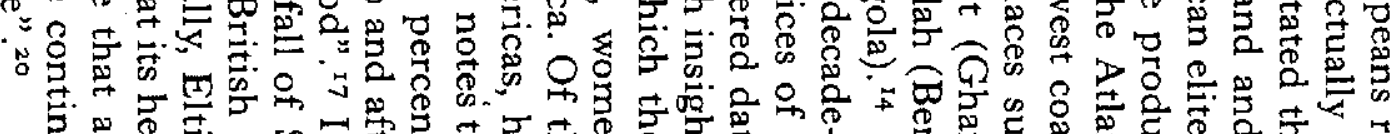

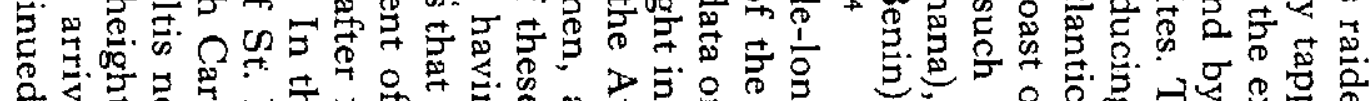

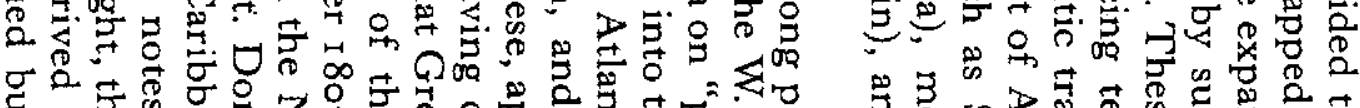

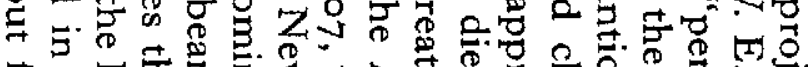

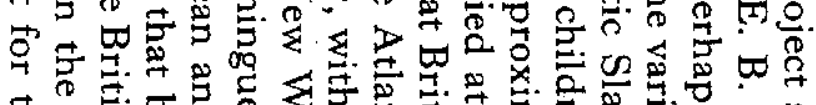

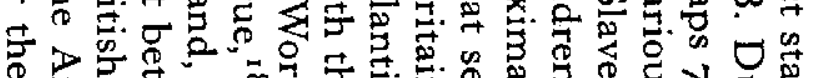
6

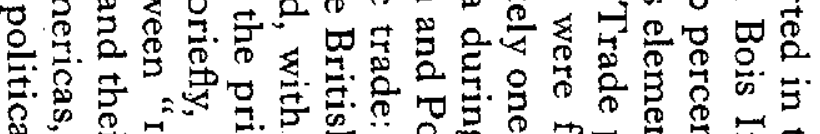

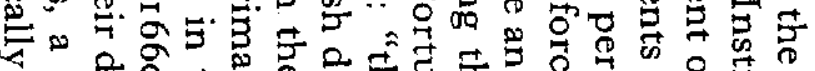

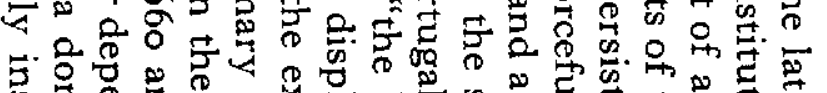

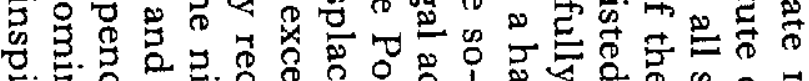

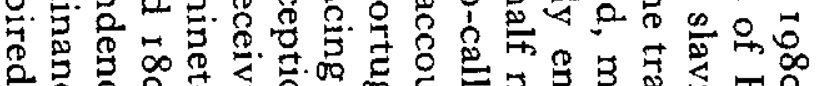

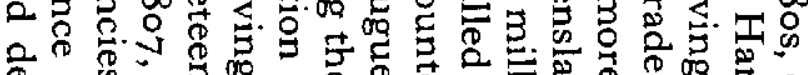

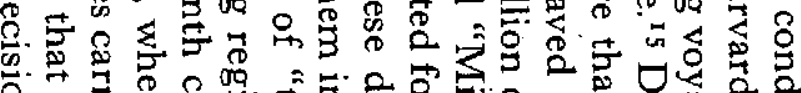

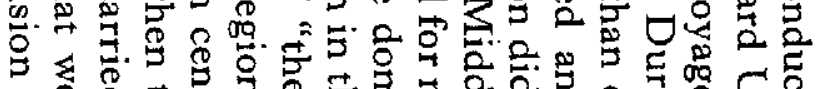

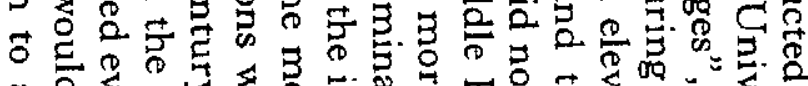

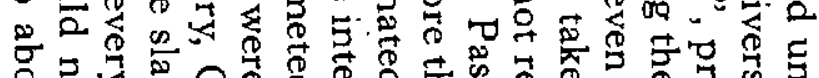

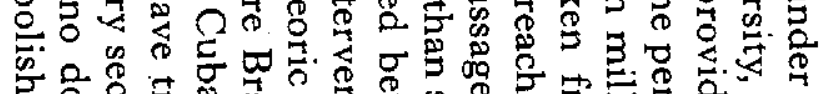

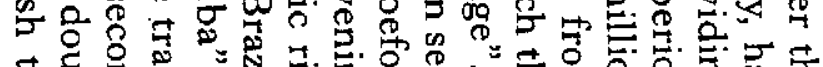

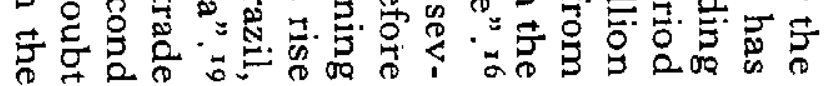

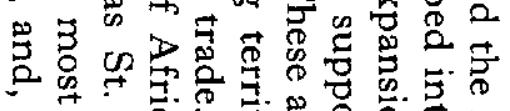

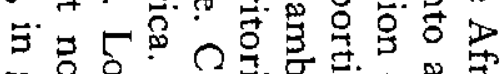

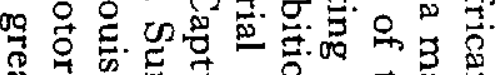

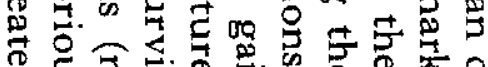

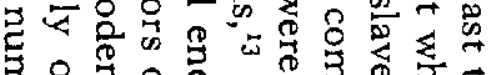

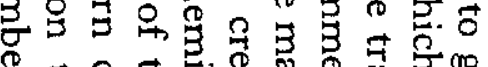

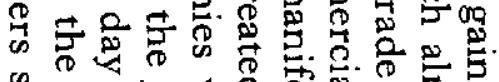

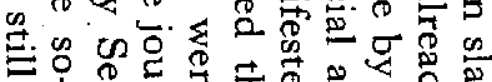

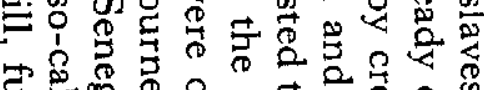

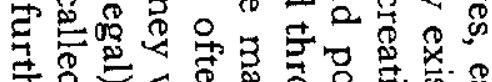
की की

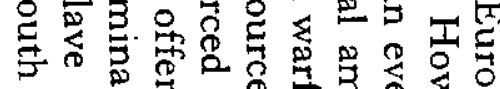

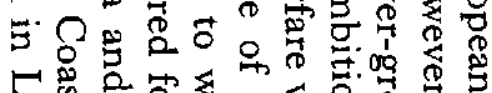

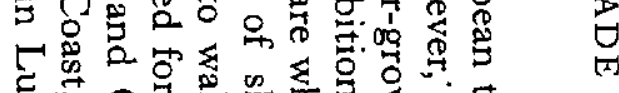

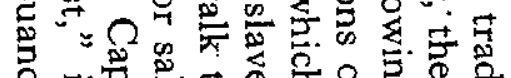

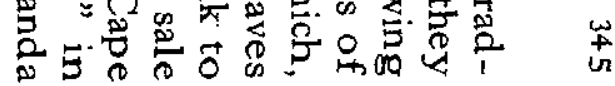

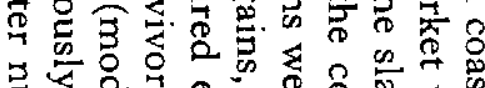

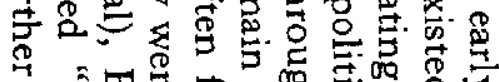




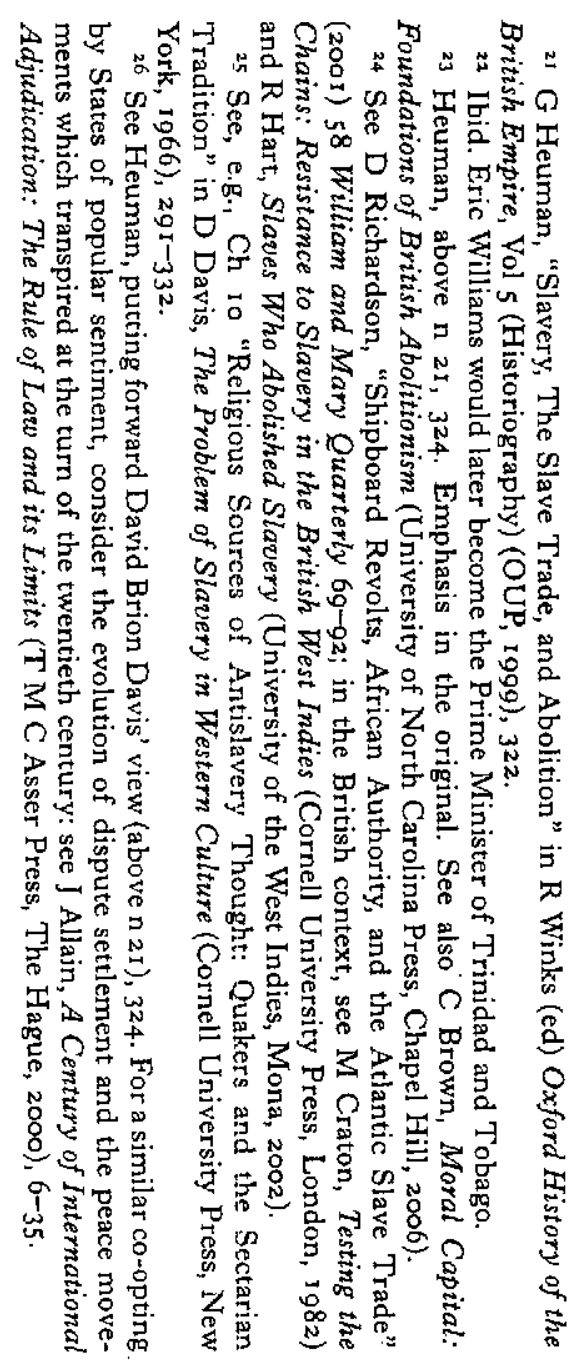

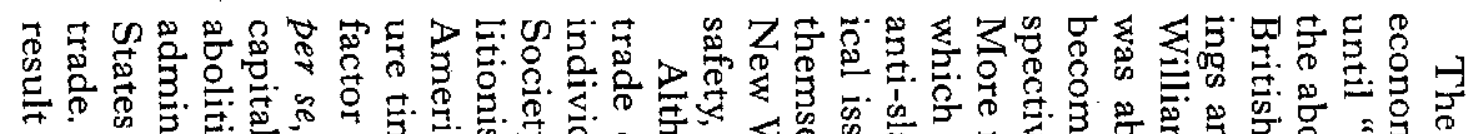

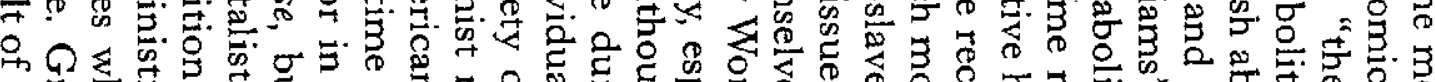

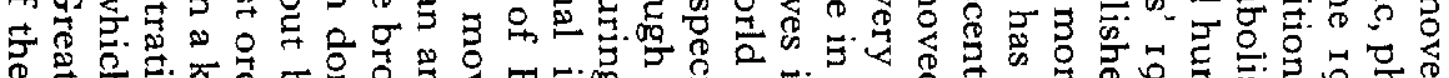

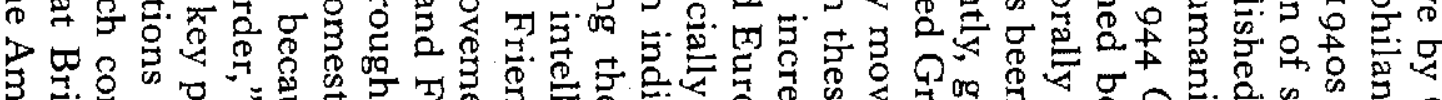

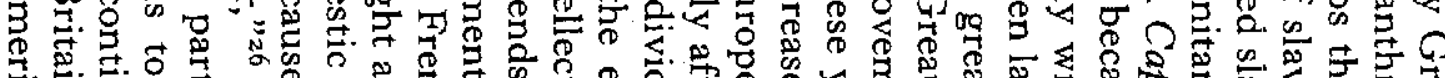

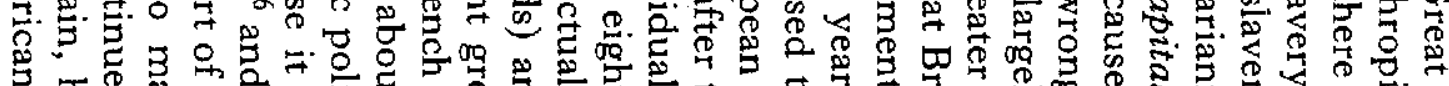

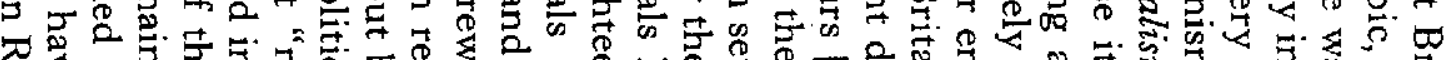

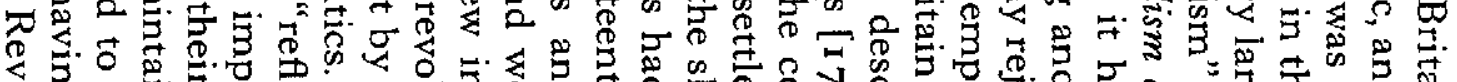

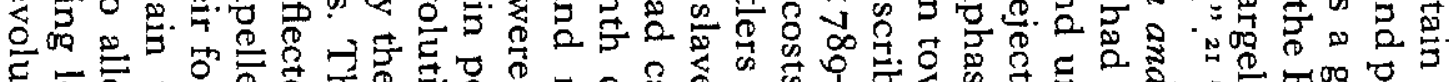

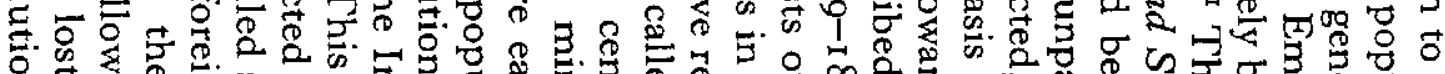

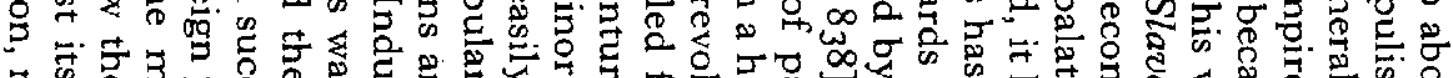

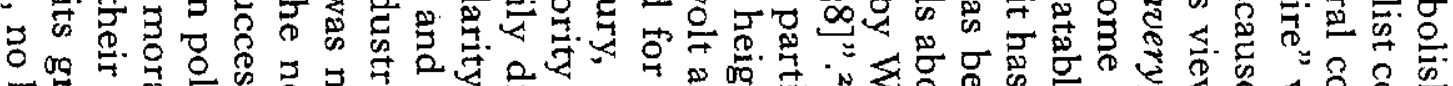

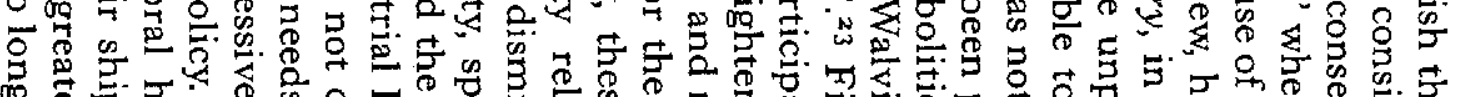

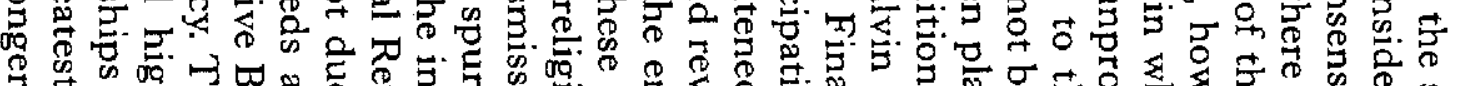

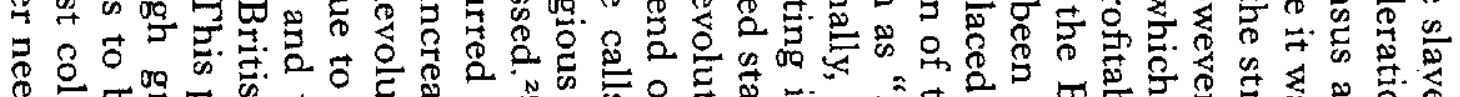

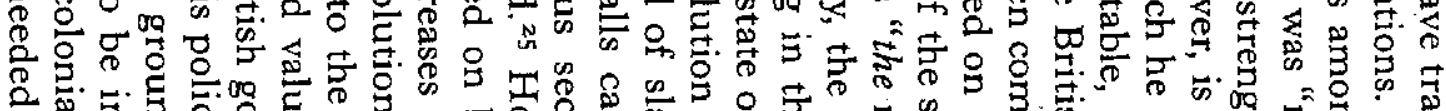

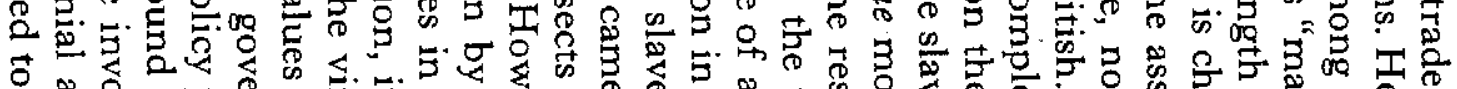
总要

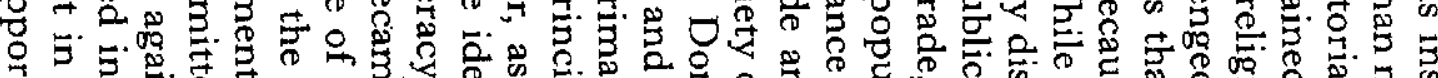

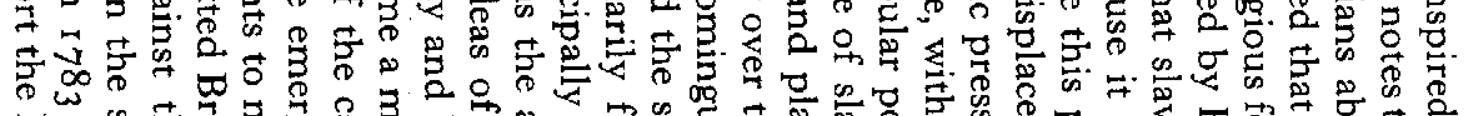

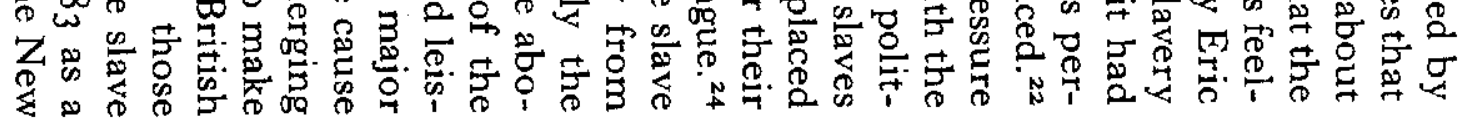




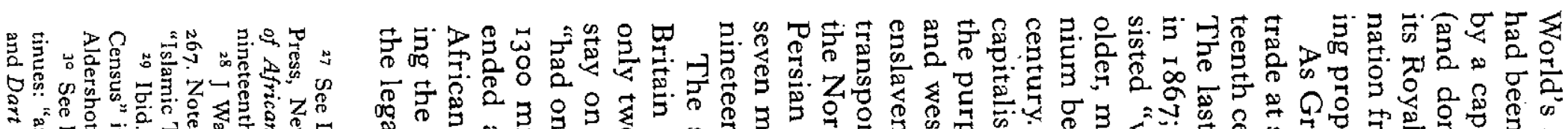

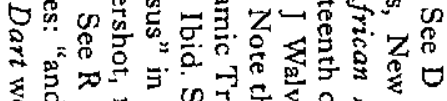

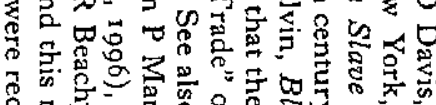

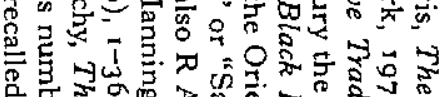

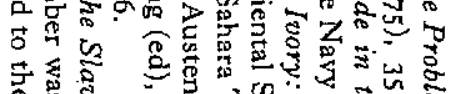

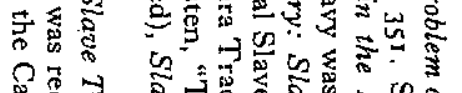

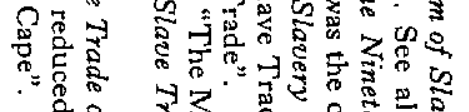

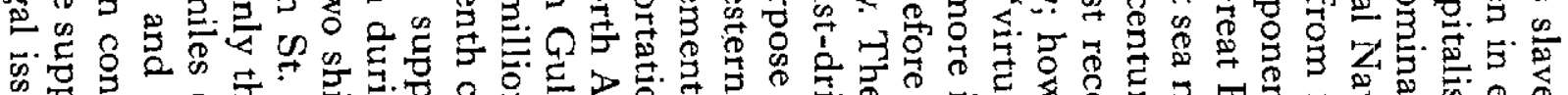

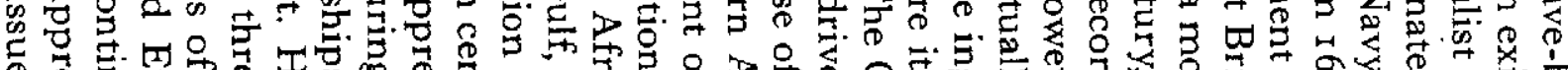
i

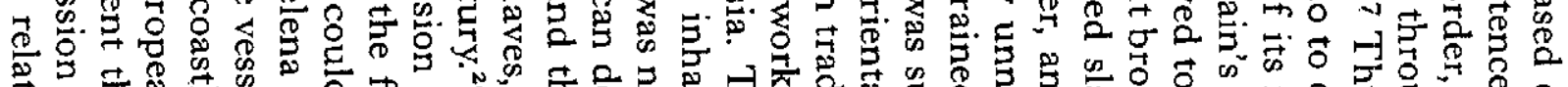

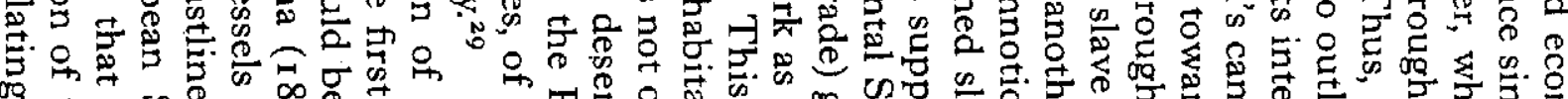

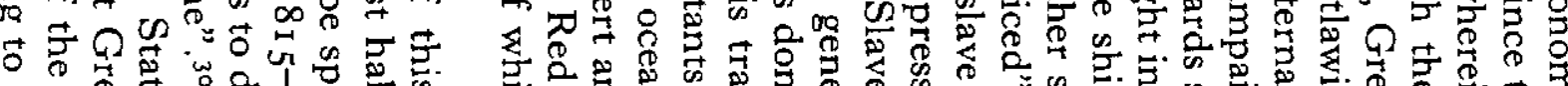

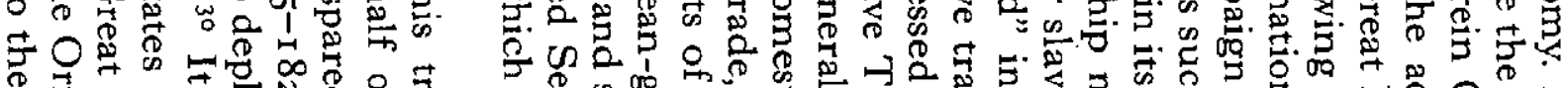

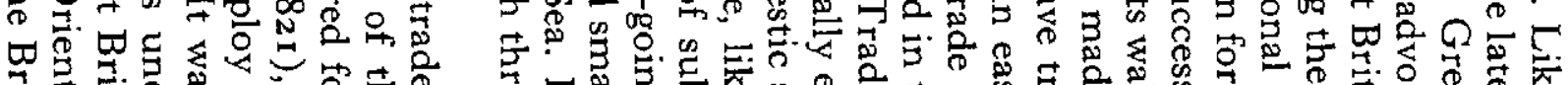

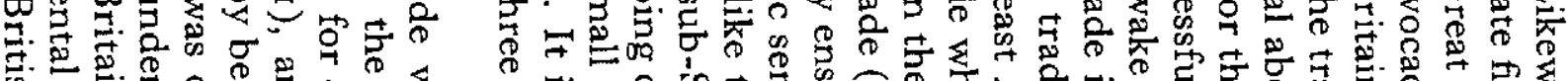

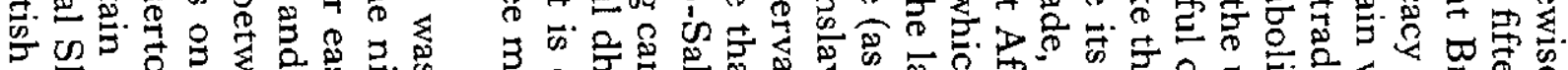

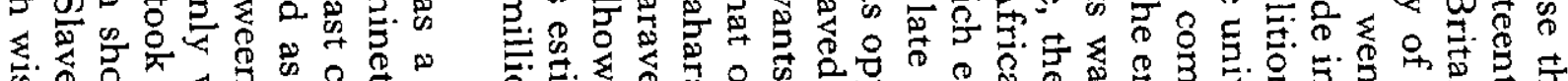

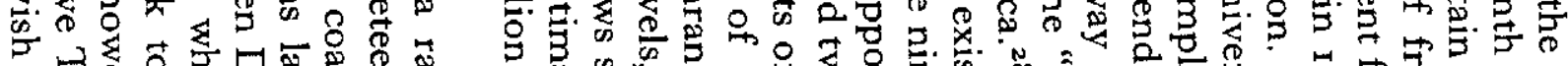

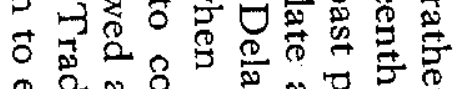

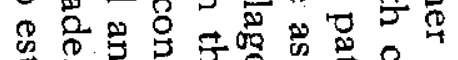

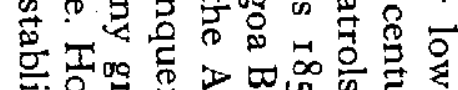
क.

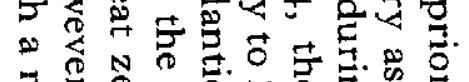
空.

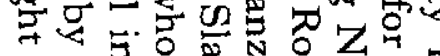

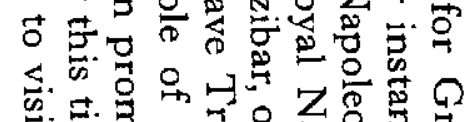

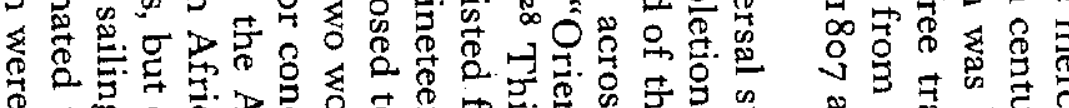

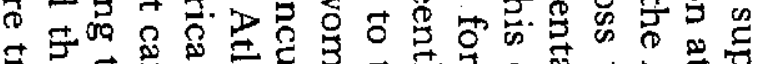

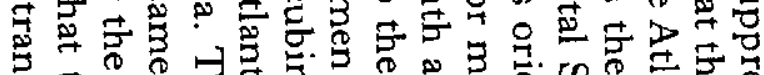

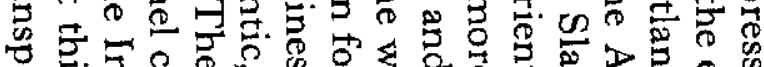

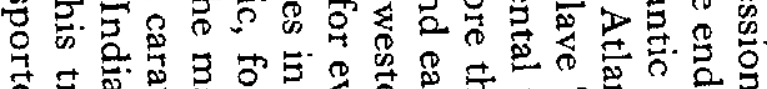

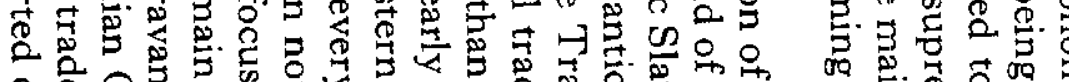
20 0 क

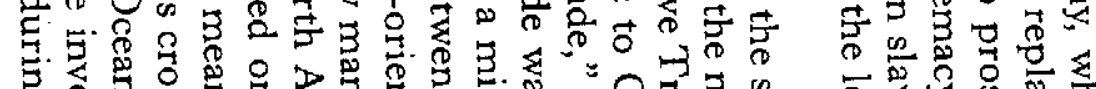

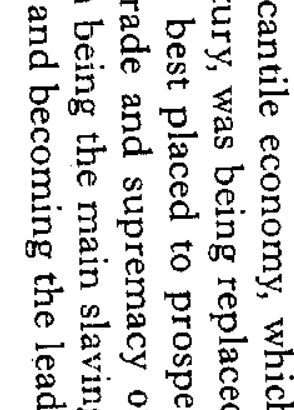

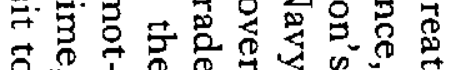

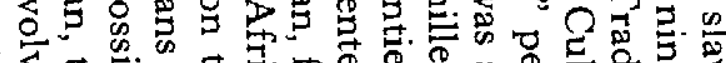

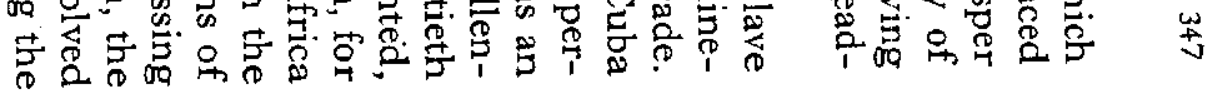




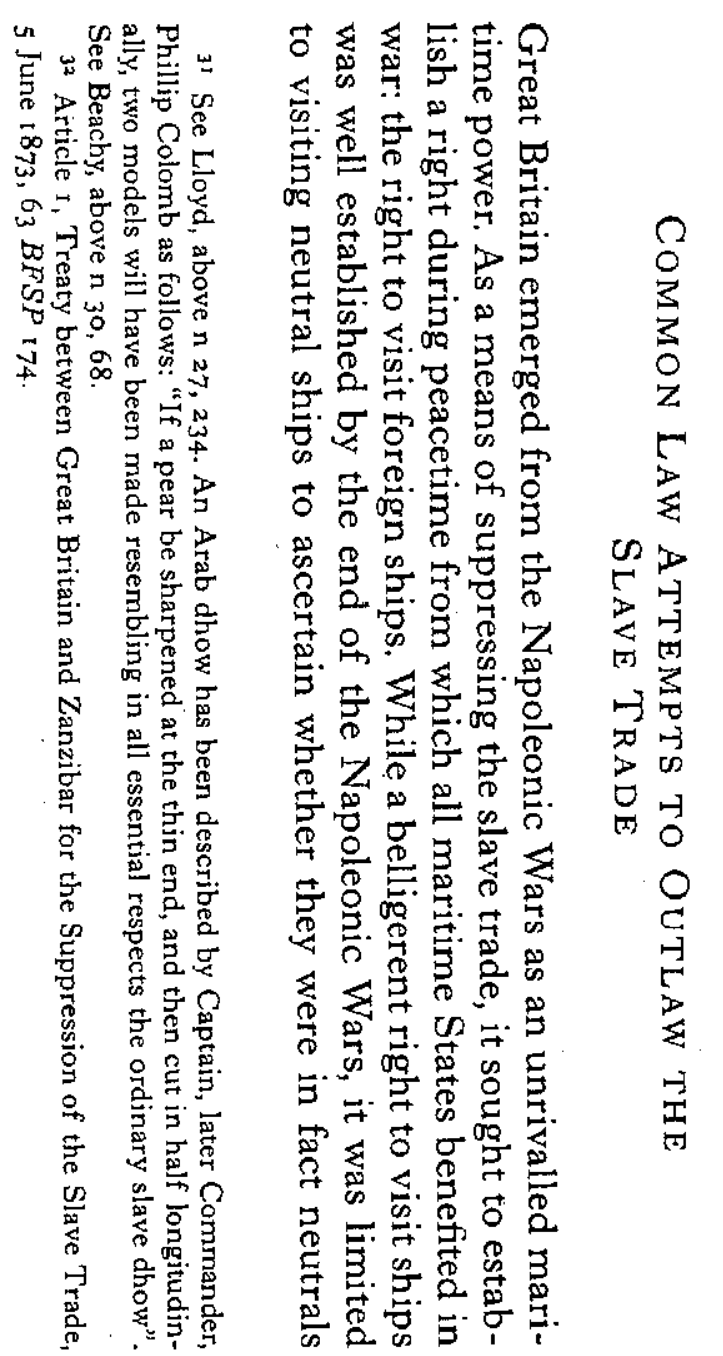

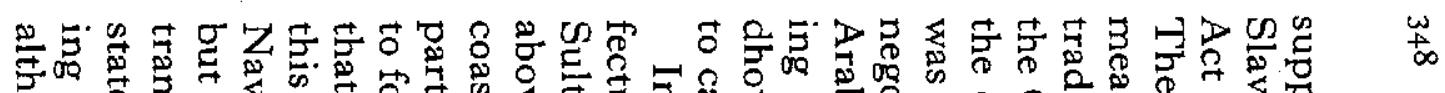

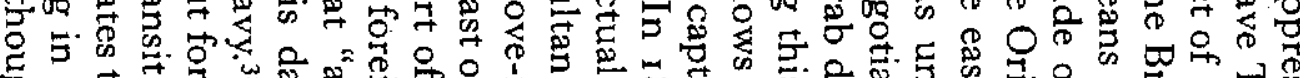

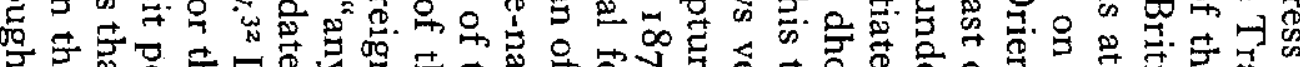

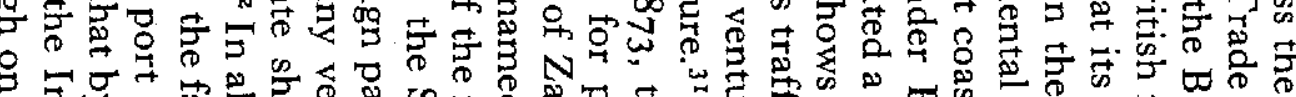

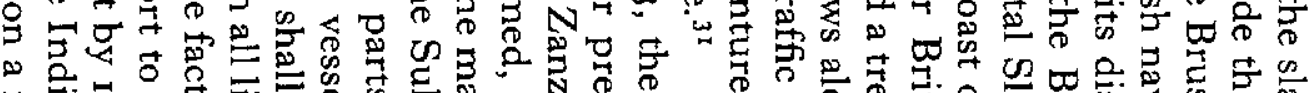

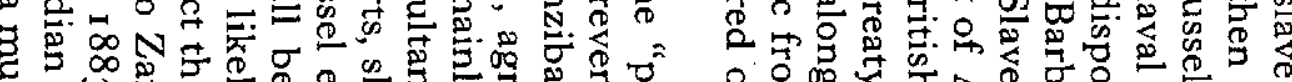

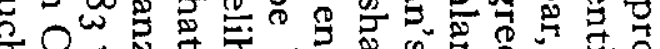
उ

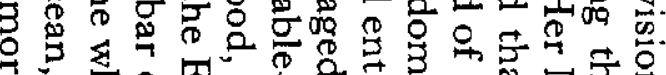

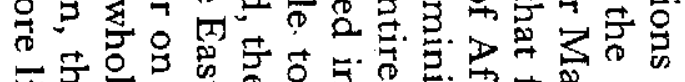

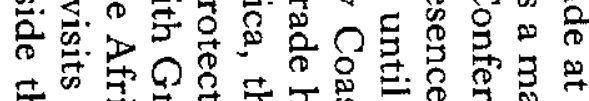

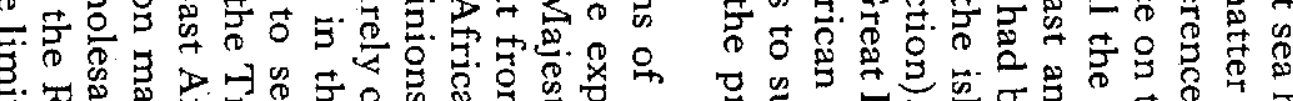

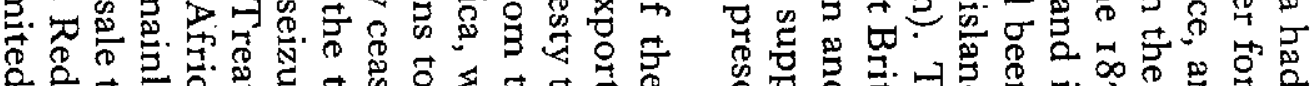

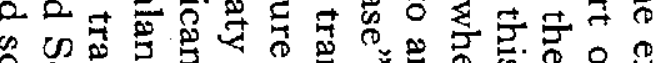

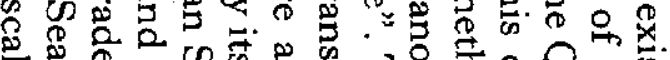

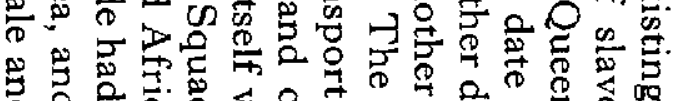

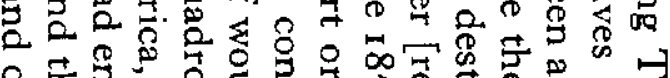

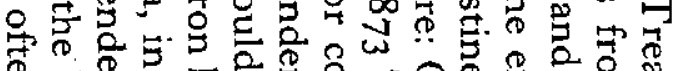

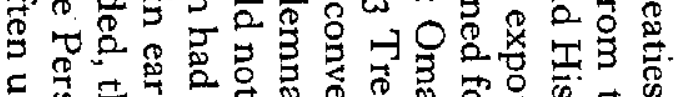

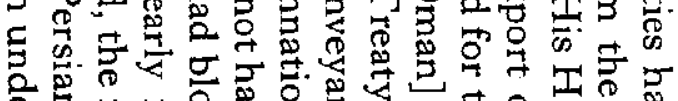

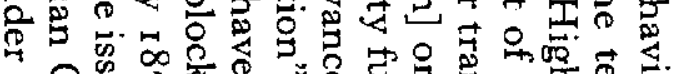

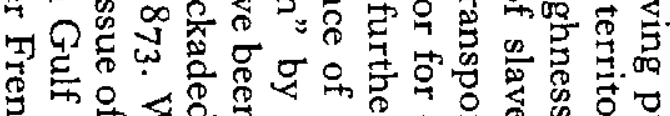
은

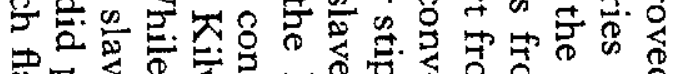

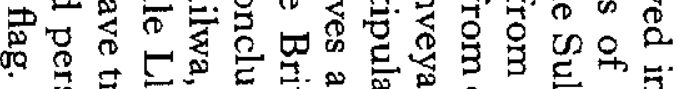

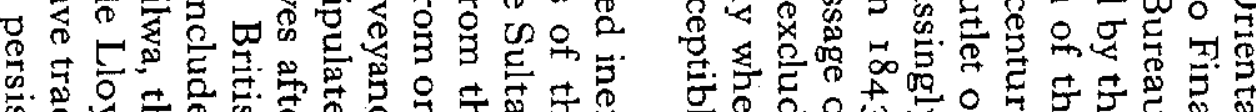

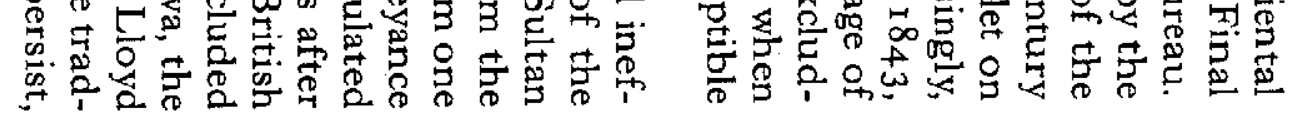

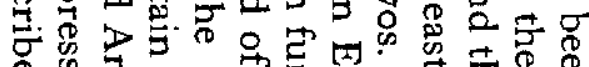

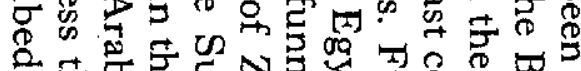

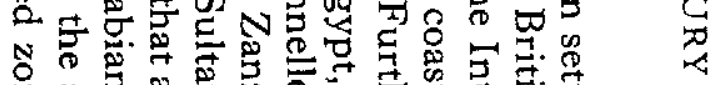

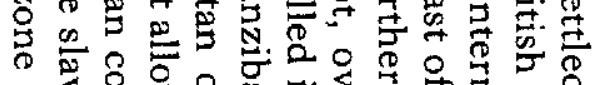

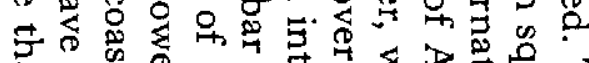

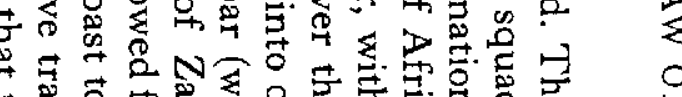

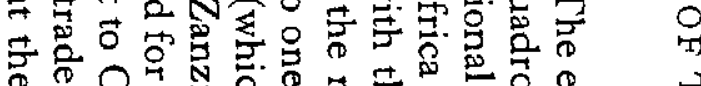

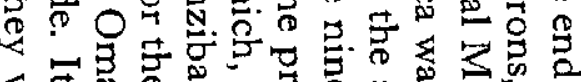
等

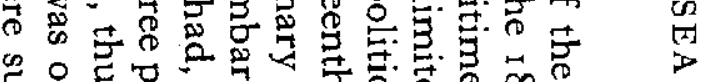

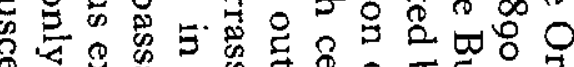

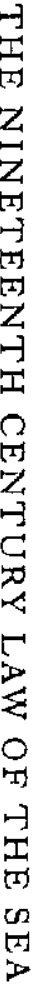



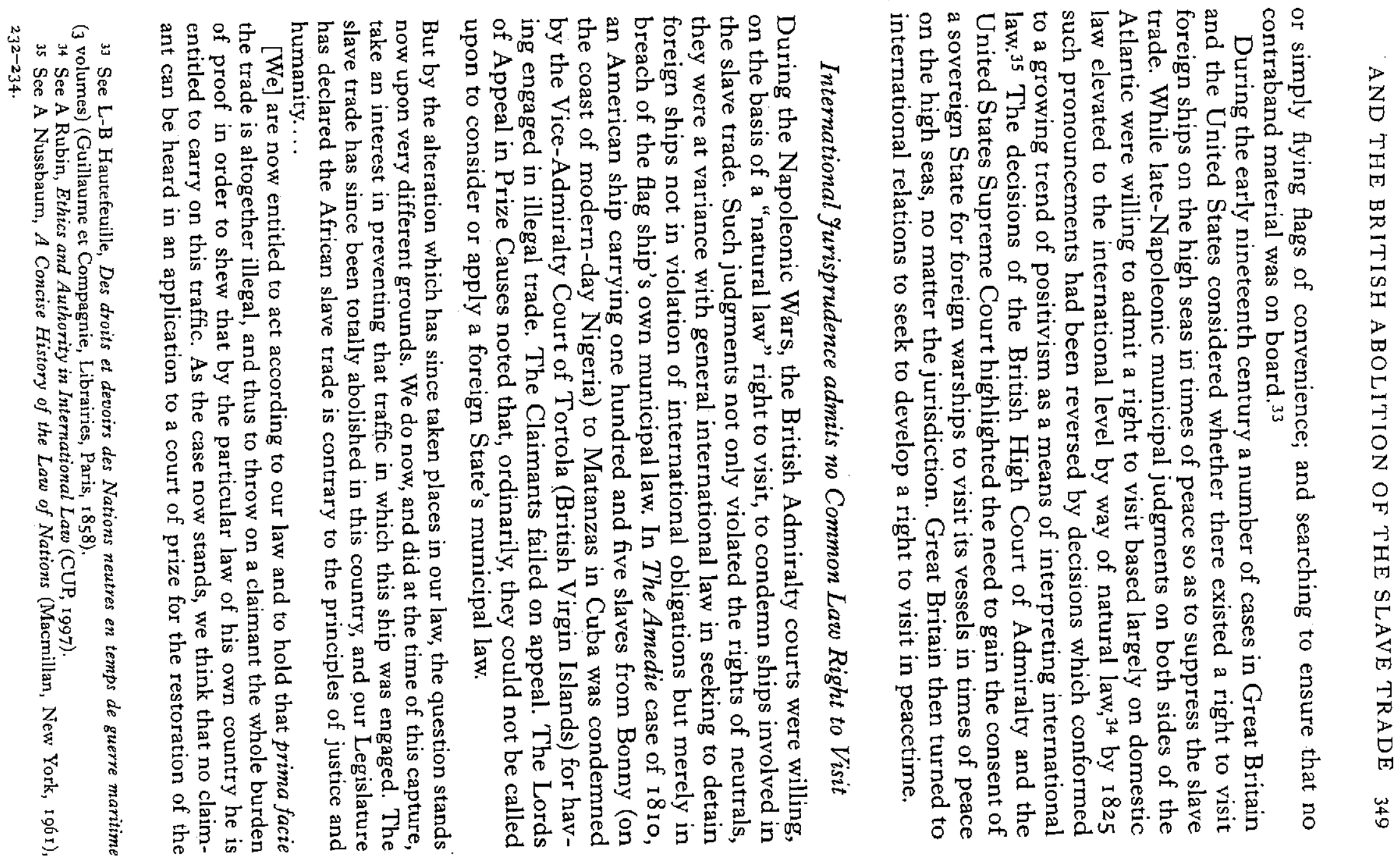


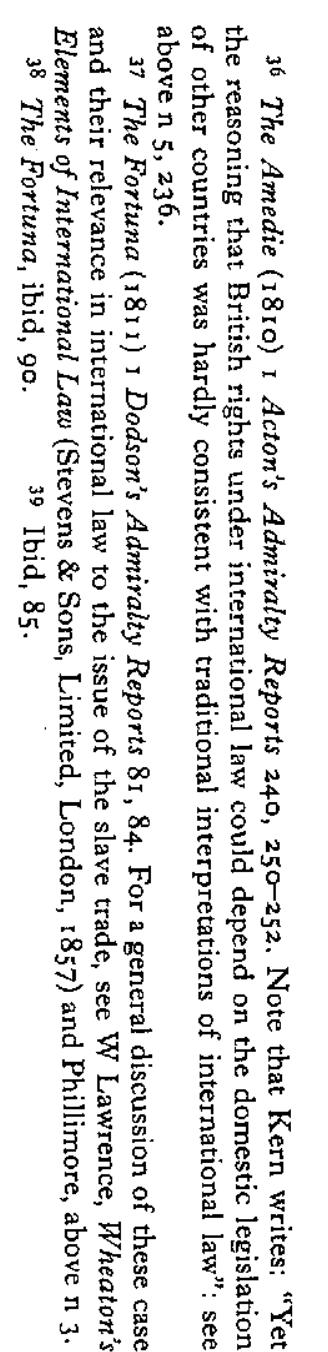

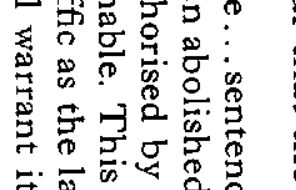
F.)

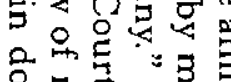

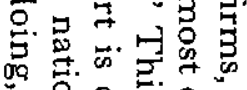

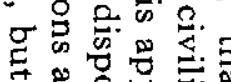

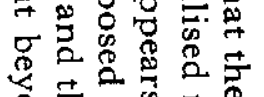

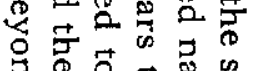

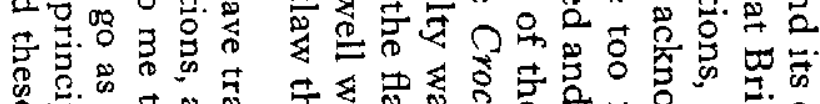

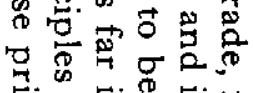
客. $\begin{gathered}0 \\ 0\end{gathered}$

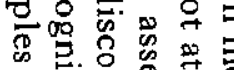

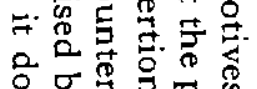

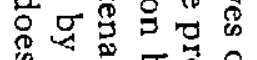

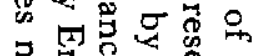

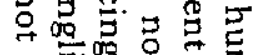

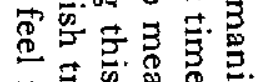

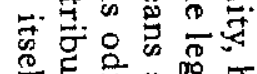

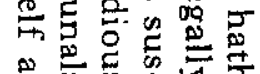

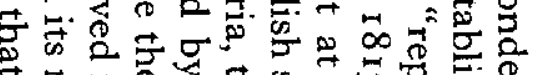

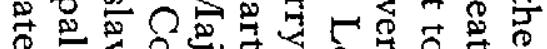

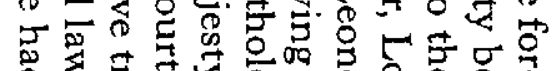

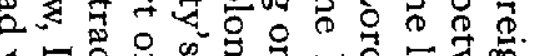

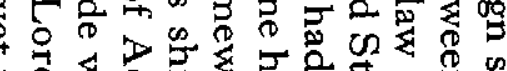

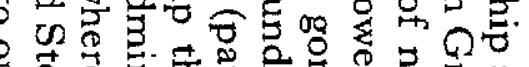

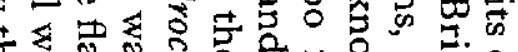
क on

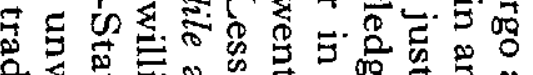

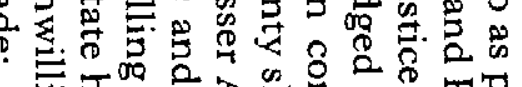

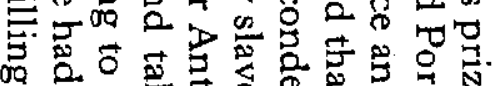

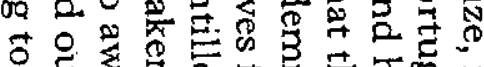

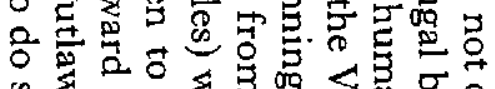

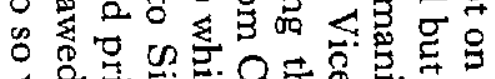

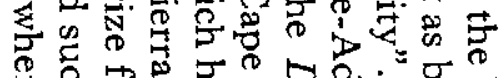

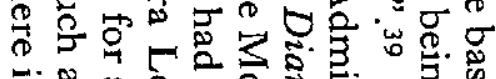

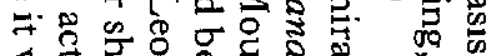

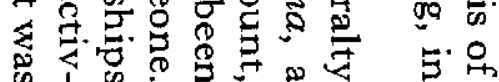

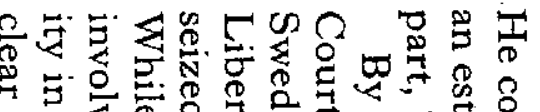

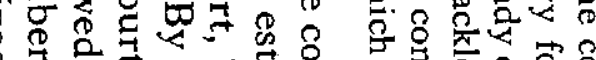

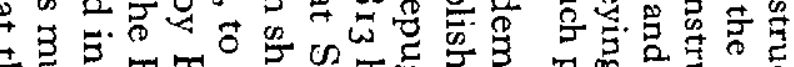

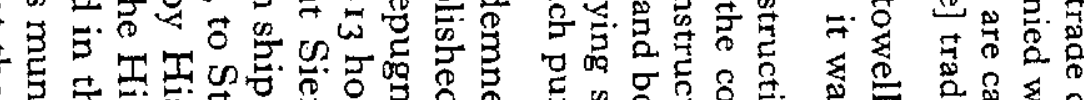

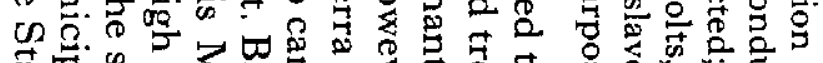

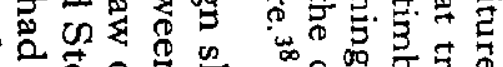

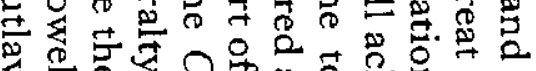

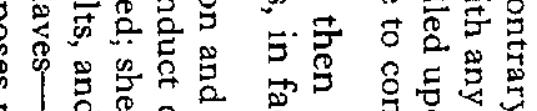

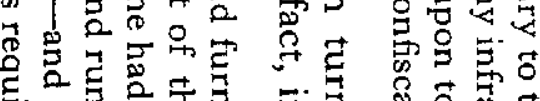

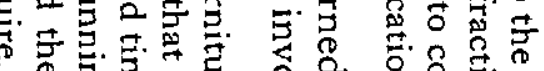

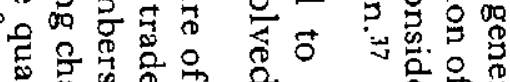

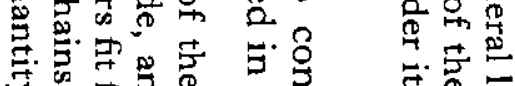

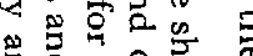
岂范实虽点

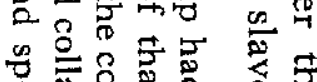
. 虽总总宫

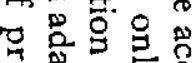

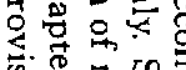

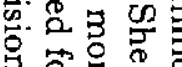
实家

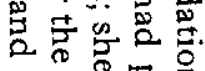

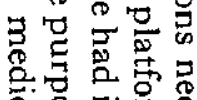

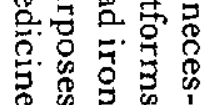
동. 융 究总

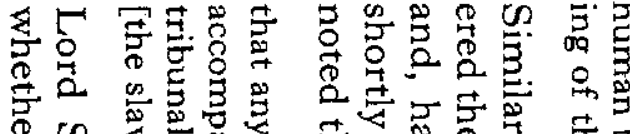

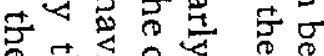

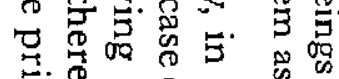

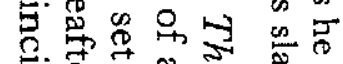
원 90

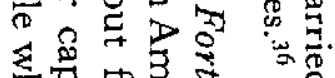

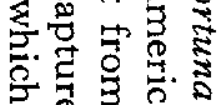

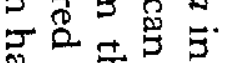

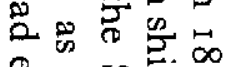

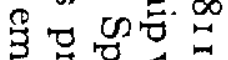

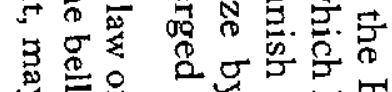

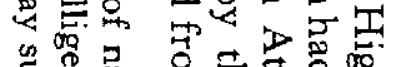

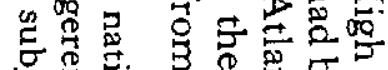
类 क्ष 站壱

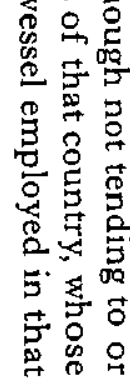

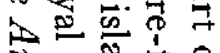

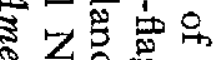

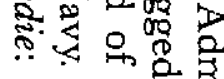
厂穴要. 苍苍豈 ए ॠ苋总

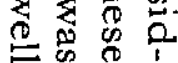




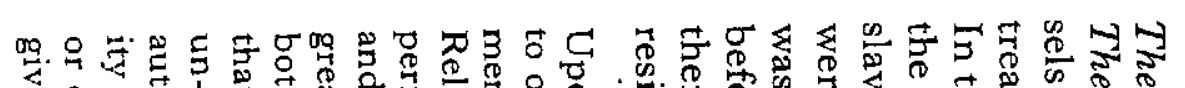

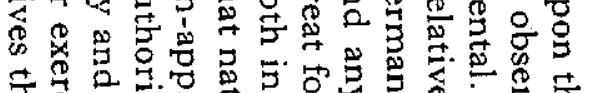
क

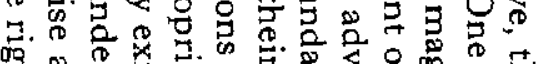

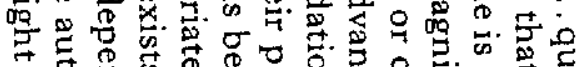

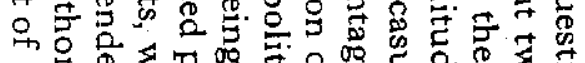

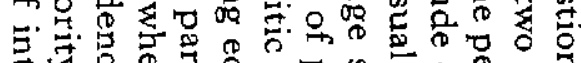

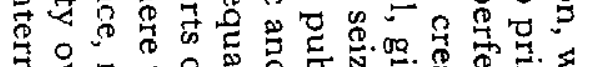

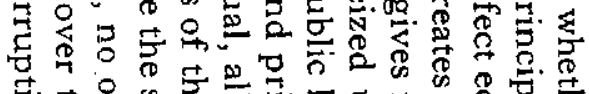

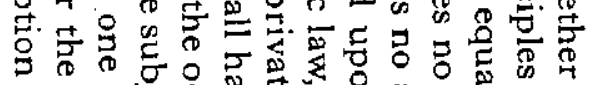

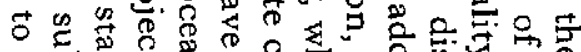

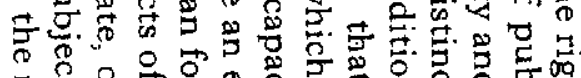

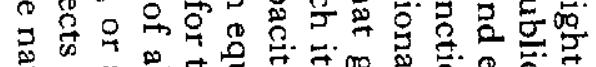

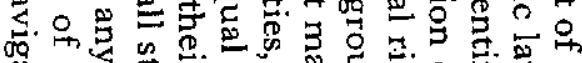

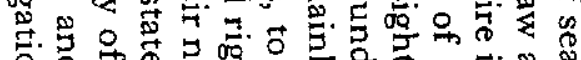

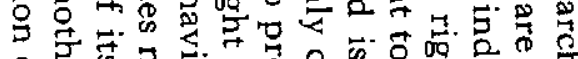

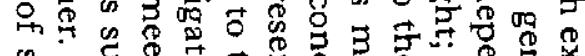

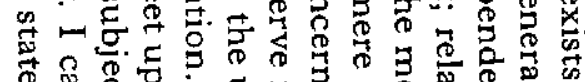

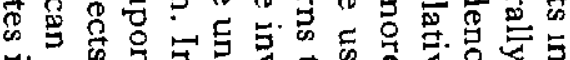

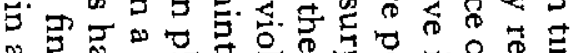

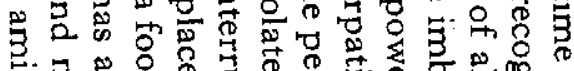

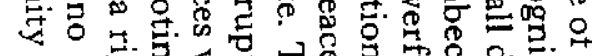

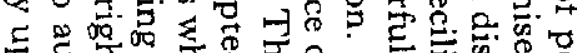

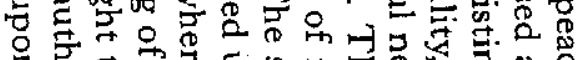

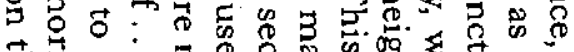

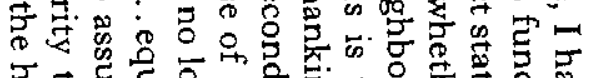

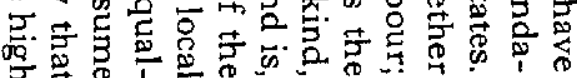

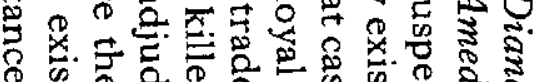

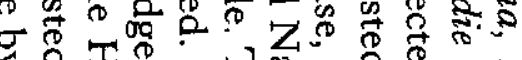

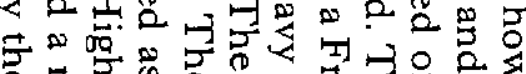
西

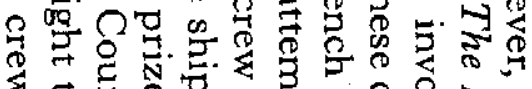

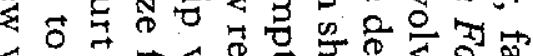

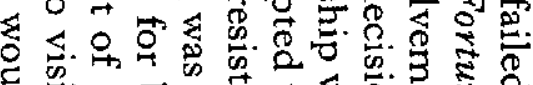

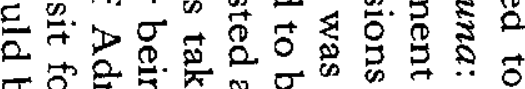
б.

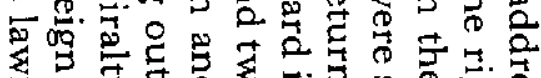

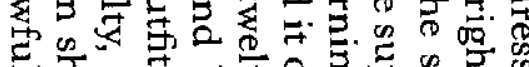

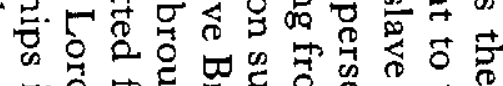

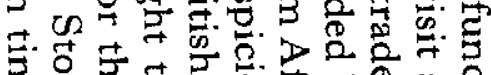

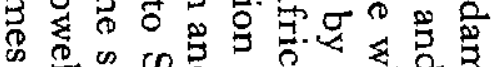
क

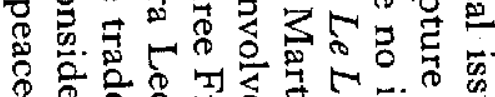

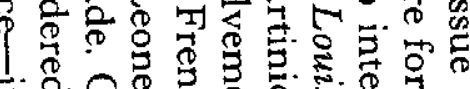

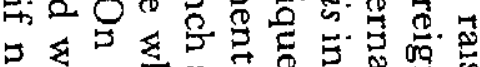
O

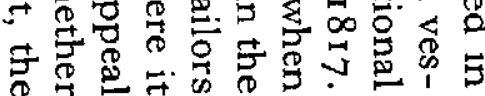

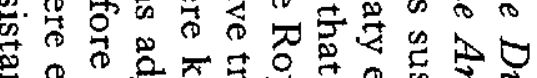

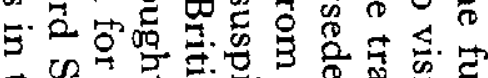

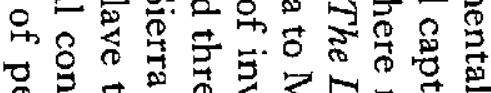

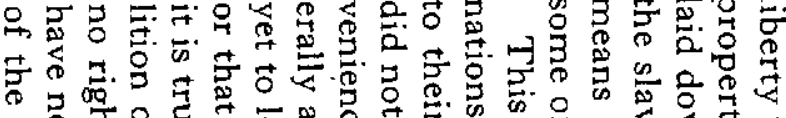

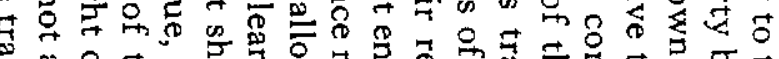

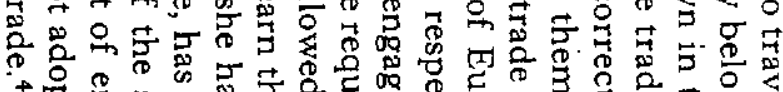

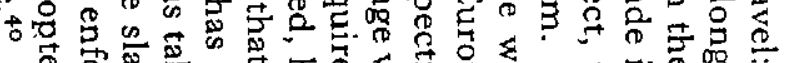

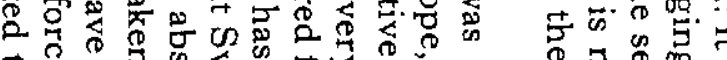

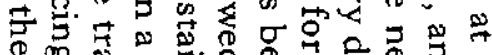

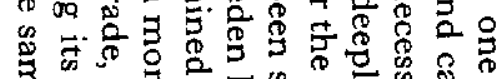

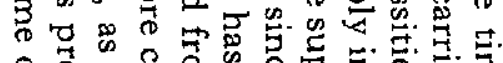

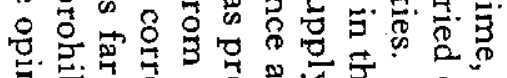
5.

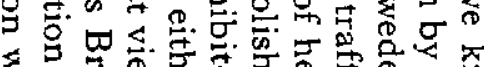

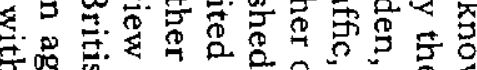

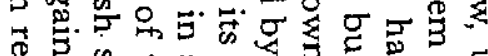

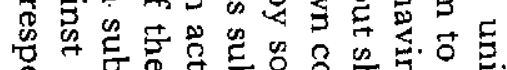

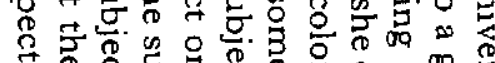

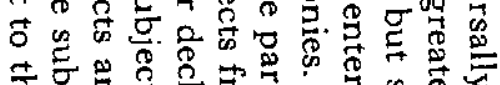

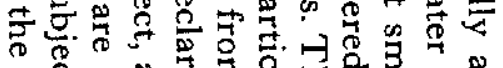

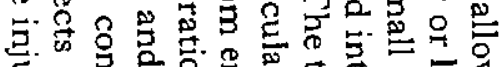

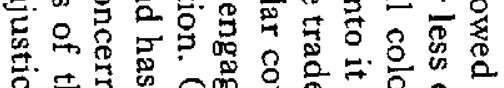

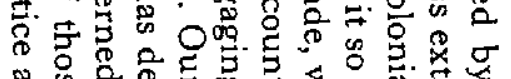

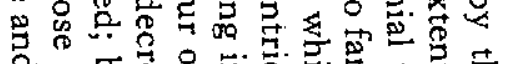

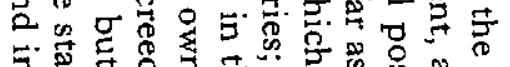

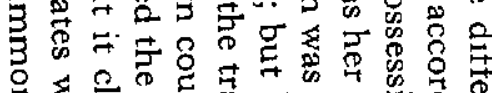

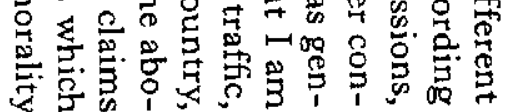

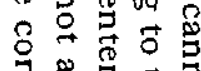

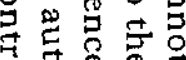

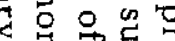

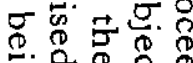
प्रति

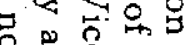
这安

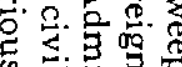

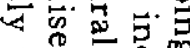

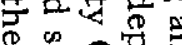

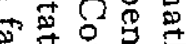

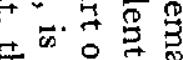

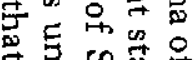

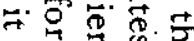
$4{ }^{\infty}$

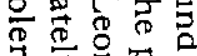

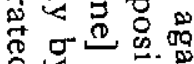
过宫宫 


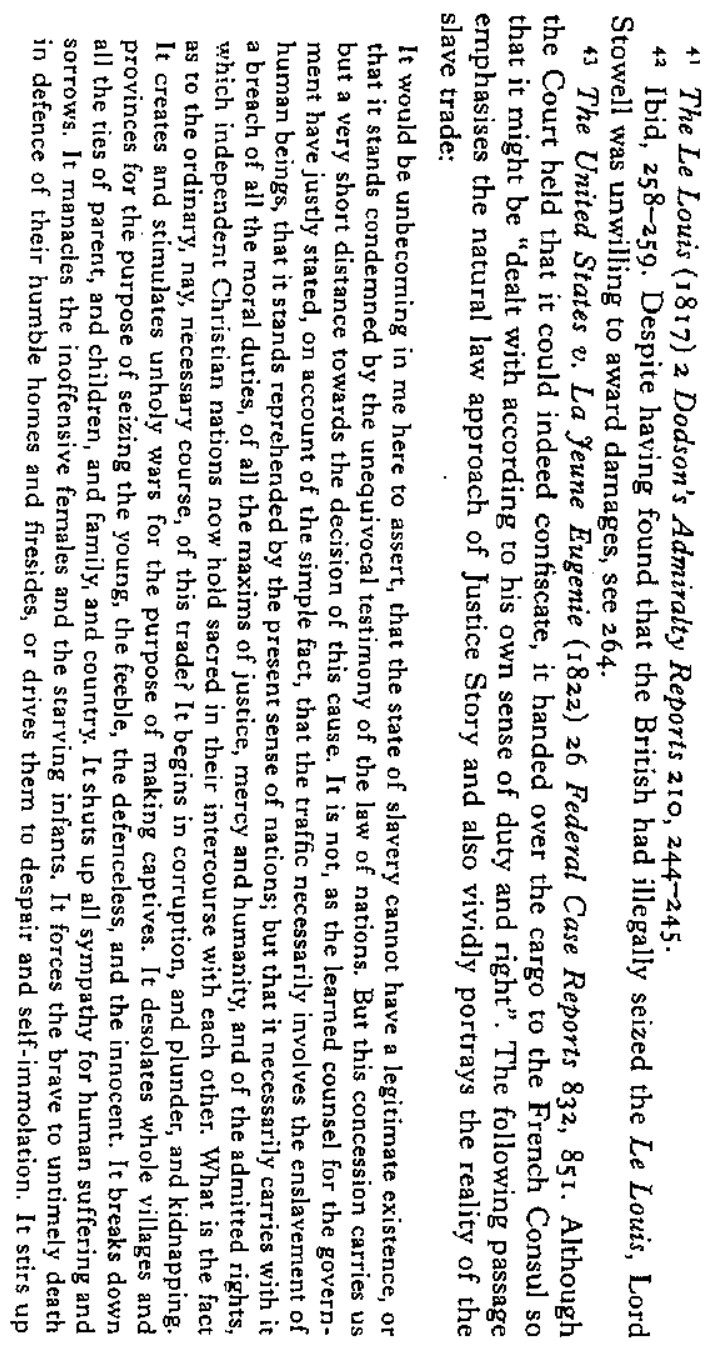

ㄱ.

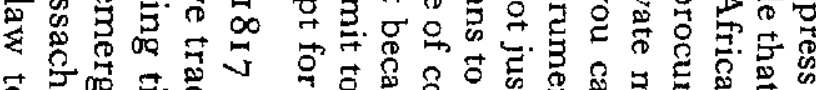

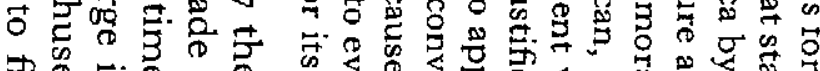

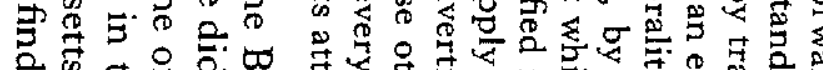

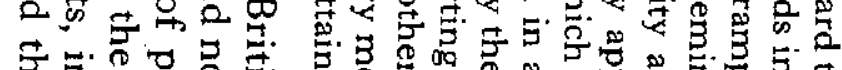

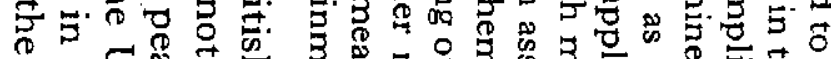

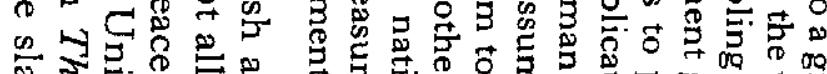

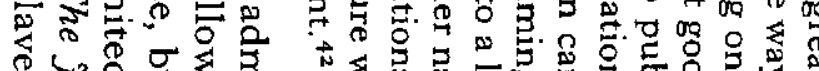
6 ᄂ.

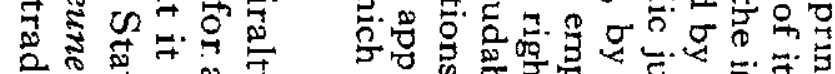

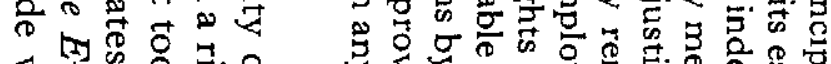

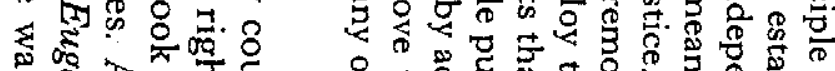

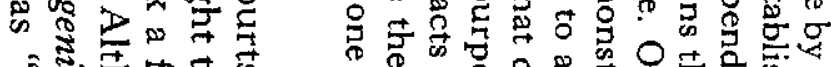

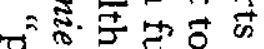

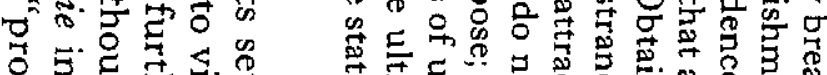

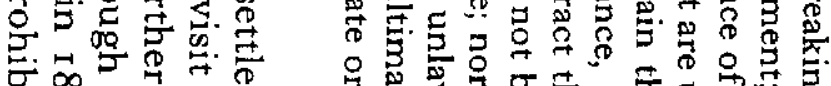

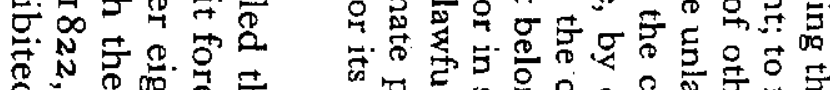

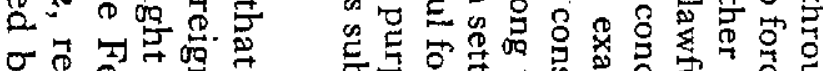

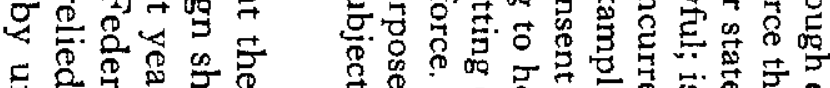

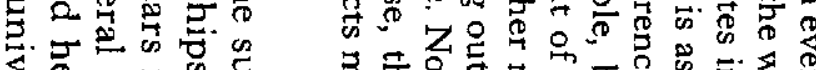

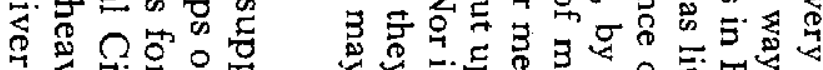

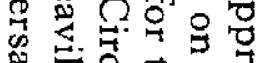
4

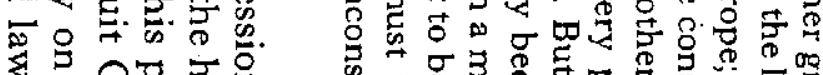

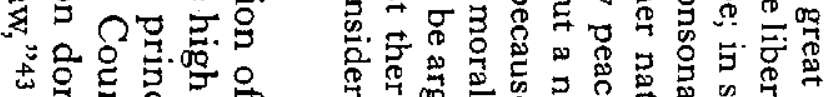

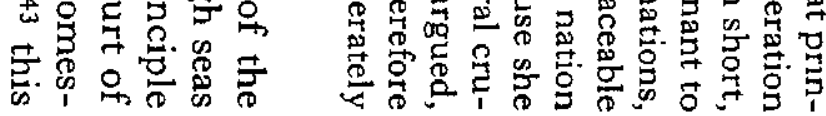

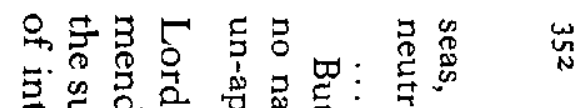

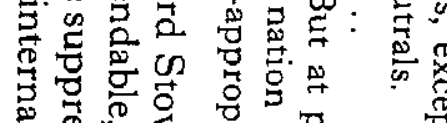

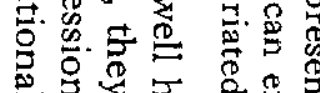

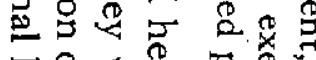

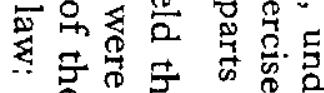

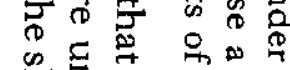

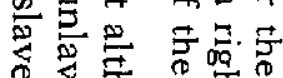

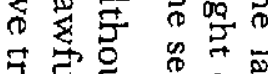

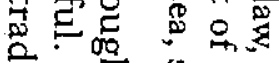

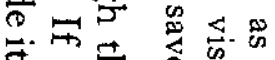
政宫

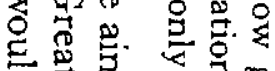

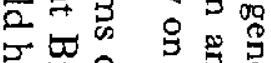

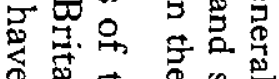

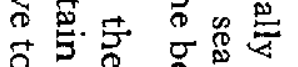

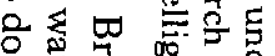

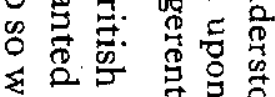
전 5. 8 要 究昰 ᄋ 둥 高鲜

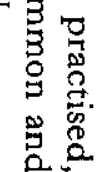

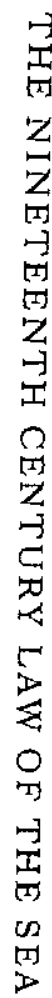




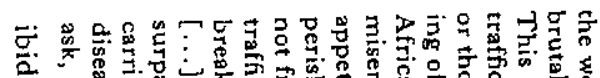

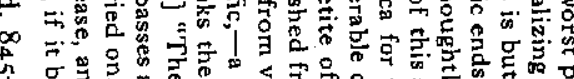

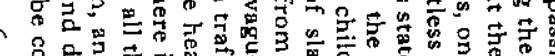

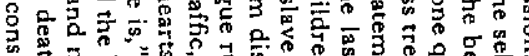

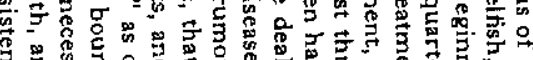

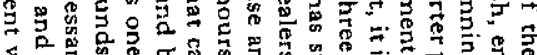

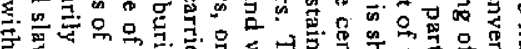

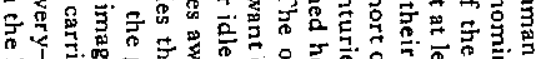

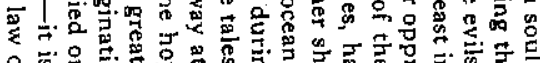
品

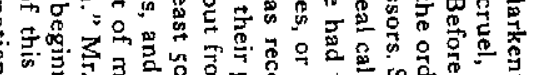

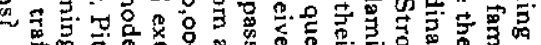

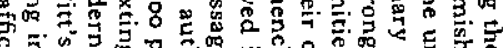
5.

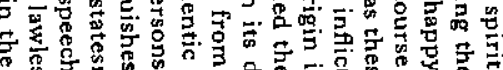
等

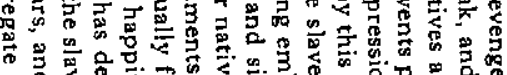

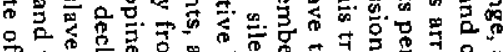

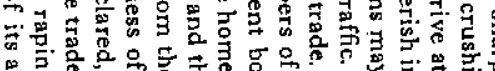

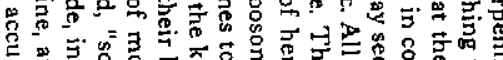

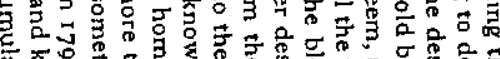

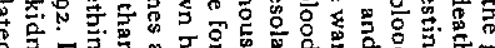

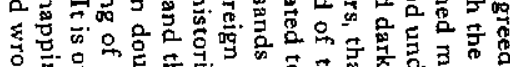

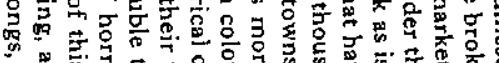

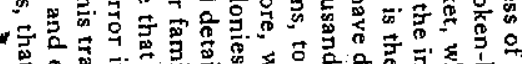

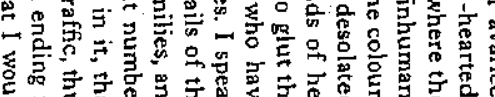

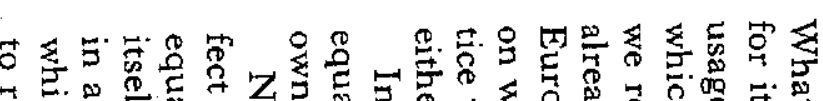

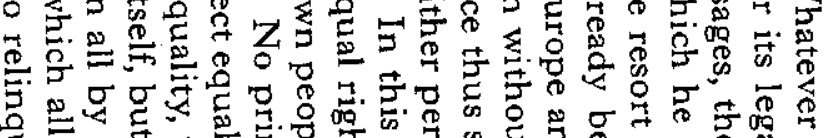

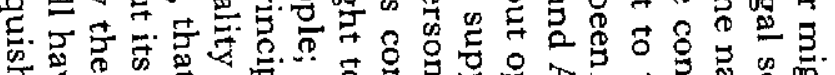

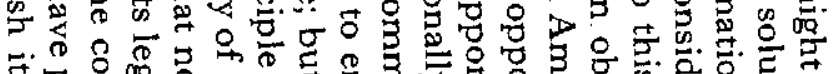

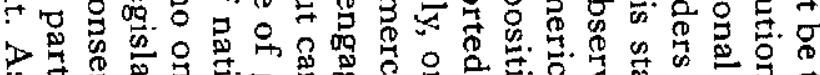

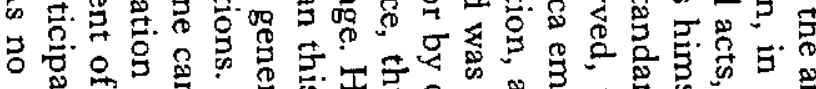

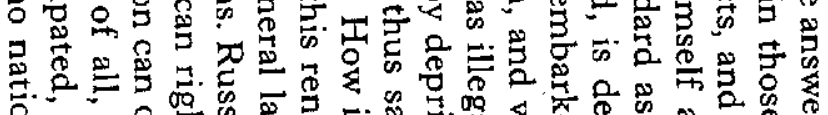

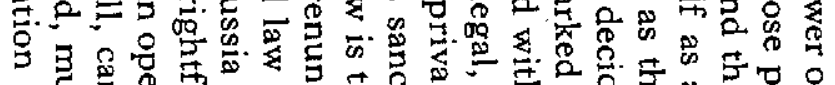

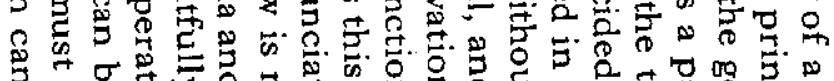

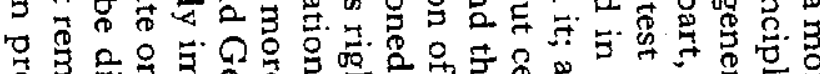

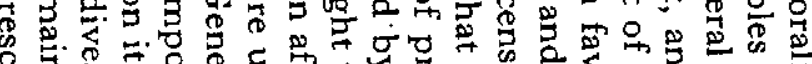

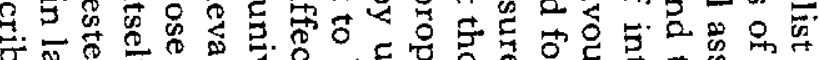

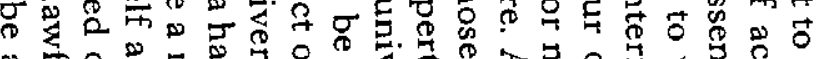
*

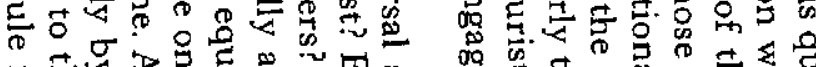

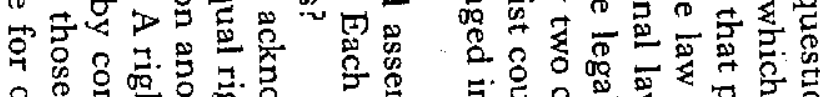

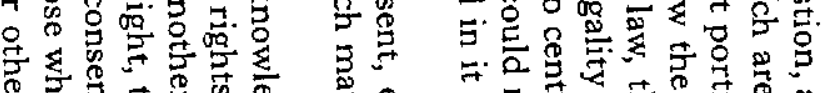

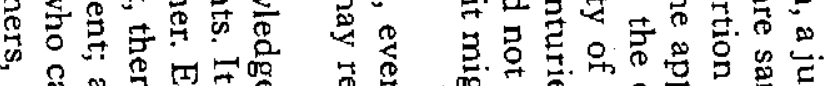

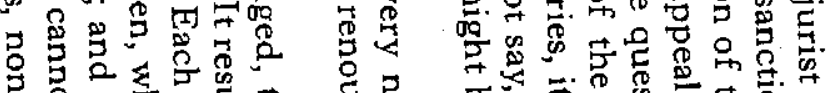

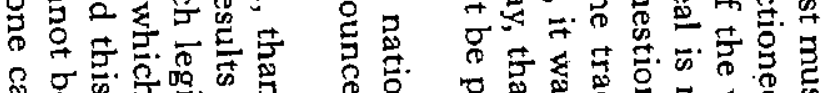

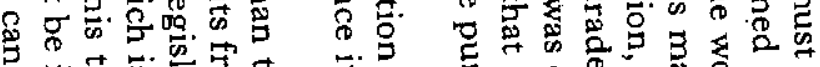

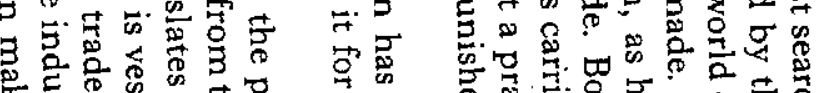

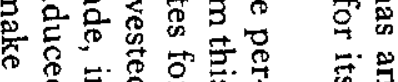

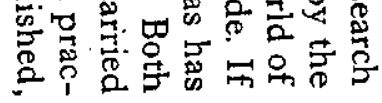

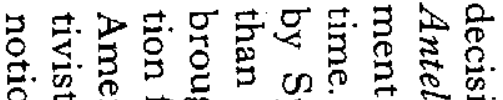

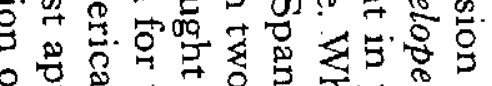

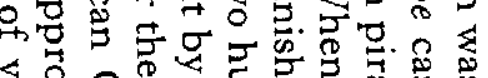

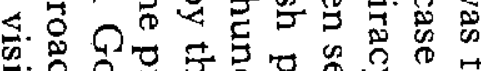

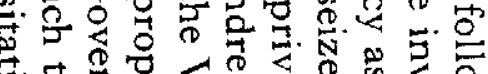

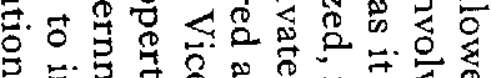

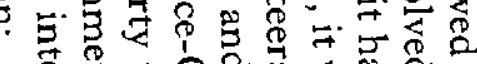

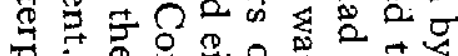

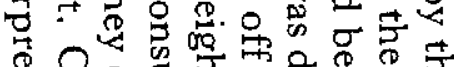

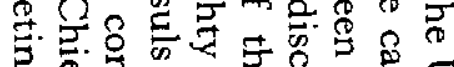

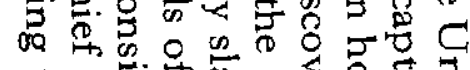

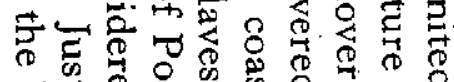

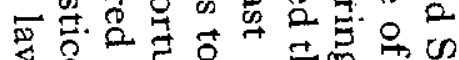

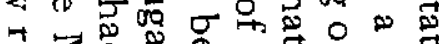

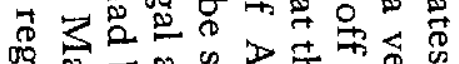

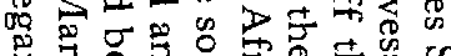

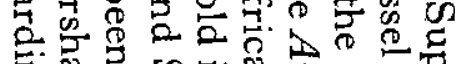

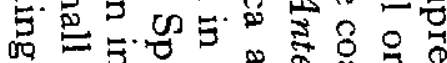

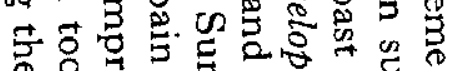

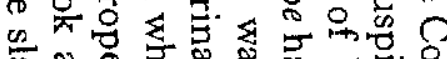

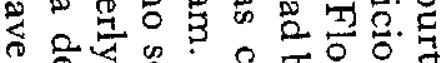

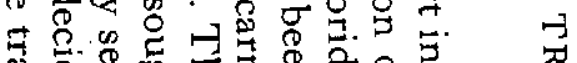

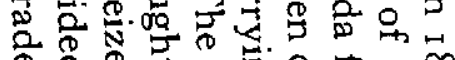

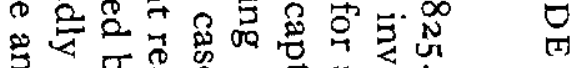

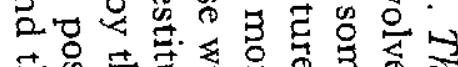
D 


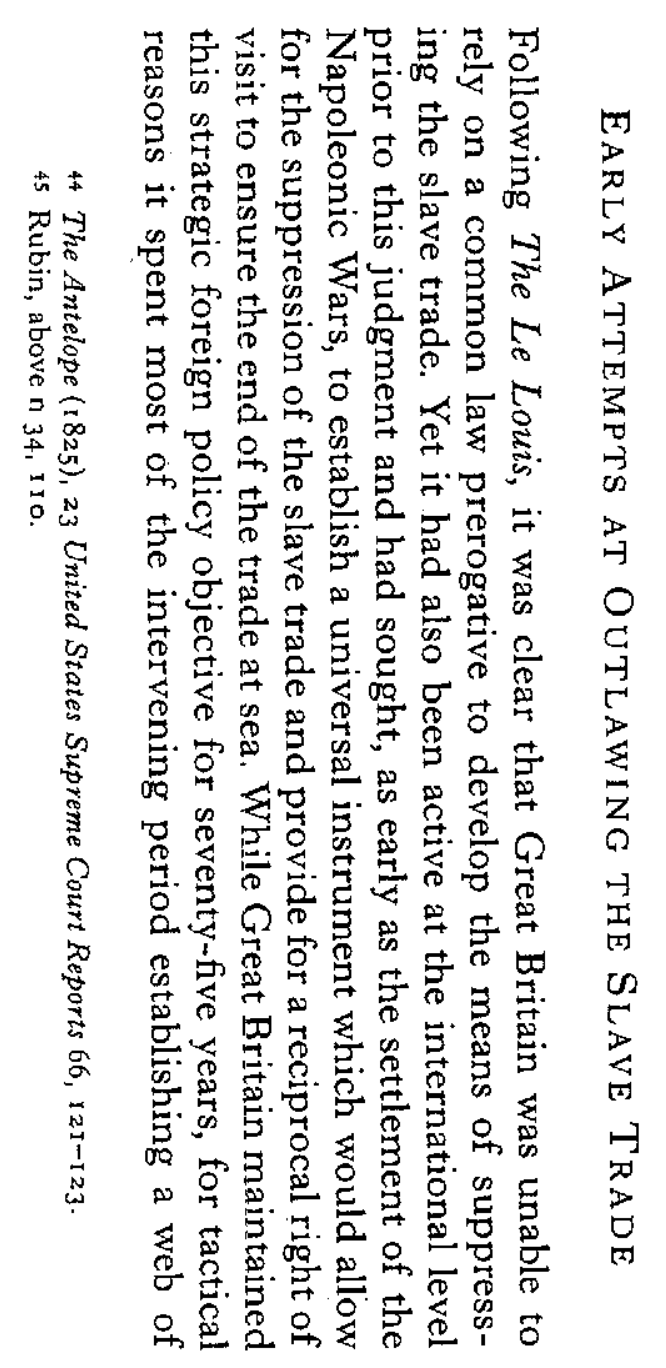

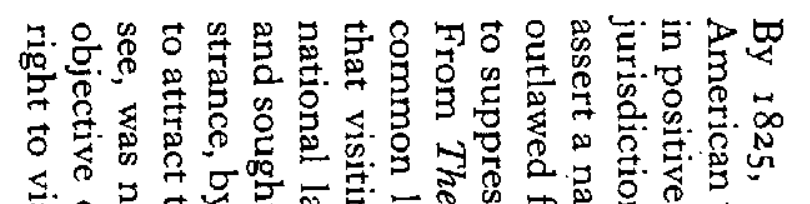

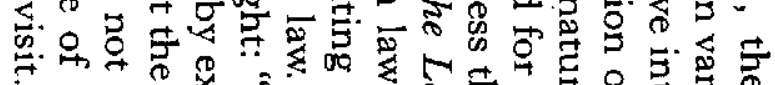

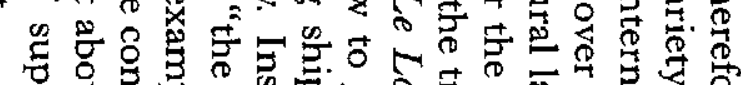

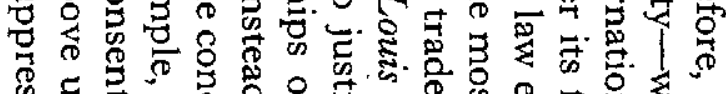

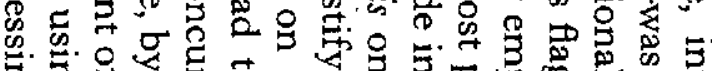

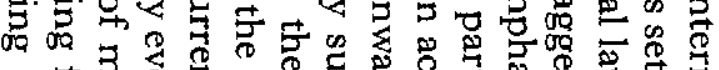

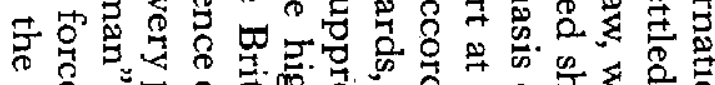

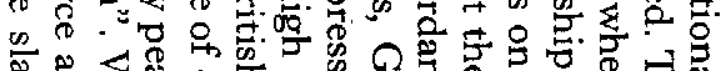

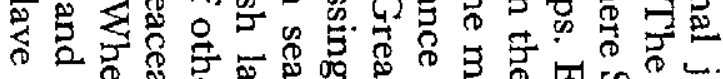
न 8 :

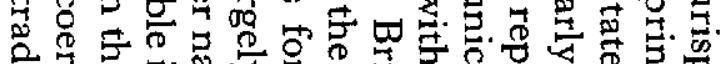
के

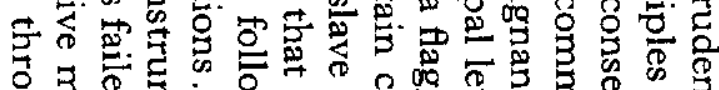

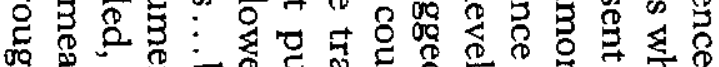

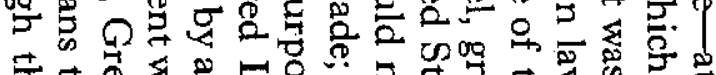
के

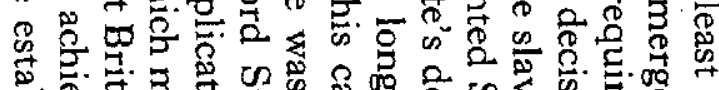

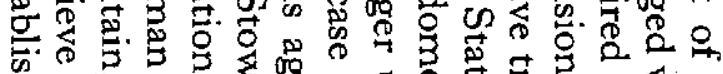

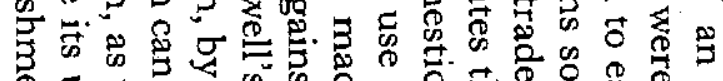

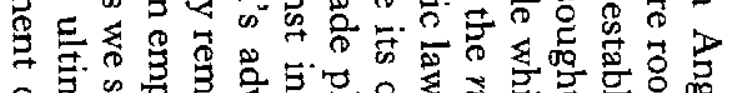

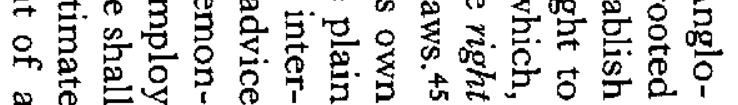

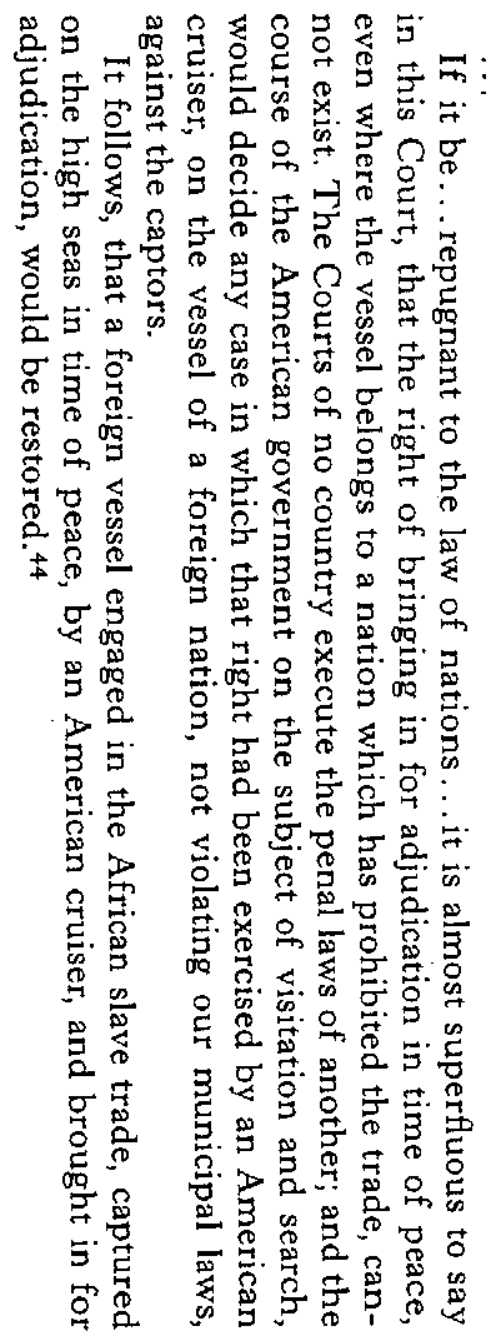




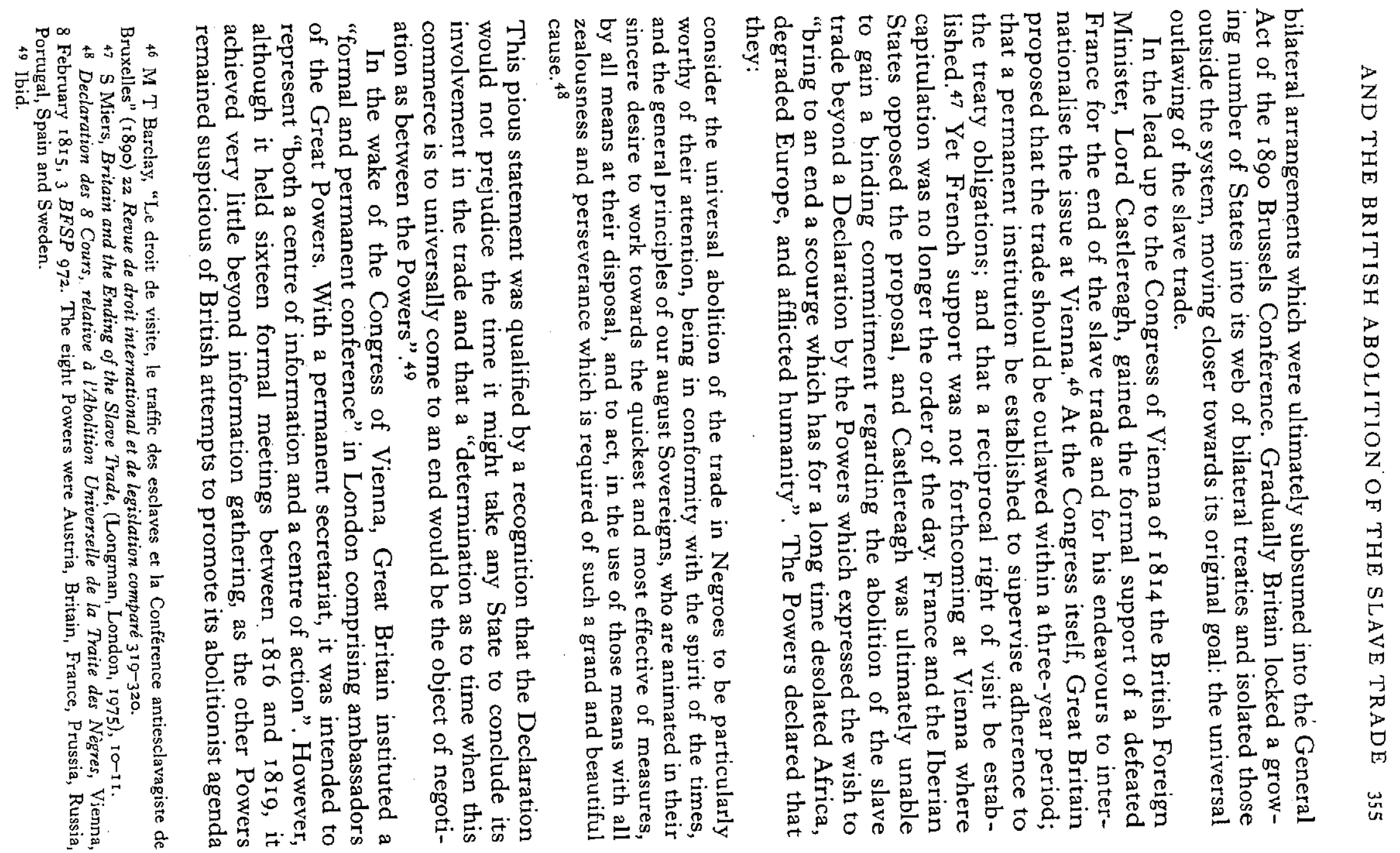




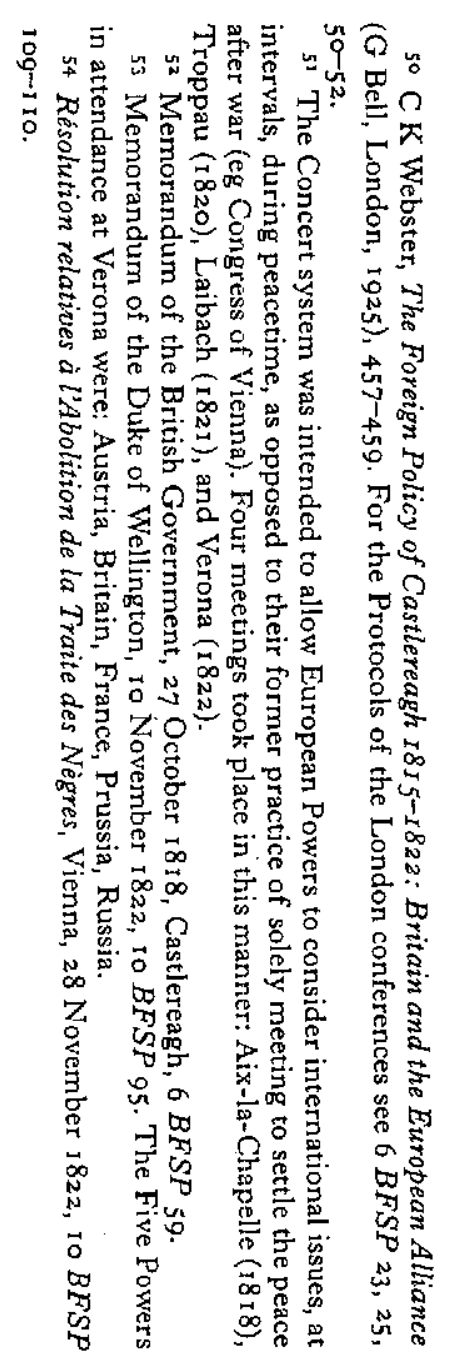

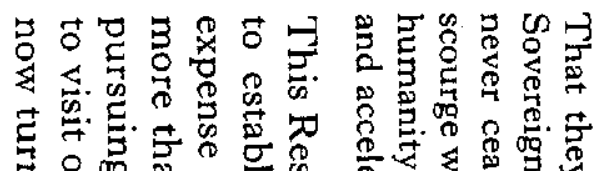

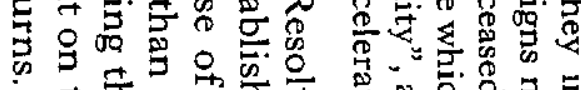

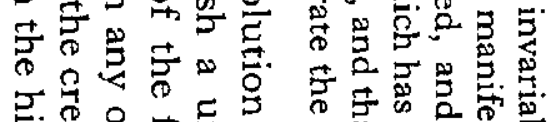

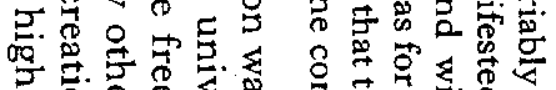

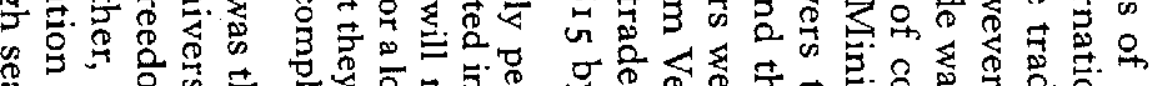

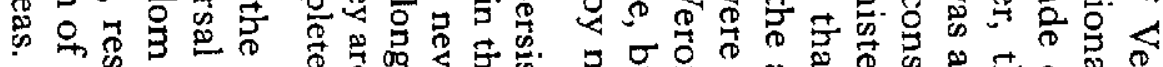
7 象品舟

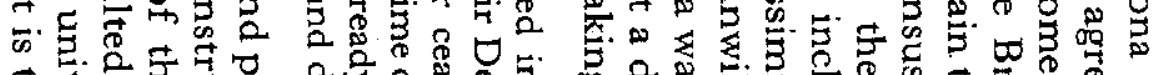

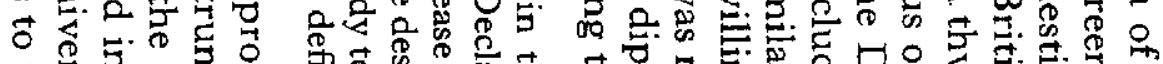
象 क.

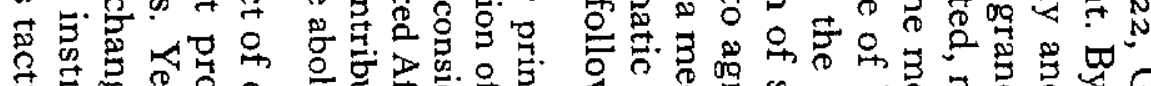

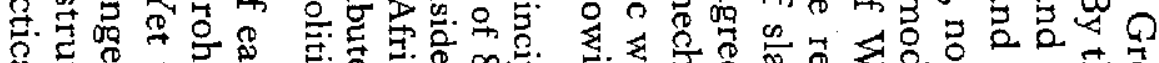

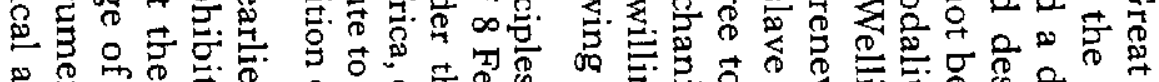

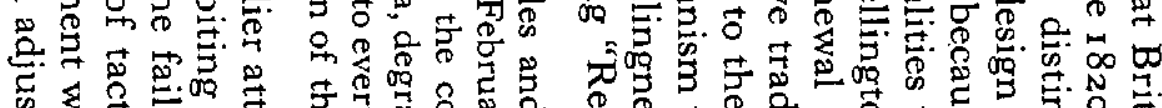

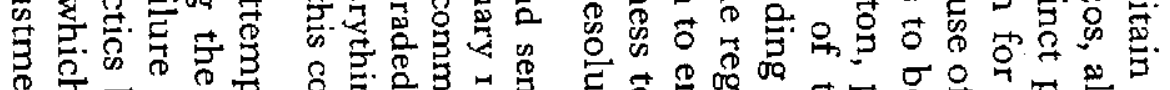

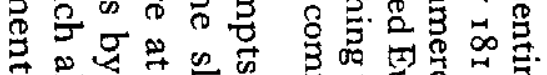
हो $0<\frac{2}{0}$ .

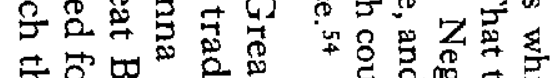
政.

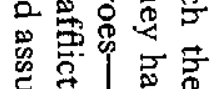

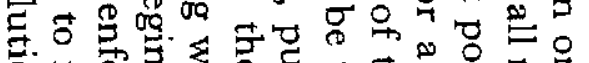

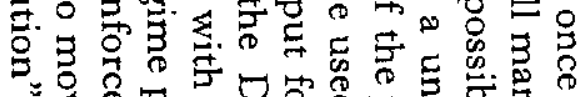

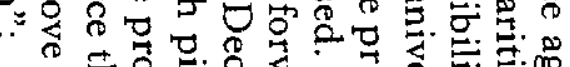

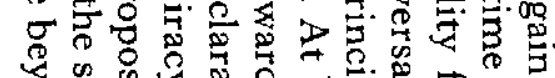

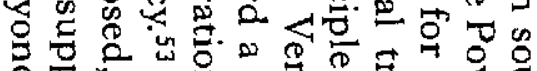

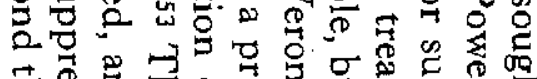

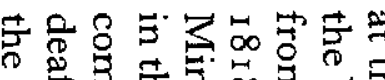
$\breve{s}_{\alpha}$

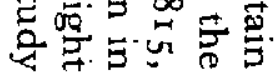
후운

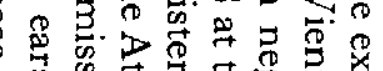

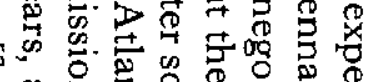

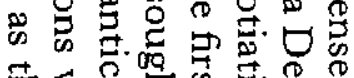

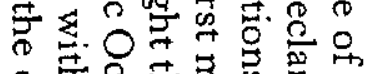

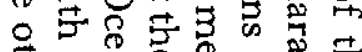

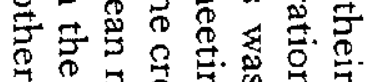
गृ

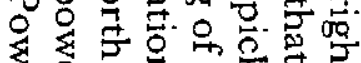

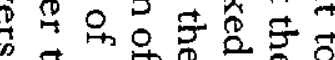
氶

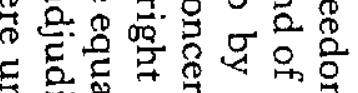

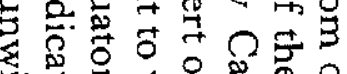

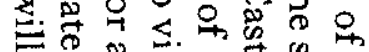

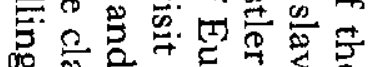

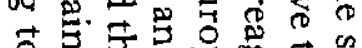

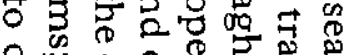

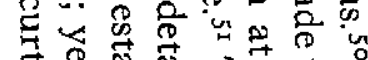

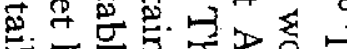

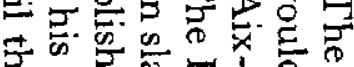
क.

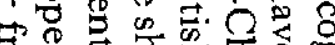

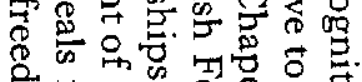

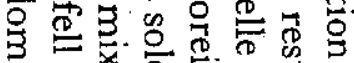

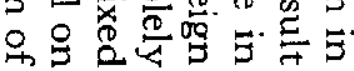




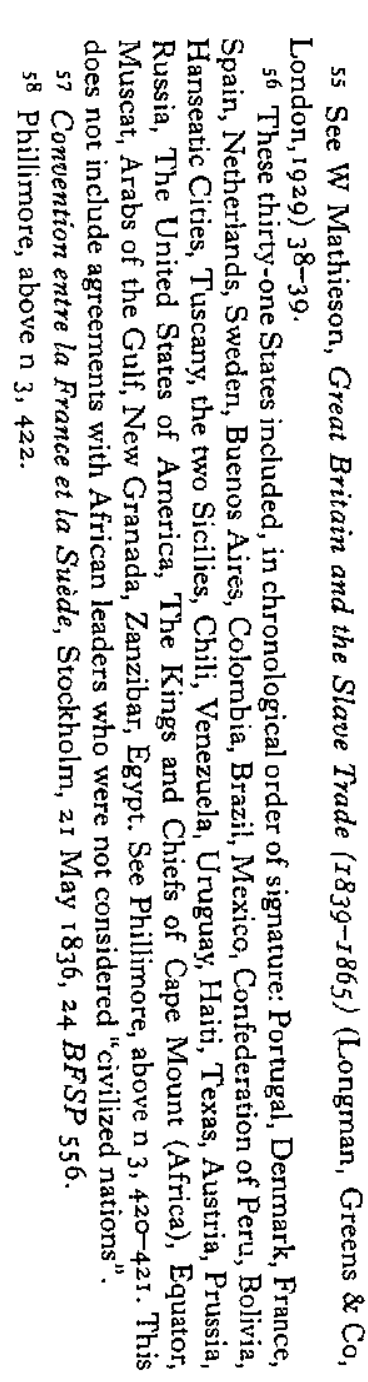

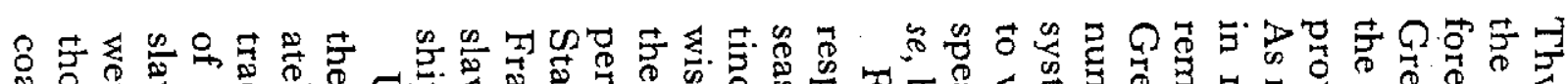

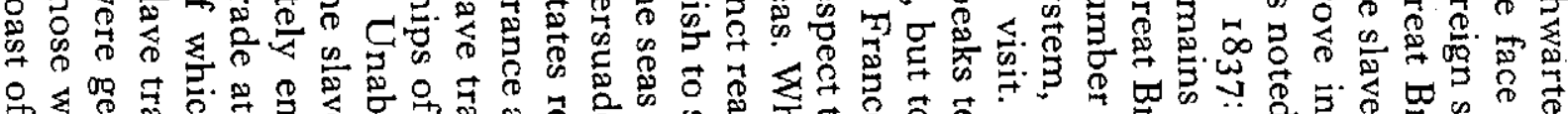

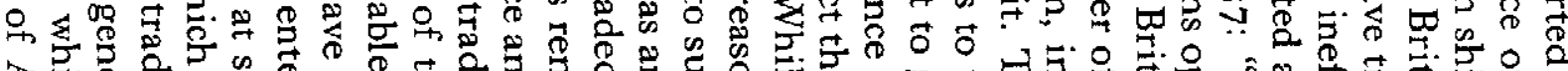

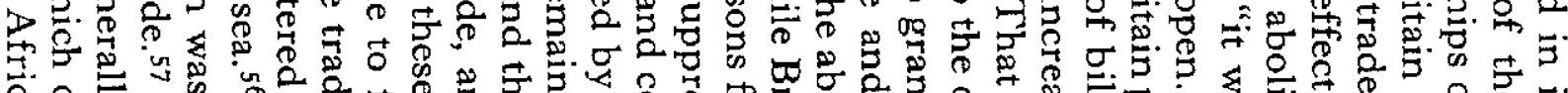

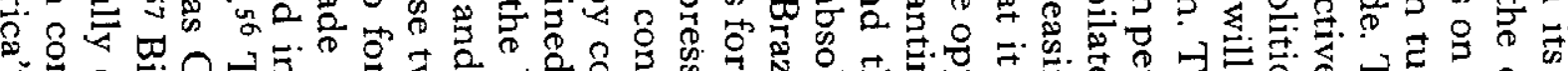

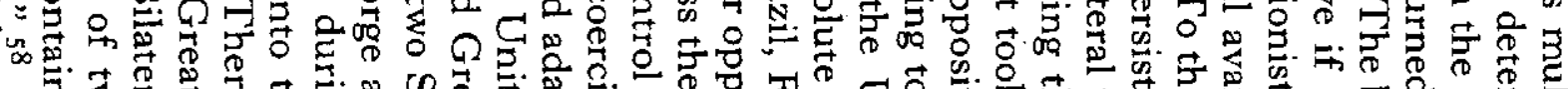

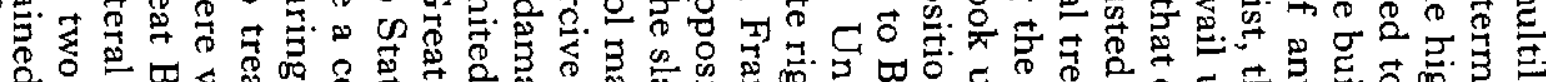

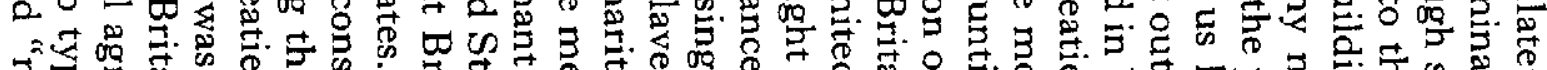
उ

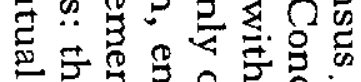

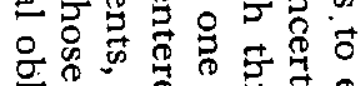

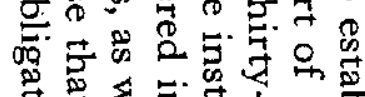

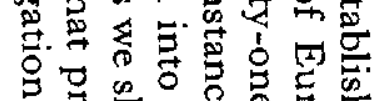

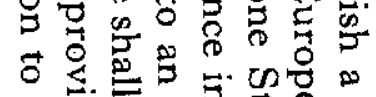

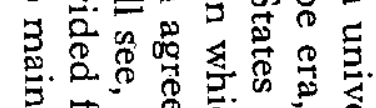

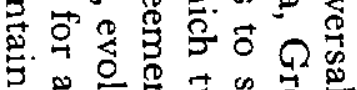
क

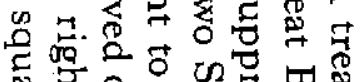

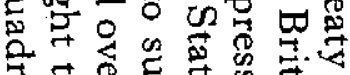

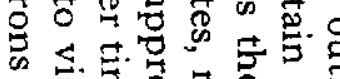

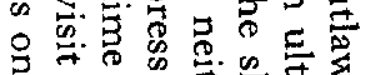

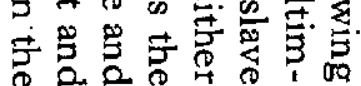

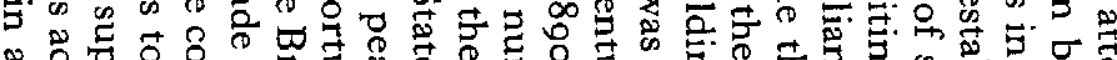
రิ

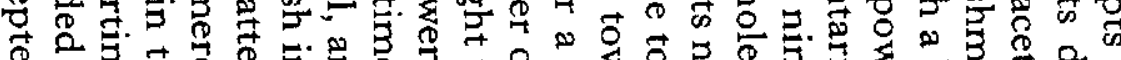

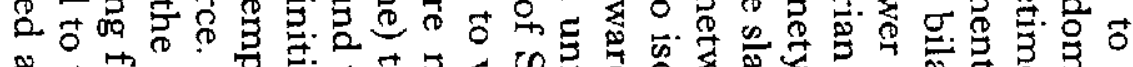

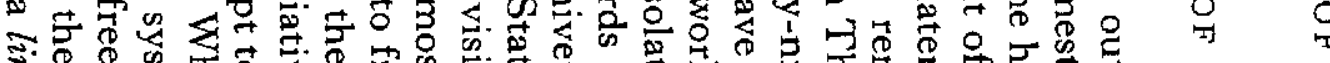

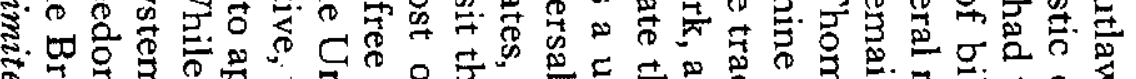

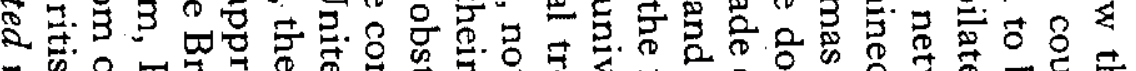

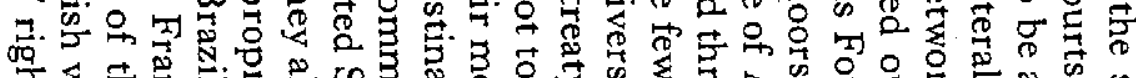

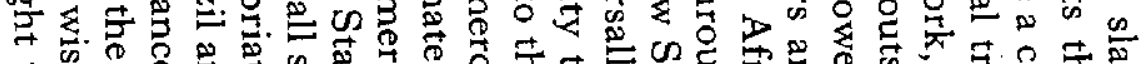
व $\begin{gathered}5 \\ 0\end{gathered}$

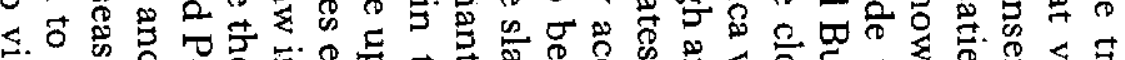

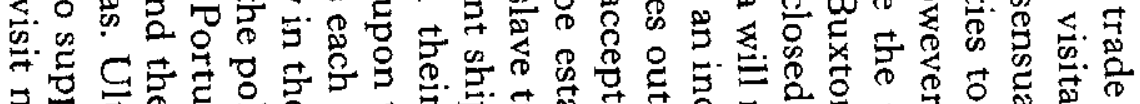

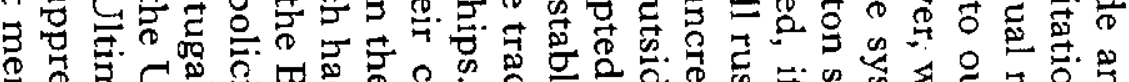

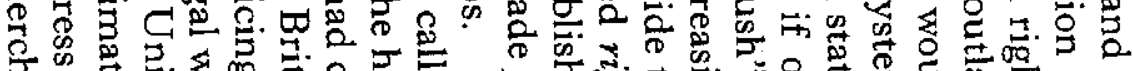

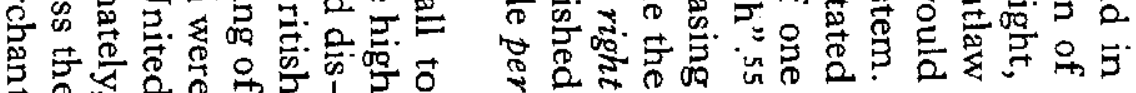




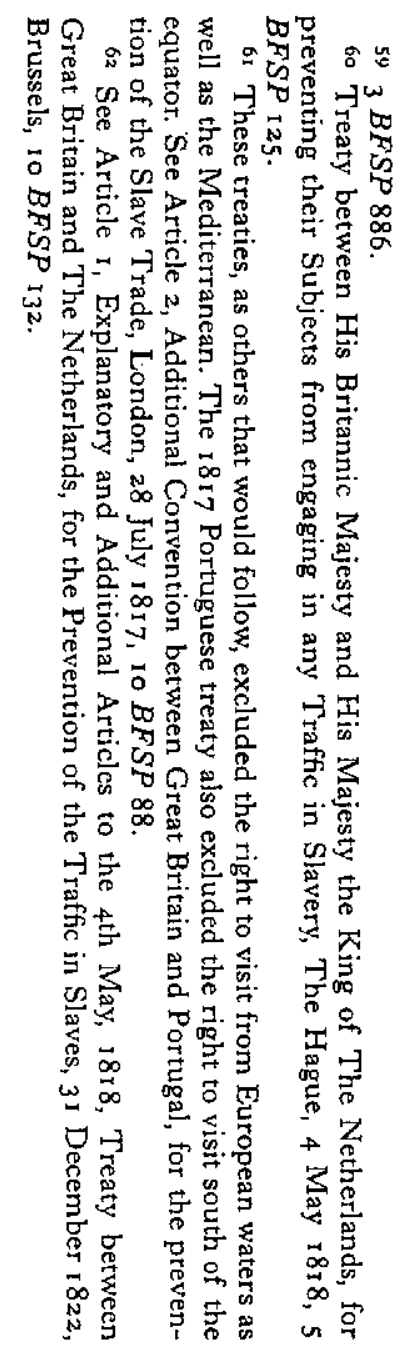

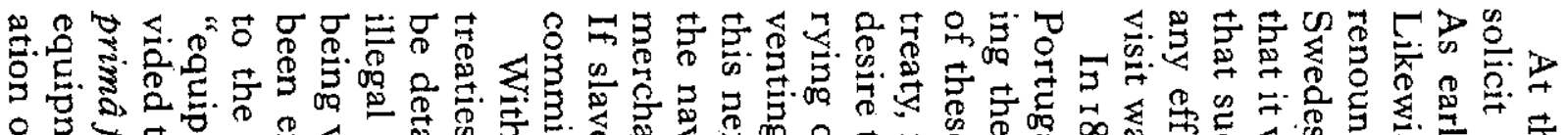

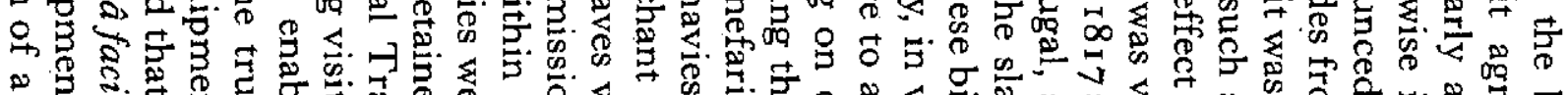
2

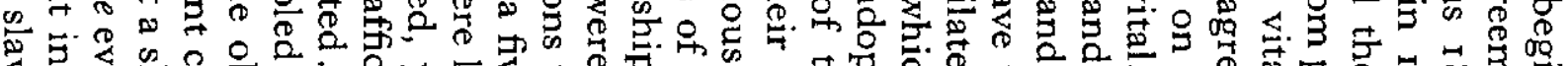

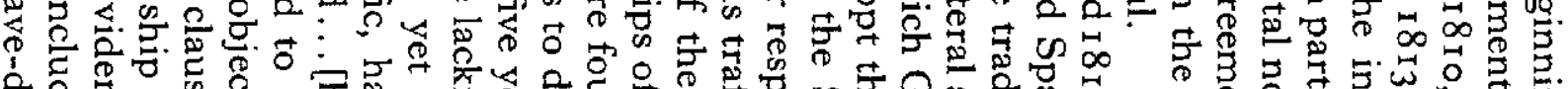

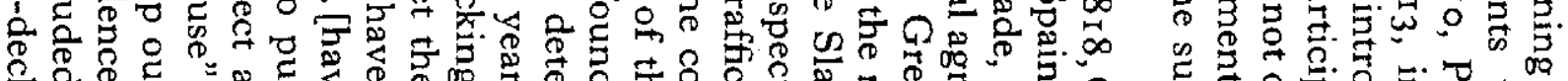

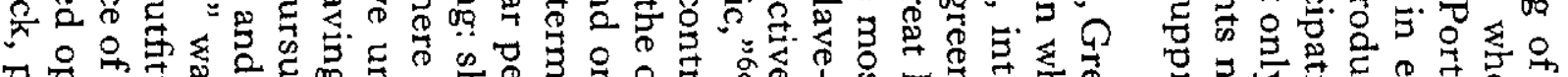

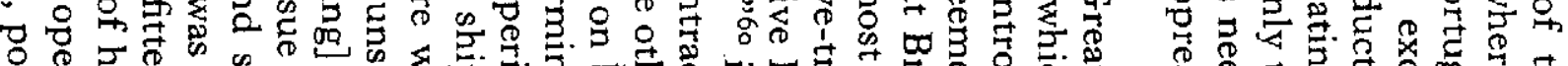

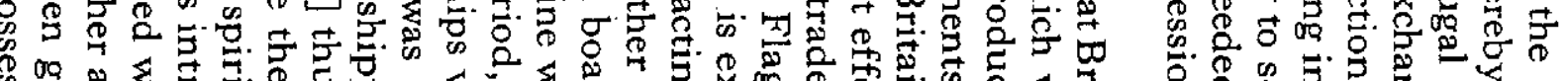
留

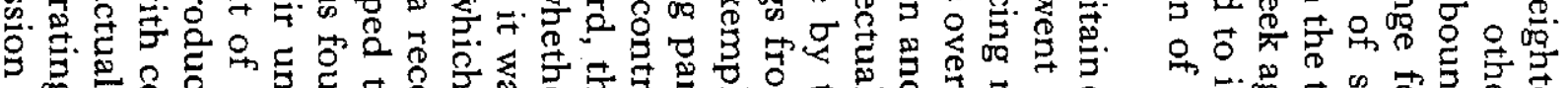

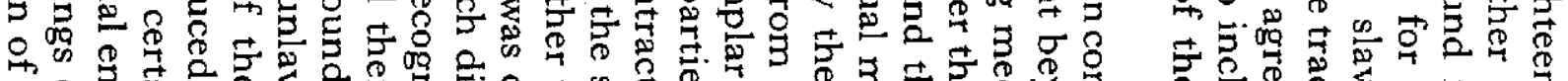

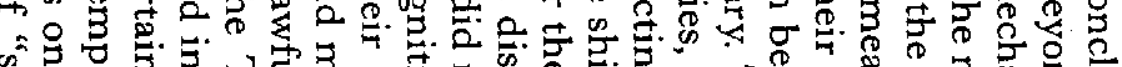

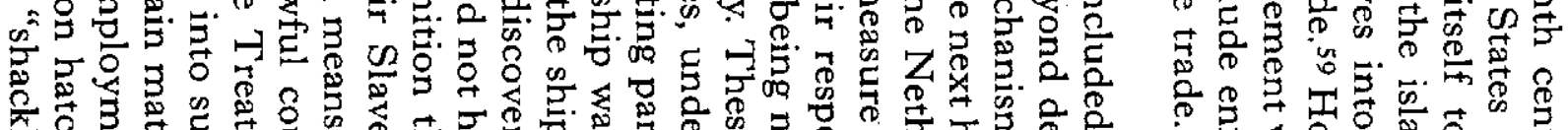

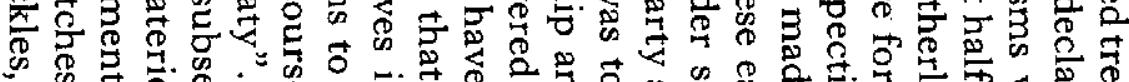

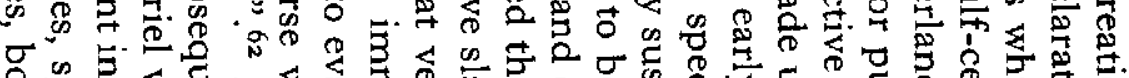

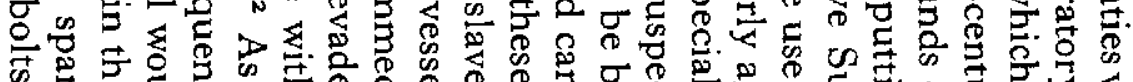

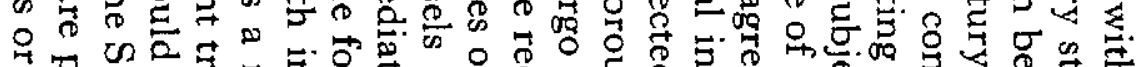

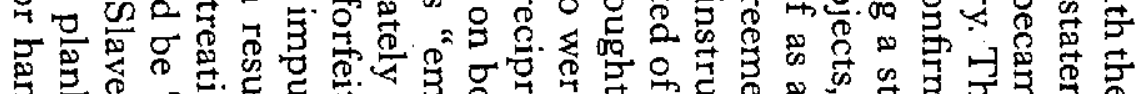

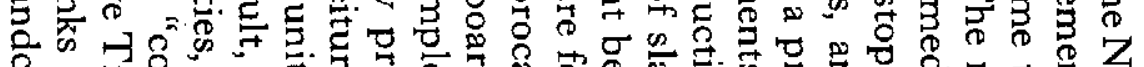

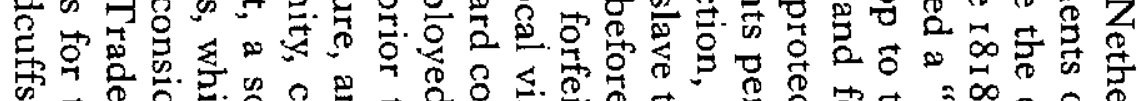

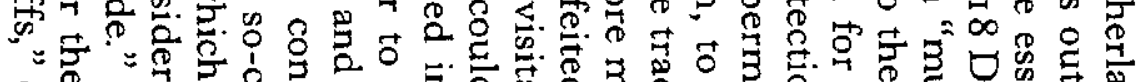

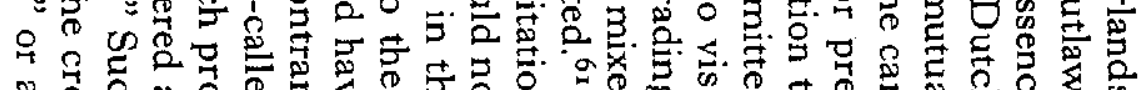

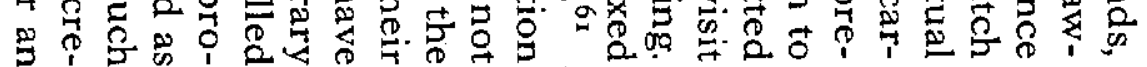

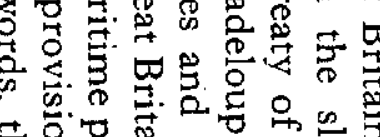
के

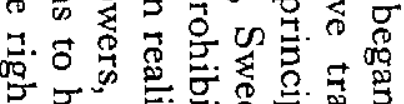

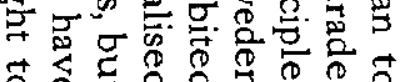




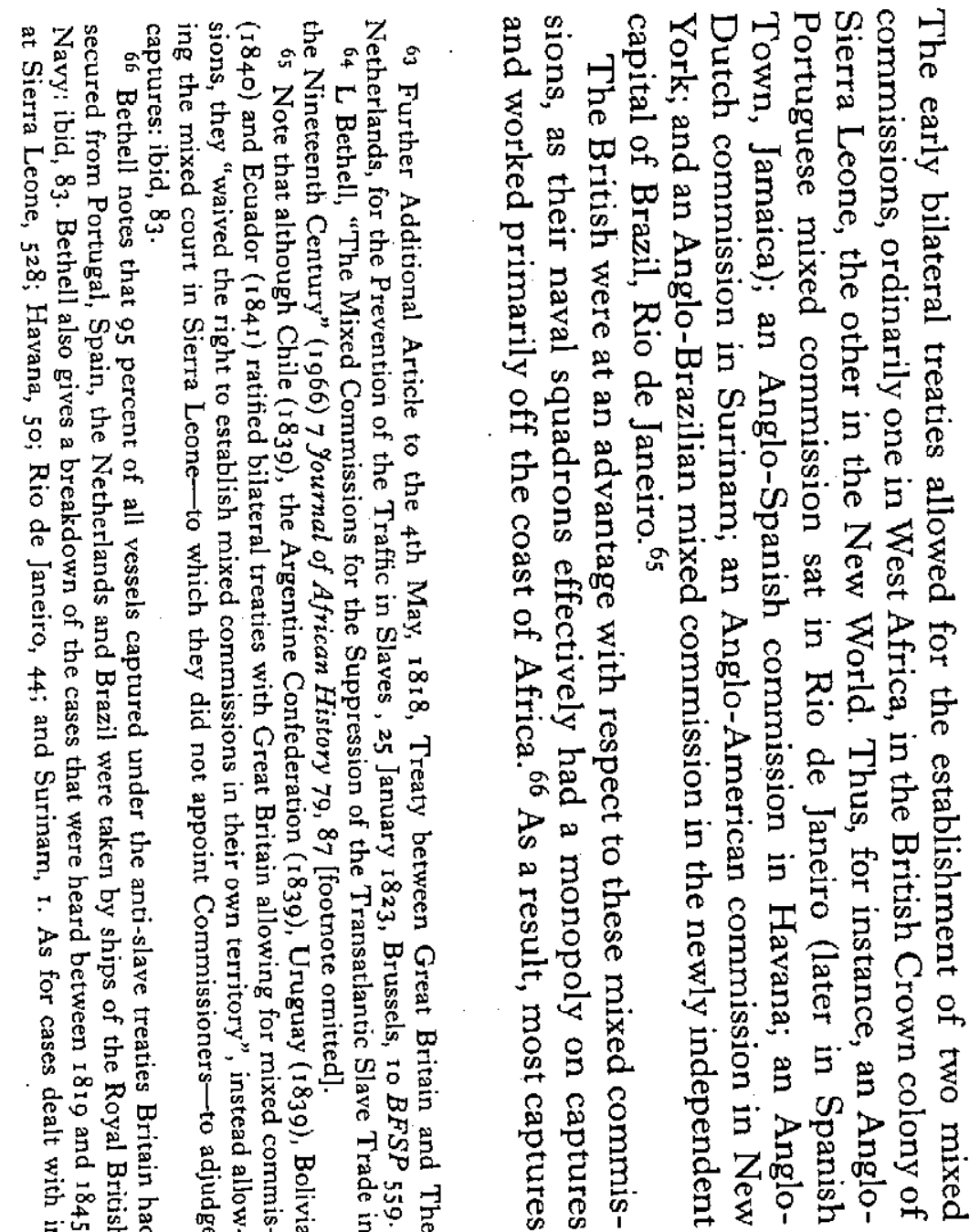

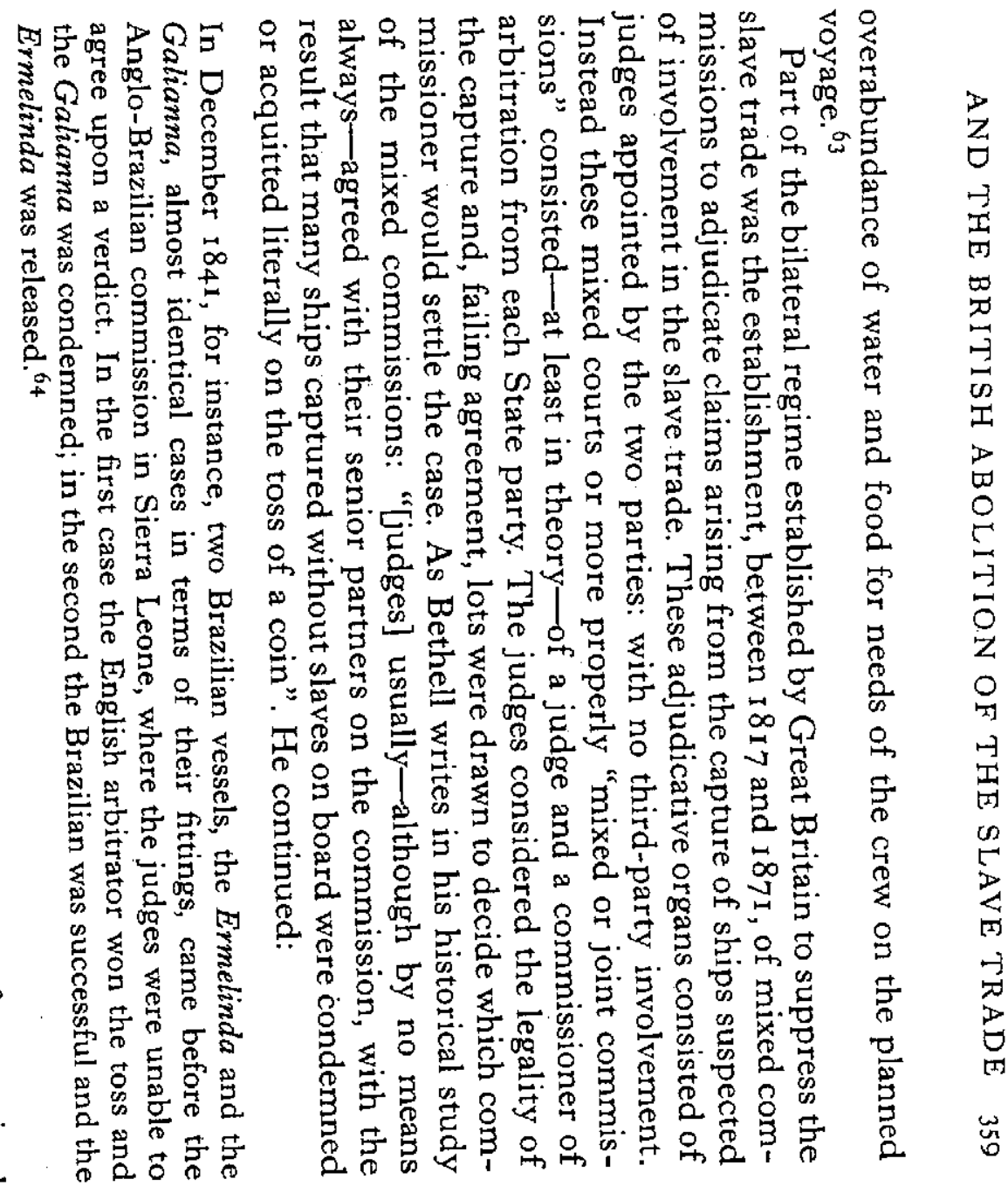




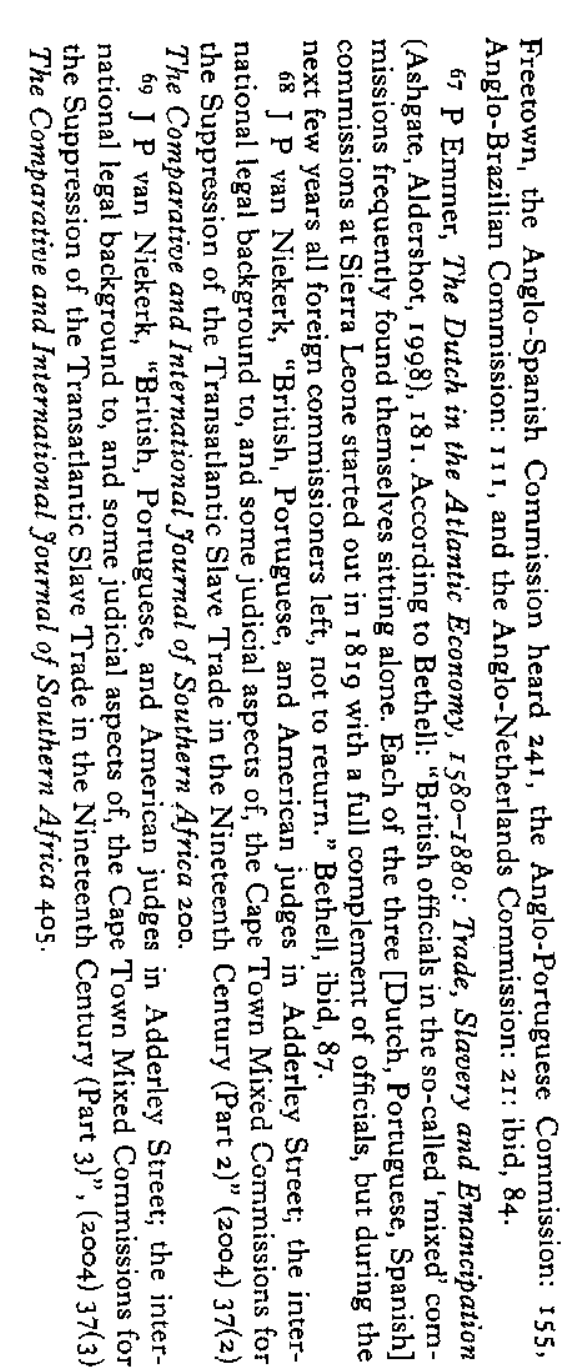

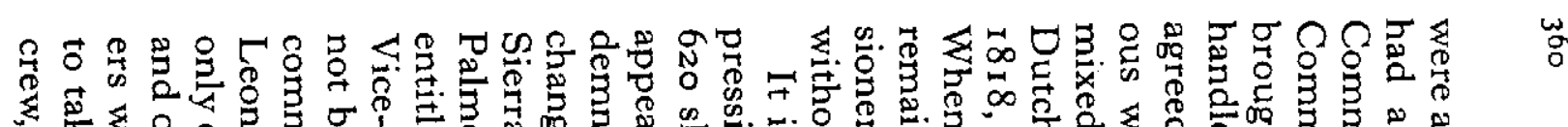

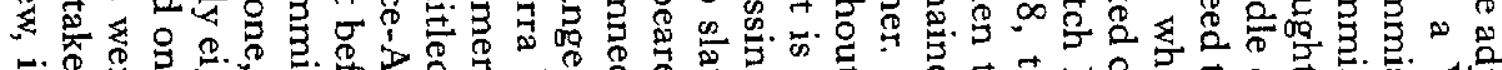
ㄱ.

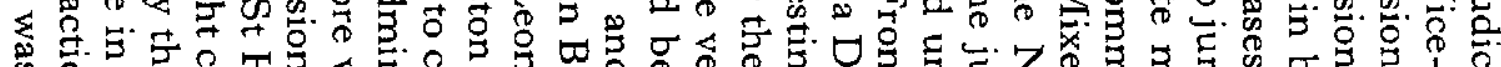

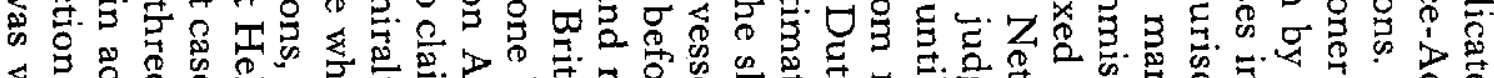

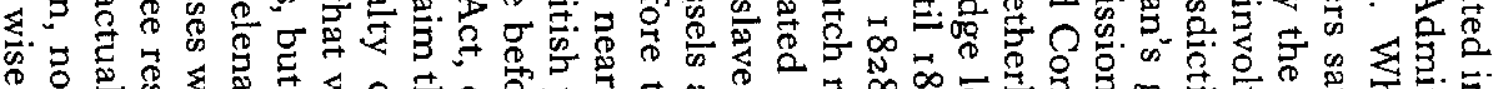

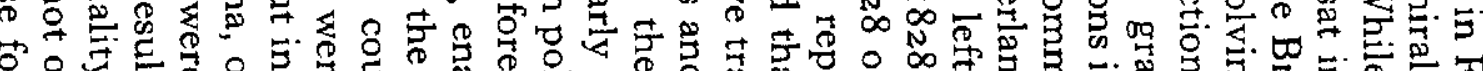

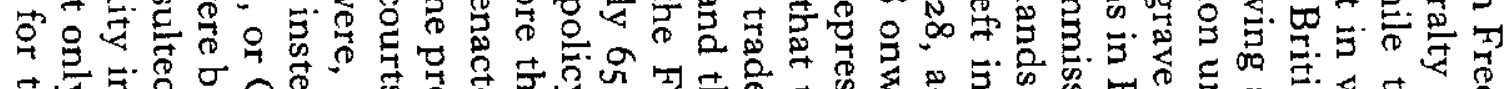

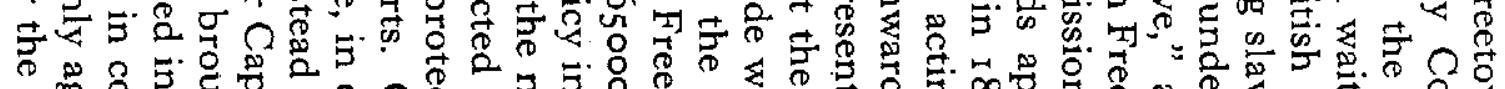
象. 包

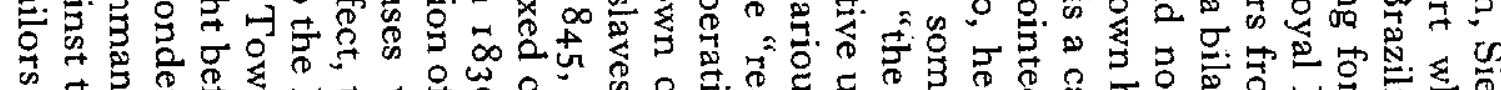

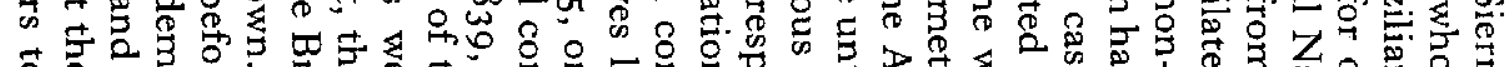

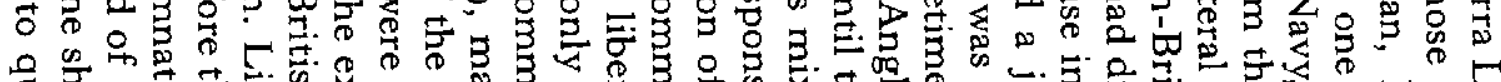
至.

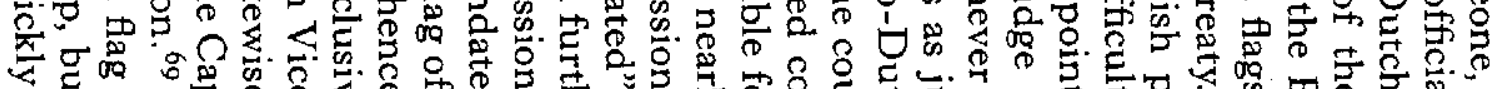

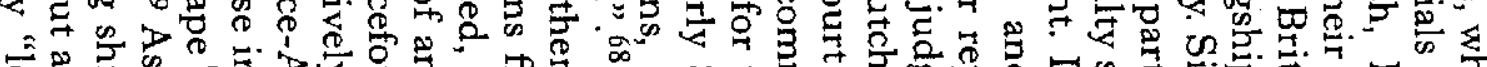

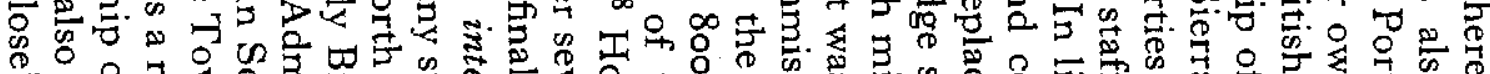

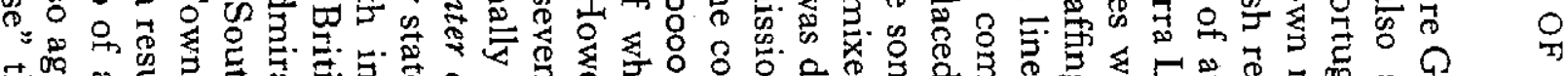

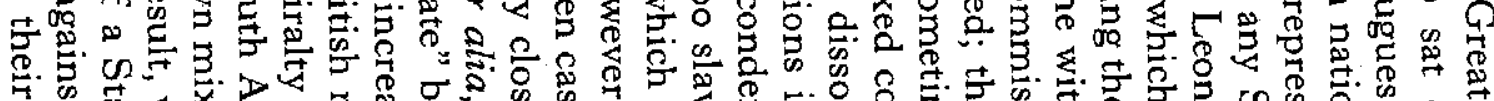

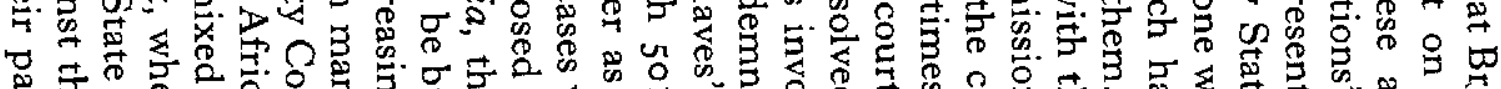

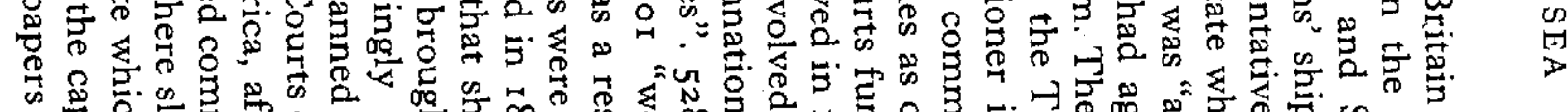

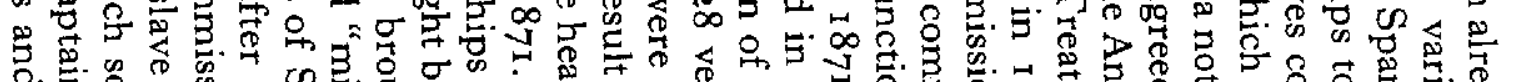

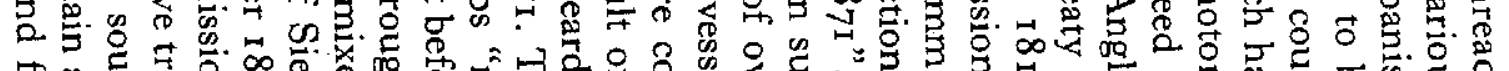

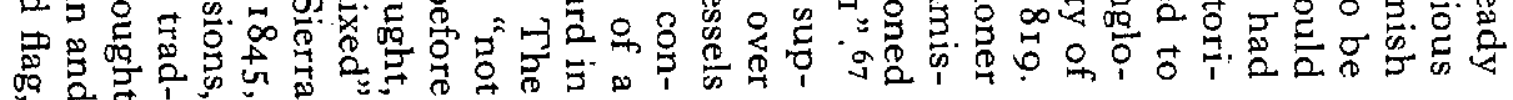



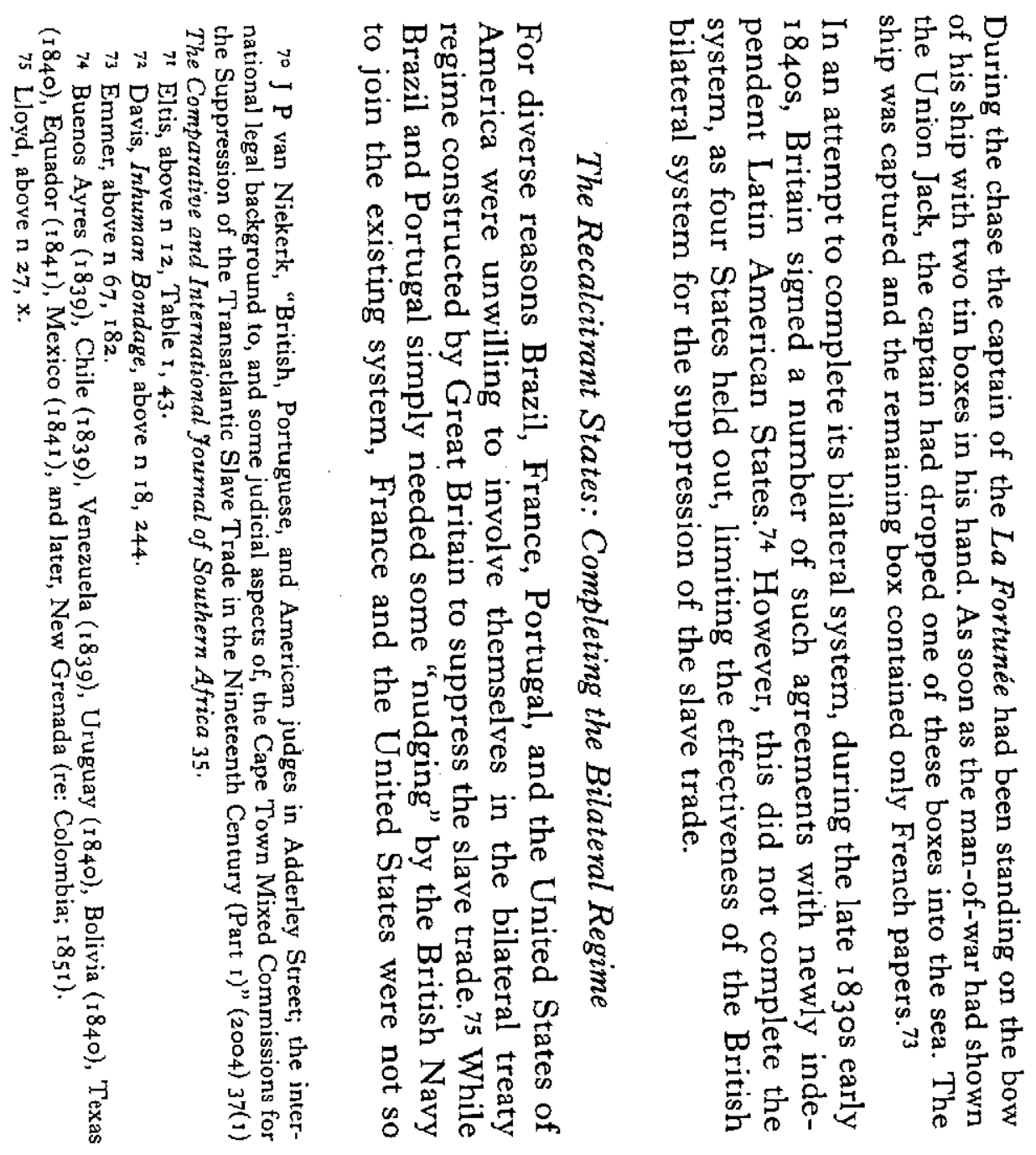

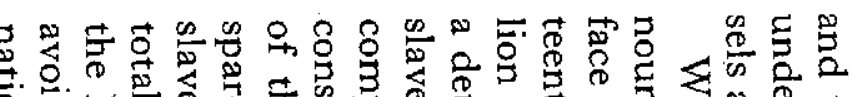

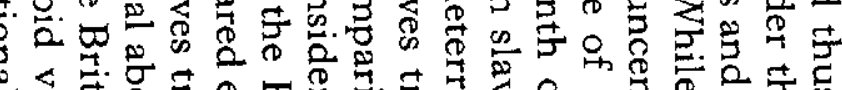

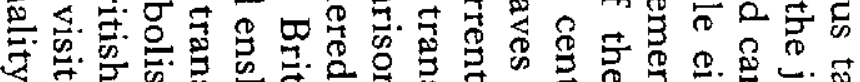

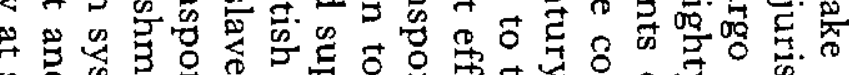

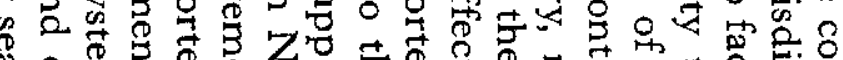

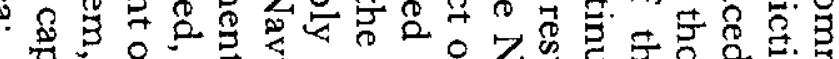

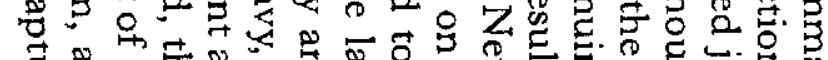

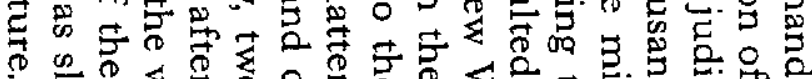

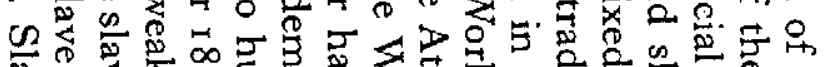

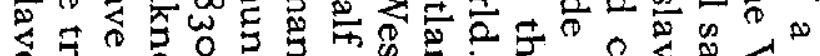

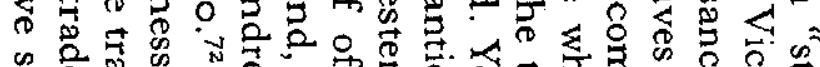

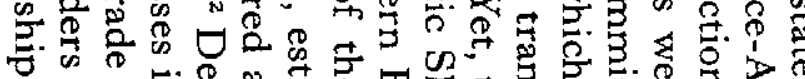

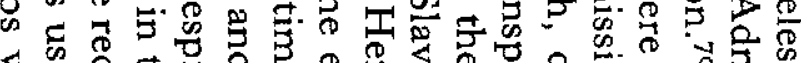

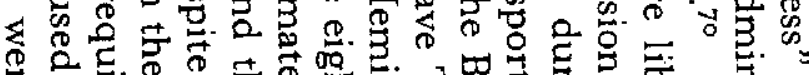

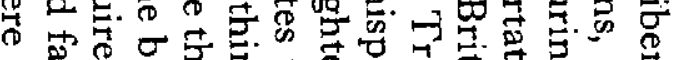

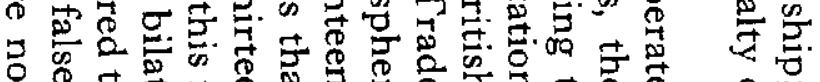

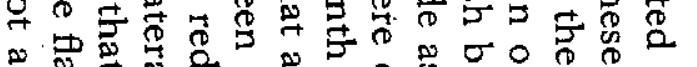

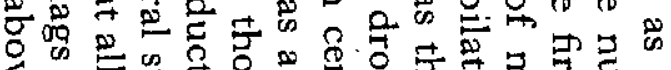

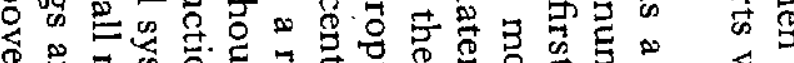

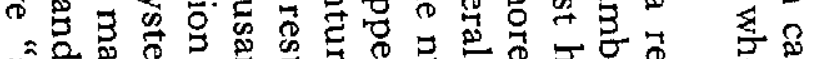
है क्م.

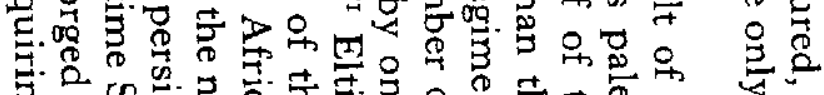

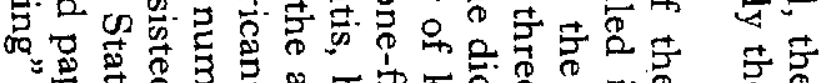

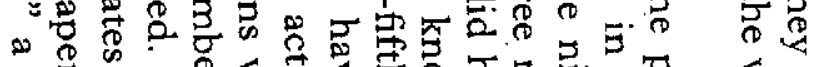

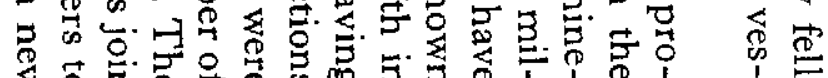




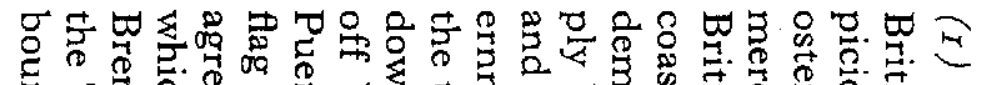

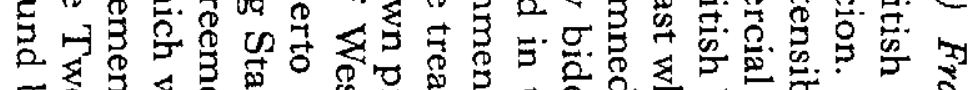

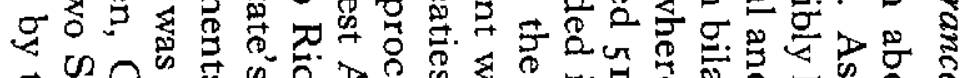

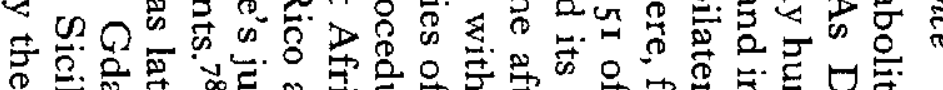

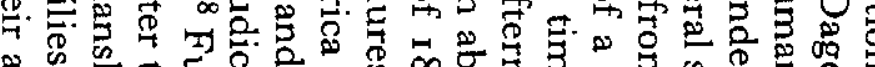

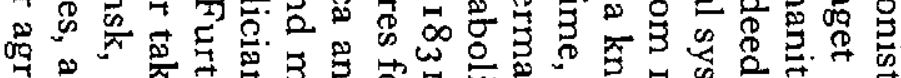

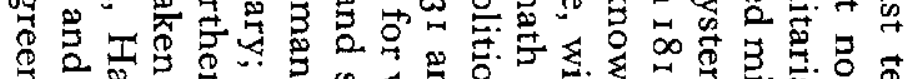

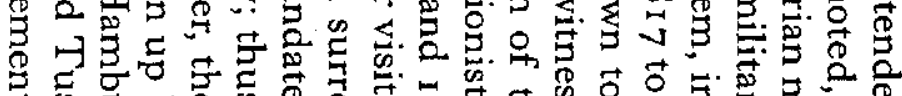
कि

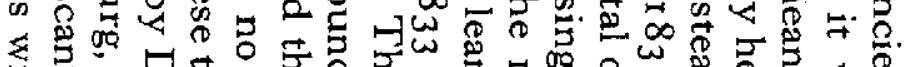

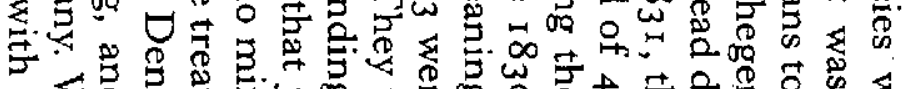

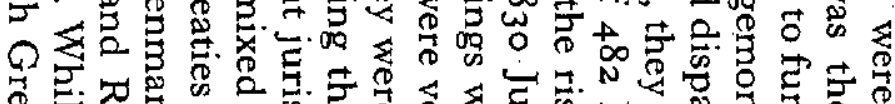

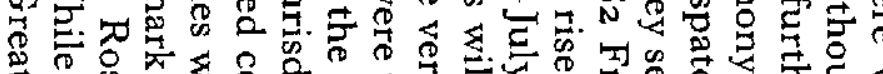

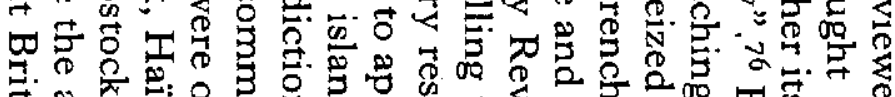

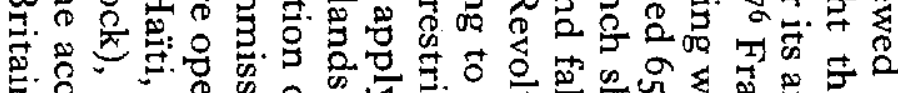
S w

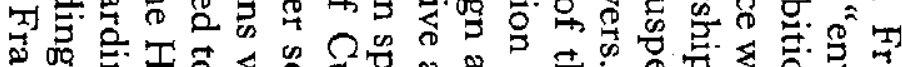
की

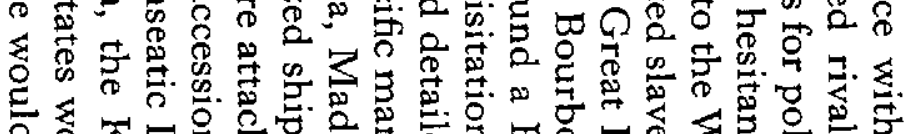

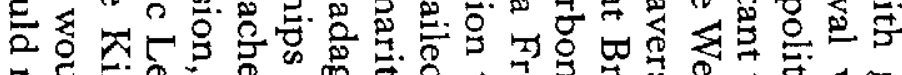

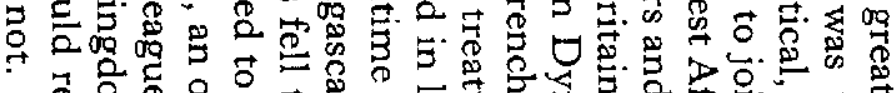

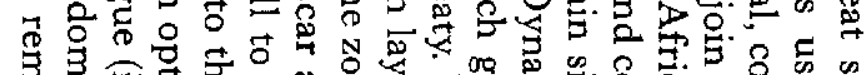

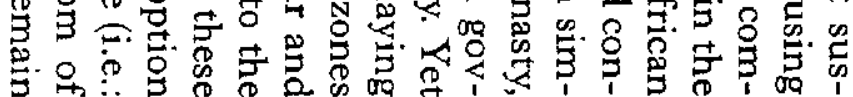

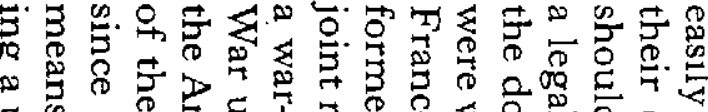
5.

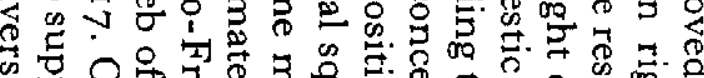
要家

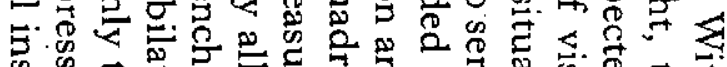

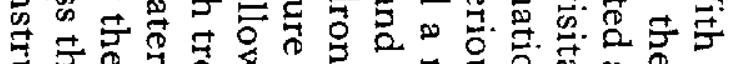

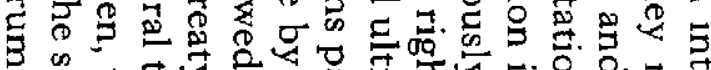

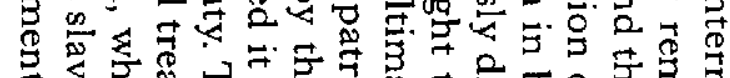

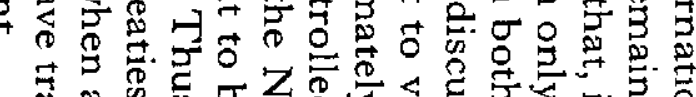

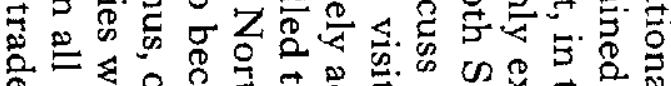

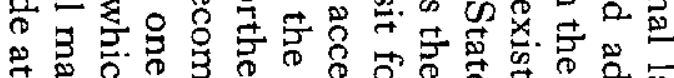

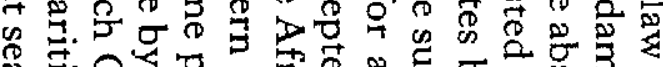

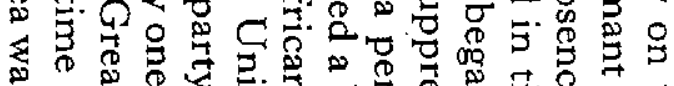

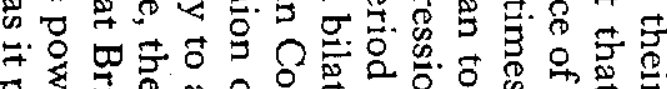

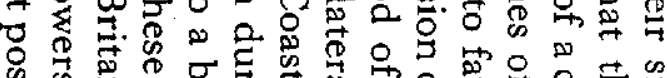

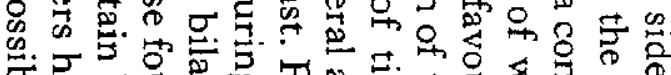

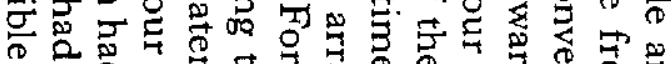

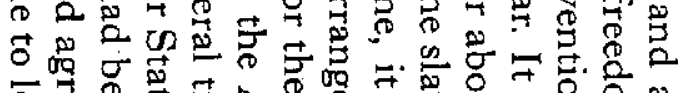

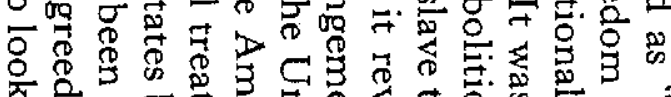

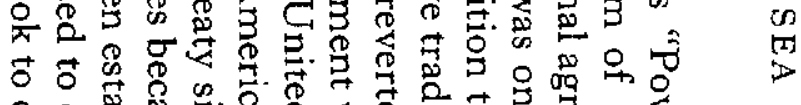

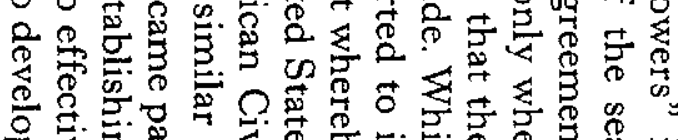

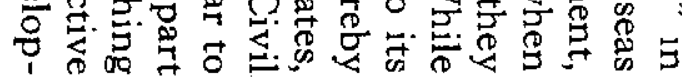




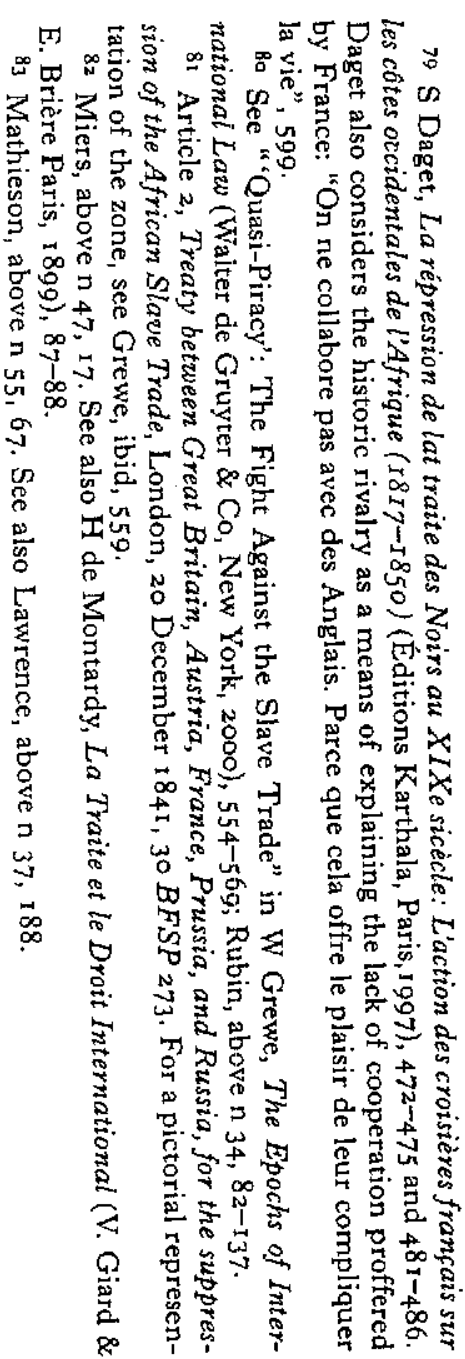

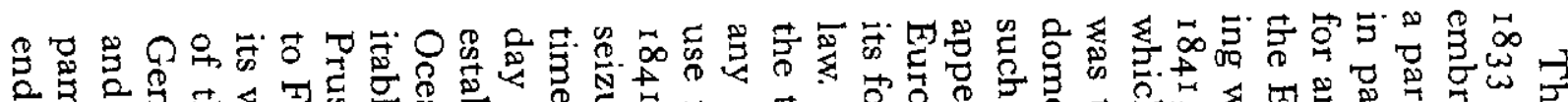

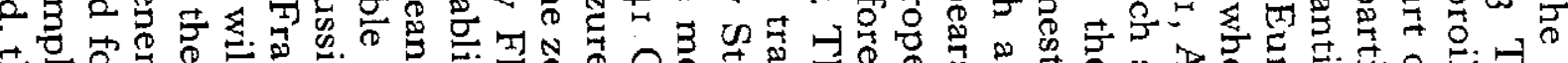

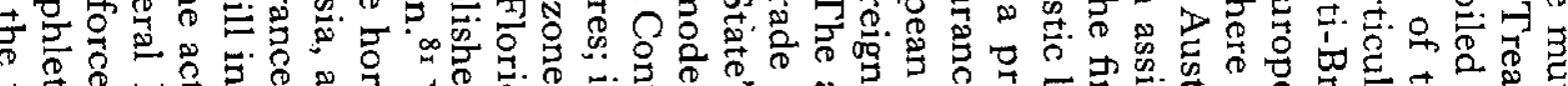

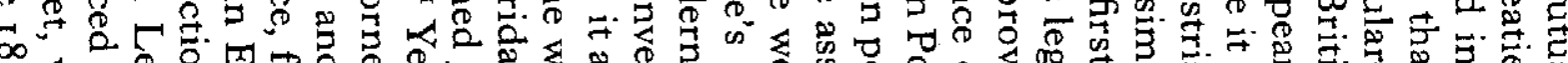

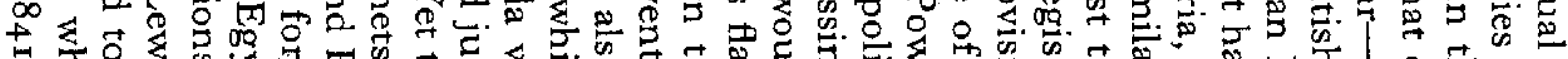

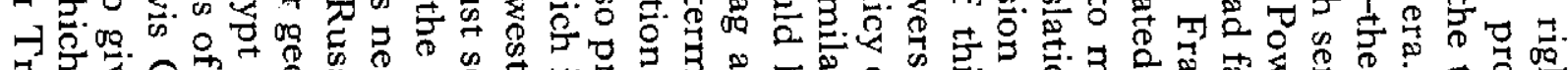

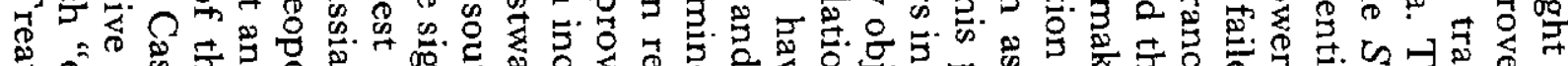

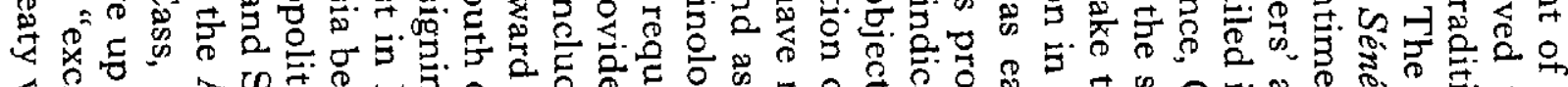

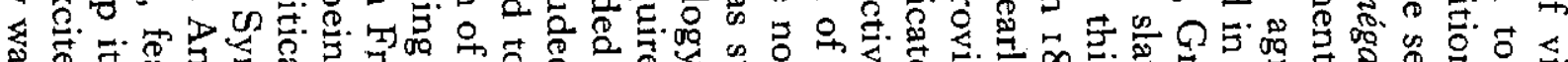

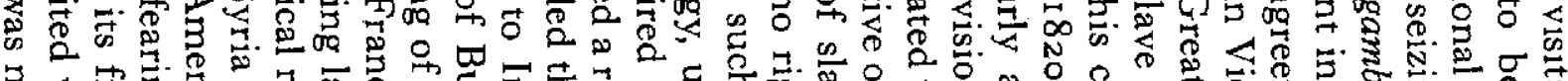

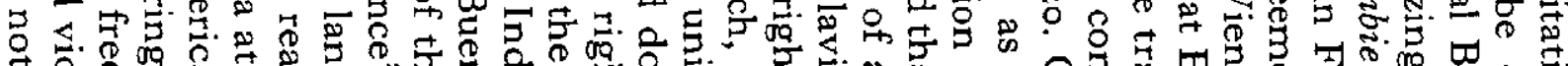

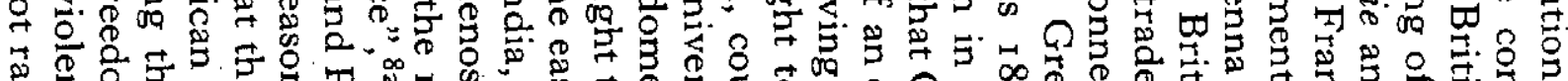

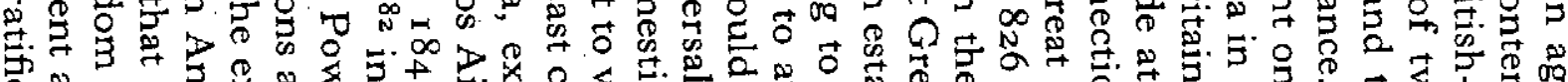

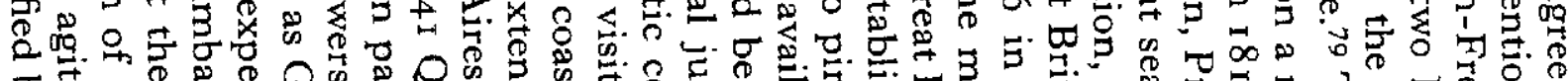

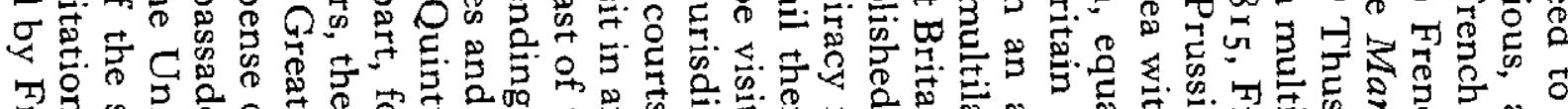

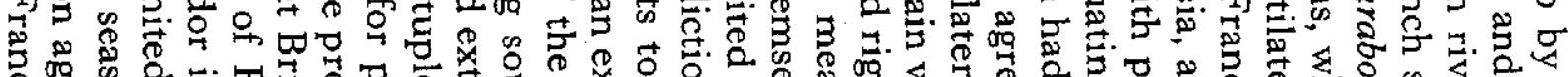

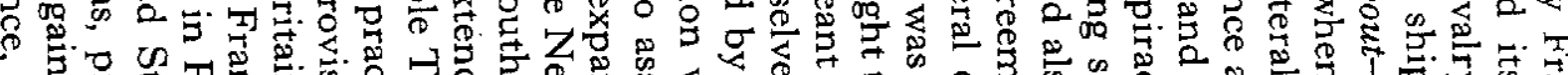

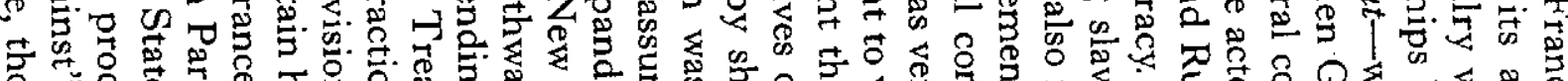

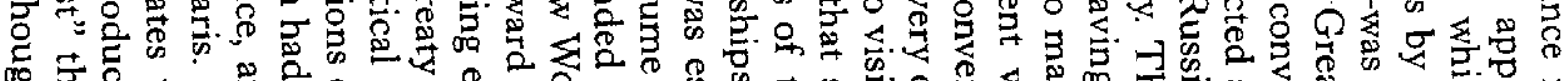

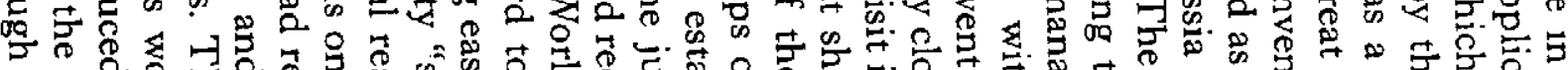

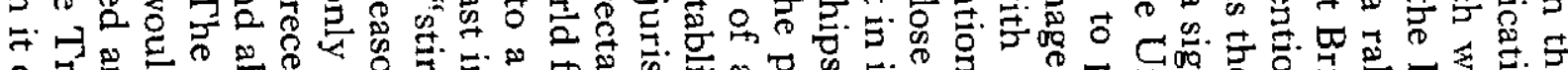

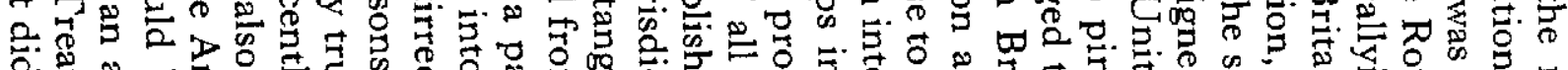

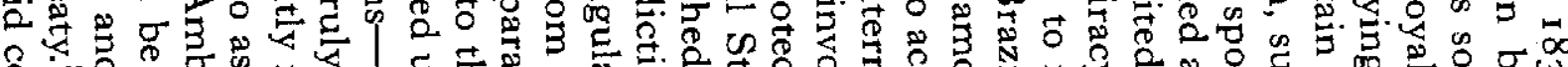

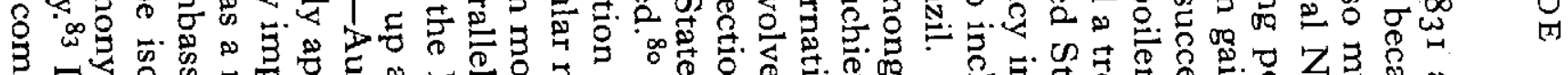

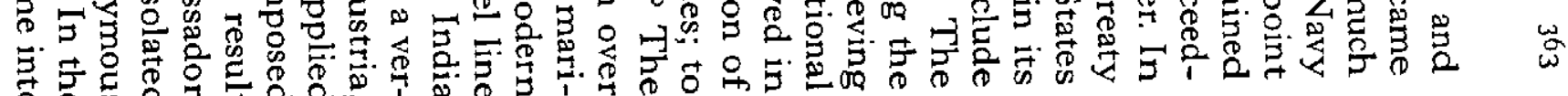




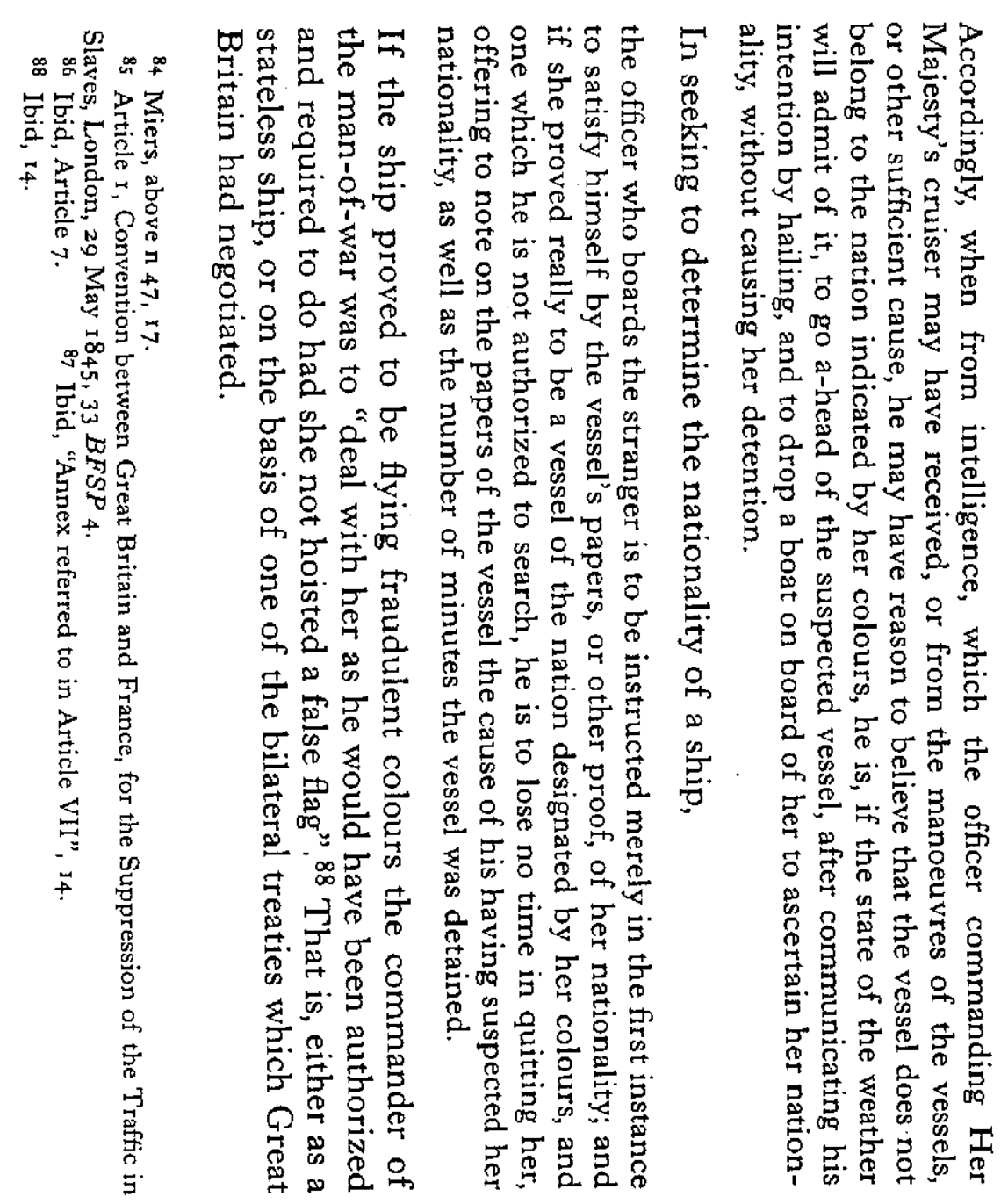

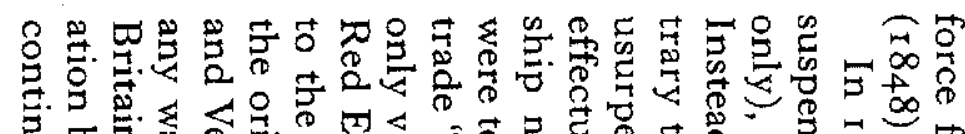

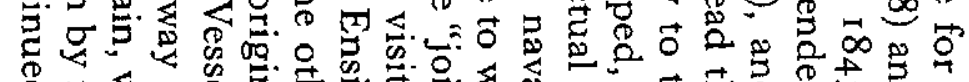

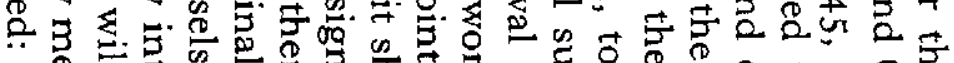
筮

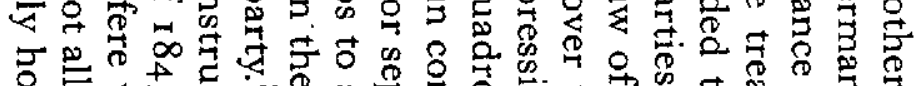
क.

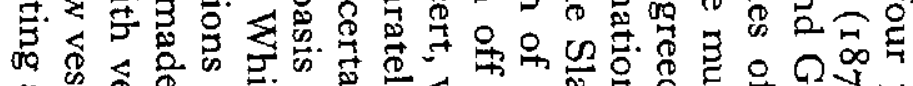

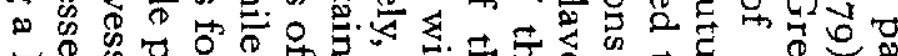

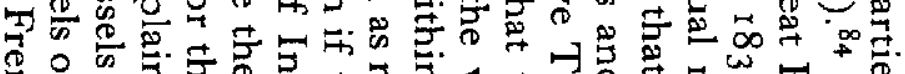

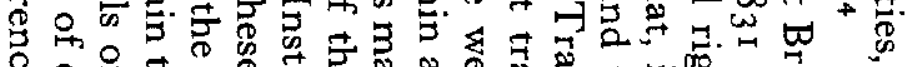

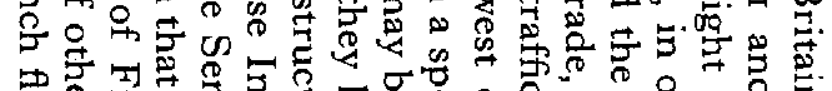

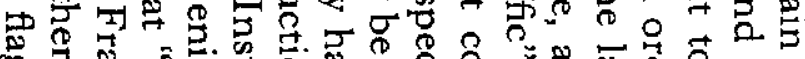

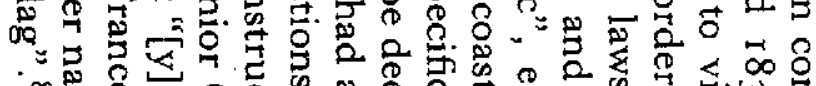

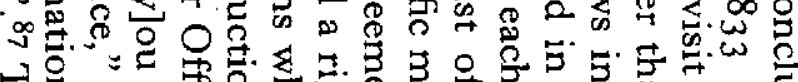

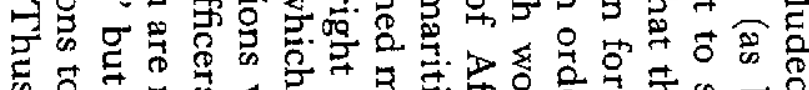

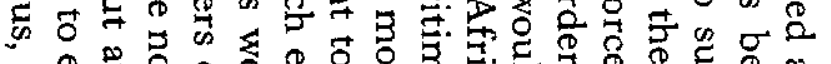

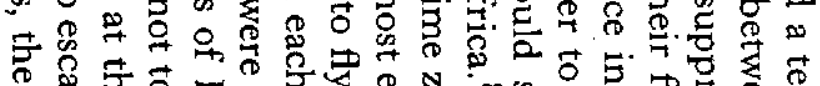

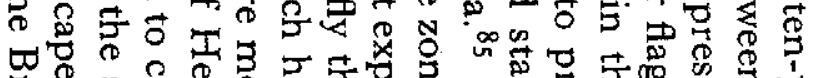

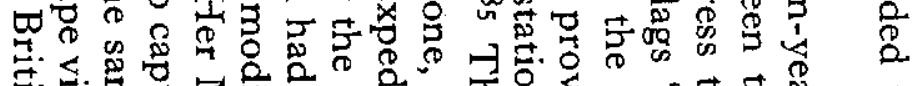

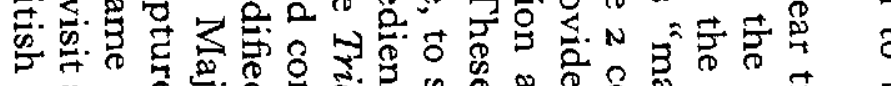

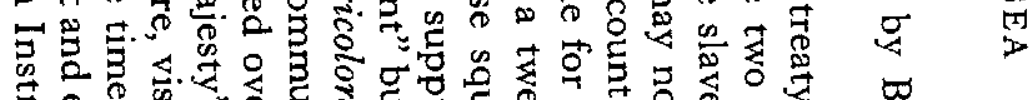

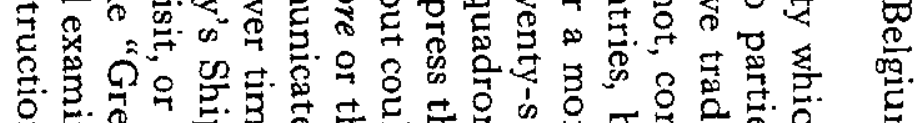
恶 Z 界 TI 甹 R 


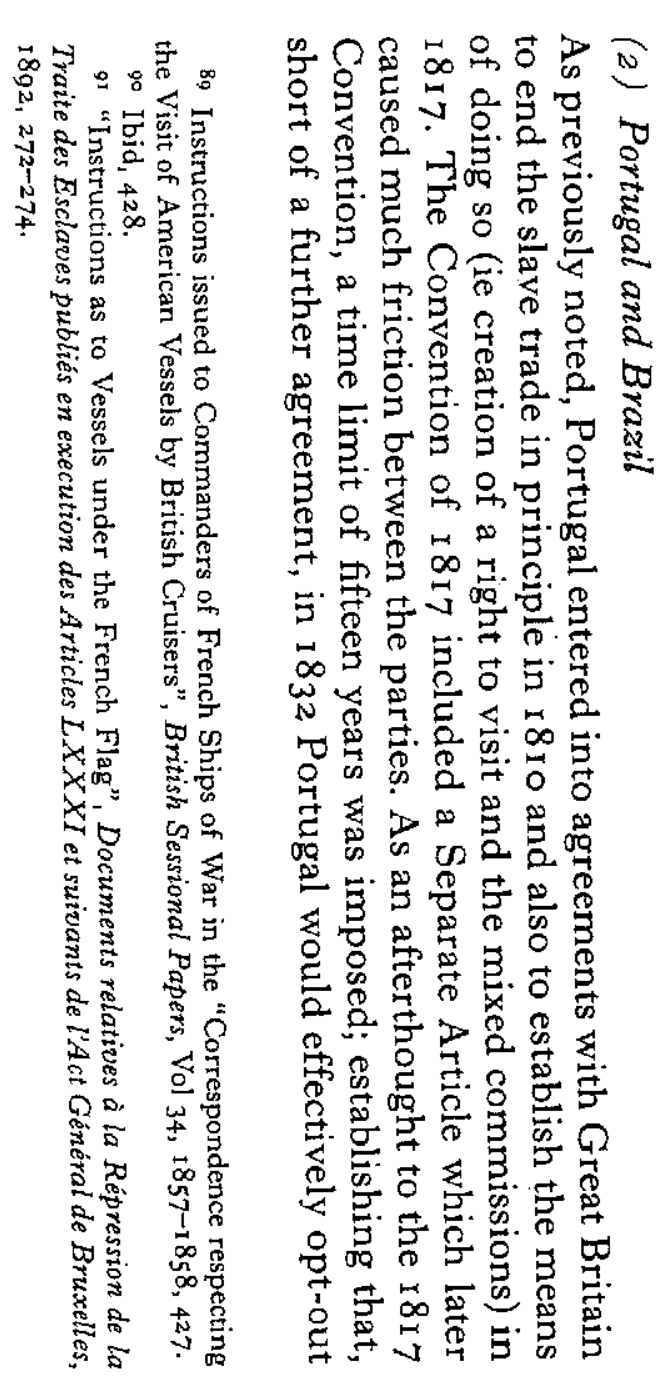

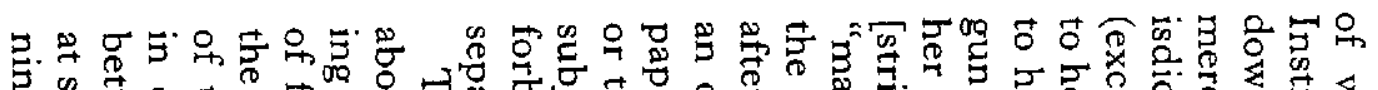

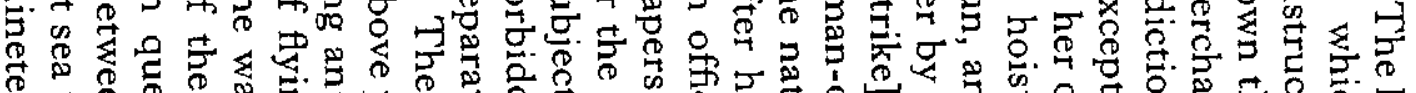

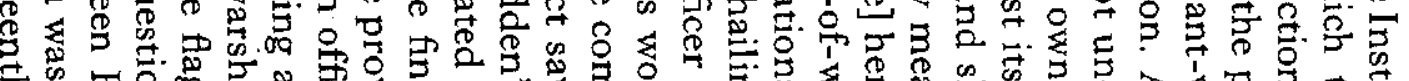

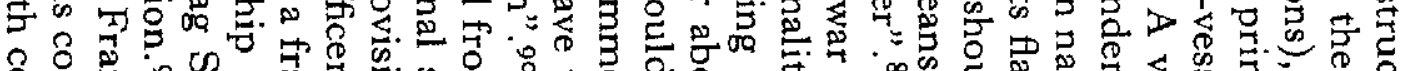

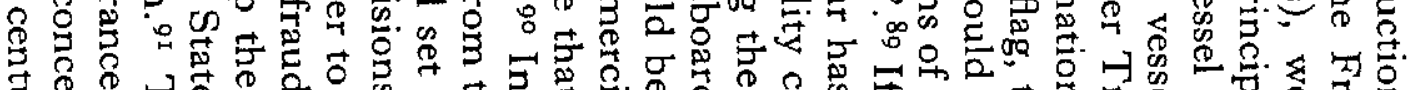

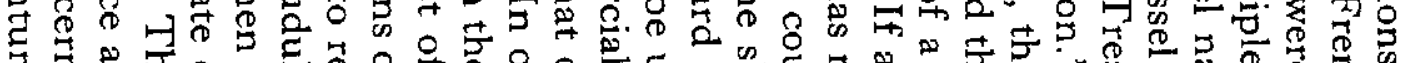

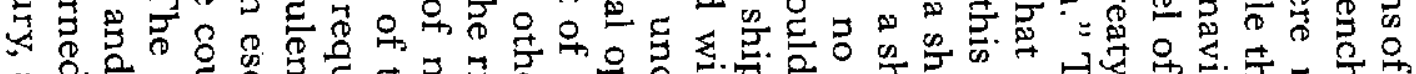

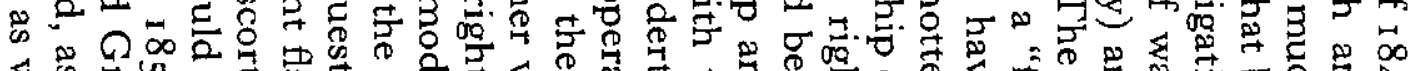

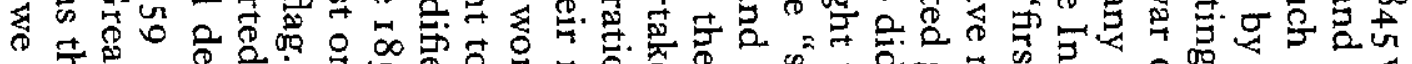

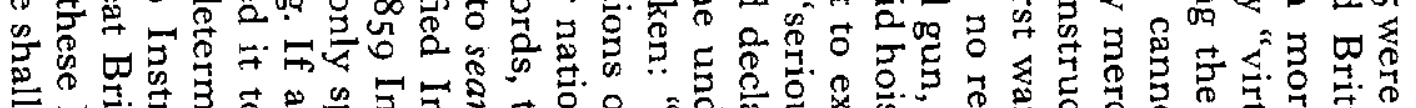

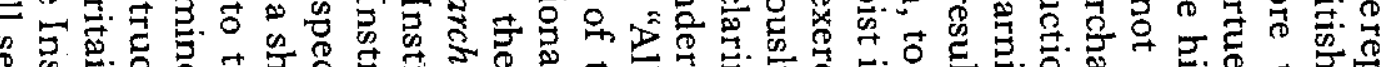

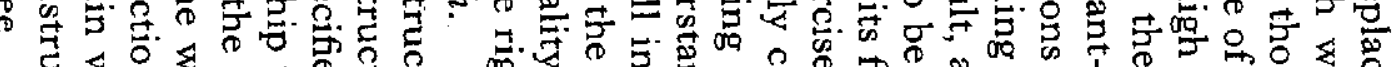

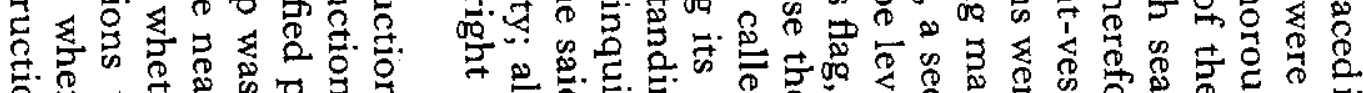

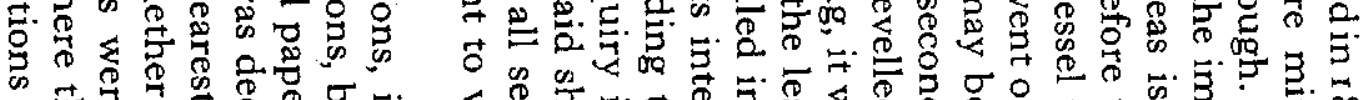

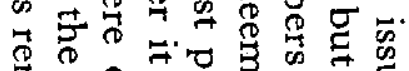

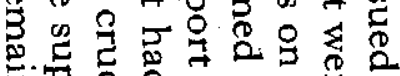

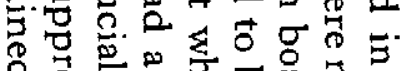
¿. 5.

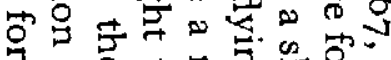

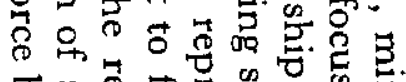

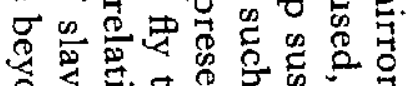

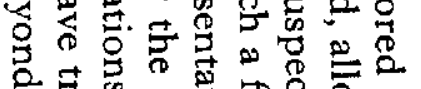

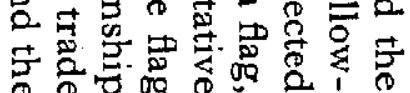

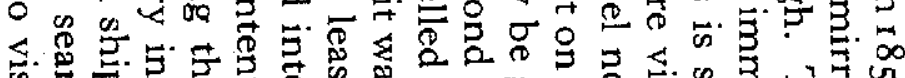

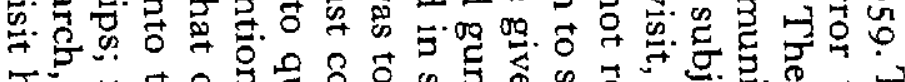

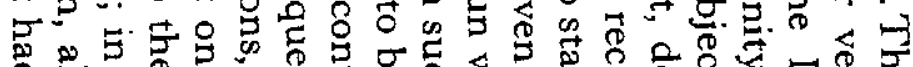

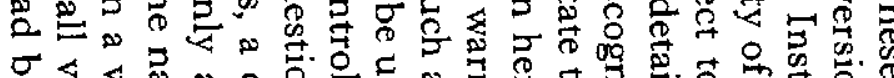

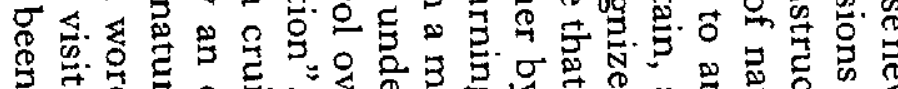

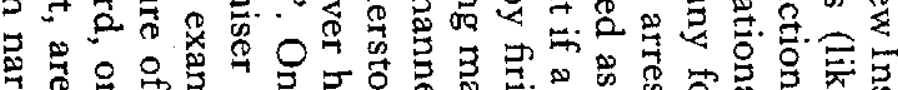

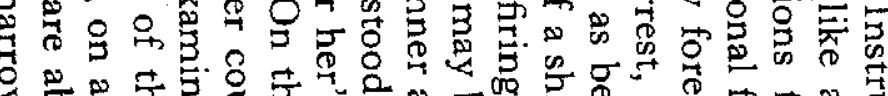

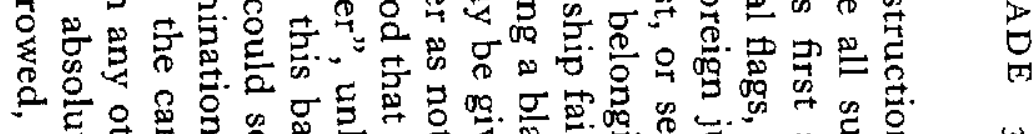

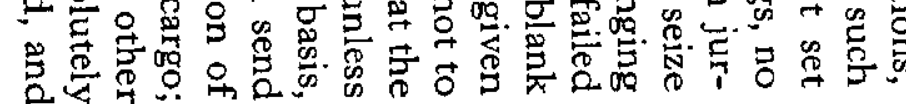




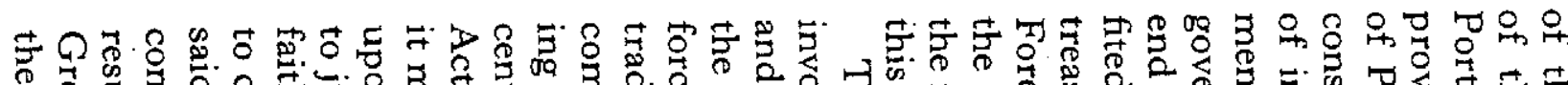

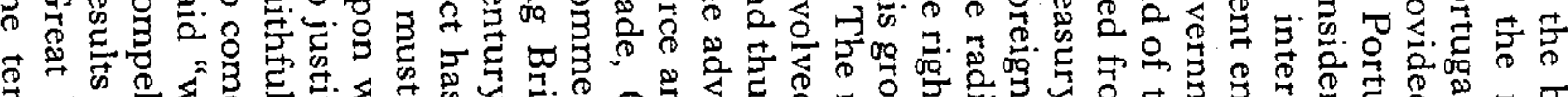

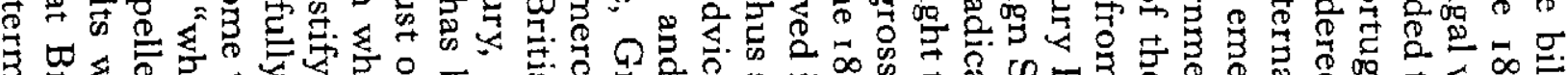

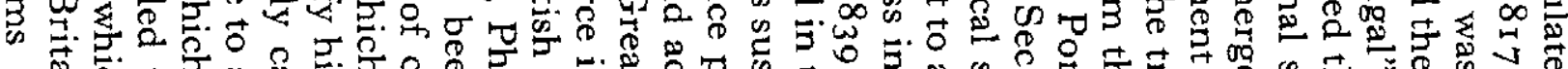

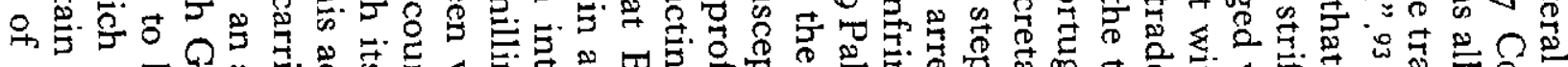

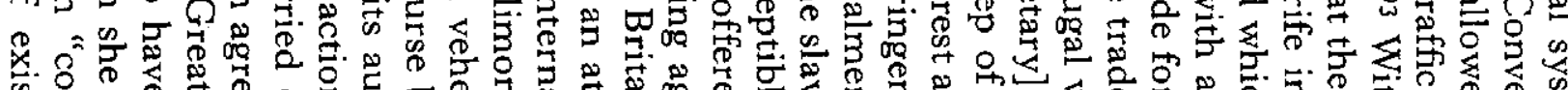

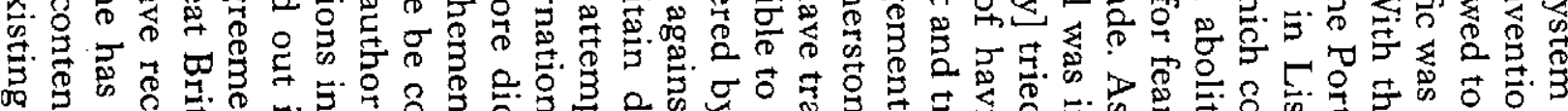

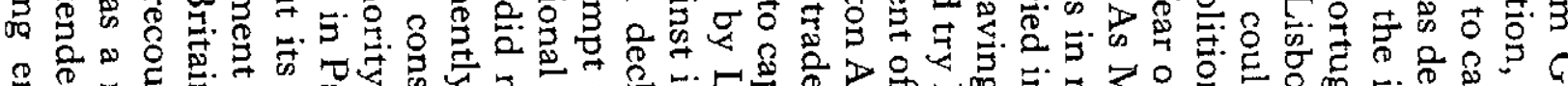

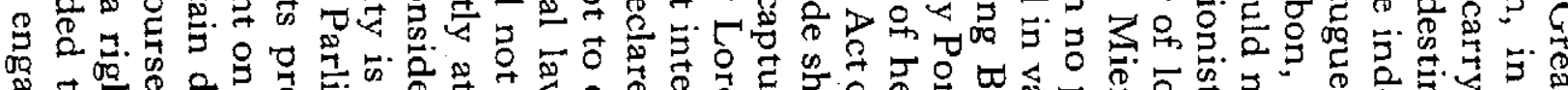

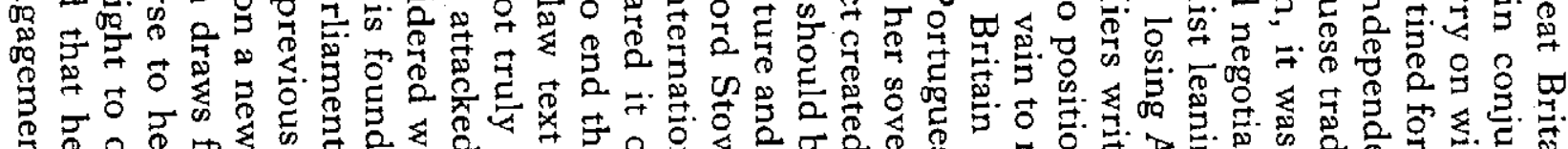
웅

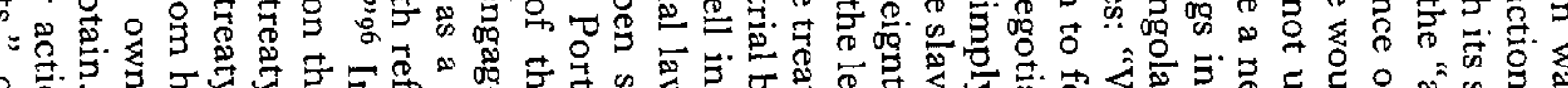

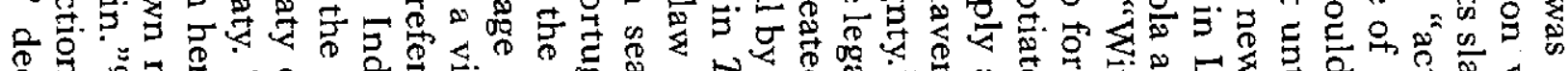

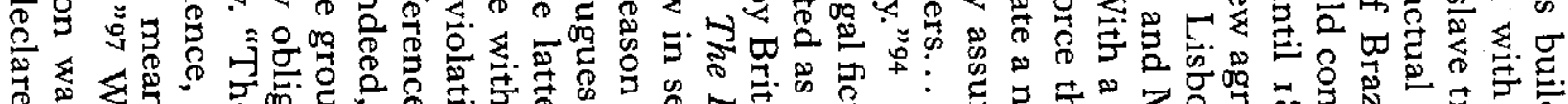

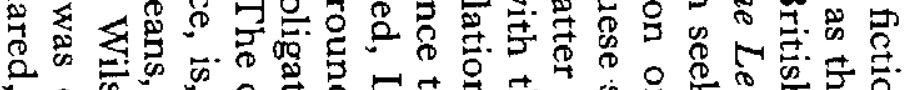

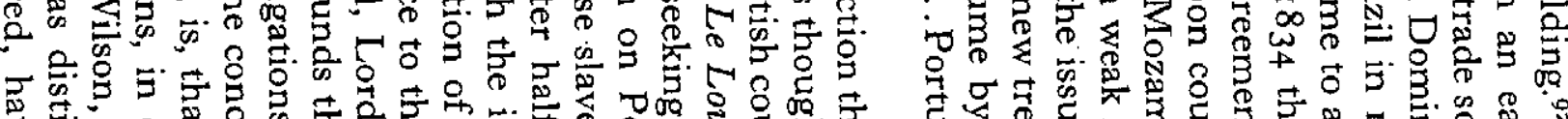

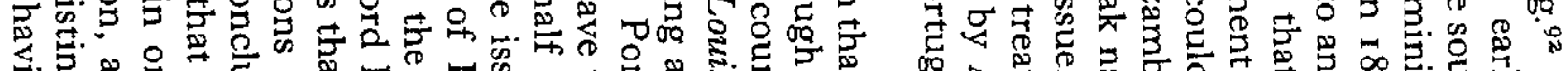

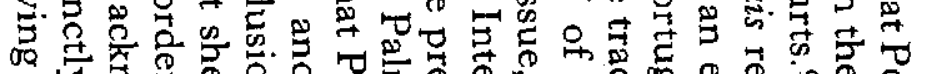

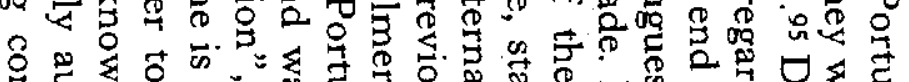

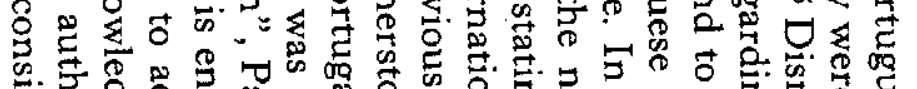

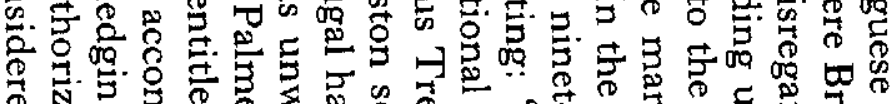

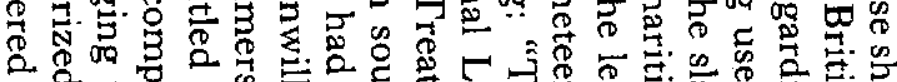

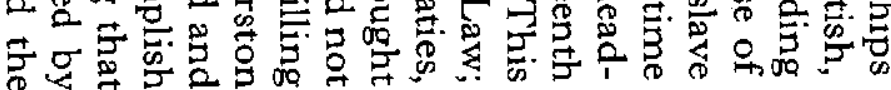

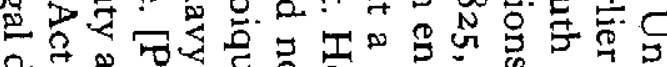

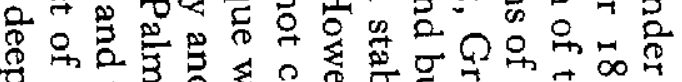

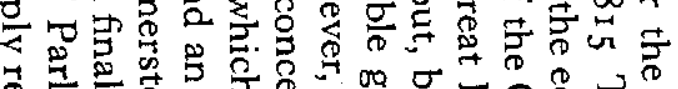

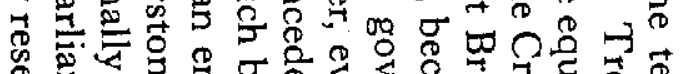

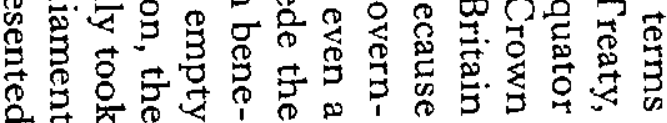

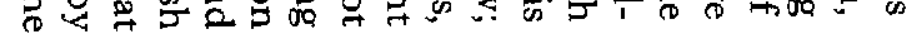




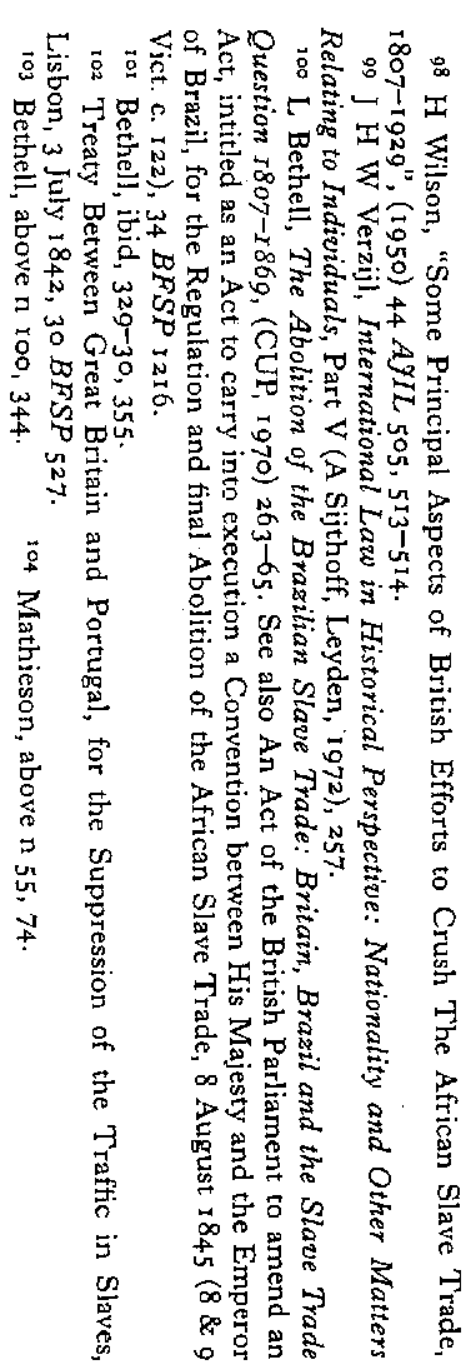

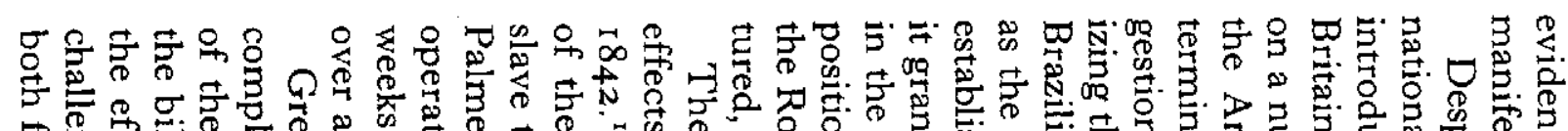

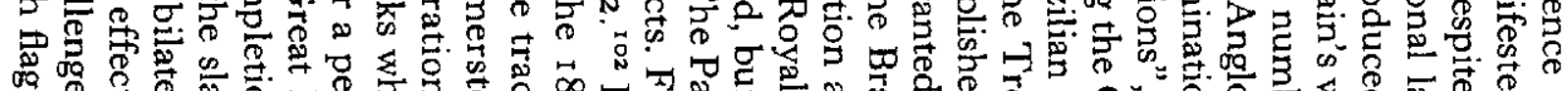

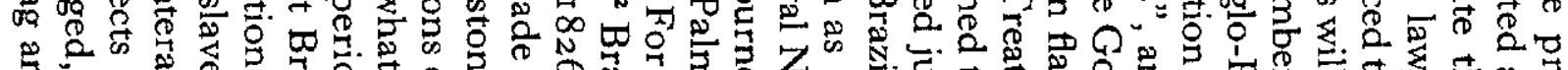

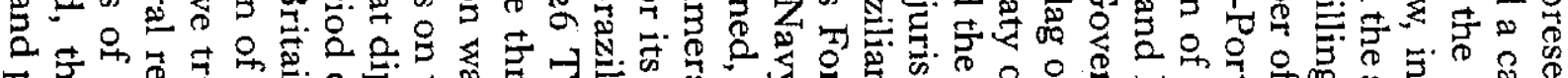

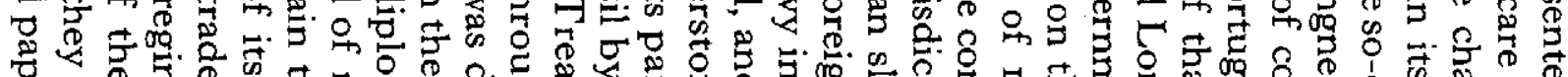

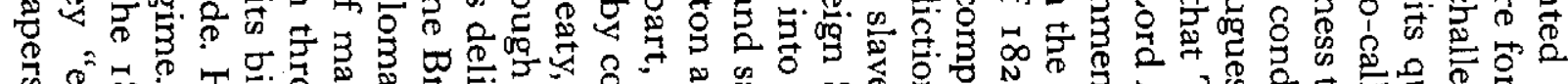

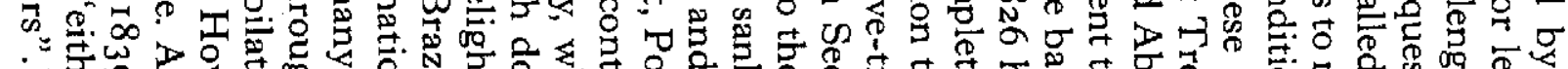

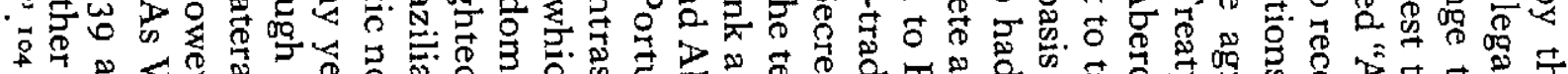

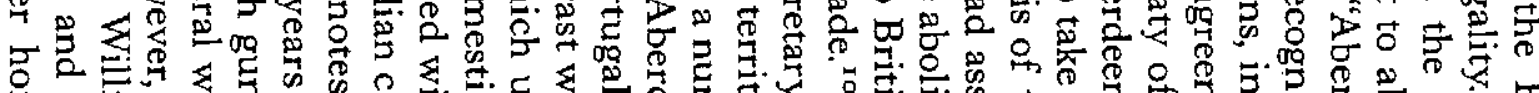

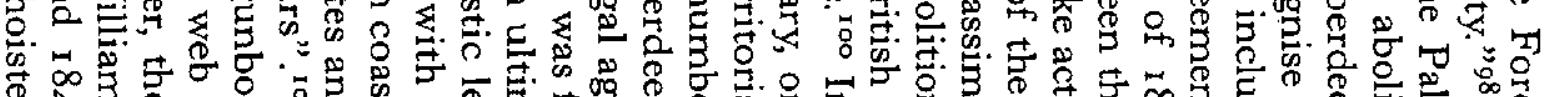

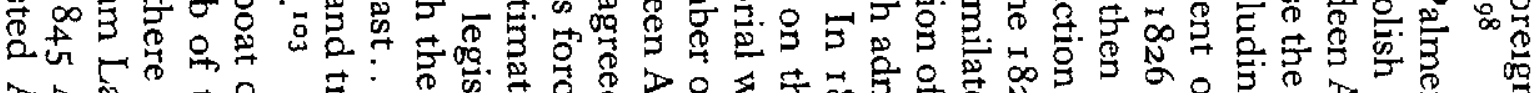

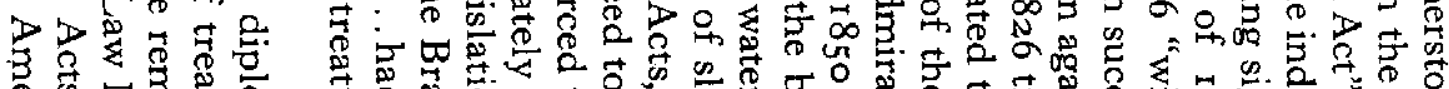

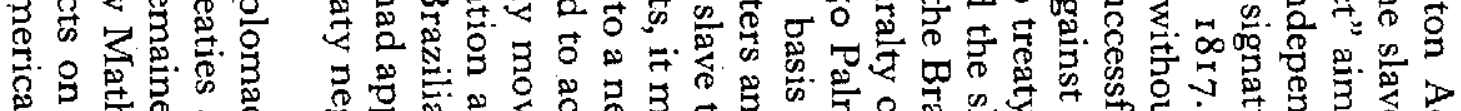

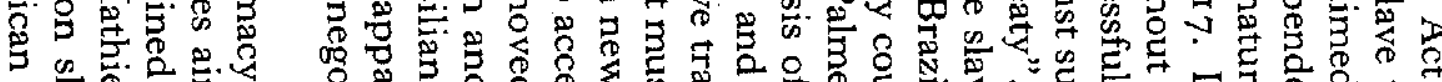

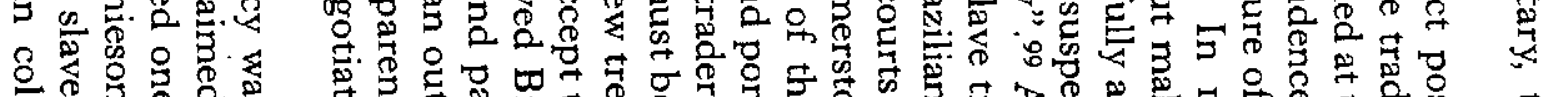

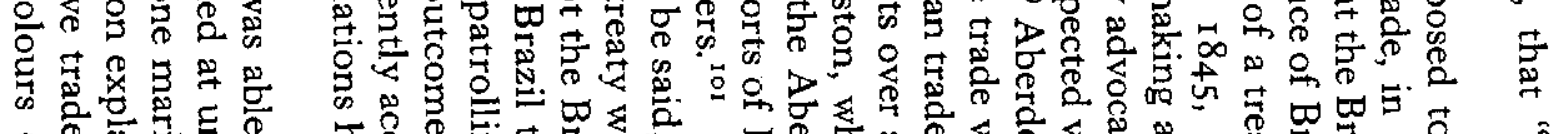

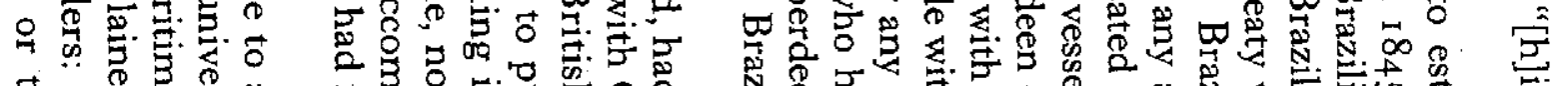
声飞串票 ह

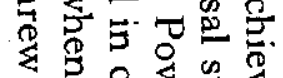

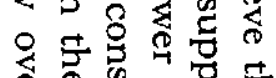

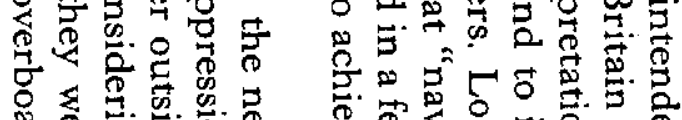

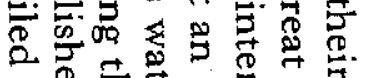

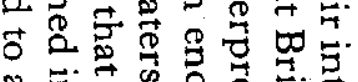

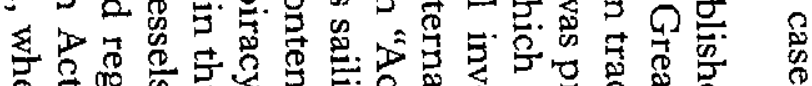

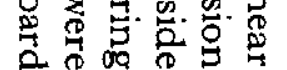

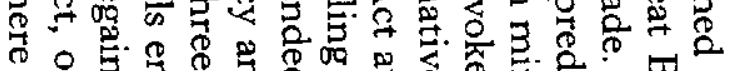

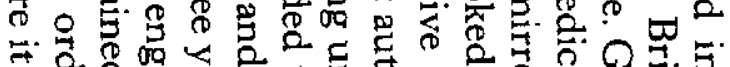



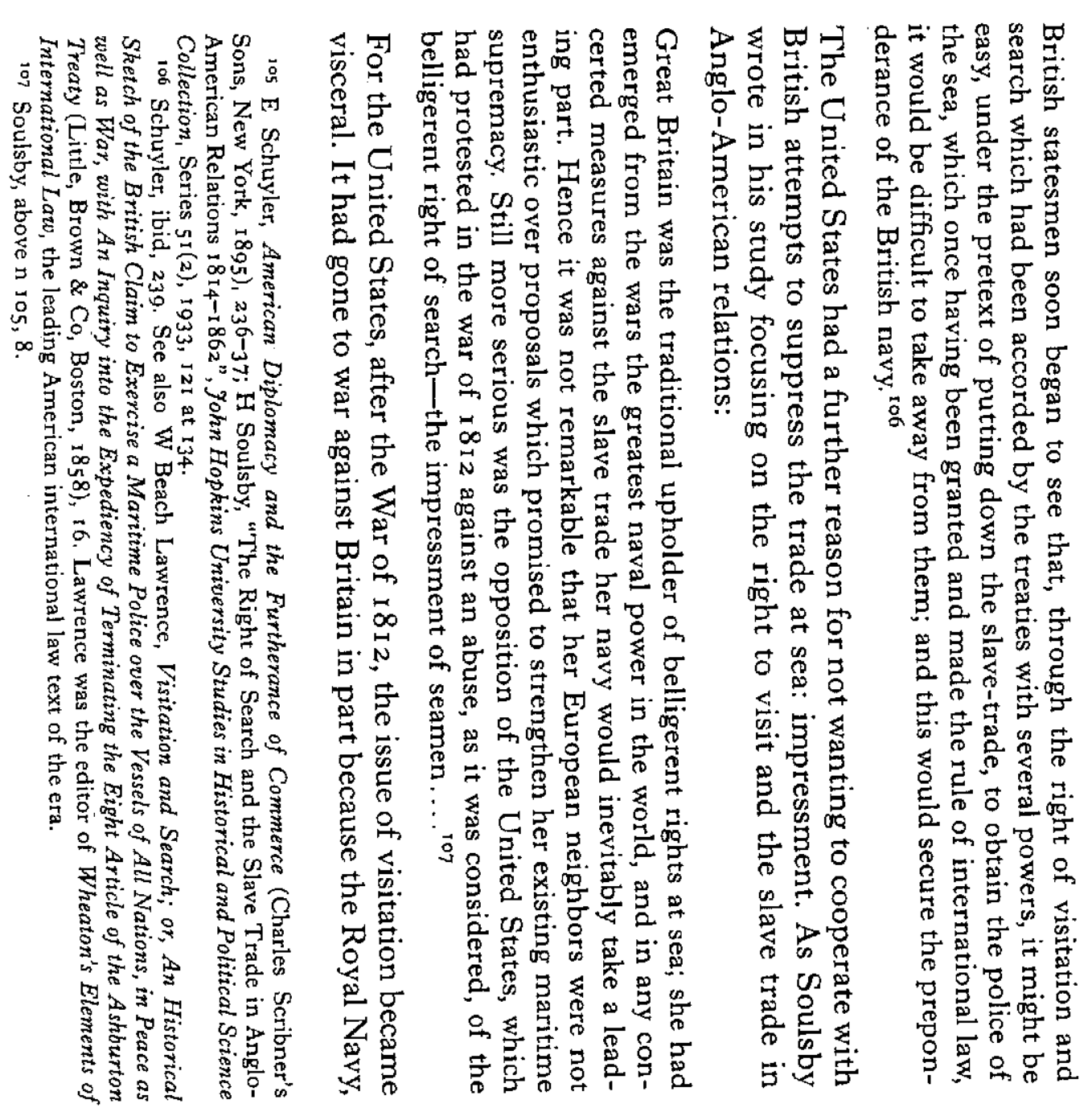

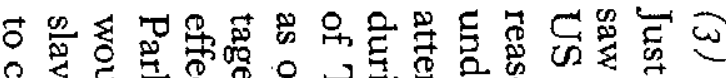

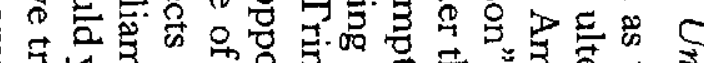

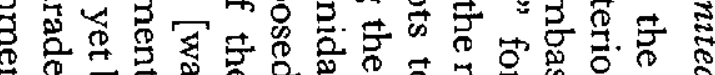

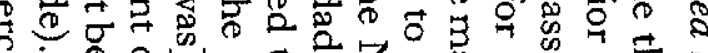
\%

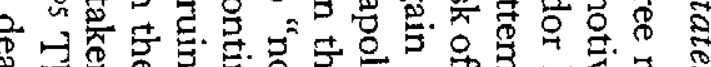

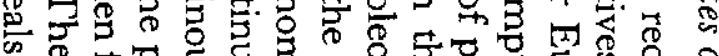

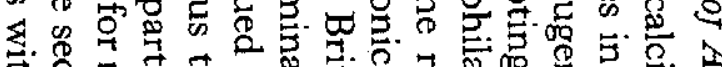

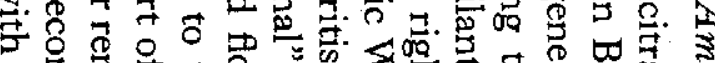

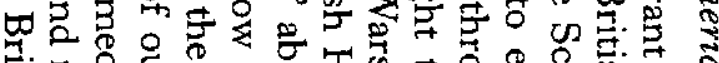

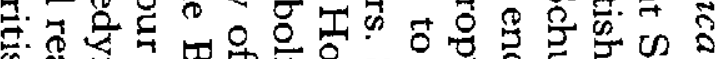

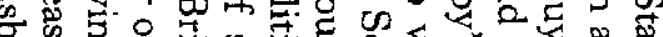

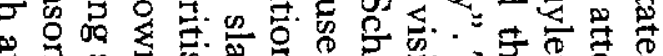

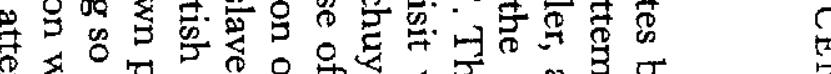

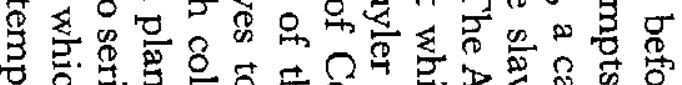
क

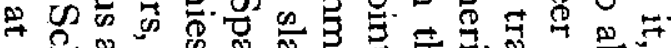

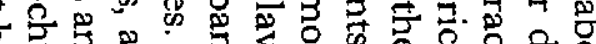

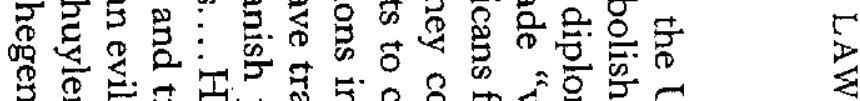

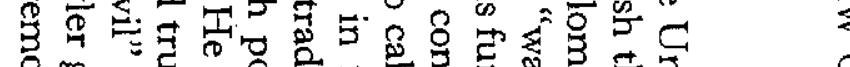

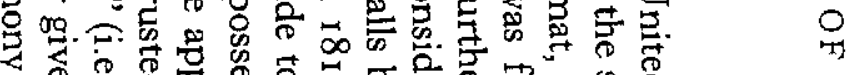

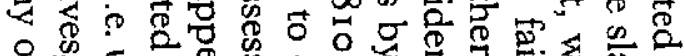

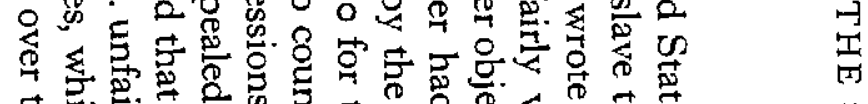

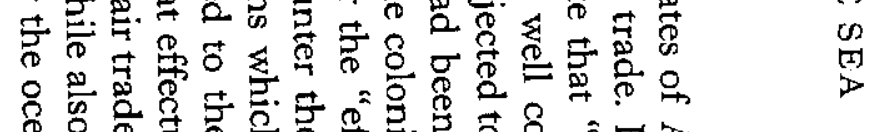

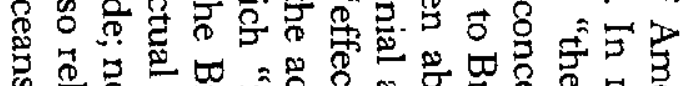

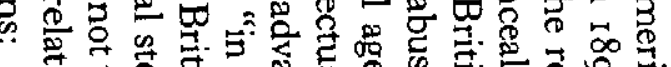

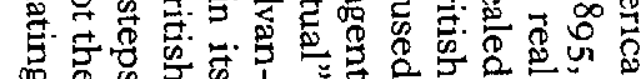
年 

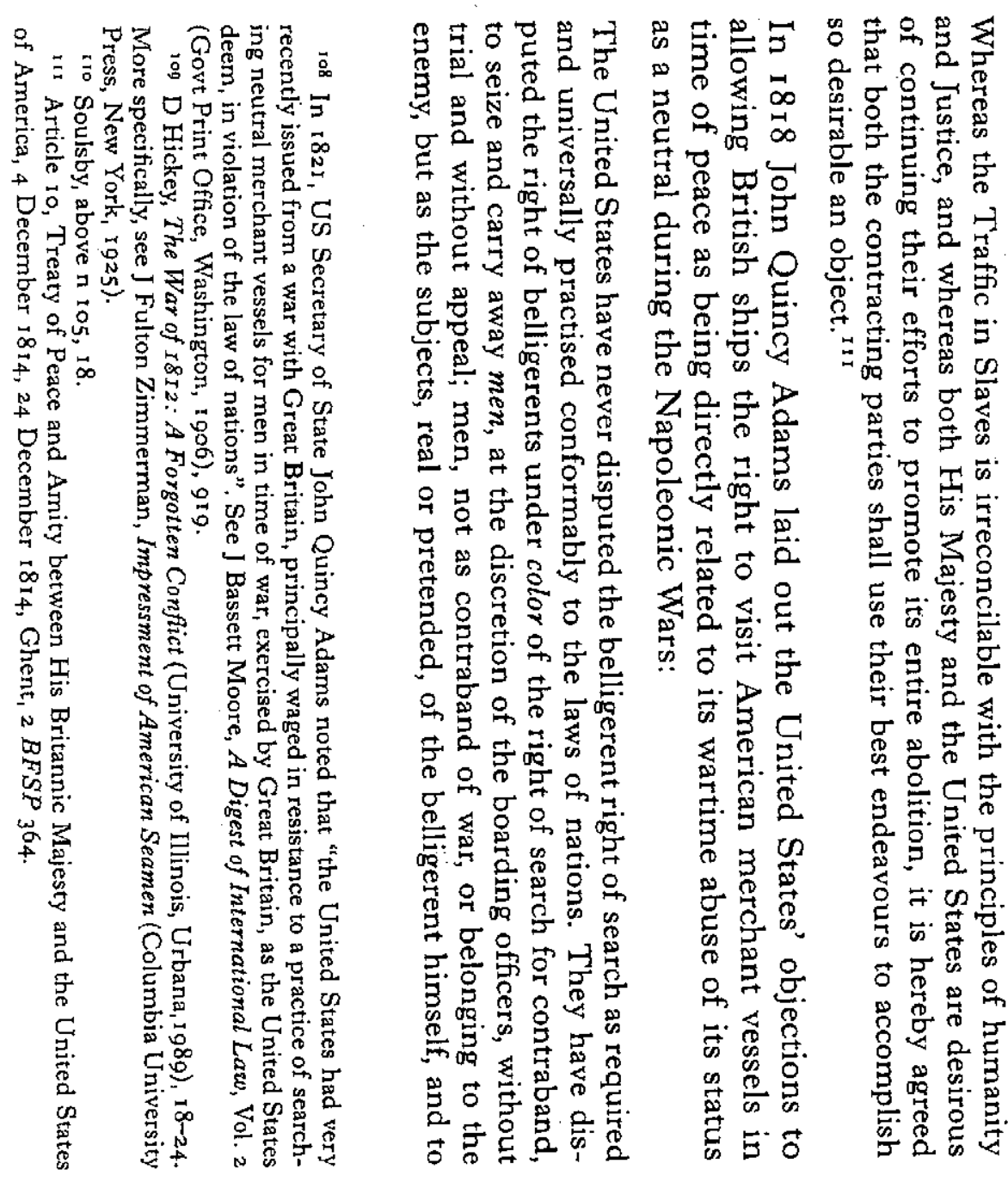

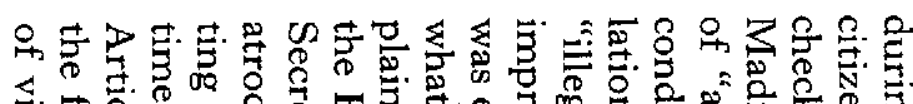

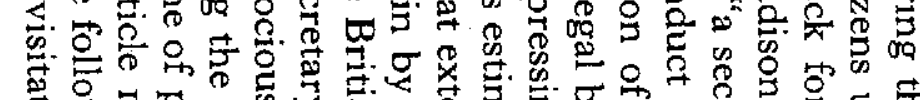

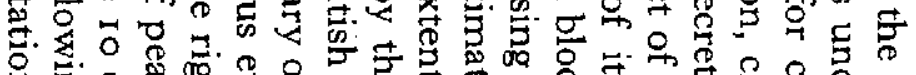

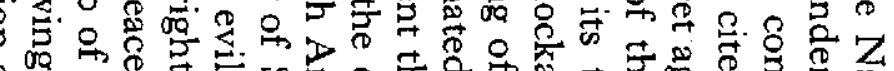

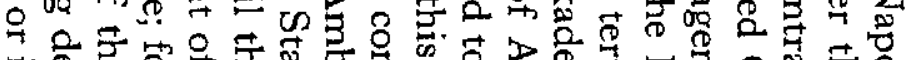

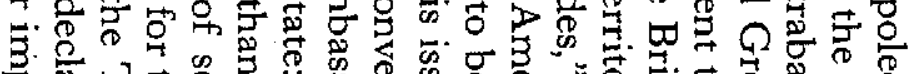

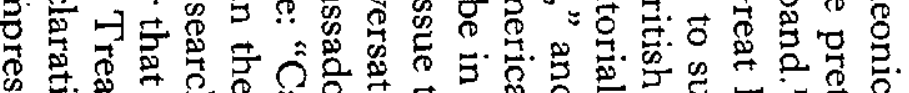

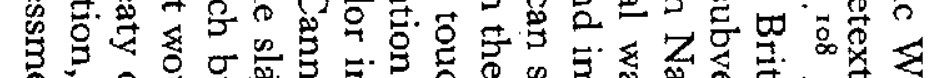

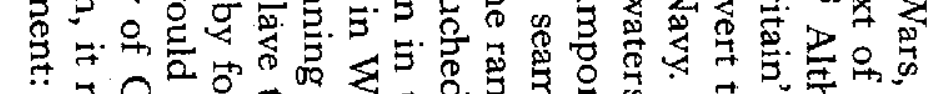

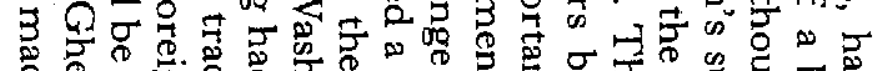
है

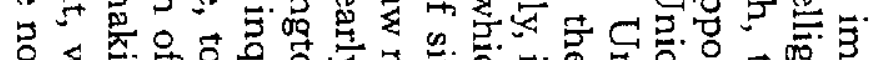

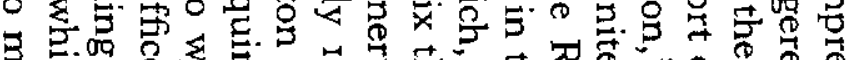

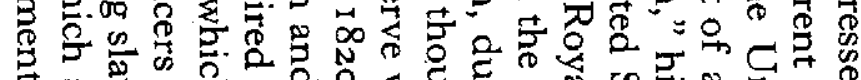
. 胥象

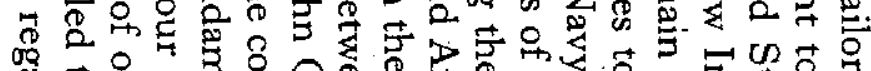

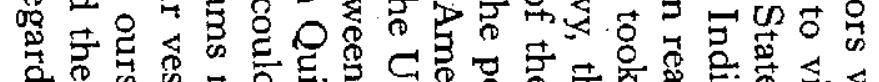

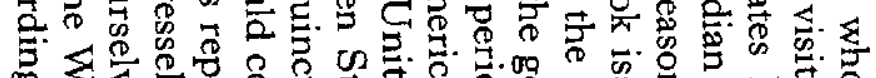

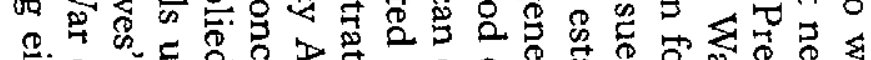

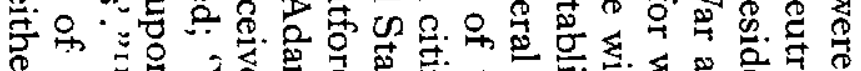

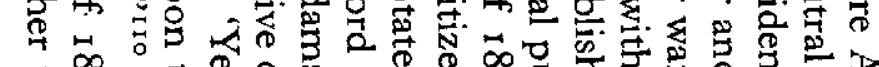

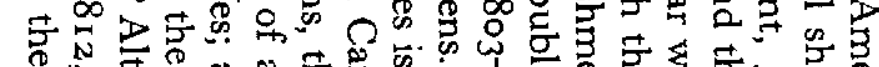
क 


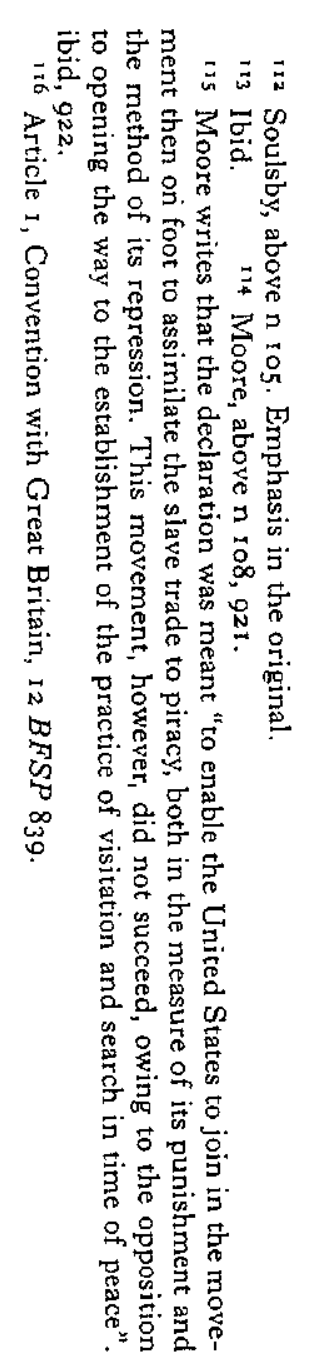

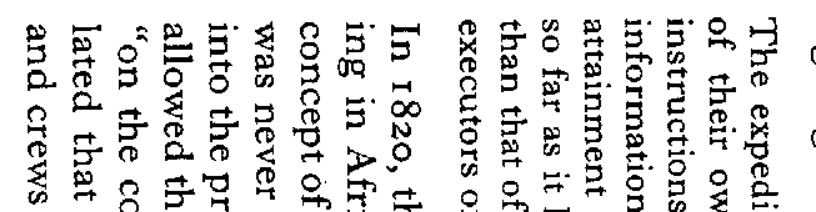

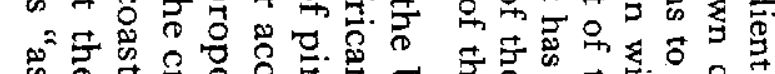

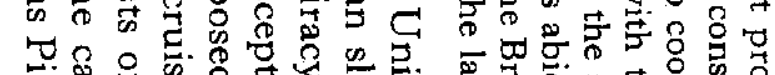

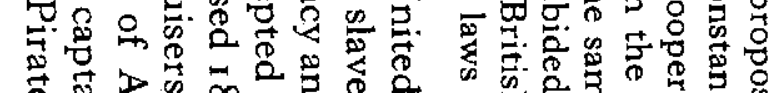

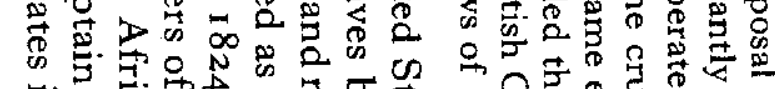

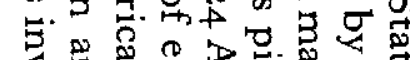

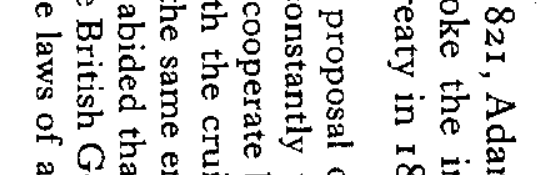

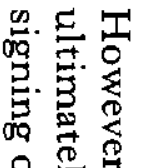

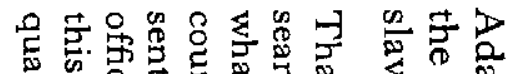

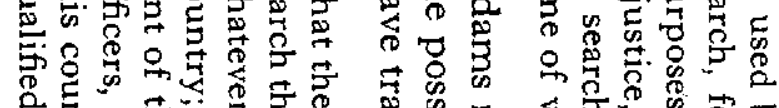

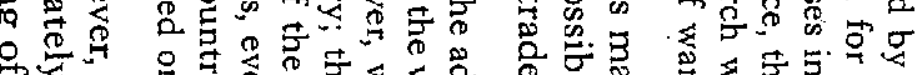

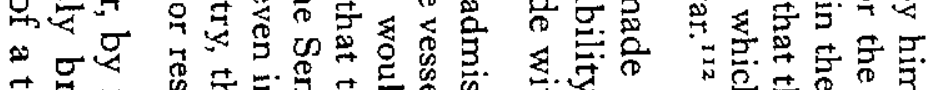

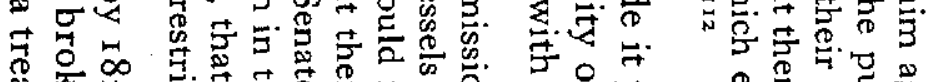

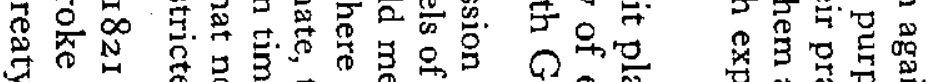

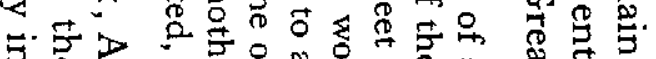

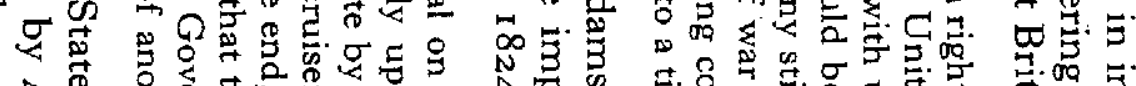

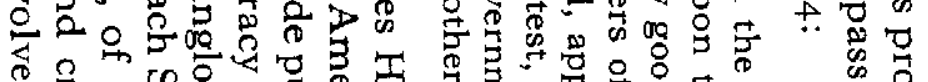

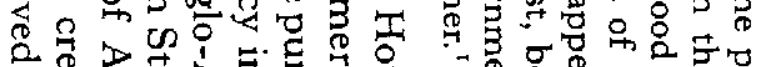

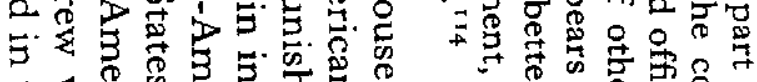

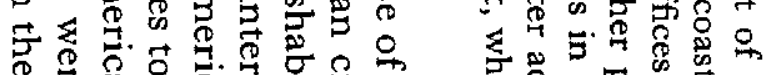

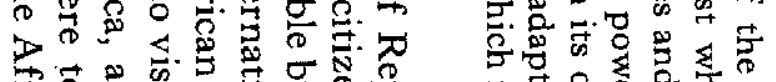

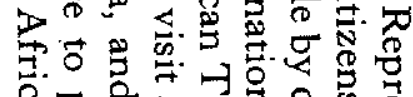

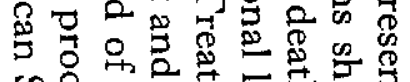

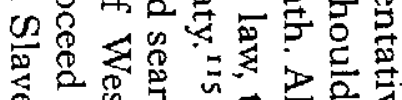

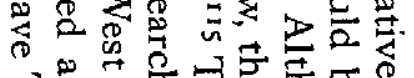

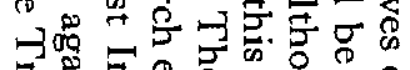

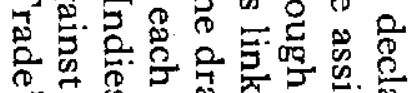
$=\begin{gathered}0 \\ 0\end{gathered}$

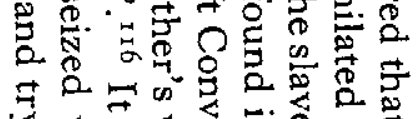

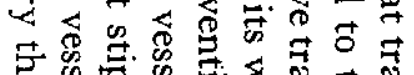

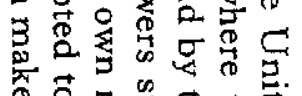

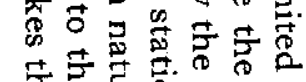

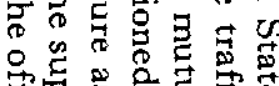

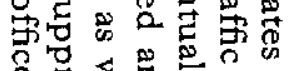

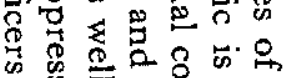

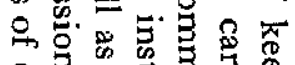

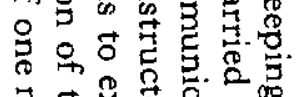

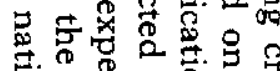

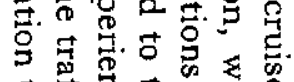
के क 0 क 原它

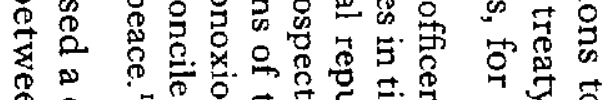

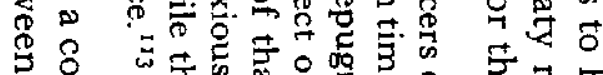

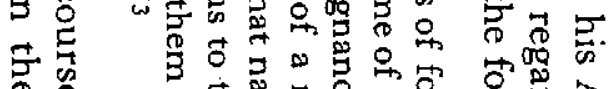
क

芝 0

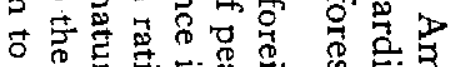

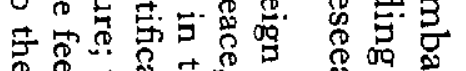

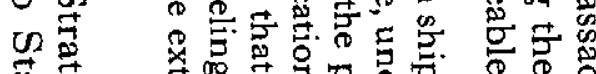

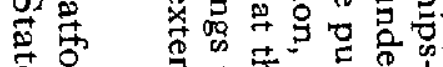

要点

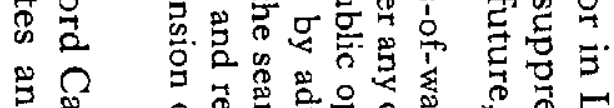
路

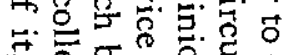

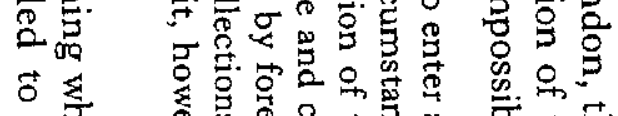

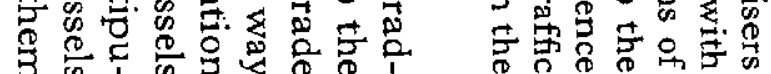

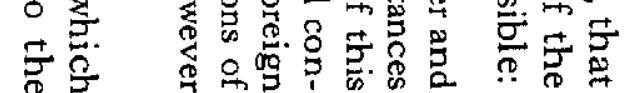

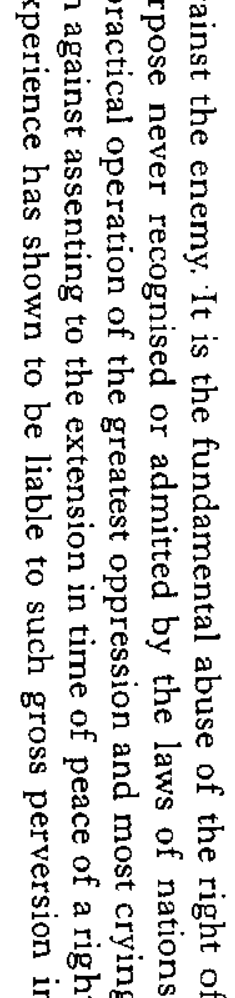




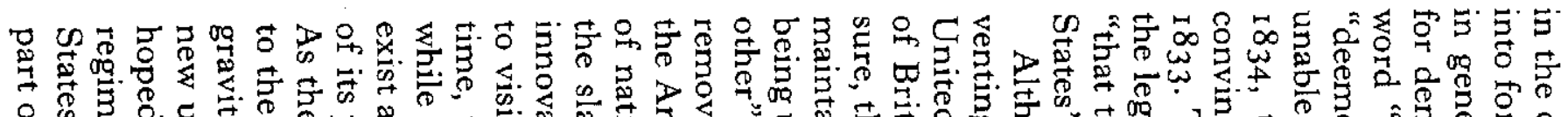

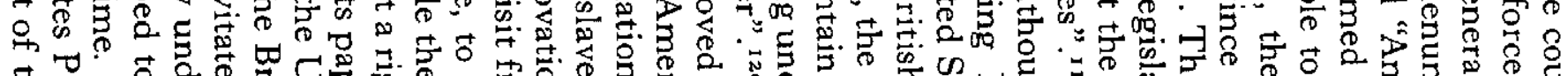

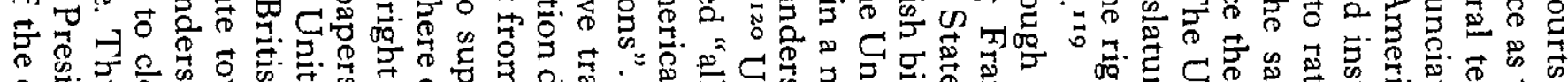

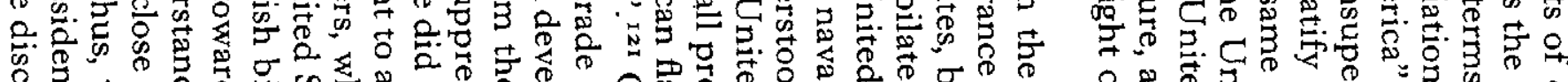

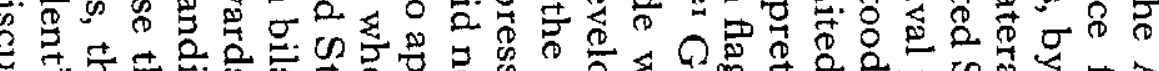

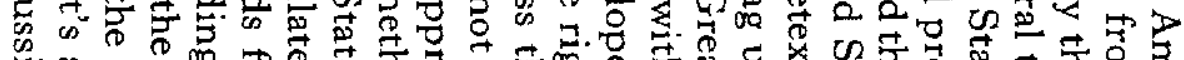

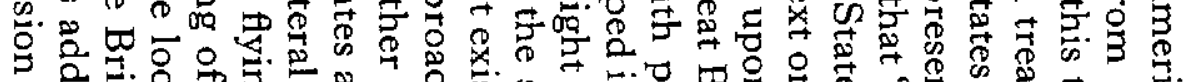

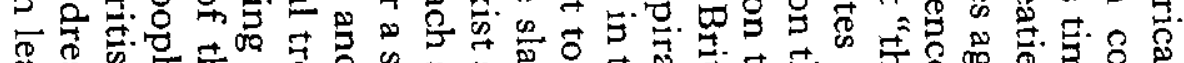

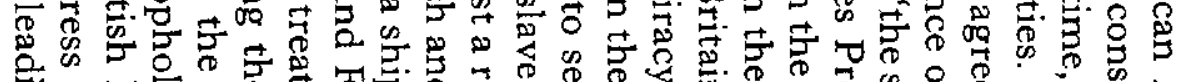

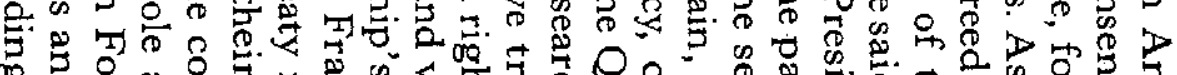

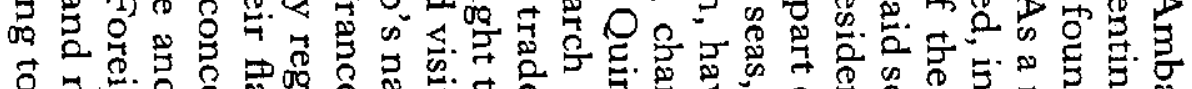

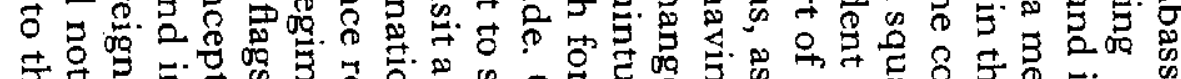

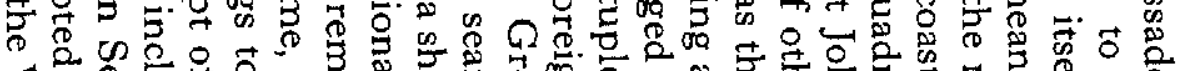

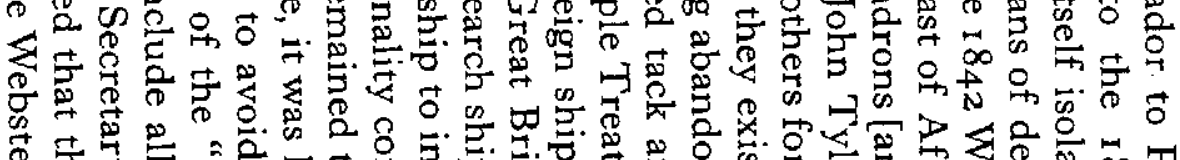

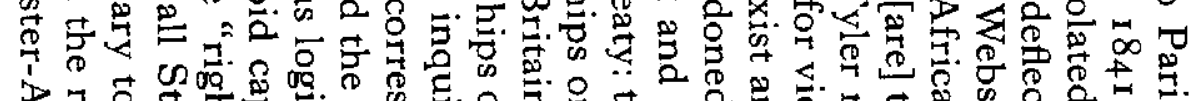

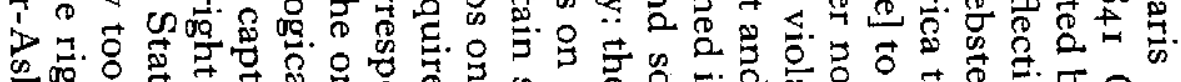

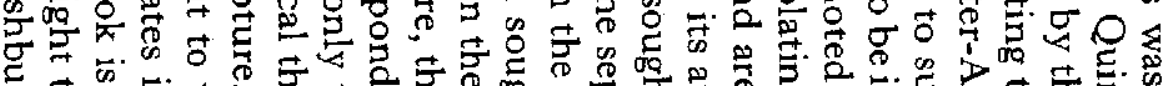

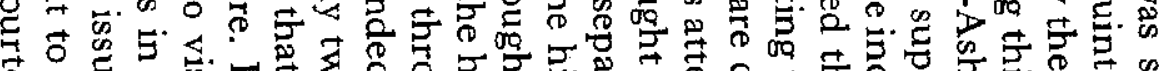

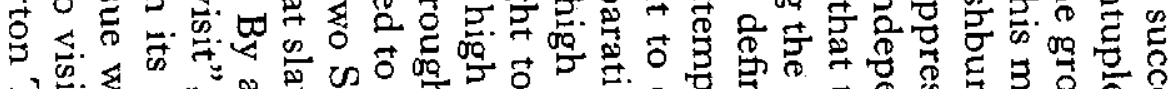

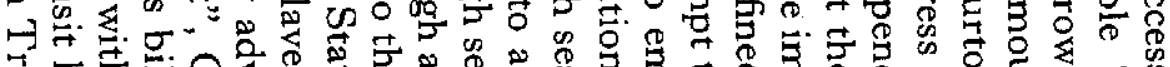

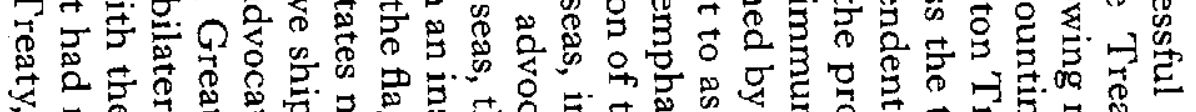

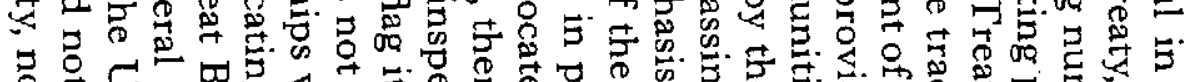

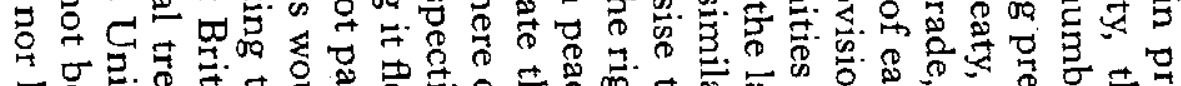

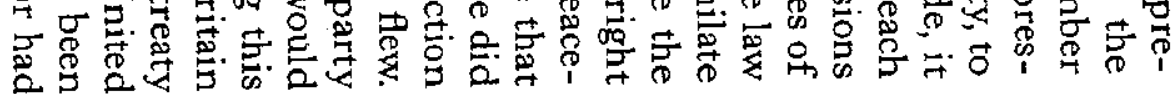

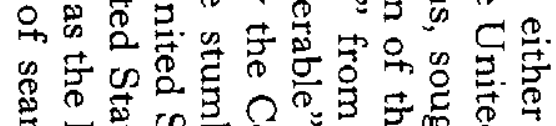

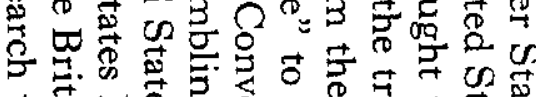

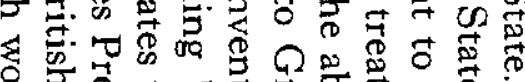

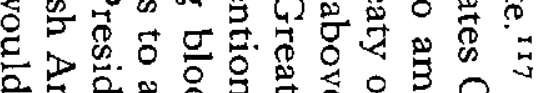

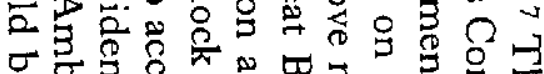

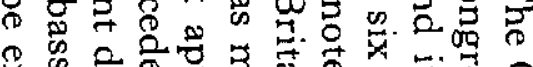

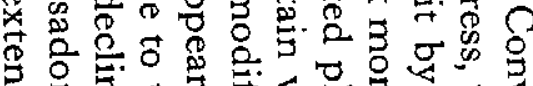

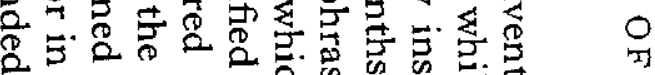

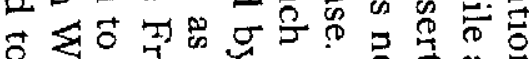

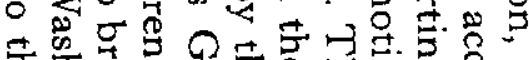

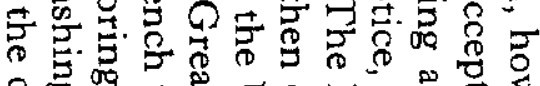

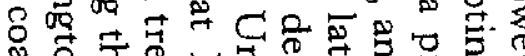

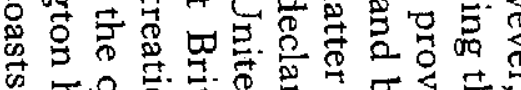
के

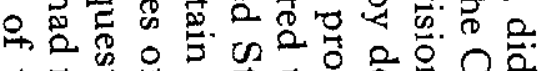

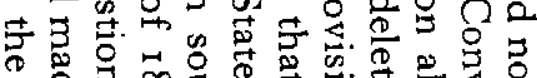

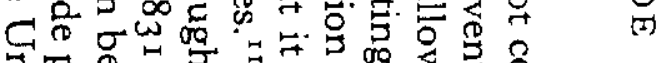

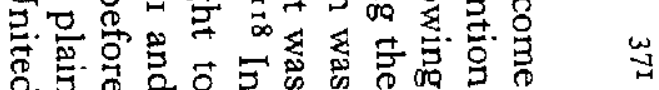


¿ \た心

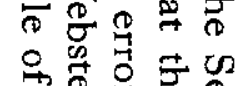

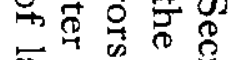

\& 5 का

₹

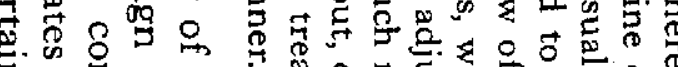

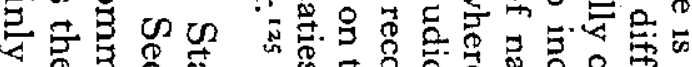

का

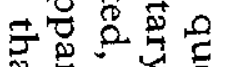

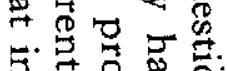

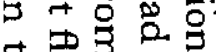

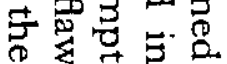

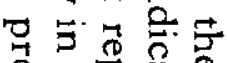

Tे क

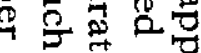

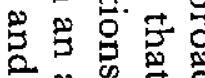

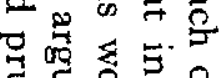

들

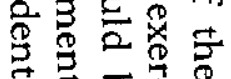

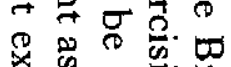

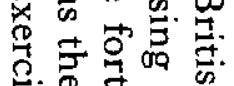

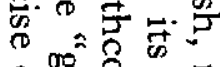

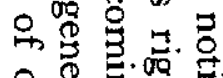

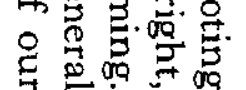

原哭

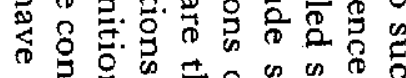

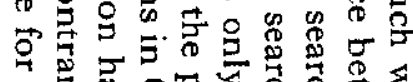

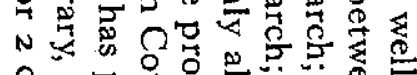

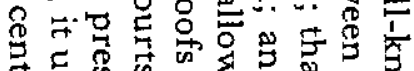

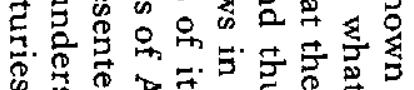

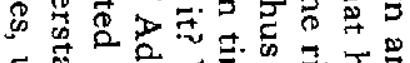

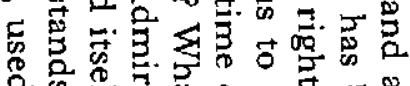

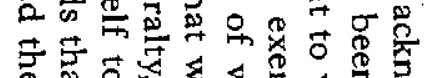

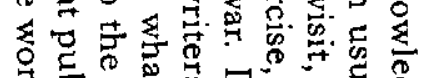

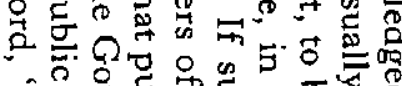
4.

布局

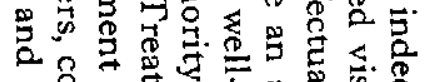

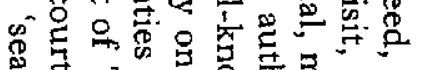

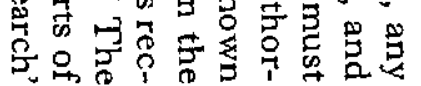

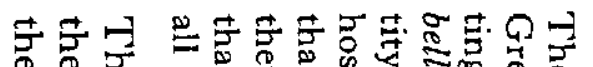

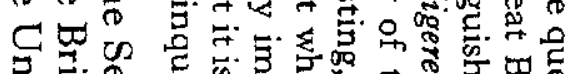
․․:

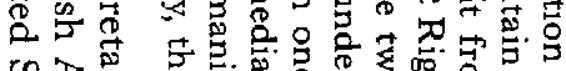

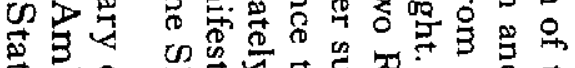
尊煰

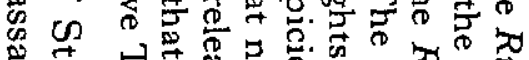

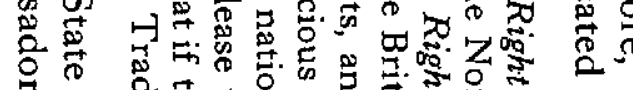
․

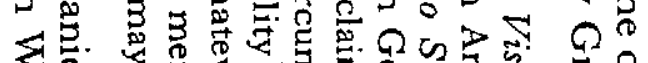
क्ष

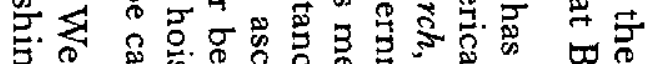
每

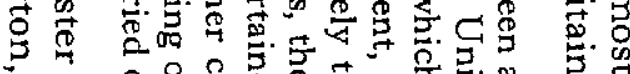

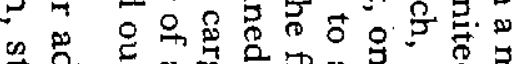

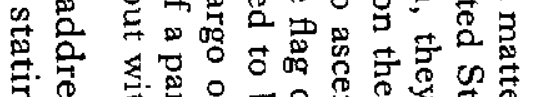

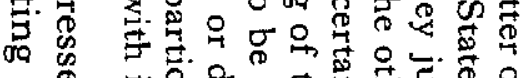

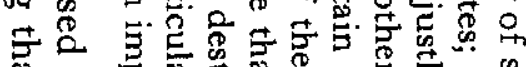

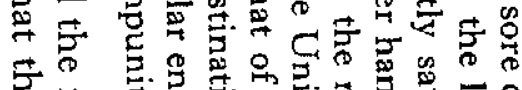

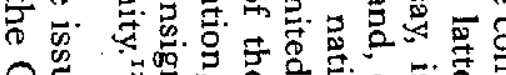

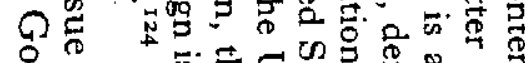

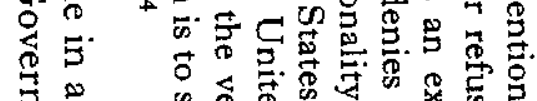

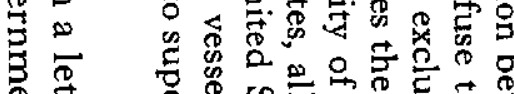

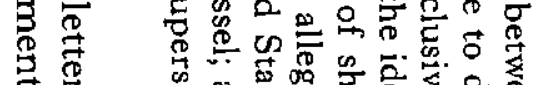

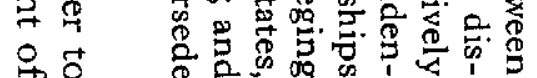

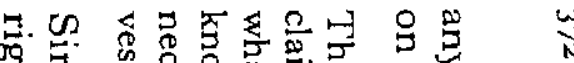

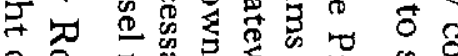

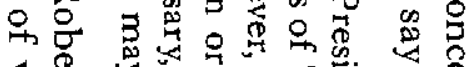

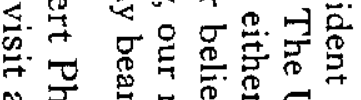

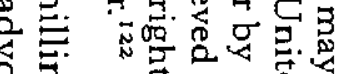

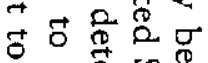

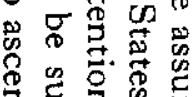

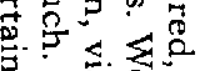
必些

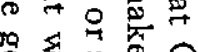
政

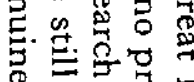
政 密. 只预.

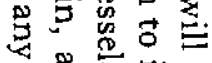

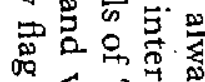

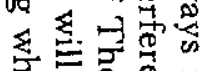

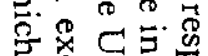

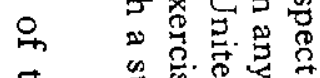
穷

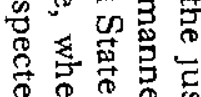

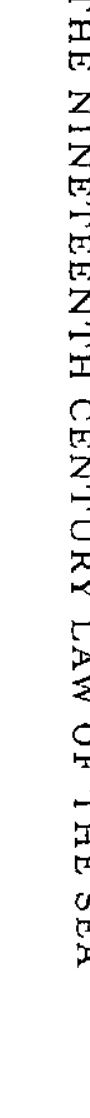




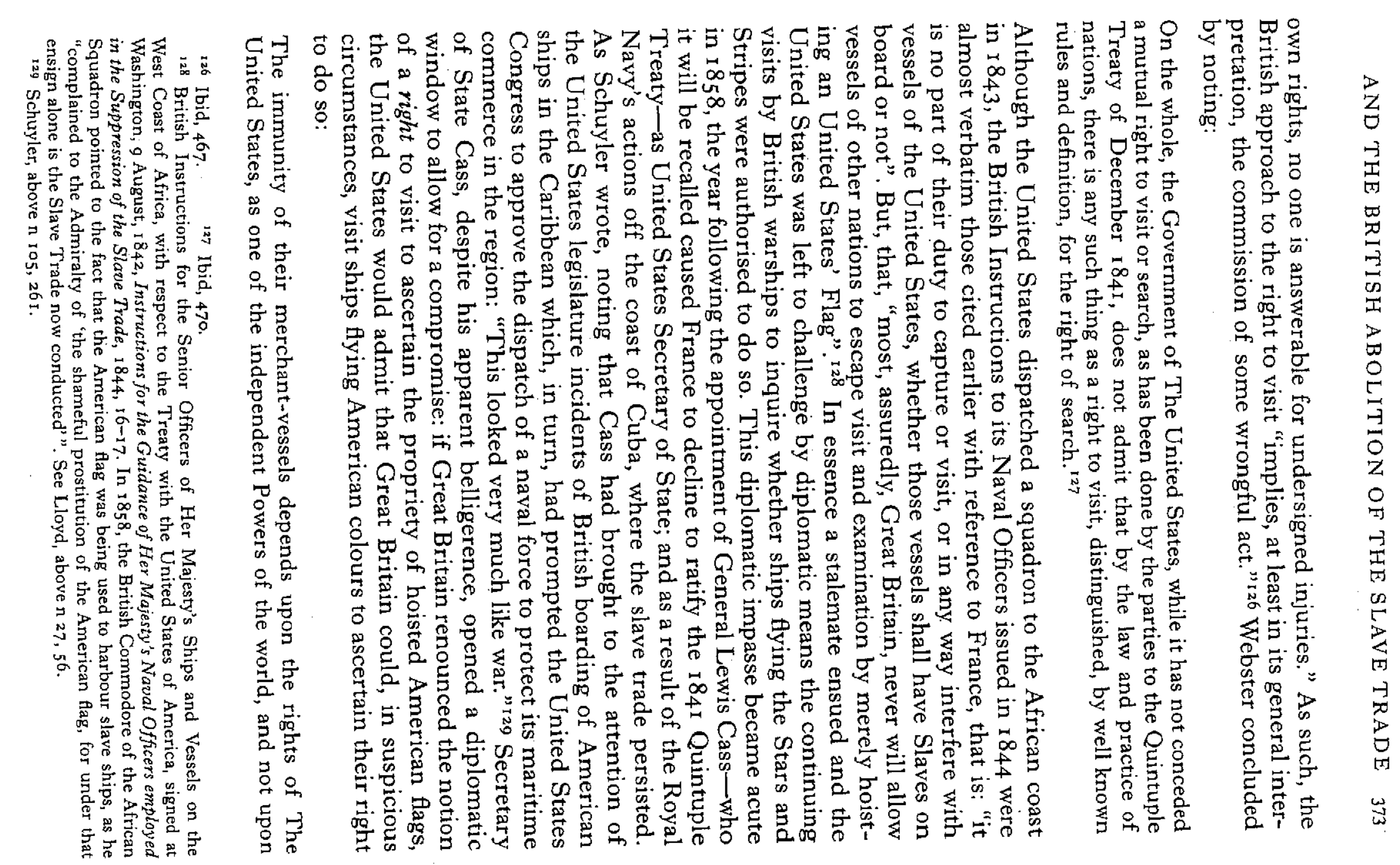




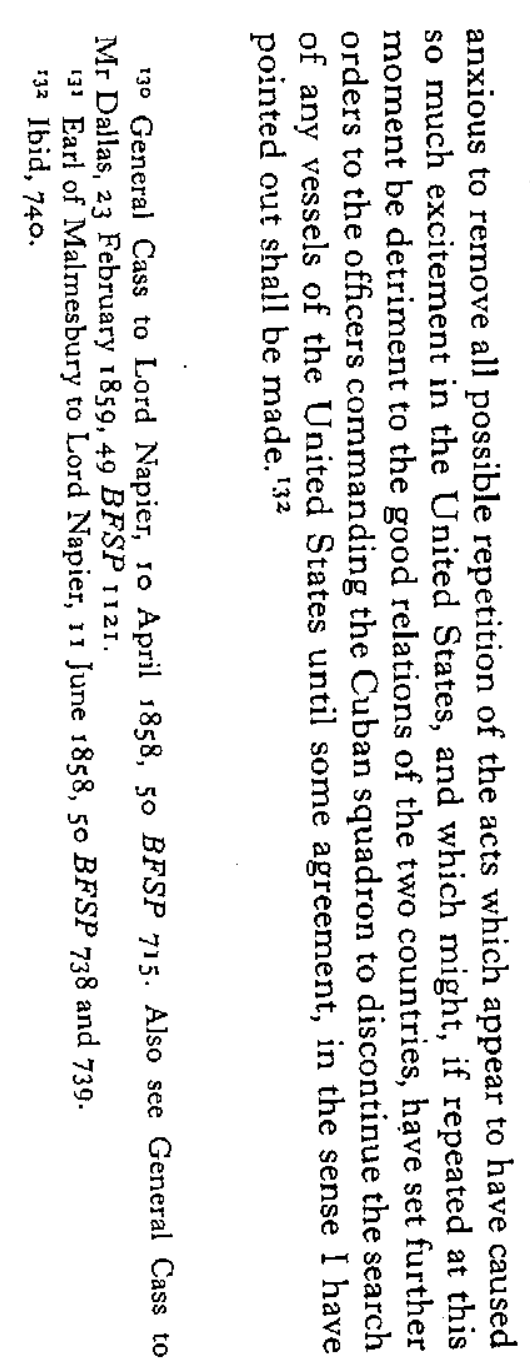

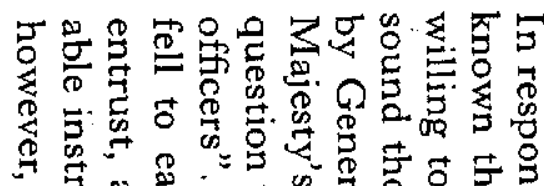

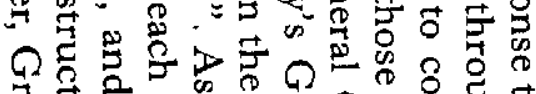

Q

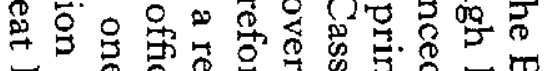
菏束

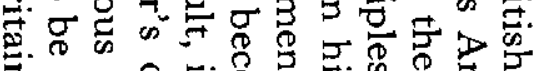

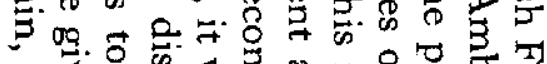

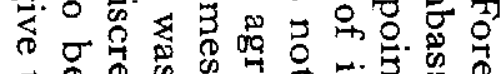

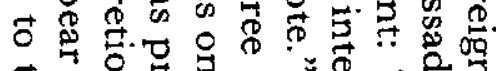
둥요영

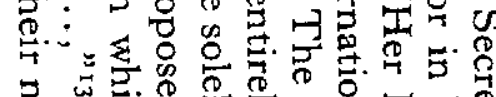

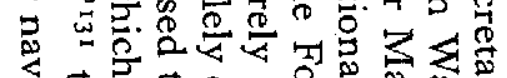

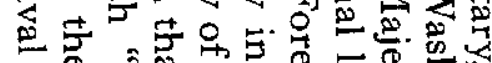

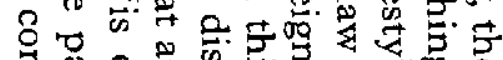
3 क 司. क

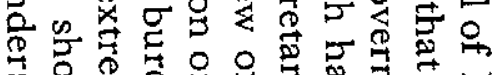

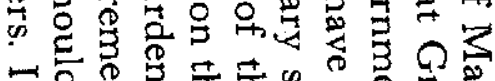

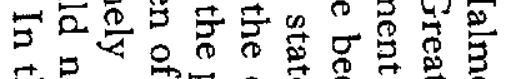

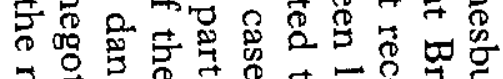

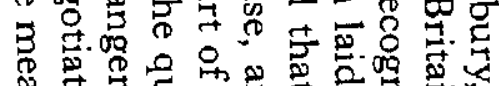

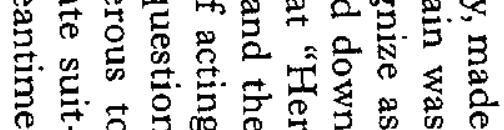
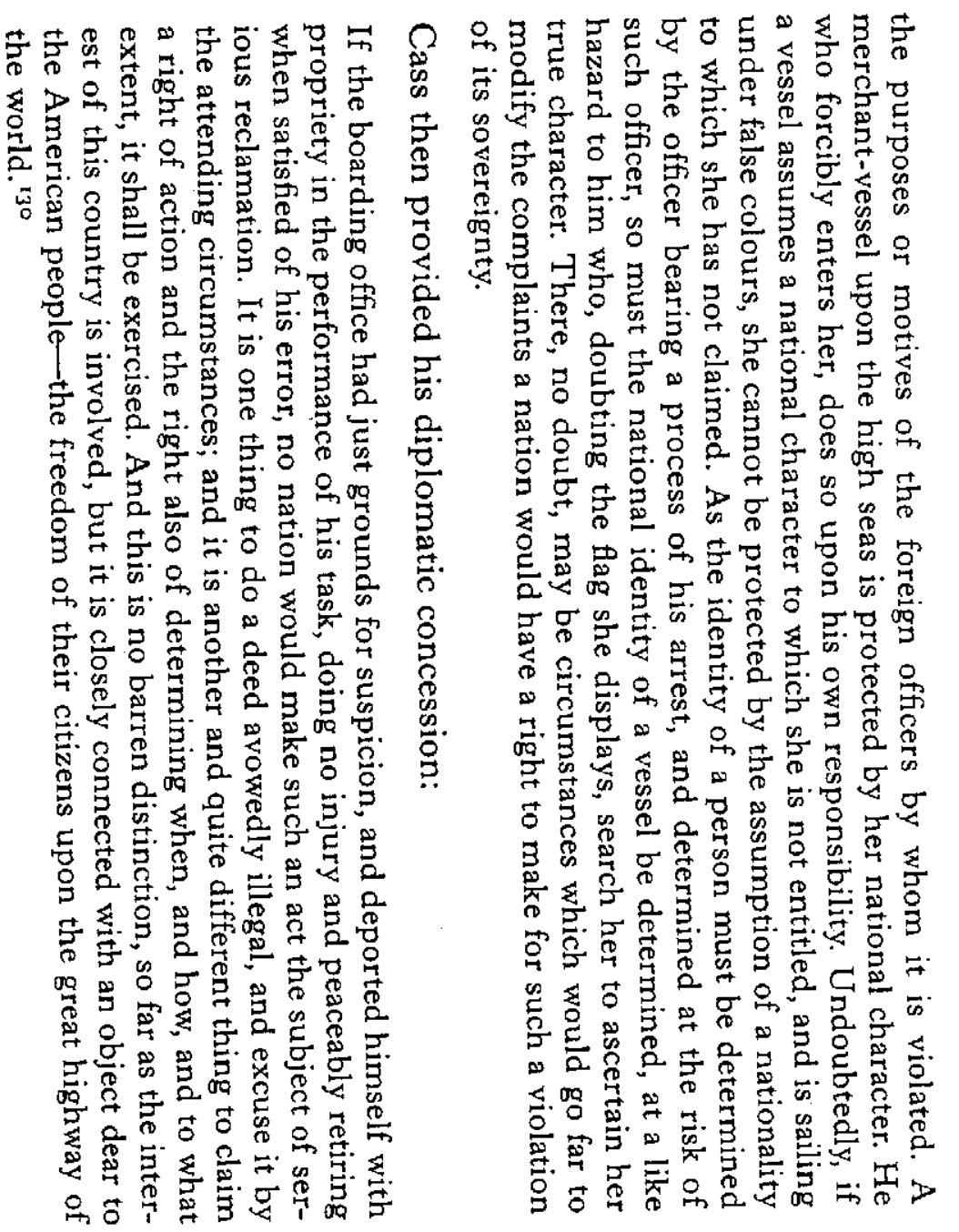

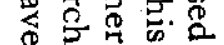




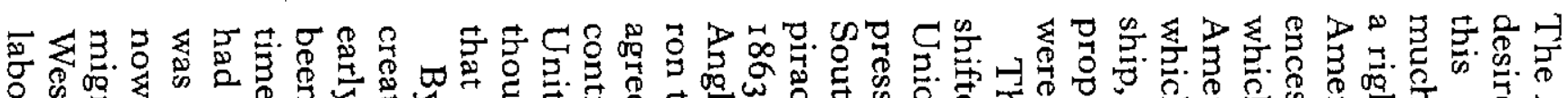

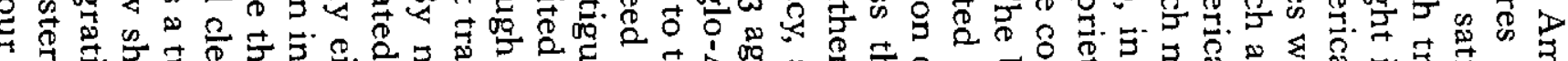

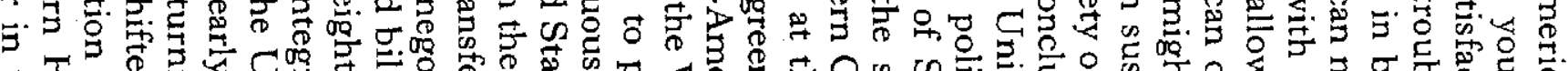

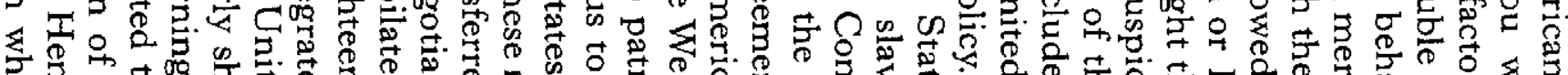

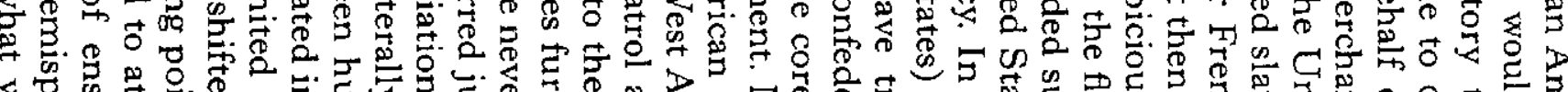

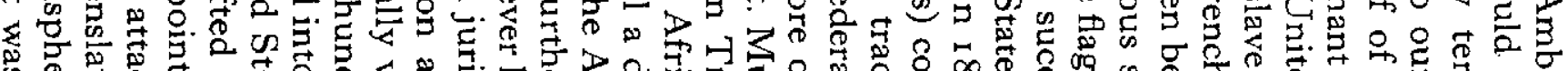

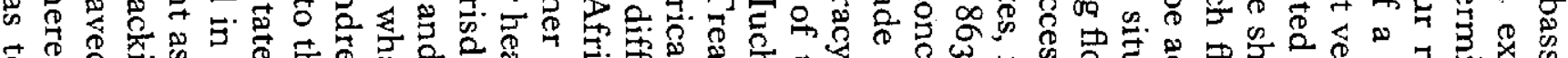

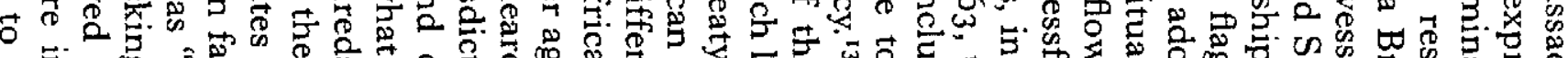

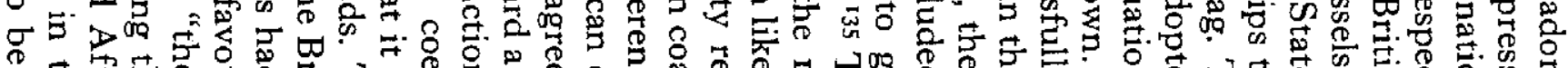

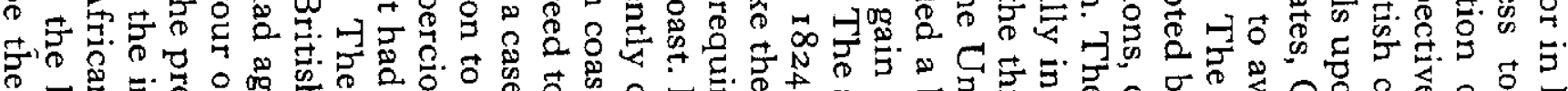

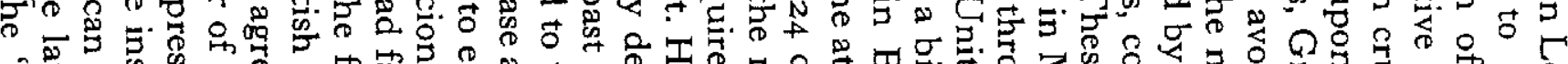

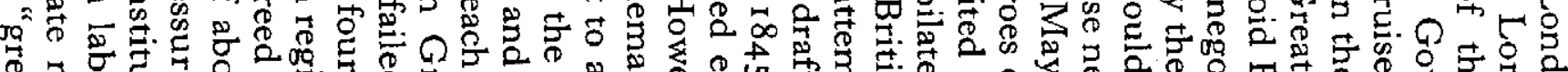
굴.

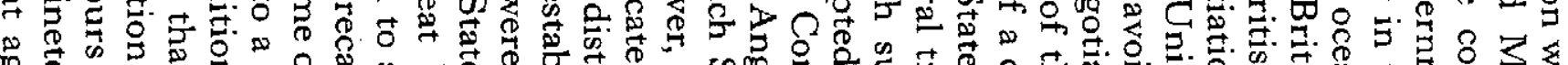

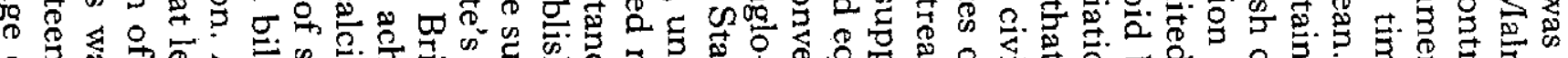

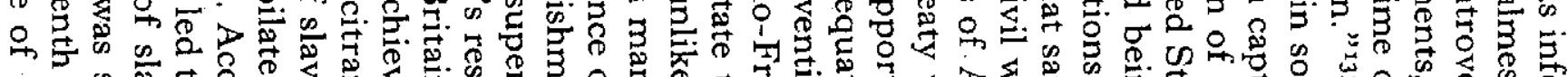
₹.

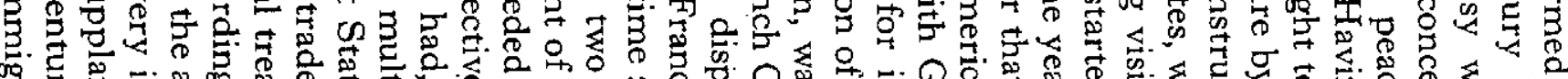

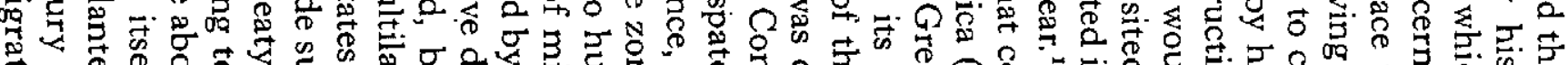

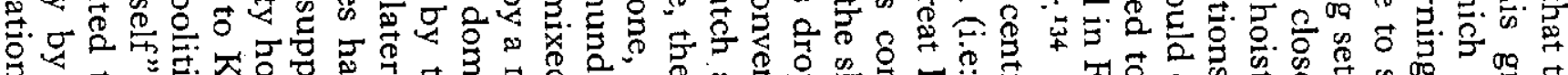

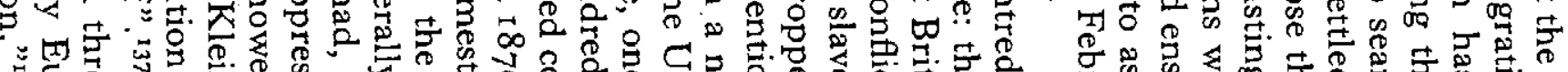

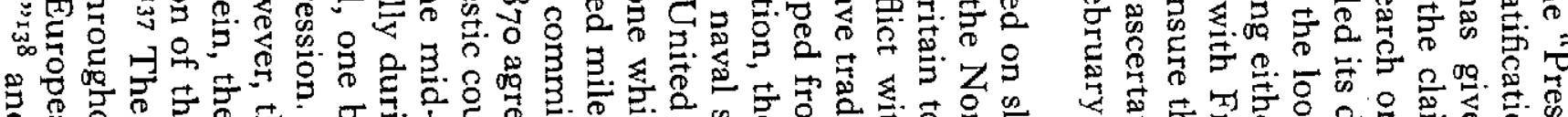

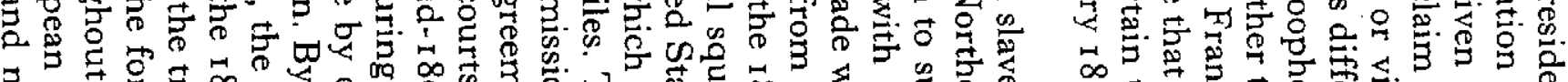

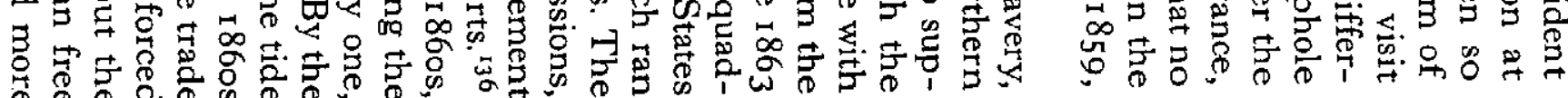




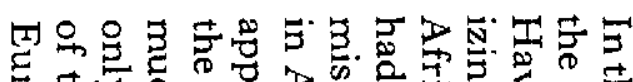

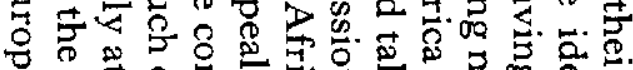

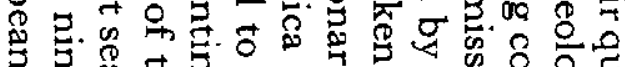

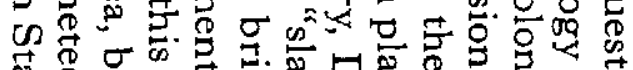

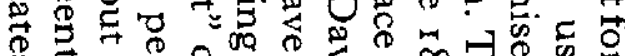
क

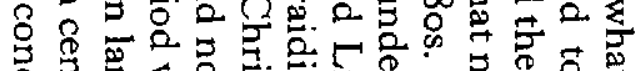

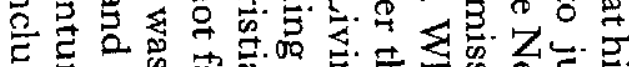

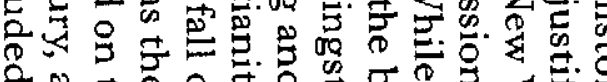

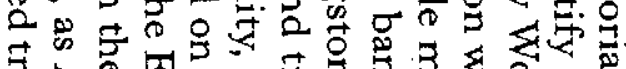

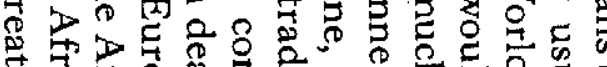

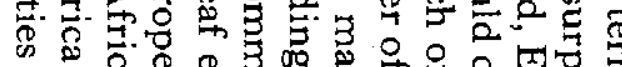

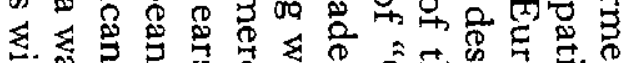

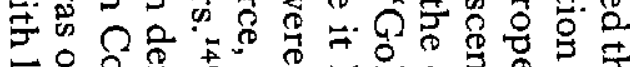
웅

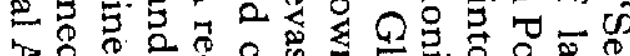

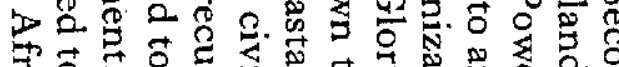

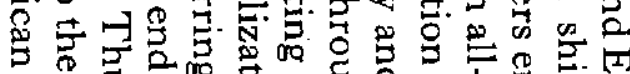
( )

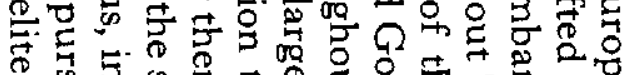

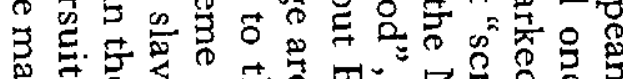

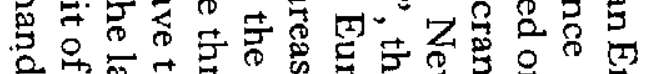

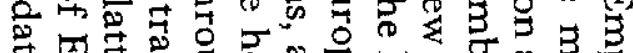

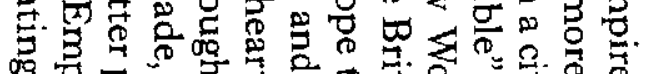

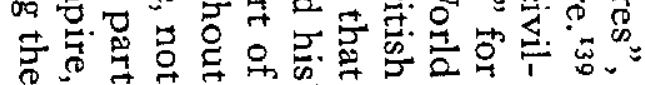

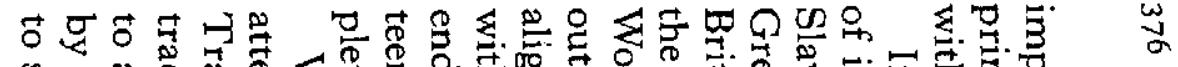

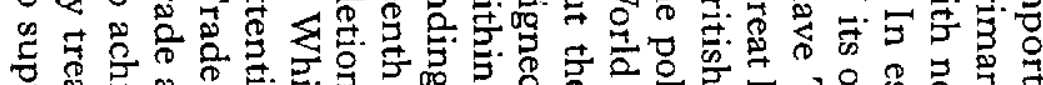

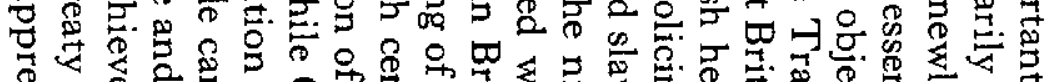

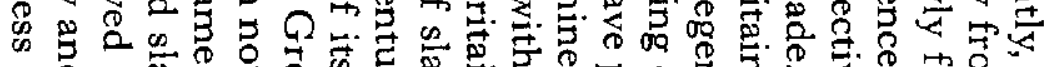

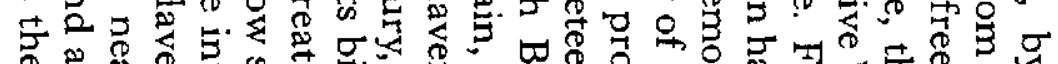
क

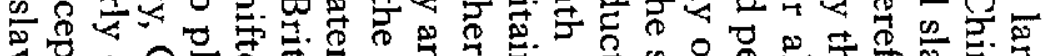

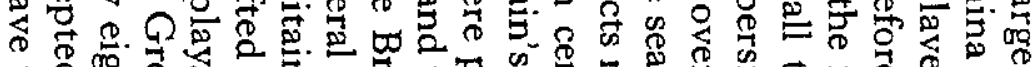

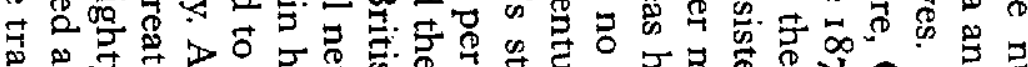

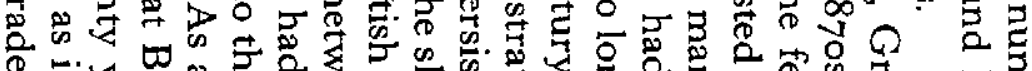

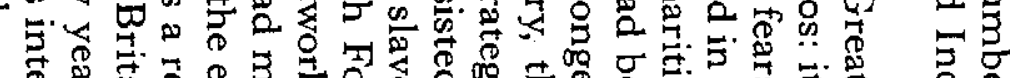

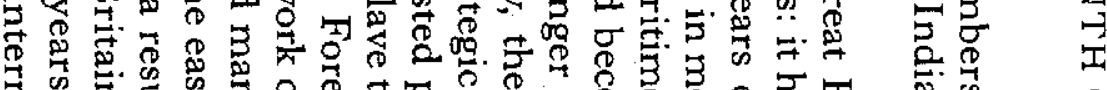
等

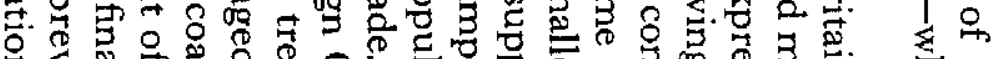

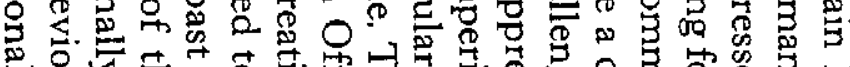

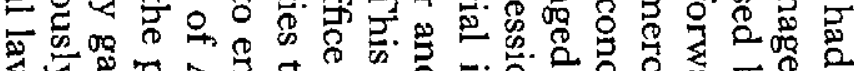

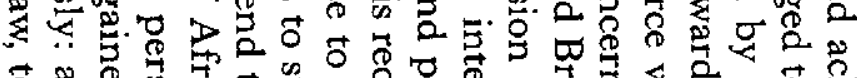

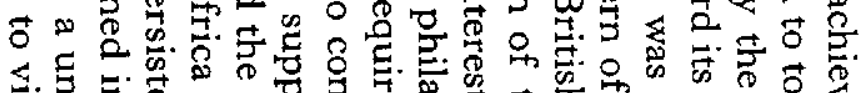

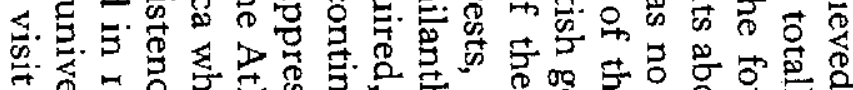
車 0

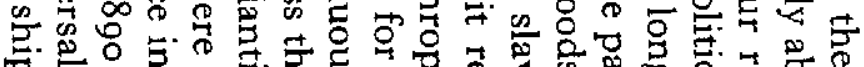

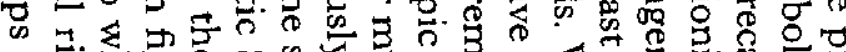

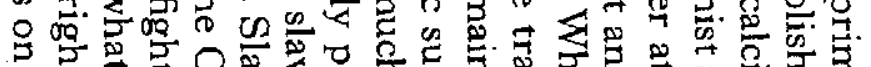

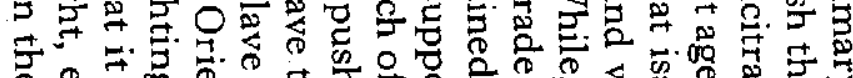

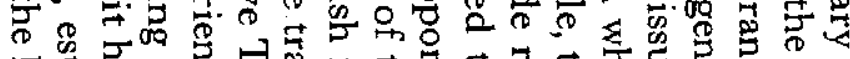

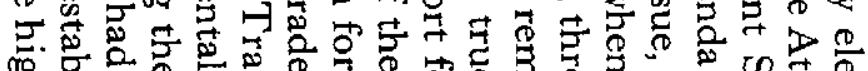

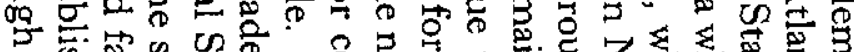

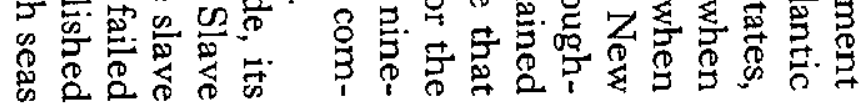
它 울 矛 要㕝

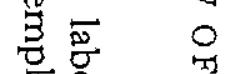
贾 $\stackrel{5}{\leftrightarrows}$ 宽寄 


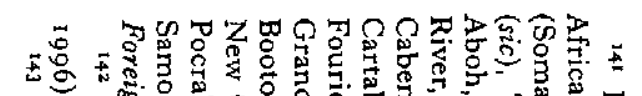

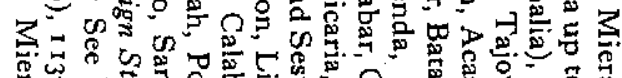
6.

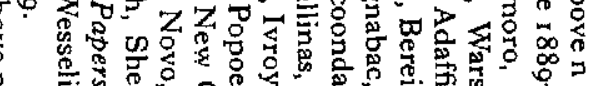
要

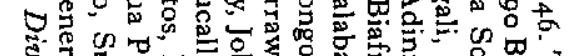

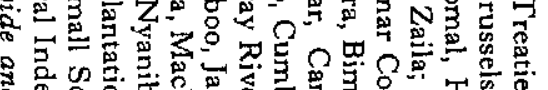

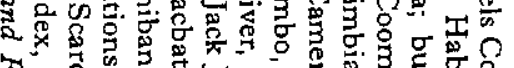

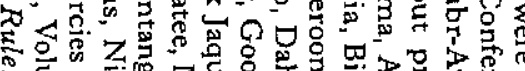

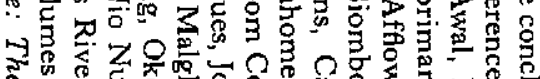

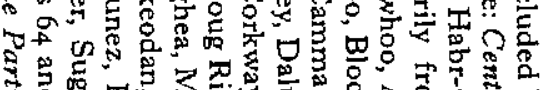

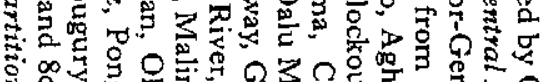
9 000

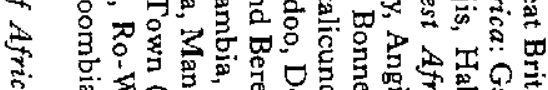
क N

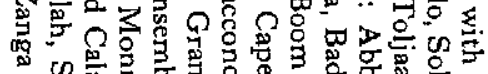

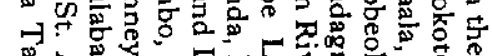

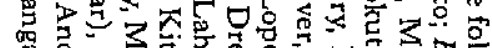

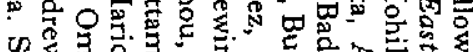
का

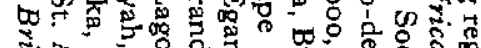
空일

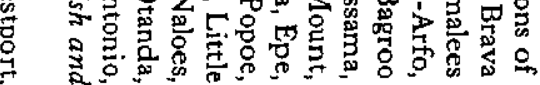

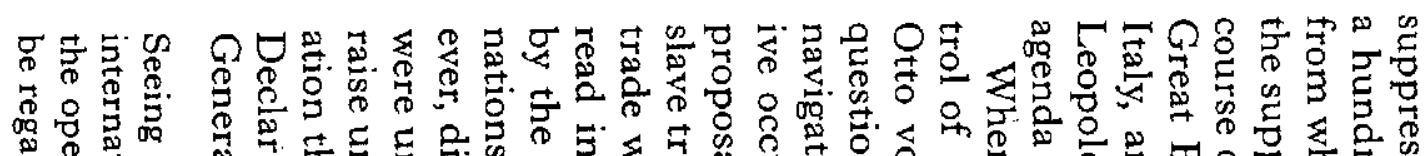

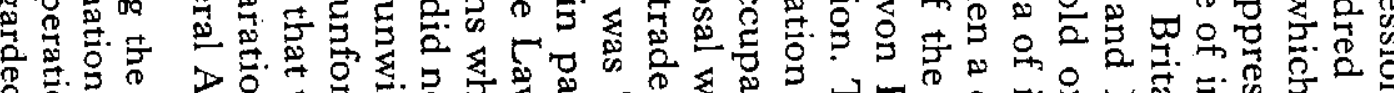

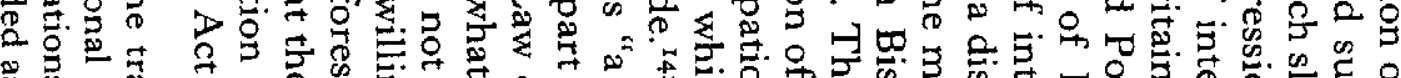

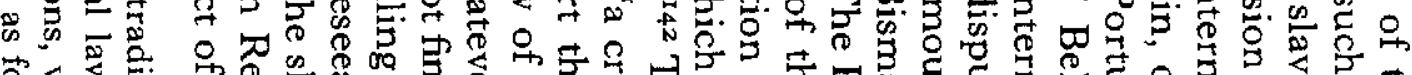

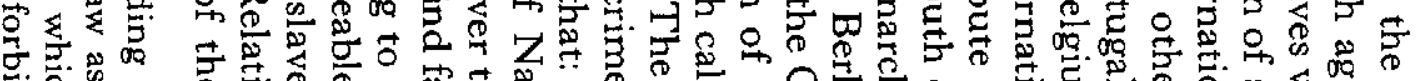

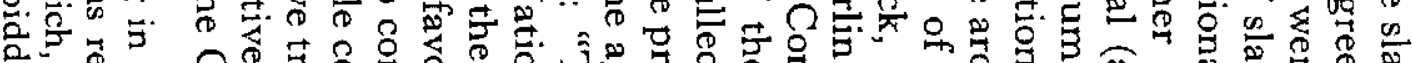

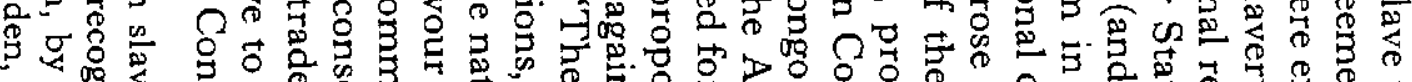

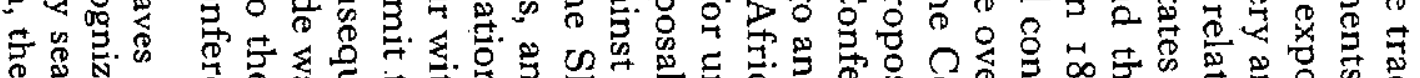

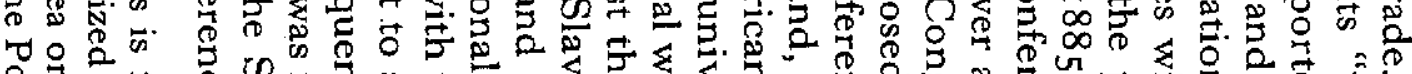

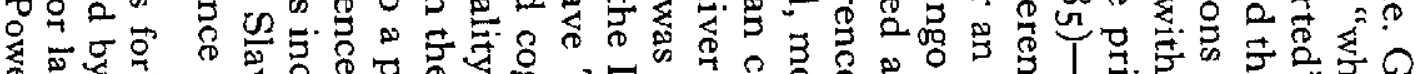

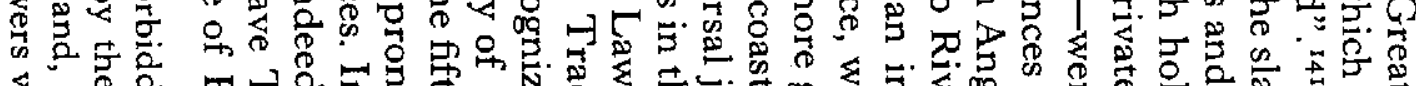

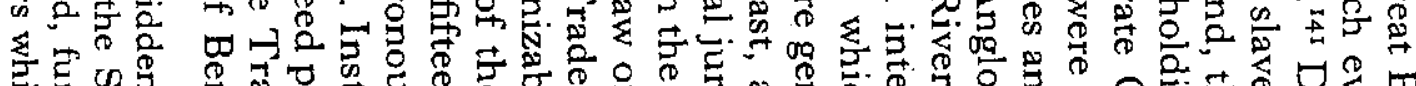

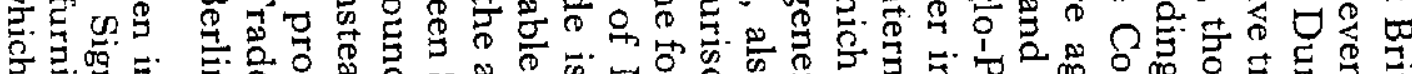

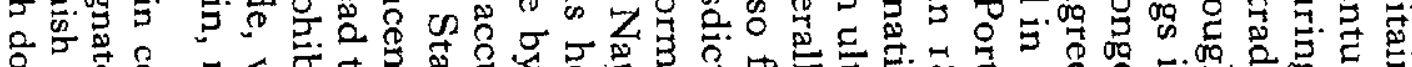

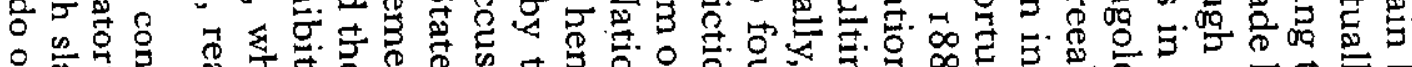

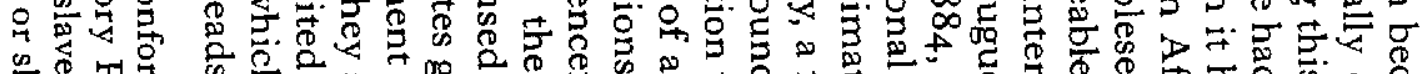

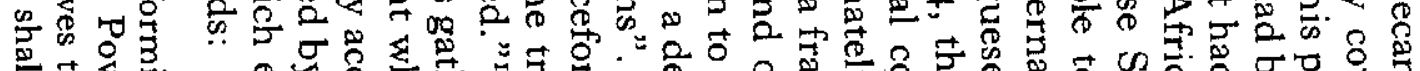

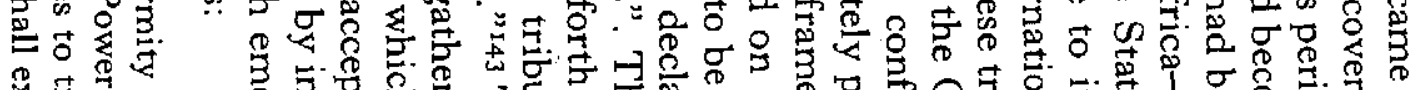

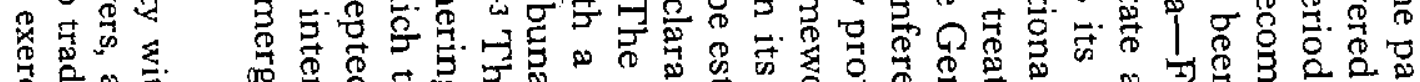

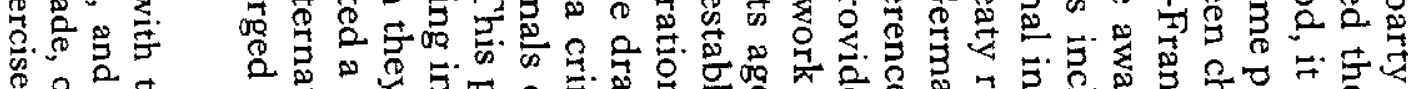

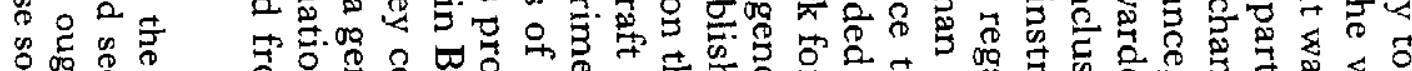

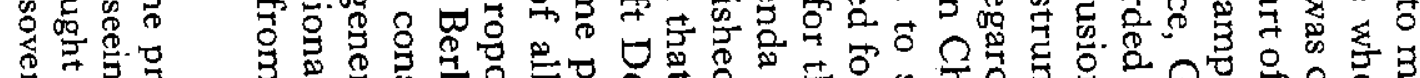
要品.

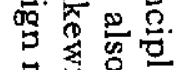
ב..

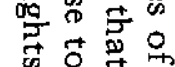

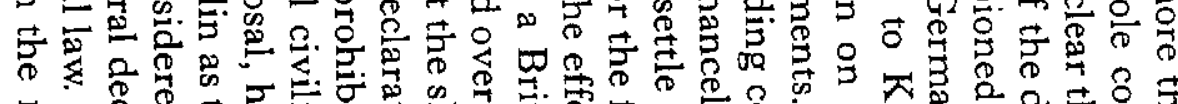

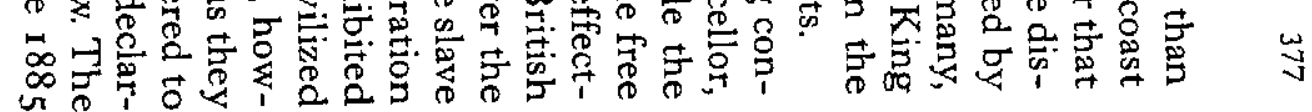




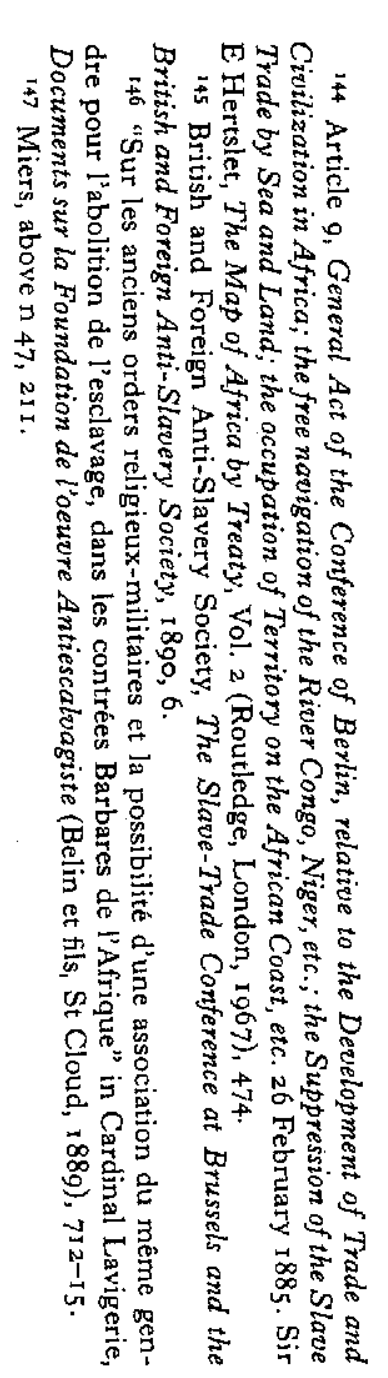

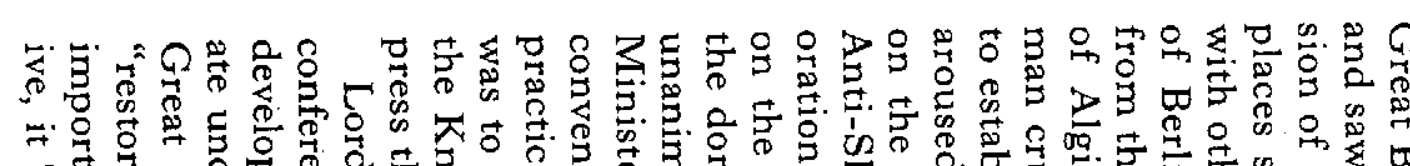

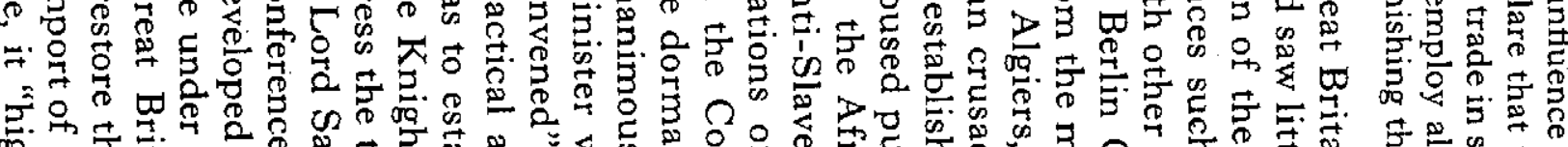
产.

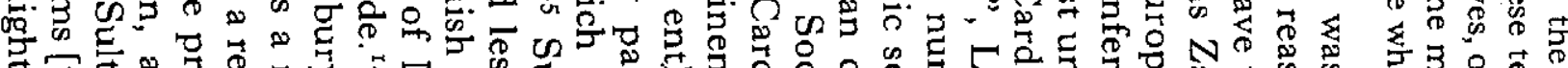

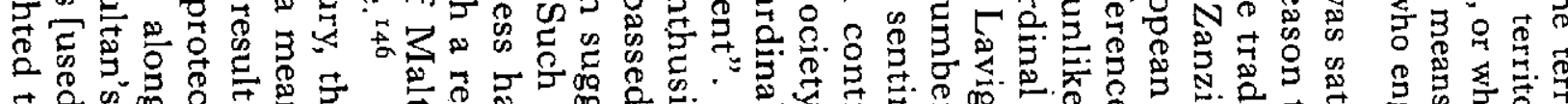

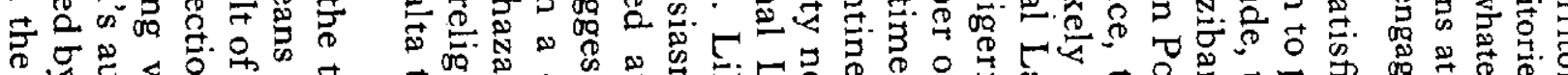

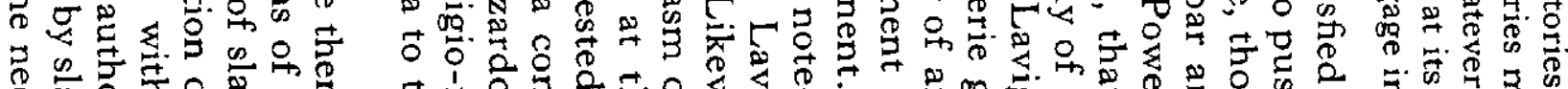

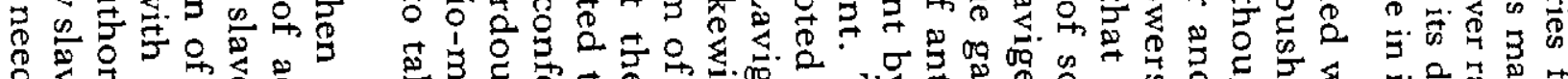

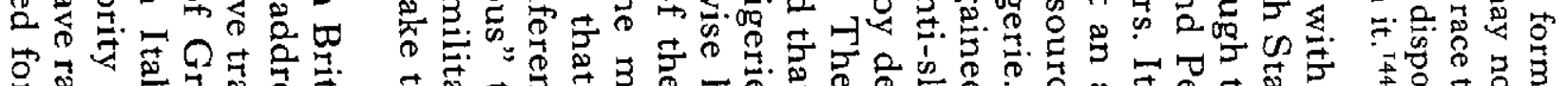

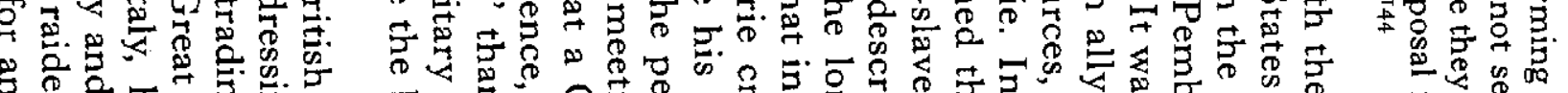
马 0.5

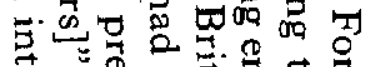

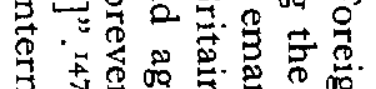

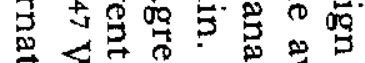

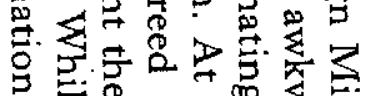

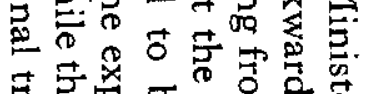

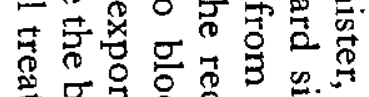
द

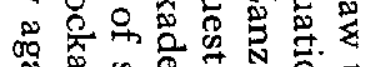
焉.

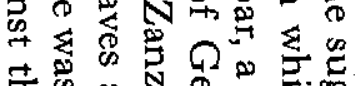

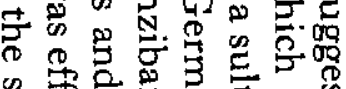

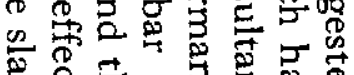

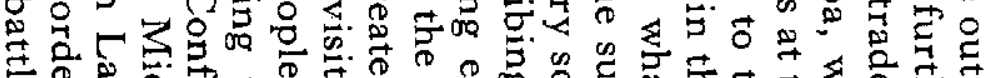

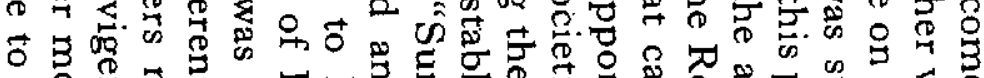

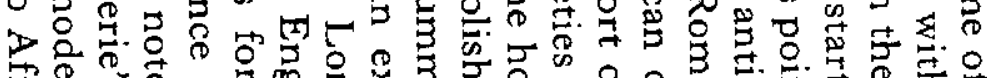

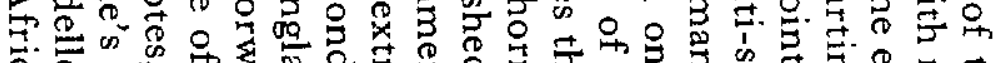

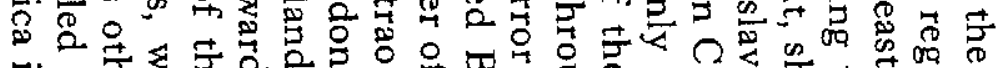

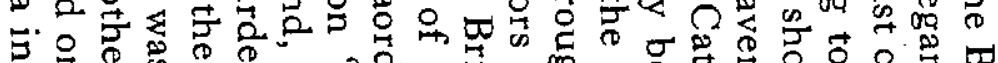
类它

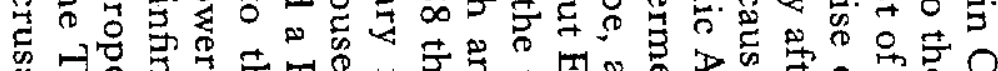

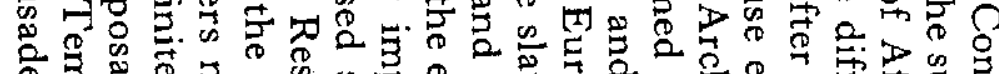

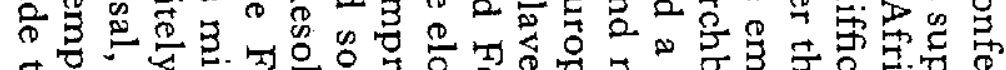

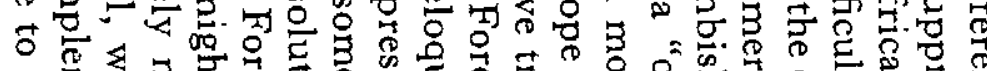

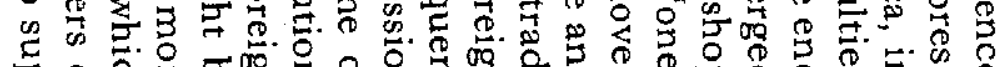
迅落 2 द. $\stackrel{3}{3}$

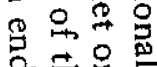
क 豈车罗吉 $\rightarrow \mathrm{s}$

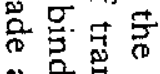

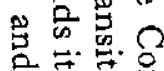

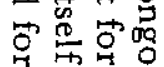



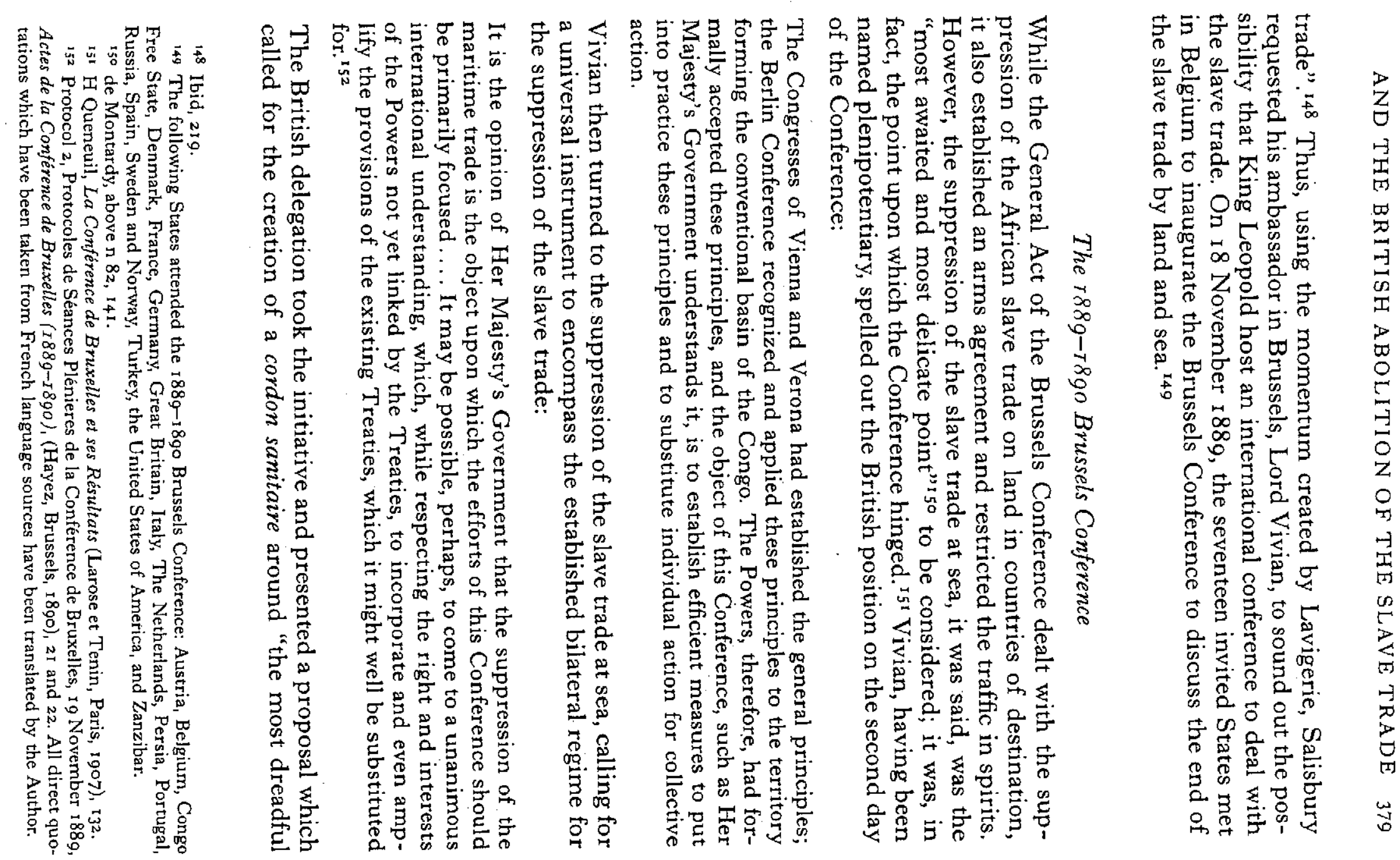


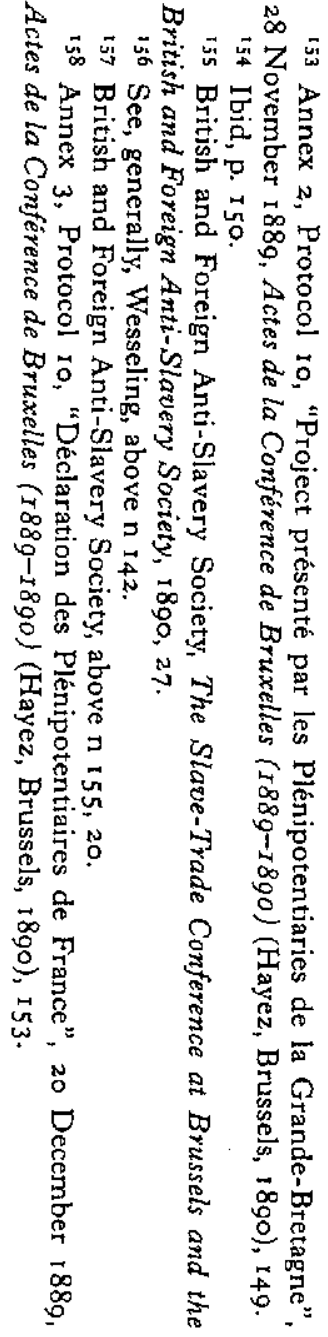

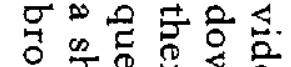

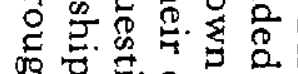

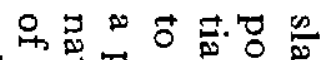

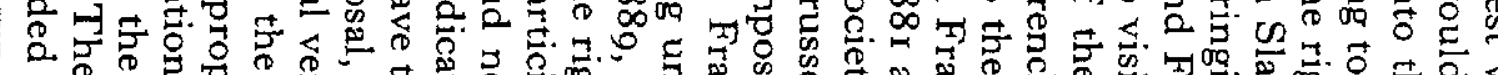

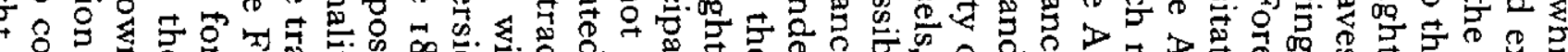

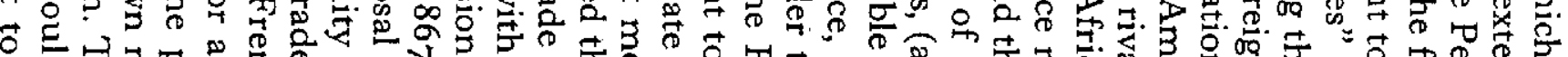

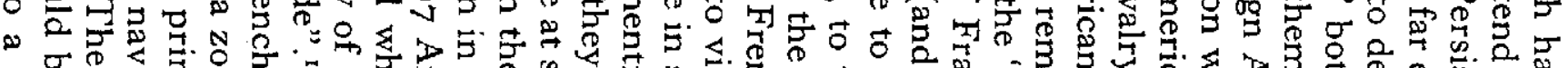

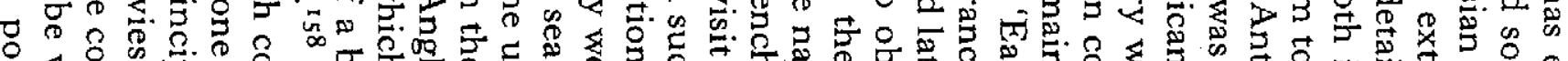
引

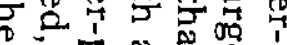

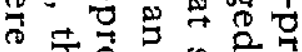

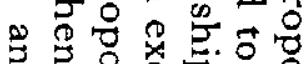

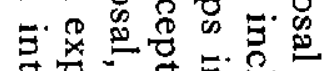

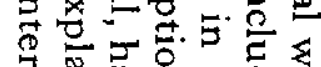

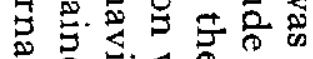
蒫. 象富

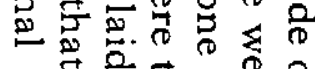

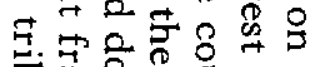

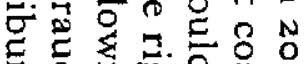

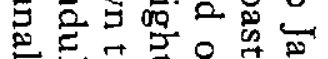

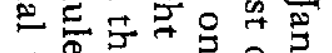

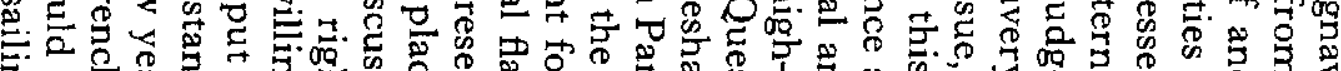

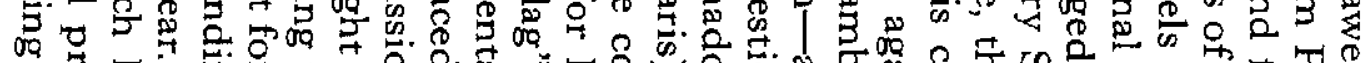

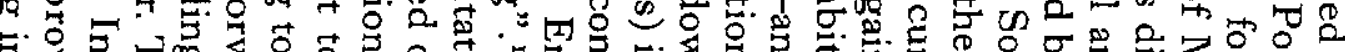

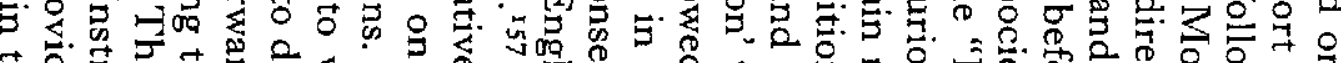

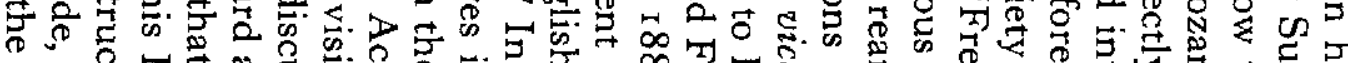

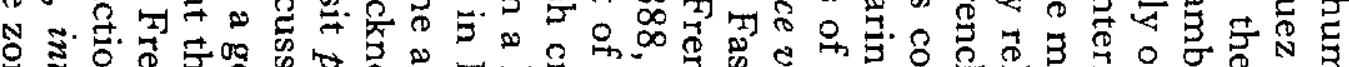

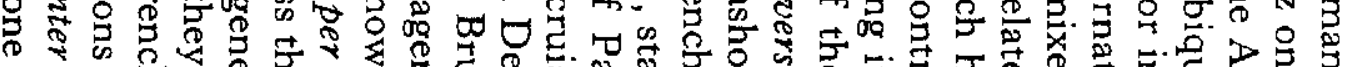

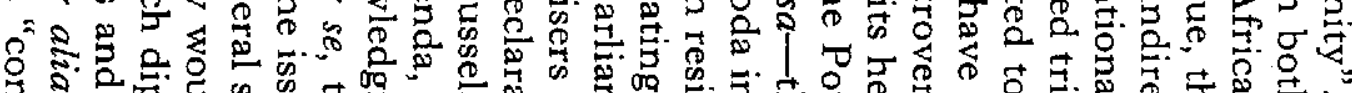

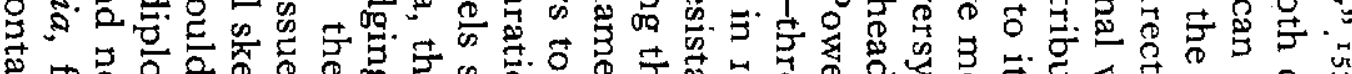

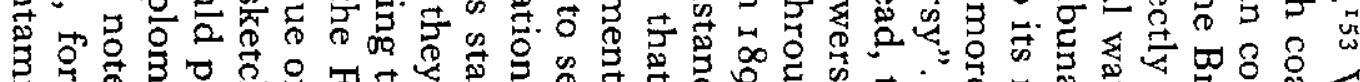

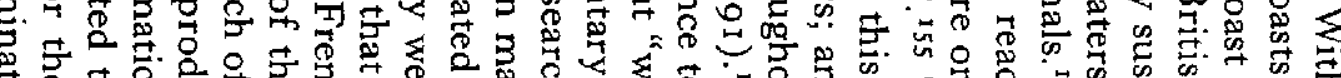

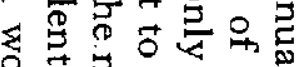

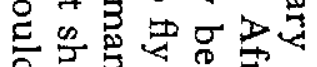

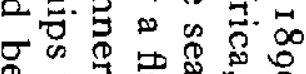

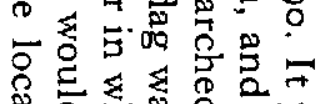

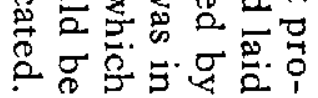

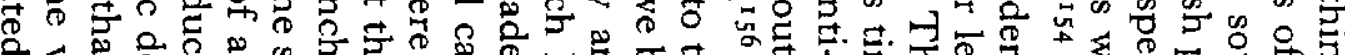

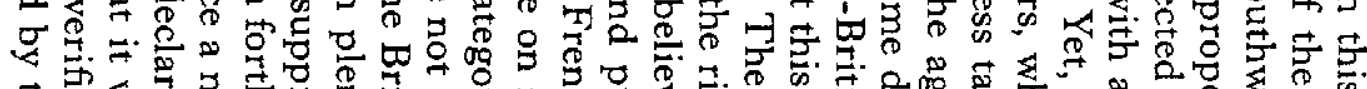
대 350

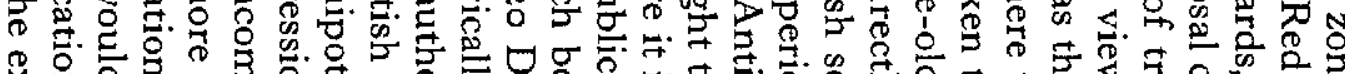

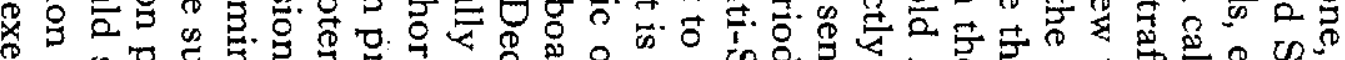

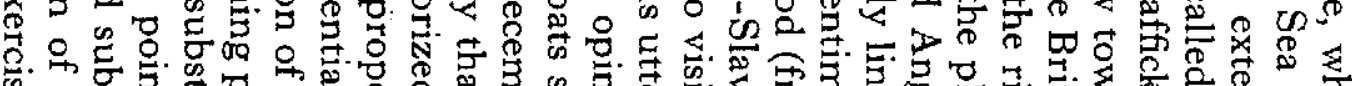

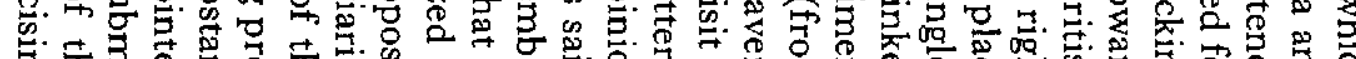

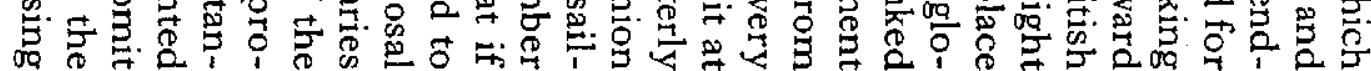




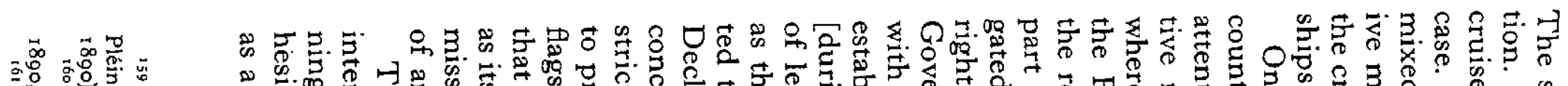

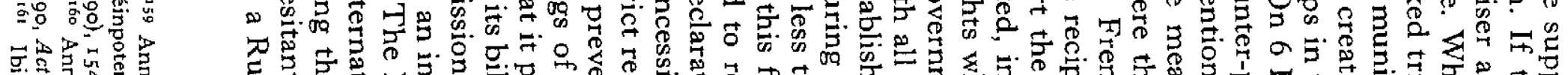

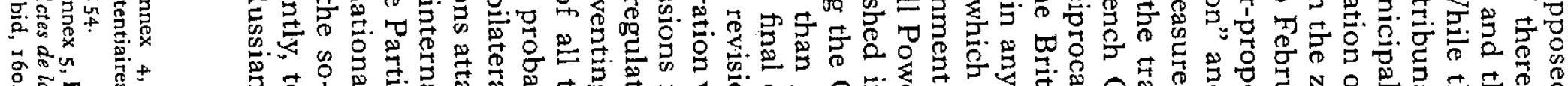

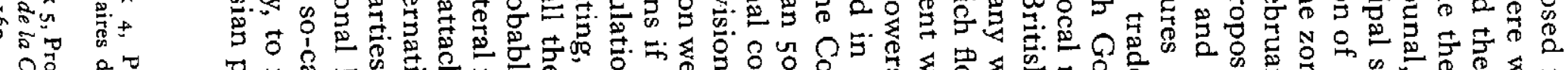

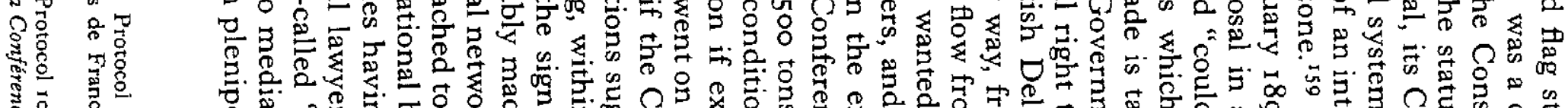

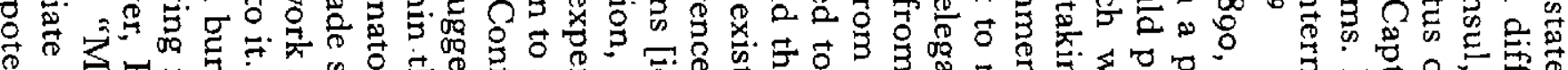

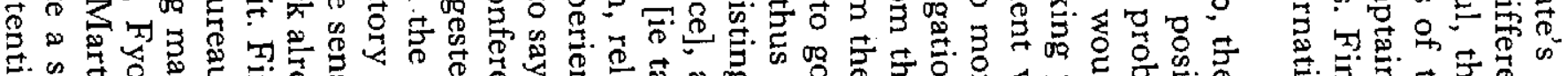

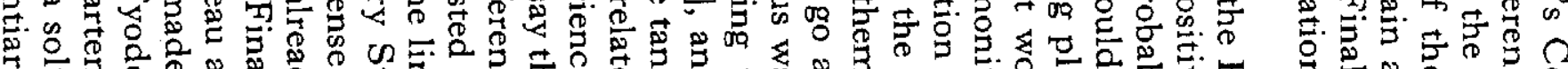

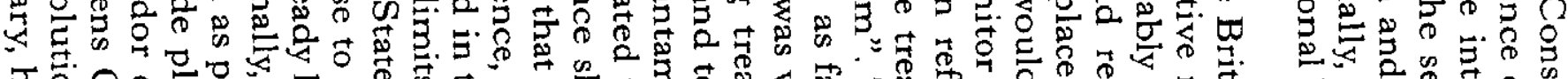

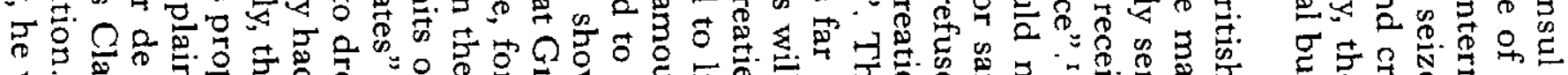

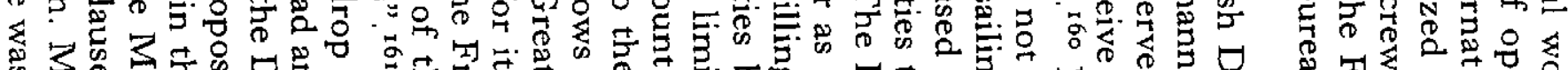

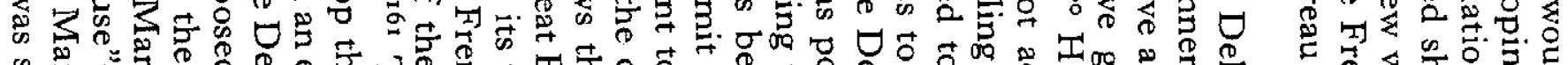

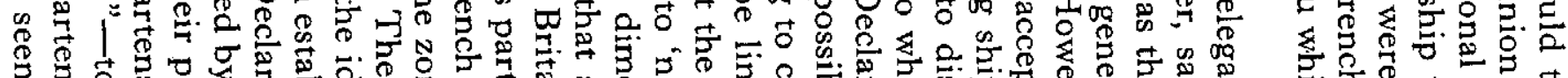

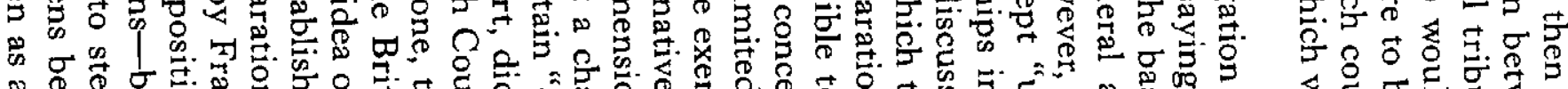

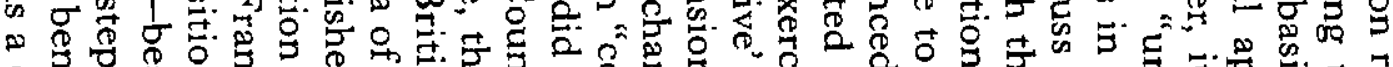

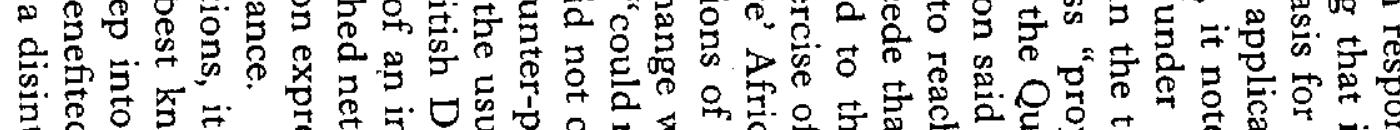

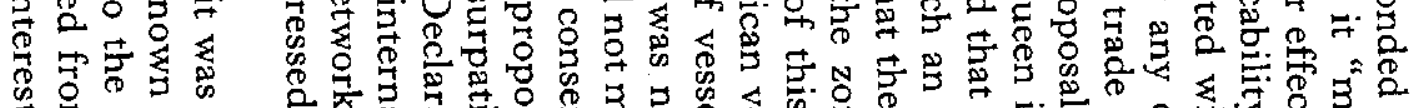

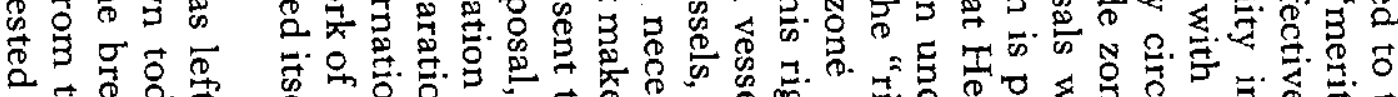

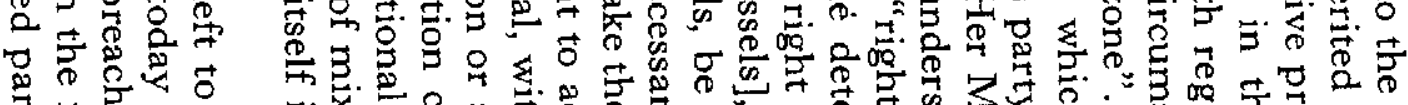

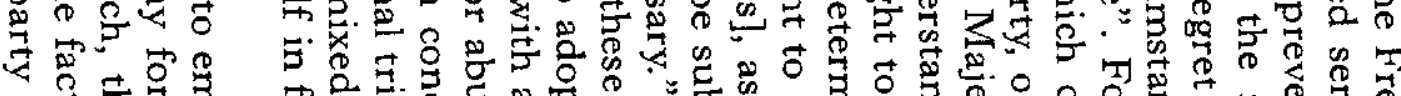

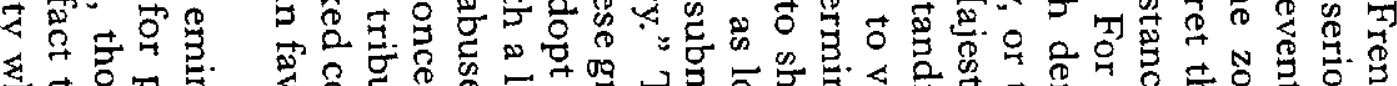

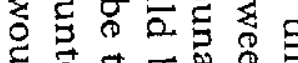

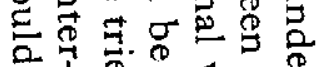

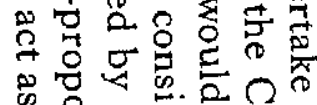
क

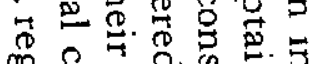

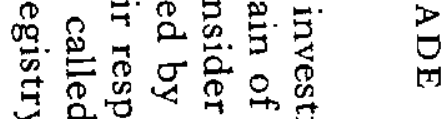

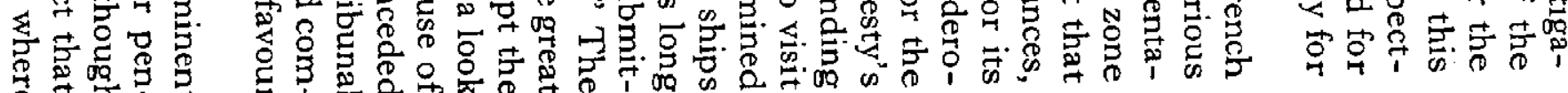




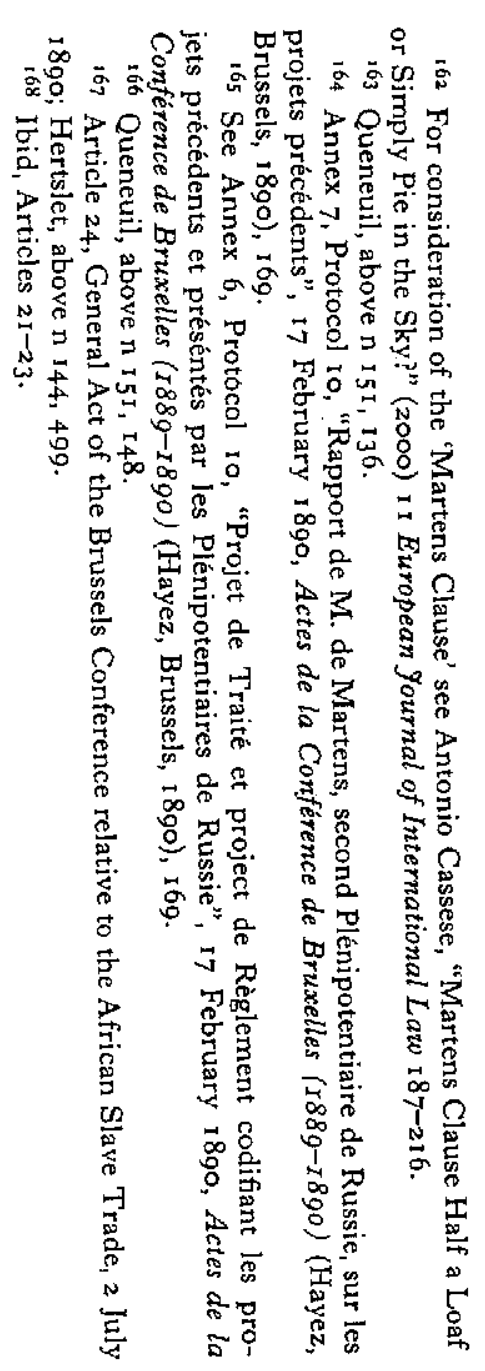

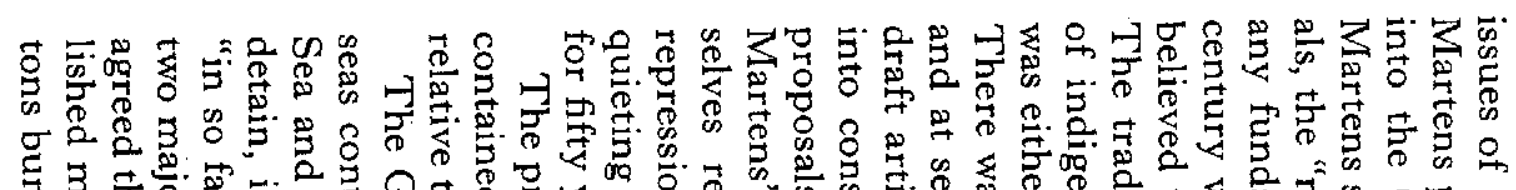

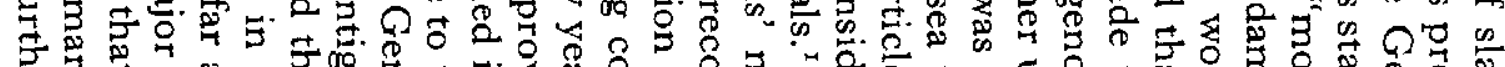

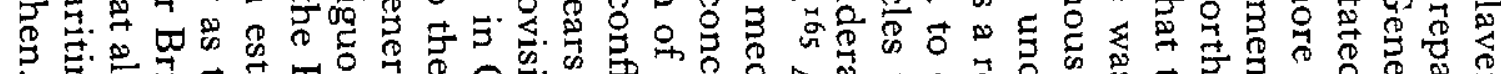

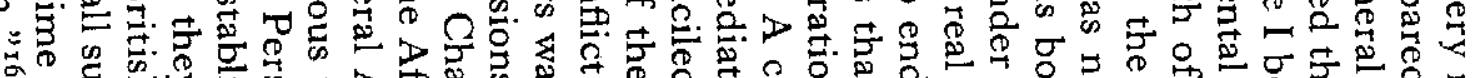
N

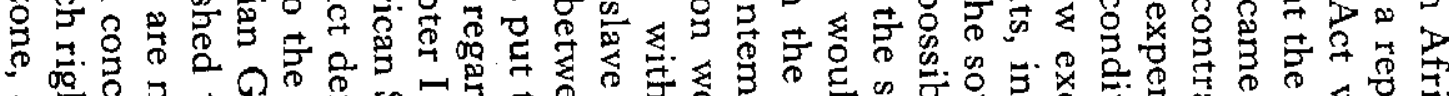
을

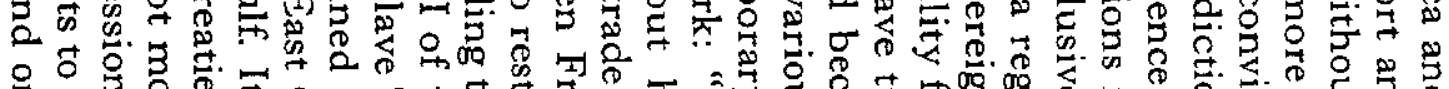

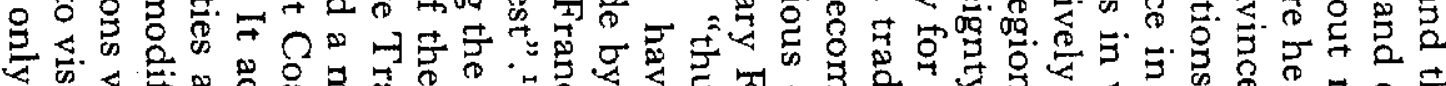

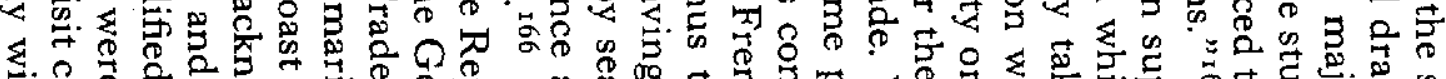

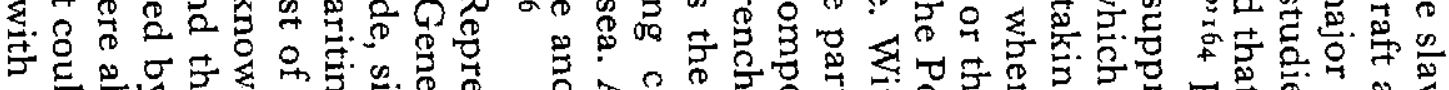

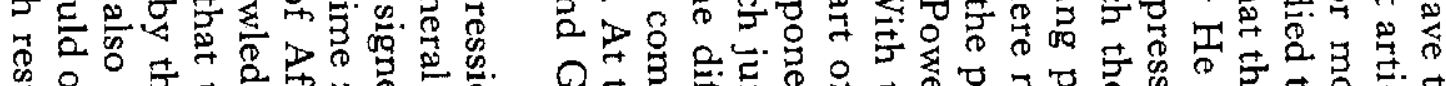

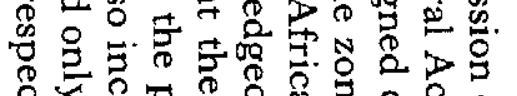

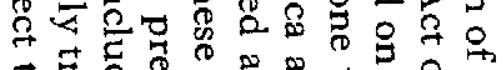

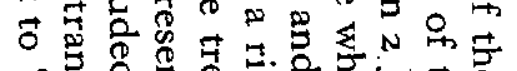

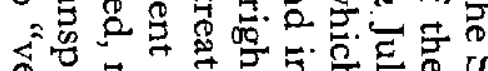
象. क⿺辶大

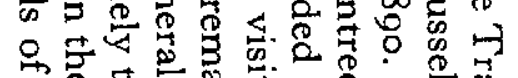

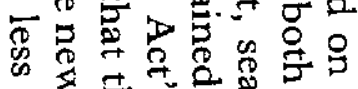

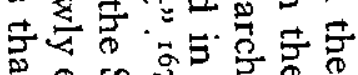

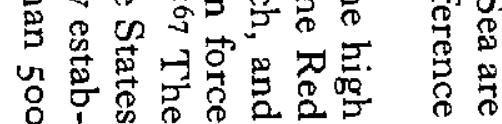

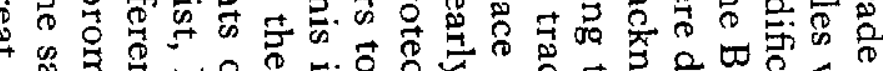

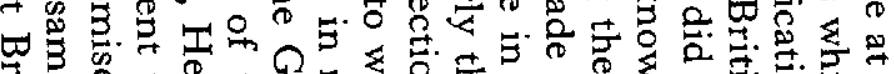
证.

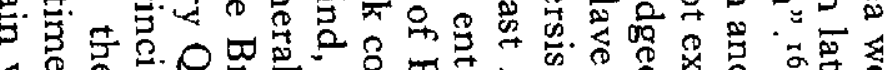
주의.

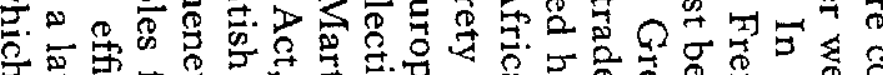

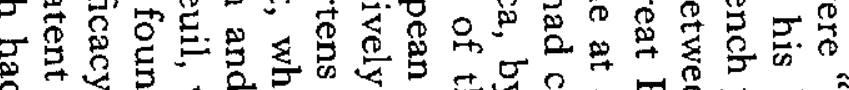
20

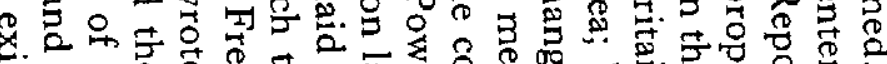

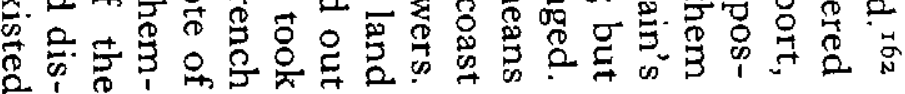
( 


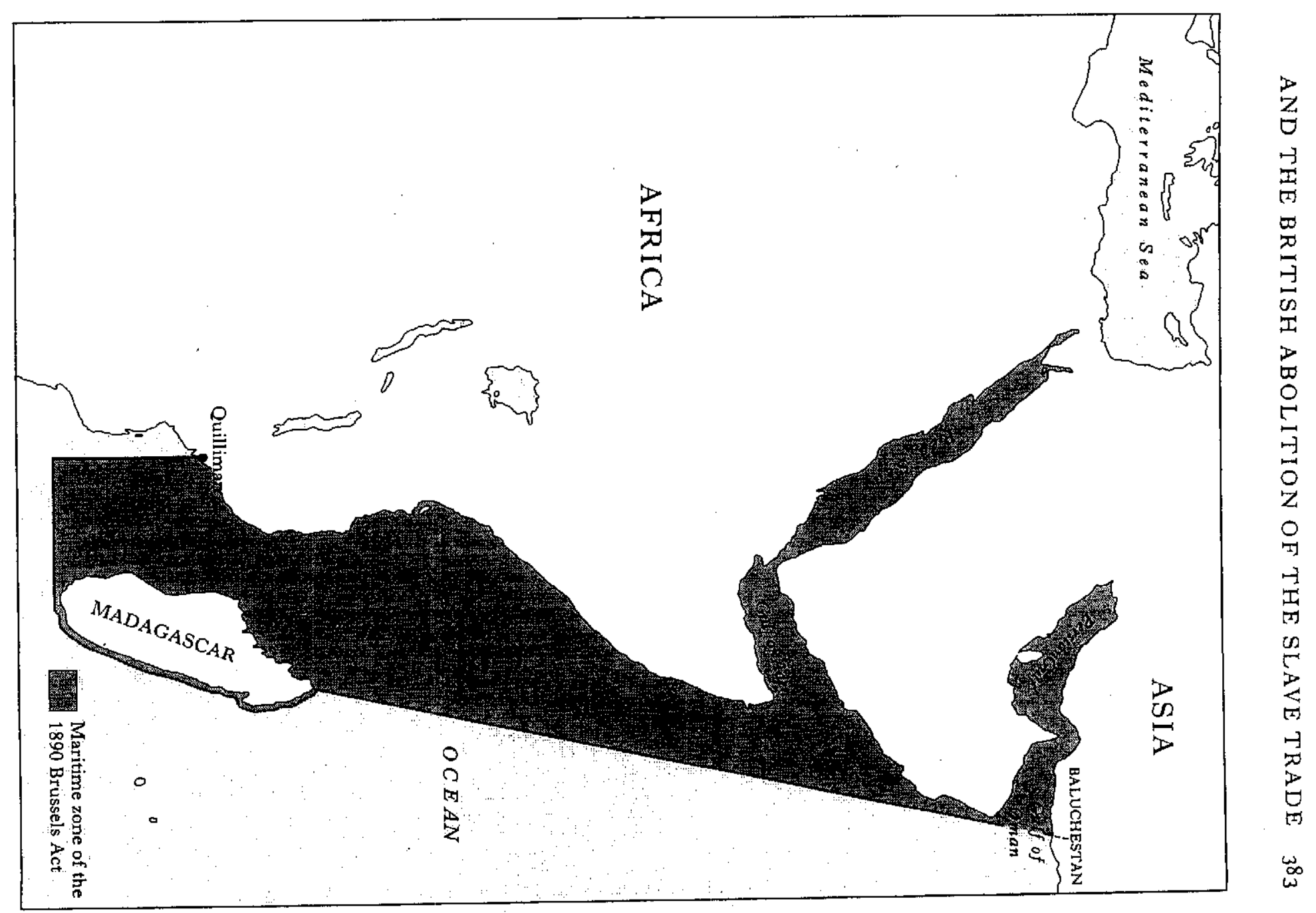




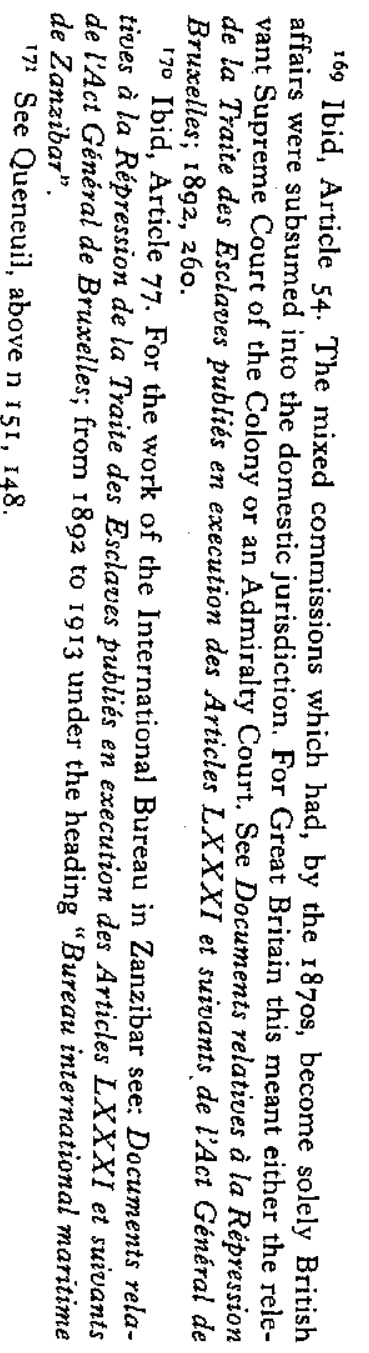

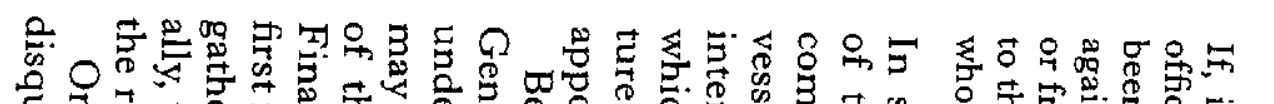

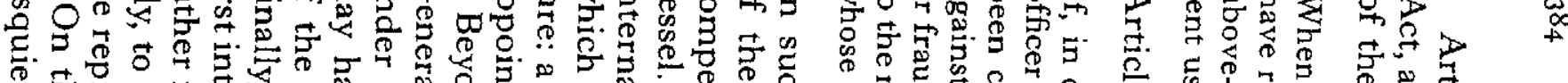

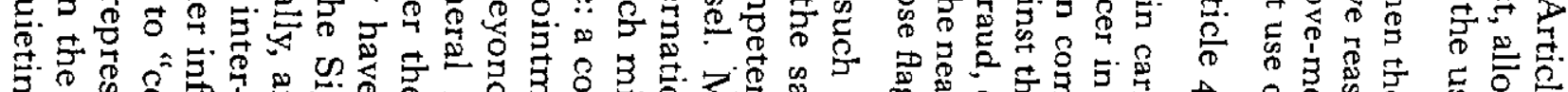

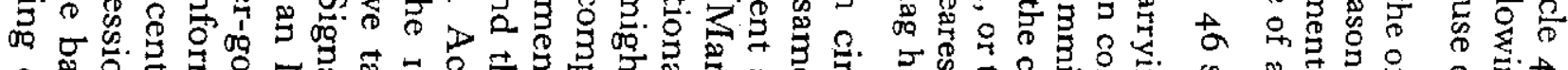

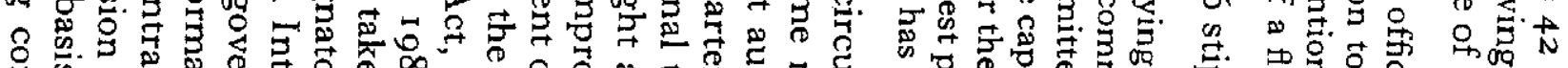

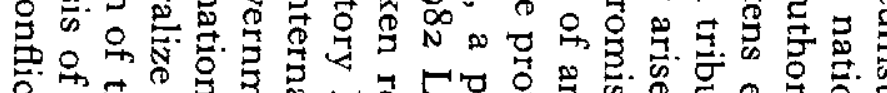

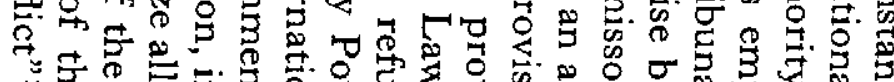

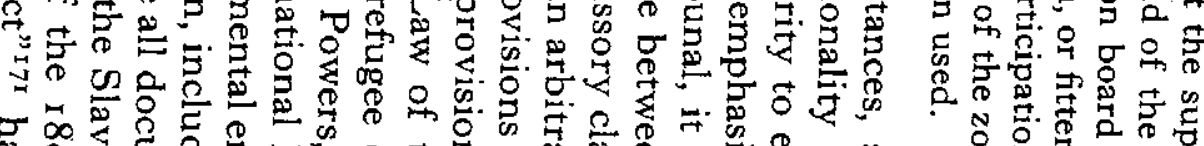

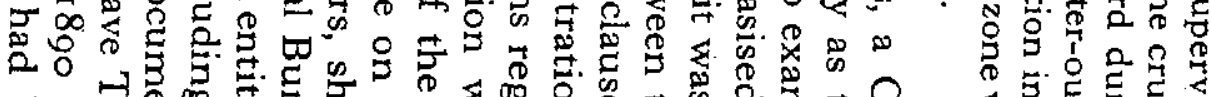

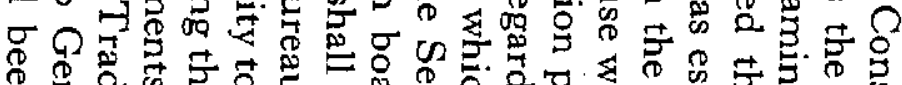

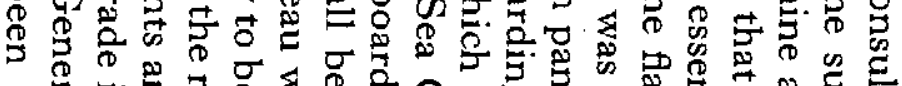

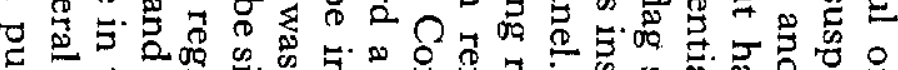

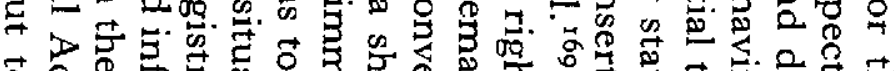

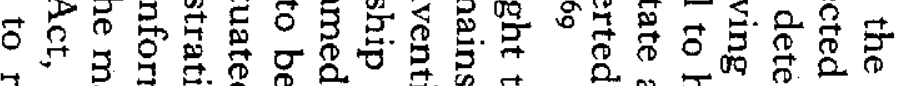

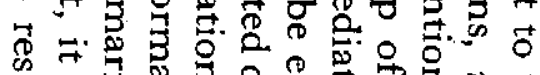

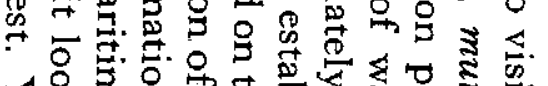

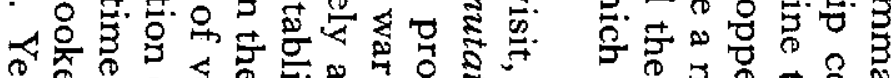

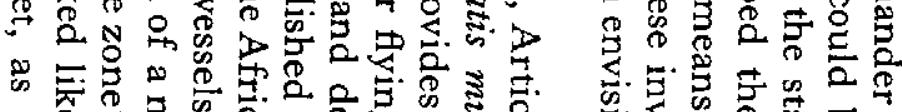

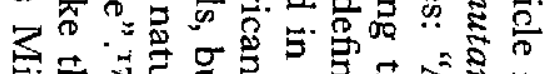
\%

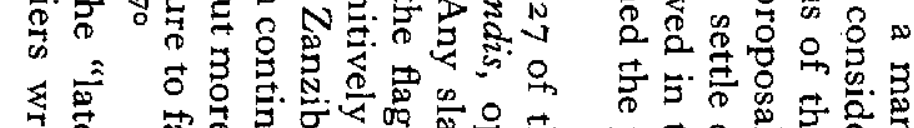

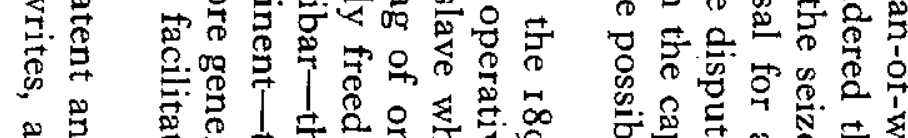

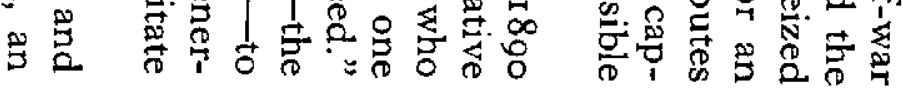

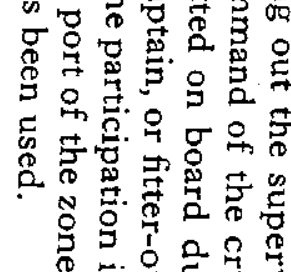

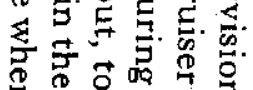
40

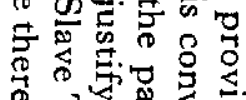

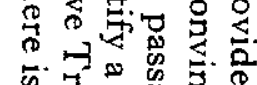
का

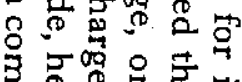
造

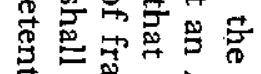

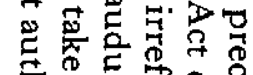

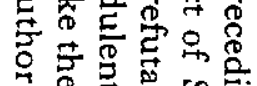

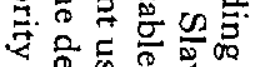

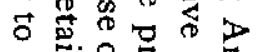

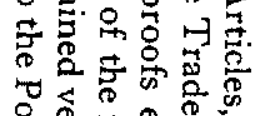

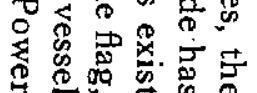

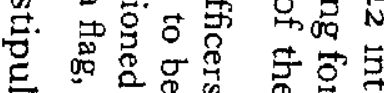

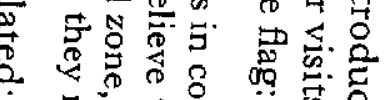

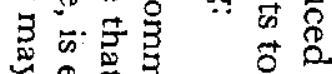

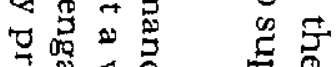

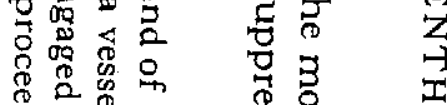

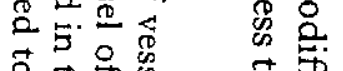

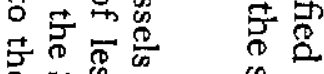
记员

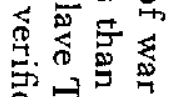

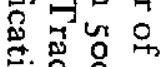

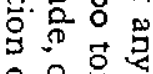
용요웡 守的茬官

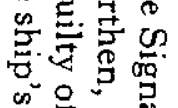

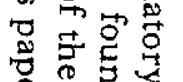

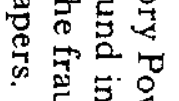
离苜 矛 के क्ष 25 홍 के $\$$ 密 宥客

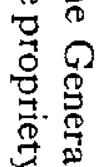




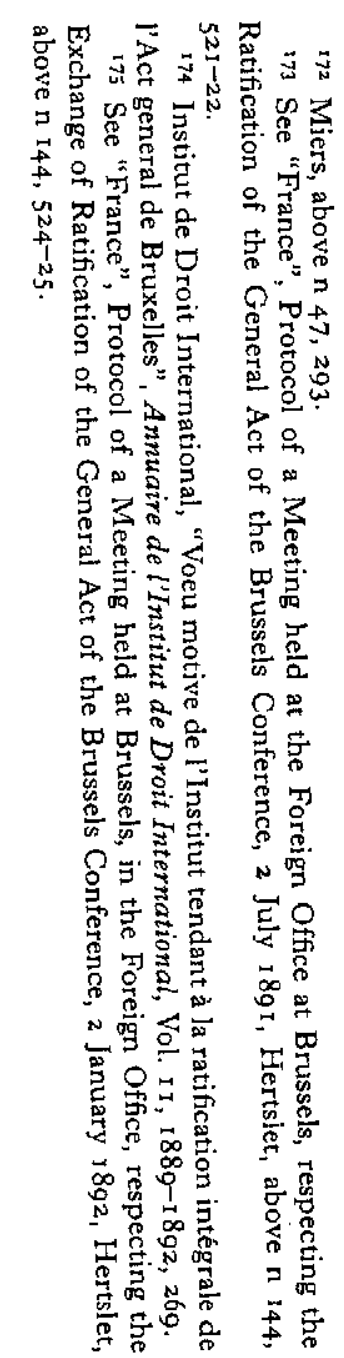

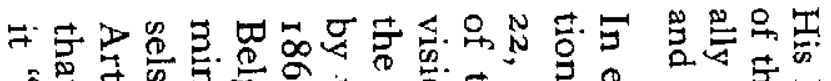

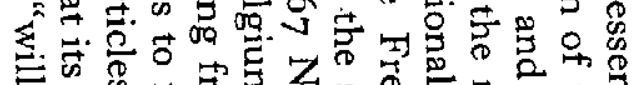

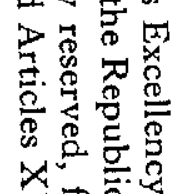

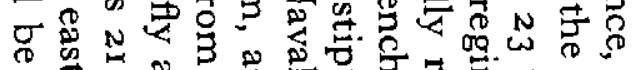
क त क

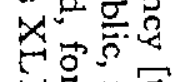

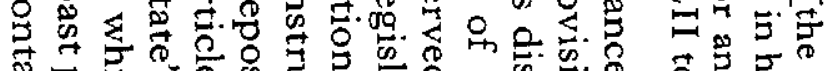

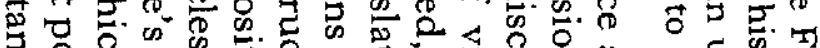
\%

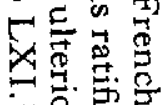

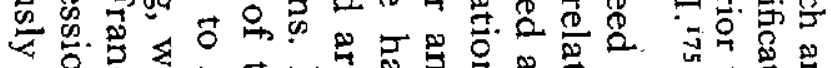

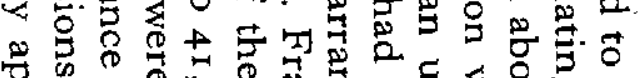

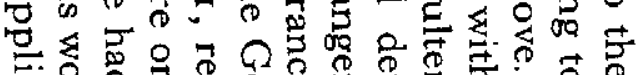

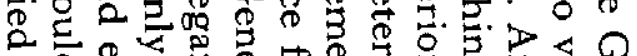

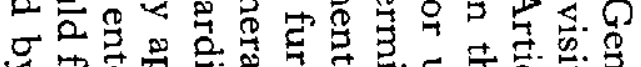

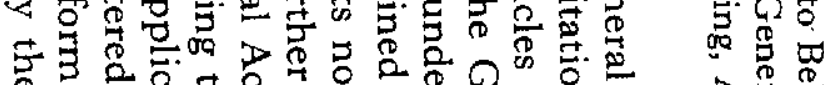

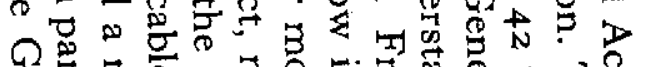

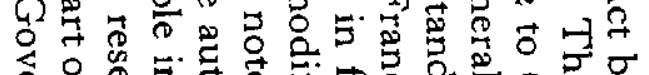

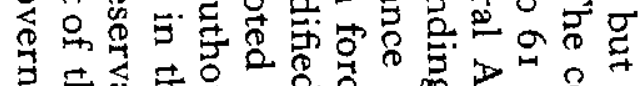

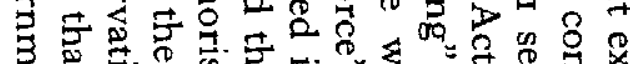

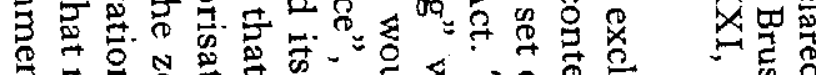
露

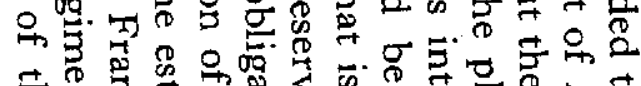

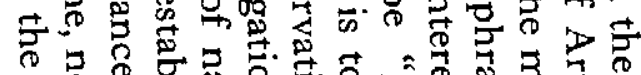

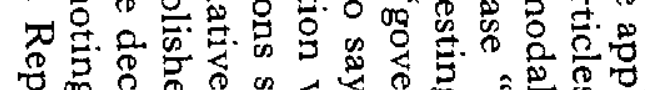

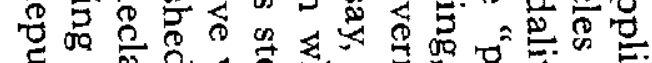

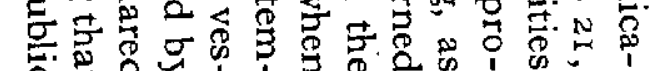
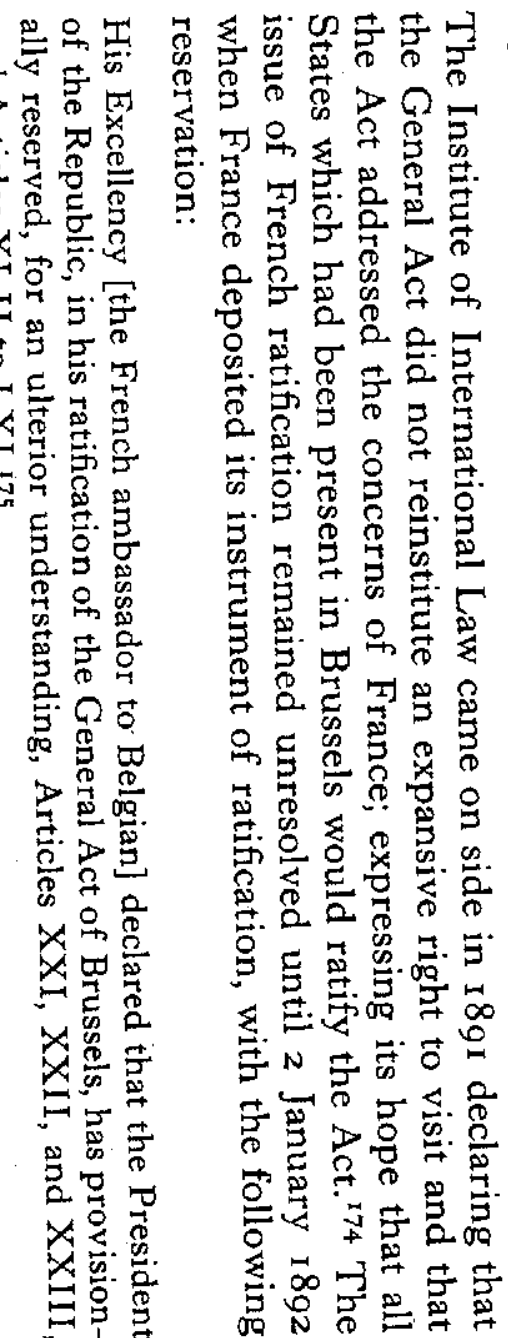

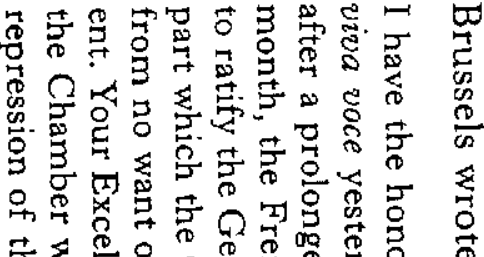




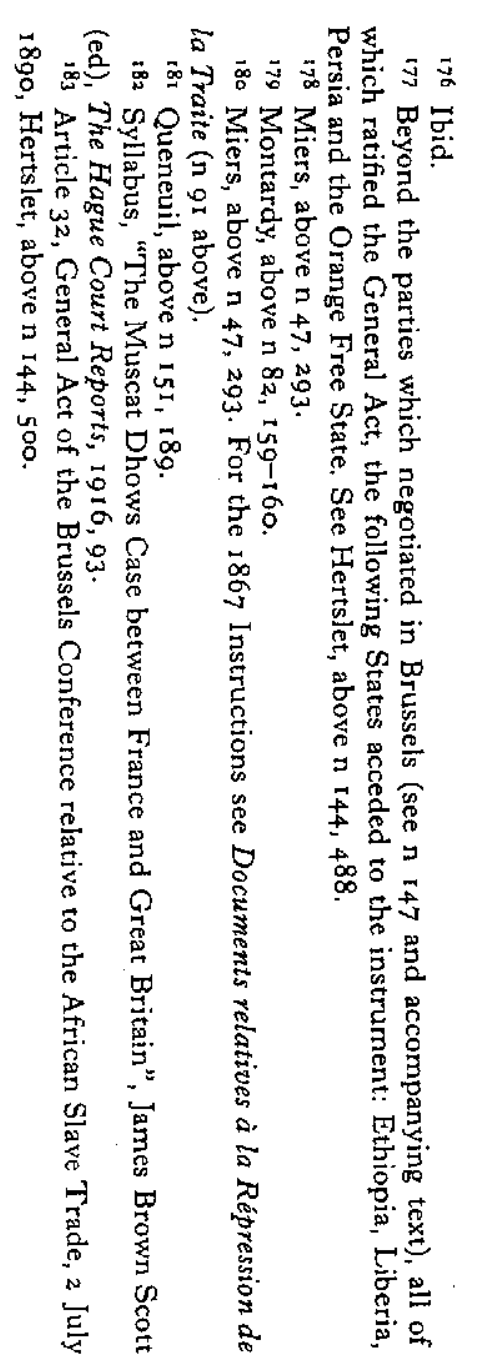

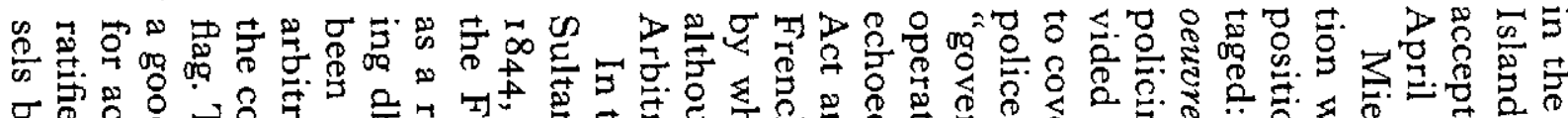

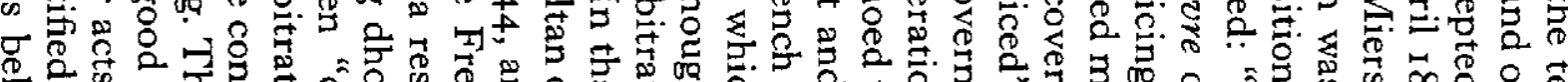

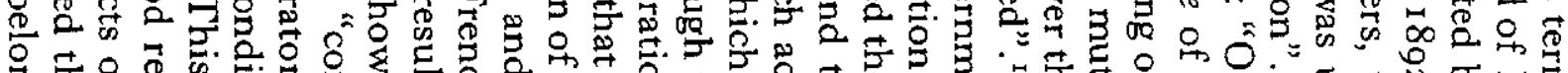

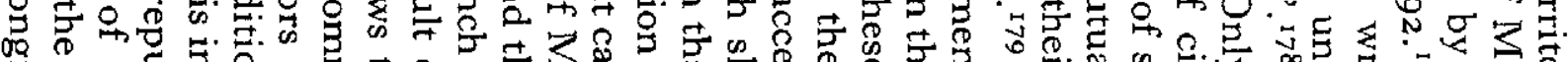

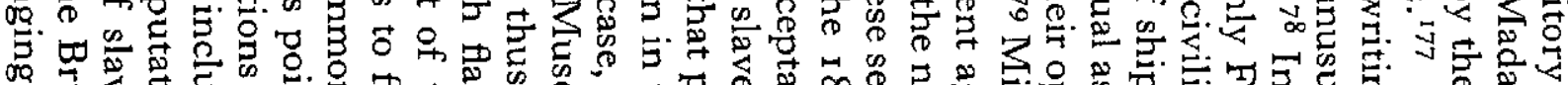

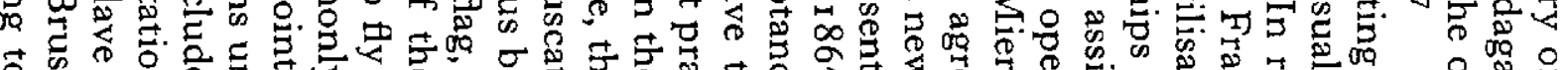

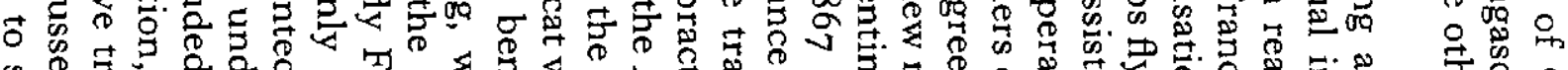

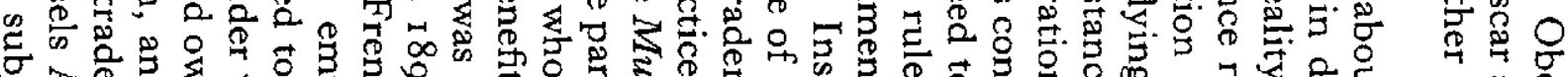

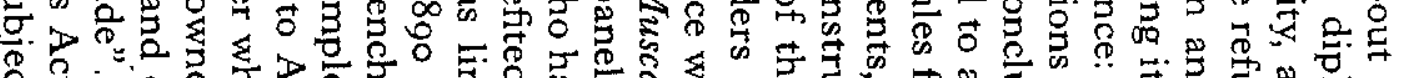

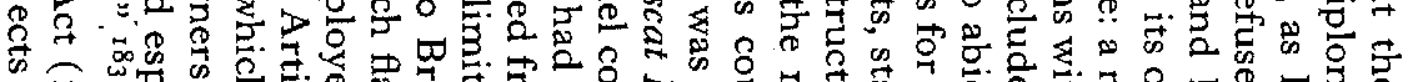

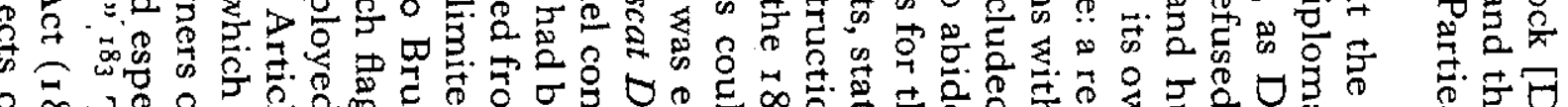

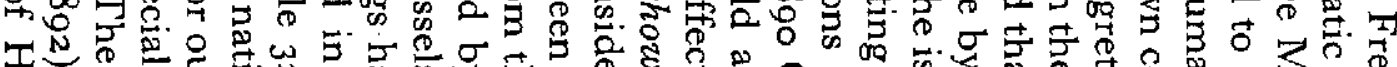

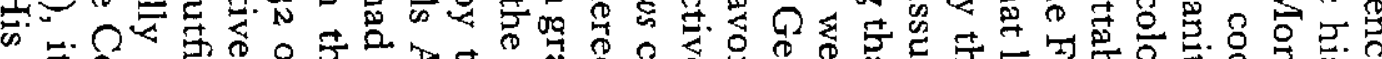

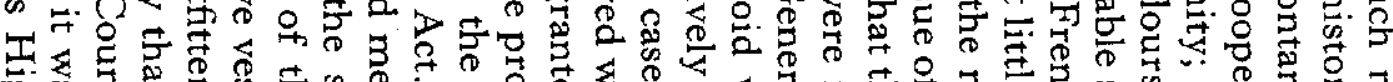

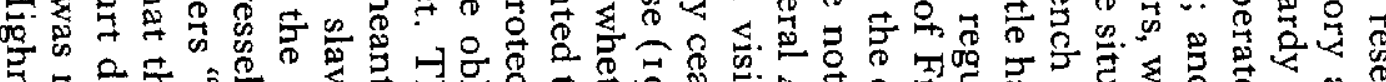

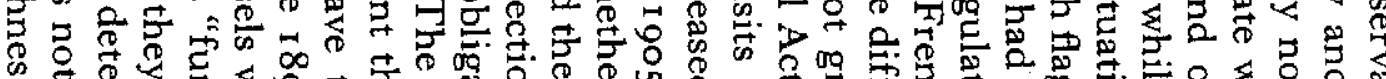

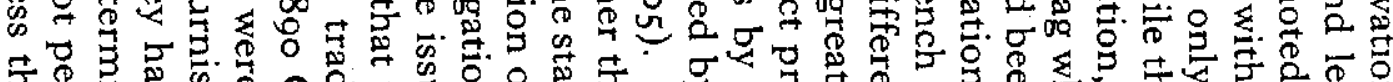

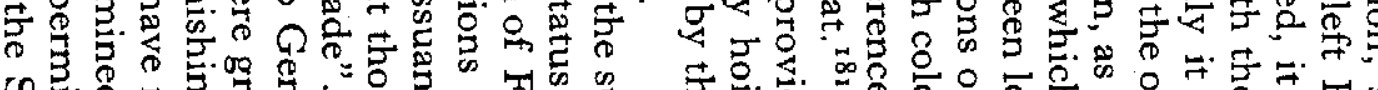

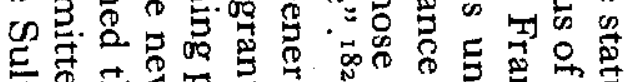

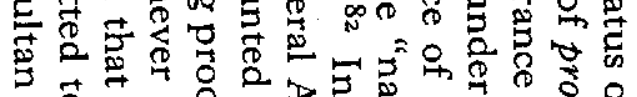

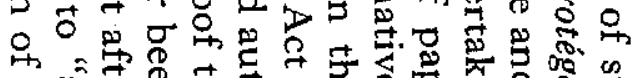

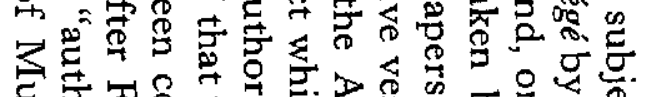

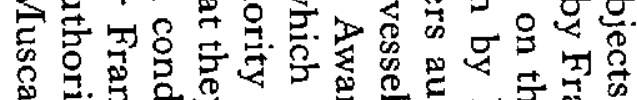

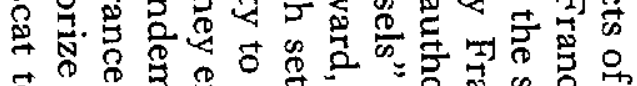

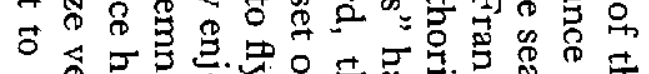

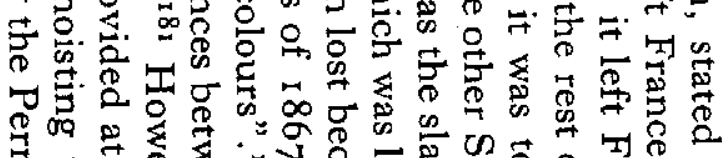

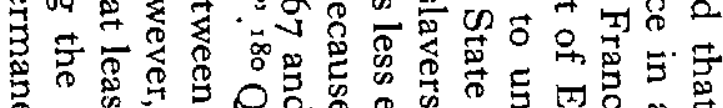

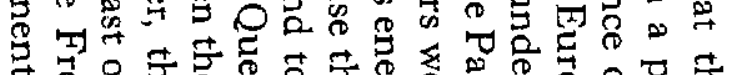

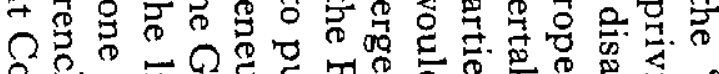

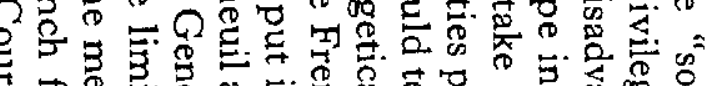

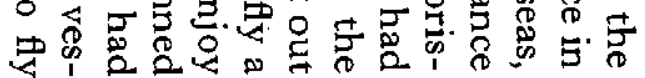

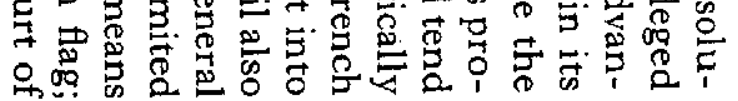

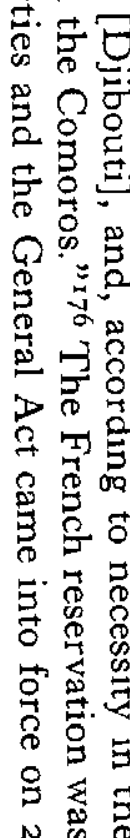




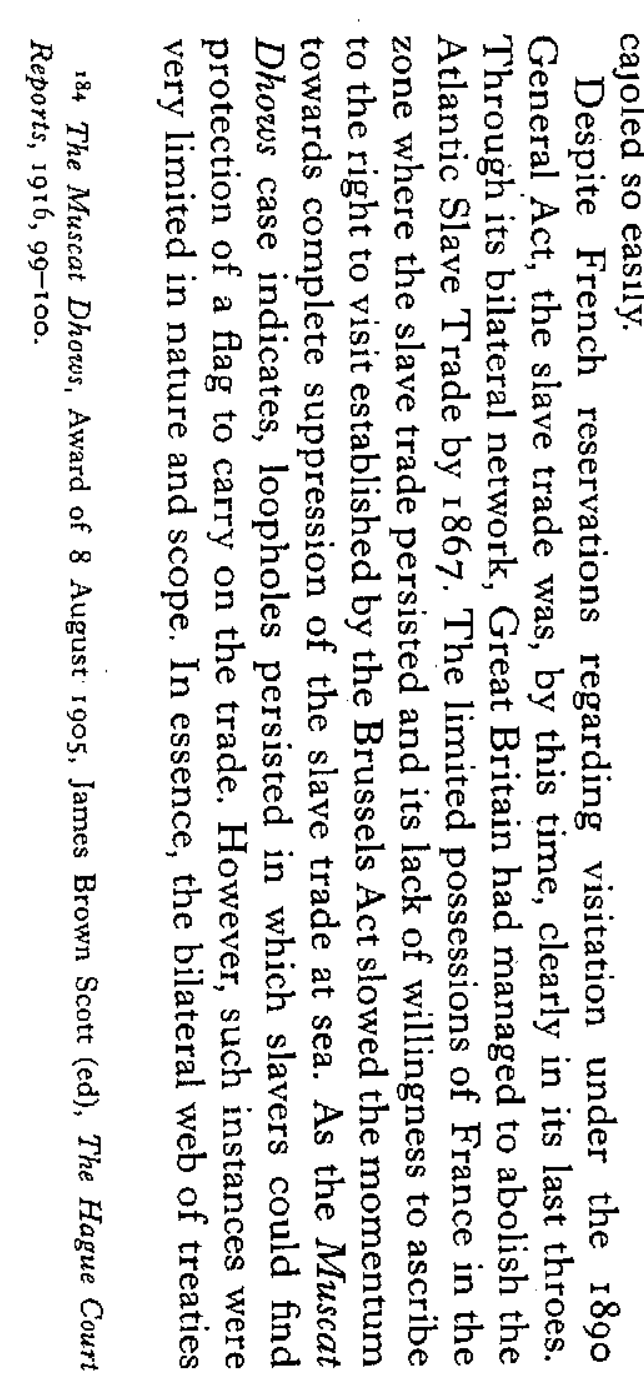

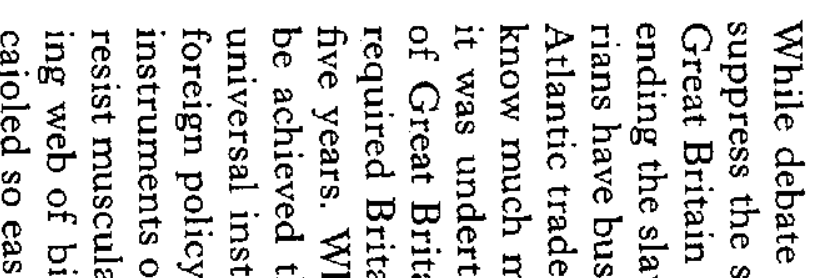

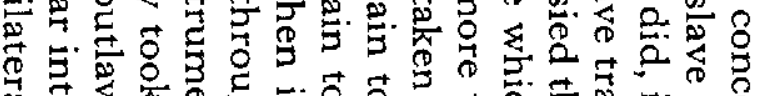

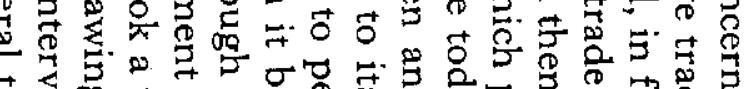

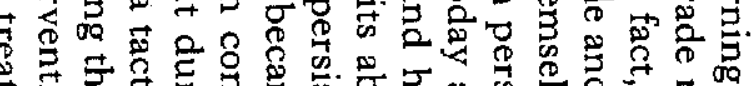

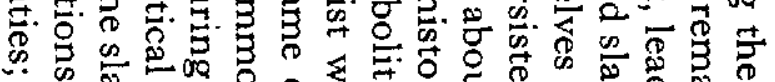

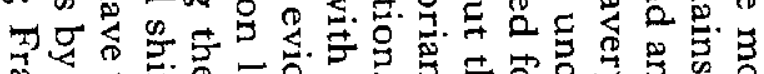

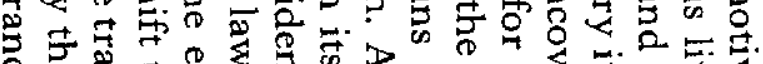

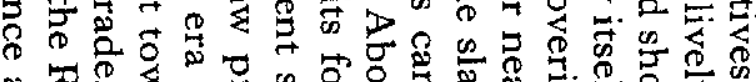

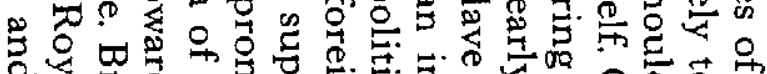

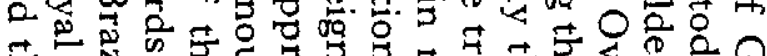

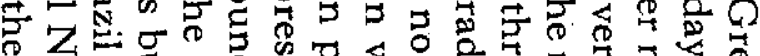

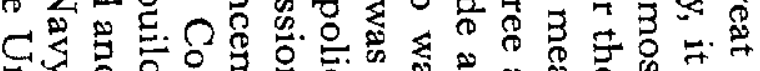

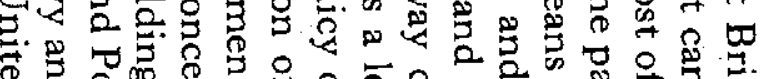

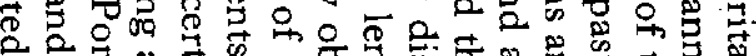

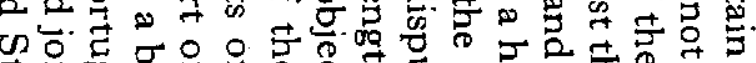

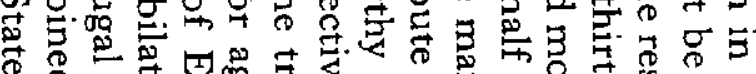

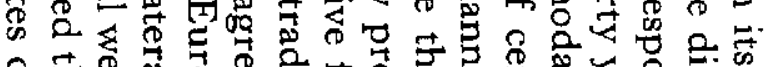

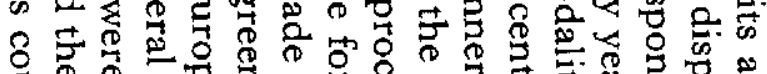
छ

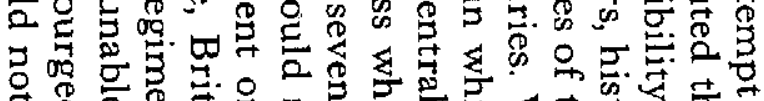

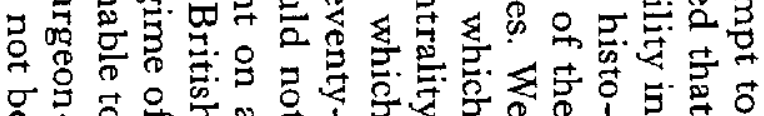

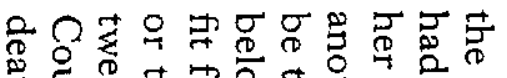

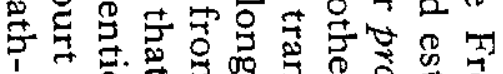

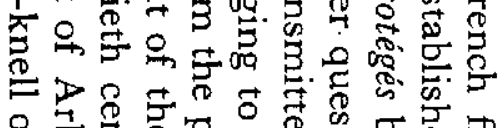

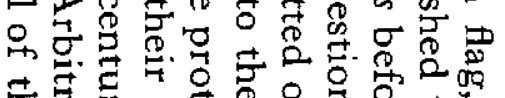

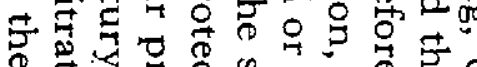

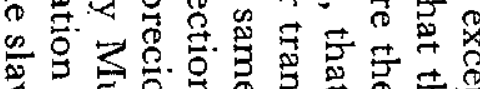

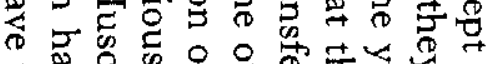

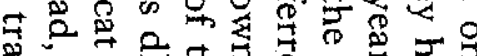
。

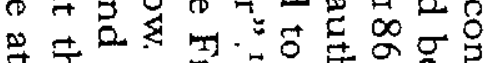

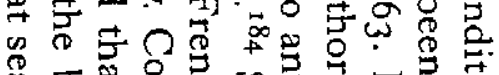

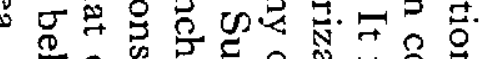

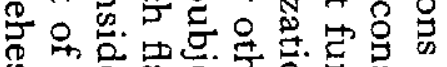

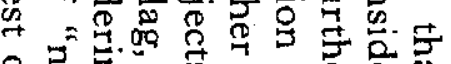

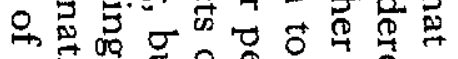

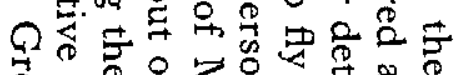

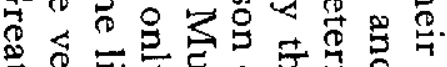

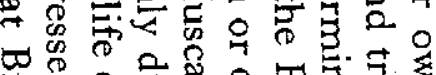

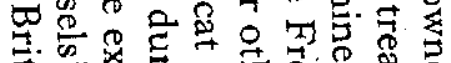

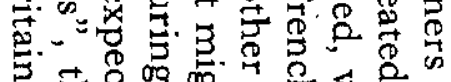

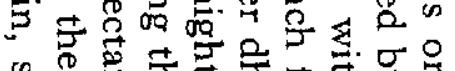
⿰

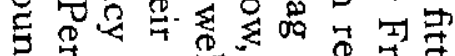

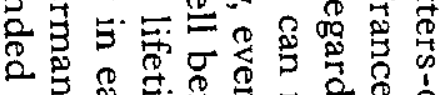

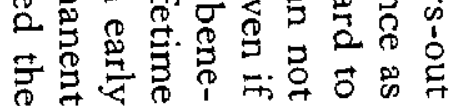




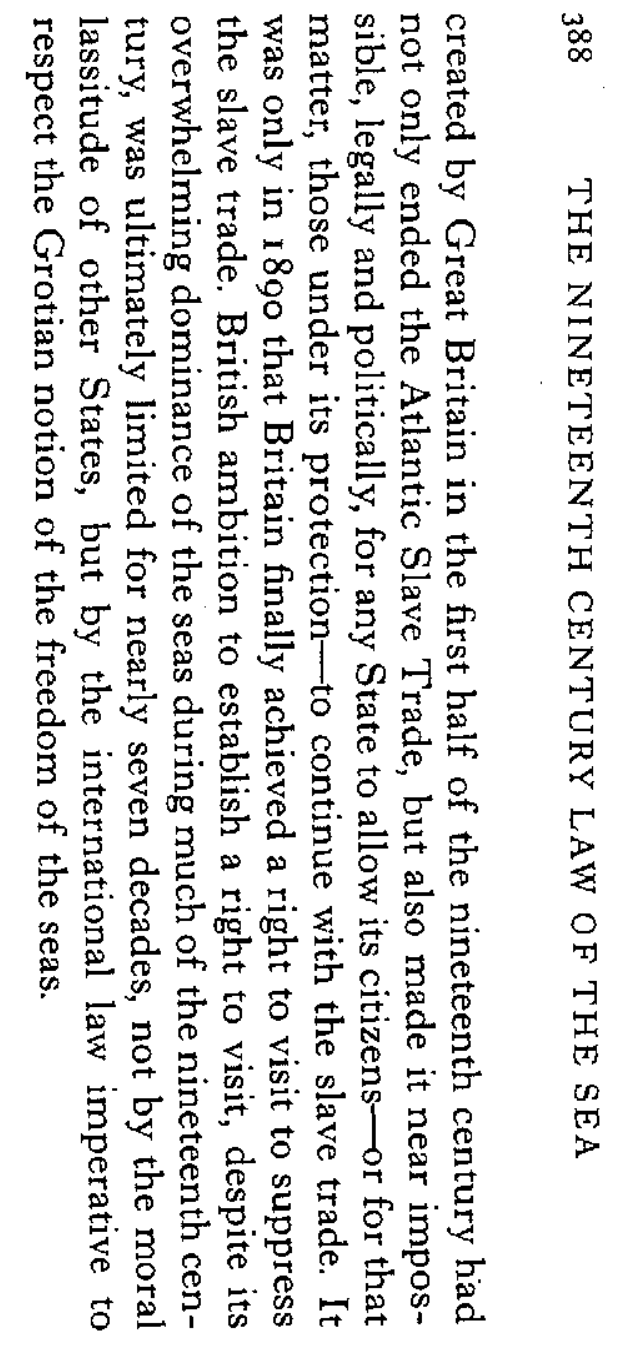


